
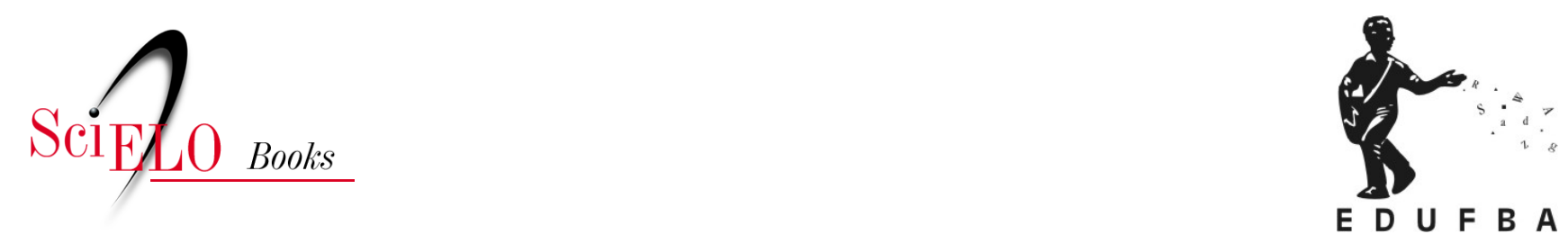

\title{
Política Nacional de Aids construção da resposta governamental à epidemia HIV/aids no Brasil
}

Sandra Garrido de Barros

\section{SciELO Books / SciELO Livros / SciELO Libros}

BARROS, S.G. Política Nacional de Aids: construção da resposta governamental à epidemia HIV/aids no Brasil [online]. Salvador: EDUFBA, 2018, 335 p. ISBN 978-85-232-2030-3.

https://doi.org/10.7476/9788523220303.

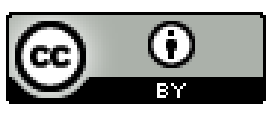

All the contents of this work, except where otherwise noted, is licensed under a Creative Commons Attribution 4.0 International license.

Todo o conteúdo deste trabalho, exceto quando houver ressalva, é publicado sob a licença Creative Commons Atribição 4.0. 
UNIVERSIDADE FEDERAL DA BAHIA

REITOR

João Carlos Salles Pires da Silva

VICE-REITOR

Paulo Cesar Miguez de Oliveira

ASSESSOR DO REITOR

Paulo Costa Lima

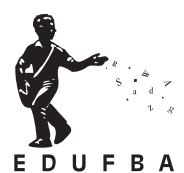

EDITORA DA UNIVERSIDADE FEDERAL DA BAHIA

DIRETORA

Flávia Goulart Mota Garcia Rosa

CONSELHOEDITORIAL

Alberto Brum Novaes

Angelo Szaniecki Perret Serpa

Caiuby Alves da Costa

Charbel Ninõ El-Hani

Cleise Furtado Mendes

Evelina de Carvalho Sá Hoisel

José Teixeira Cavalcante Filho

Maria do Carmo Soares de Freitas

Maria Vidal de Negreiros Camargo

Esta publicação contou com o apoio do CNPQ, Edital CNPq 41/2013, Processo n 405071/2013-2.

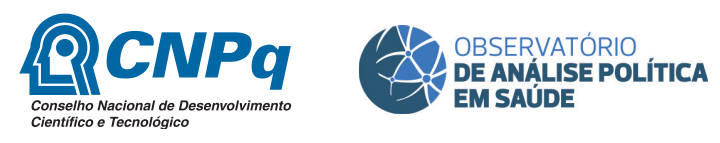


Sandra Garrido de Barros

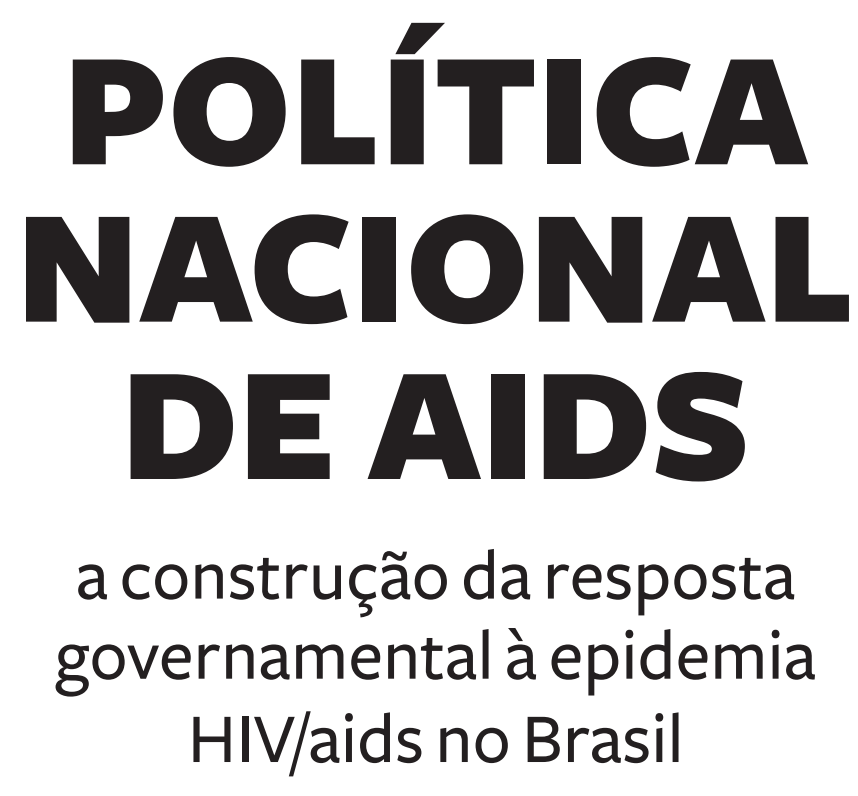

Salvador

EDUFBA

2018 
2018, Sandra Garrido de Barros.

Direitos para esta edição cedidos à EDUFBA.

Feito o depósito legal.

Grafia atualizada conforme o Acordo Ortográfico da Língua Portuguesa de 1990,

em vigor no Brasil desde 2009.

PROJETO GRÁFICO

Gabriela Nascimento

REVISÃO

Elber Lima

NORMALIZAÇÃO

Daiane Cruz de Azevedo

Sistemas de Bibliotecas/SIBI-UFBA

B277 Barros, Sandra Garrido de

Política Nacional de Aids: construção da resposta governamental à epidemia

HIV/aids no Brasil. Sandra Garrido de Barros. Salvador: Edufba, 2018.

335 p. il. cm.

ISBN: $978-85-232-1746-4$

1. AIDS (Doença) Brasil. 2. AIDS (Doença) x Prevenção. 3. AIDS (Doença) x Política de Saúde. 4. AIDS (Doença) x Estudo sócio-histórico. I. Título.

CDU 616.98:578.828(81)

Elaborada por: Gláucia M. N. Longo

Editora filiada à: $\underset{\text { ASOCIACION DE EDITORIALES }}{\text { UNIVERSITARIAS DE AMERICA }}$ LATINA Y EL CARIB

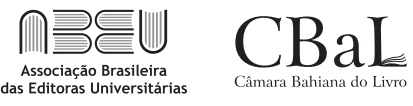

EDUFBA

Rua Barão de Jeremoabo, s/n Campus de Ondina

Salvador - Bahia CEP 40170-115 Tel: +55 (71) 3283-6164

www.edufba.ufba.br

edufba@ufba.br 
A todos que lutam pela construção de um sistema de saúde justo e universal. 


\section{Sumário}

Prefácio

A luta contra a aids: a originalidade do caso brasileiro

1 Respostas governamentais à epidemia da aids: situando a problemática e o objeto de pesquisa

2 Contribuições do referencial bourdieusiano e da abordagem sócio-histórica para a análise de políticas de saúde

Conceitos fundamentais

Análise da gênese de políticas de saúde

A conformação do espaço aids no Brasil (1981-1984) 48

$\begin{array}{ll}\text { Quem se interessava pela aids e por quê? } & 61\end{array}$

A resposta do Ministério da Saúde $\quad 70$

A aids, a $8^{a}$ Conferência Nacional de Saúde e a Assembleia Nacional 77

Constituinte

A construção de uma identidade: a saída da dermatologia sanitária 80

O isolamento do vírus no Brasil e as disputas do campo científico 93

O espaço militante $\quad 98$

Grupo de Apoio e Prevenção à Aids (Gapa) 98

Associação Brasileira Interdisciplinar de Aids (Abia) 104

Posições e disputas ao interior do espaço militante 108

Comissão Nacional de Aids: a construção do discurso oficial 111

O campo religioso e o controle da aids 116 
4 Evolução e consolidação da política nacional de luta contra a 123 aids (1990-2001)

Retrocessos e avanços do governo Collor 124

Da resposta samaritana à Pastoral da aids: a nova atuação da igreja 139

O papel do Banco Mundial na consolidação da política 141

Cnaids: nova relação de forças 154

O acesso universal aos ARV e o reconhecimento internacional 162

Transformações no espaço aids: quem passou a se interessar pela 181 aids e por quê?

5 Conclusões e considerações finais 193

$\begin{array}{ll}\text { Posfácio } & 205\end{array}$

Referências $\quad 211$

Apêndice A Percurso metodológico 239

Apêndice B Trajetórias dos principais agentes estudados 247

Apêndice C Concepções acerca do conceito de homens que fazem 311 sexo com homens

Apêndice D Concepções dos agentes acerca do significado dos 313 acordos de empréstimo junto ao Banco Mundial para a política nacional de controle da aids

Apêndice E Concepções sobre a Comissão Nacional de Aids $\quad 318$

Apêndice F Realização profissional ou militante 321

Anexo A Declaração dos direitos fundamentais do portador 325 de HIV/aids

Anexo B Projeto de lei $\mathrm{n}^{\circ}$ 158, de 1996

Anexo C Discurso do presidente Fernando Collor de Melo em 330 cadeia nacional de rádio e TV 


\section{Prefácio}

\section{A luta contra a aids: a originalidade do caso brasileiro}

Nesta obra, Sandra Garrido propõe uma análise sócio-histórica da luta contra a aids conduzida no Brasil no período de 1981-2001. Ela traça a evolução da resposta social à epidemia desde a ocorrência dos primeiros casos diagnosticados até a implementação pelos poderes públicos brasileiros de um programa ambicioso de acesso universal da população afetada pelo vírus aos tratamentos antirretrovirais - quimioterapia combinada antirretroviral e antiprotease. Programa que valeu ao Brasil ser apresentado como um modelo de política antiaids para países em desenvolvimento.

Quando no início do ano de 2009, Sandra Garrido se inscreveu no doutorado sob a orientação de Ligia Vieira da Silva, professora do Instituto de Saúde Coletiva da Universidade Federal da Bahia, com a proposta de trabalhar sobre a política brasileira de luta contra a aids, já existia uma abundante literatura internacional tratando das respostas sociais à epidemia. Diversos trabalhos, notadamente os mais antigos, a respeito dos países do mundo ocidental - Estados Unidos da América, países europeus. Isso porque esses foram os primeiros onde a doença adquiriu visibilidade social de um flagelo, despertando mobilizações sociais e, com isso, promovendo a criação de políticas públicas. Além disso, a proximidade social entre os meios científicos e a população homossexual, à época a mais afetada pela doença, levou muitos pesquisadores das ciências humanas e sociais a se engajarem "cientificamente", estudando os movimentos coletivos que se organizavam e as estratégias de luta que eles implementavam. Mas as questões colocadas pelo desenvolvimento da epidemia fora dos países do chamado "primeiro mundo", fomentaram, por sua vez, estudos que deram uma dimensão verdadeiramente internacional às pesquisas 
sobre "AIDS" nas ciências sociais e políticas - o que, em suma, é o caso apenas de um número limitado de doenças.

Ao familiarizar-se com uma produção científica, rica em diversidade das questões tratadas e ainda heterogêneas em suas abordagens, abrangendo toda a gama de níveis de análise, desde a microssociologia das pesquisas etnográficas até as grandes sínteses internacionais, Sandra Garrido compromete-se a definir o que será o objeto de sua pesquisa. É neste momento que, dado a uma série de seminários em Salvador, a conheci. Convidado pela professora Ligia Maria Vieira da Silva, como parte de um programa de cooperação com o Instituto de Saúde Coletiva, apresento os resultados de várias pesquisas sócio-históricas sobre políticas de saúde, uma das quais, realizada com uma equipe de pesquisadores parisienses, analisa o movimento de luta contra a aids na França desde sua emergência no início dos anos 1980 até os anos 1996, momento da implementação da triterapia. Nesta pesquisa, nós tratamos das relações complicadas - na França - entre as organizações que estruturavam o universo do homossexualismo parisiense e a primeira geração de associações “aids”. Estas, criadas por ex-militantes de grupos políticos da extrema esquerda pós-1968, recusavam uma abordagem homossexual comunitária da luta contra a aids - do tipo que havia se estabelecido nos países anglo-saxônicos -, pois para apoiar todos os doentes, uma causa deve mobilizar aqueles que se sentiam afetados direta ou indiretamente pela epidemia. Acompanhamos, em seguida, a evolução do movimento associativo, seu desenvolvimento ligado à nova visibilidade que os testes de soropositividade deram à epidemia, suas divisões, a diversificação de seus modos de intervenção, a aparição com Act-Up Paris de um pólo ativista radical, a dinâmica de relações interassociativas, colaboração e lutas de concorrência. Nós mostramos que essa evolução mantém relações de interdependência com as iniciativas tomadas pela burocracia da saúde pública e pelos sucessivos governos, notadamente durante a formulação e implementação de uma política de luta contra a aids, cuja viabilidade fundamentou-se em uma aliança entre as instituições de saúde pública, os médicos encarregados dos pacientes e o movimento associativo. Analisamos as consequências tanto nas instituições públicas com a criação de novas estruturas especializadas - agência 
nacional para a pesquisa contra a aids, agência francesa de luta contra a aids que se encarrega da prevenção etc. - quanto nas orientações das associações e na sua institucionalização ligada ao financiamento público, bem como ao pensamento de estado relativo às questões da toxicomania e da homossexualidade. Nas instituições públicas, houve uma relativização da lógica terapêutica baseada na abstinência, até então dominante, em benefício de uma lógica, que privilegiava a "redução de risco" da contaminação. Já nas associações, observou-se a implementação de uma política destinada a fomentar o desenvolvimento de estruturas de socialização para homossexuais, gays e lésbicas, além de proporcionar um quadro legal para o reconhecimento de casais homossexuais.

Sandra Garrido decide então se inspirar na nossa abordagem, e eu aceito com prazer coorientar sua tese - a obtenção de uma bolsa de estudo "sanduíche" lhe permitiu passar um ano na França em nosso laboratório. Assim, ela se diferenciará dos trabalhos que até então abordaram a questão da luta contra a aids no Brasil, focalizados na análise das respostas governamentais à epidemia e limitando o alcance do estudo a um período limitado ou a exemplos de políticas locais. Sandra Garrido almejava aproveitar a política brasileira a longo prazo para relatar suas diferentes fases desde as primeiras ações no estado de São Paulo - quando a doença ainda não tinha sido caracterizada como aids e que nada permitia prever a magnitude que a epidemia tomaria até o lançamento dessa política nacional que colocaria o Brasil na vanguarda da luta contra a aids nos países em desenvolvimento. Para realizar tal projeto, ela se apoia em um importante trabalho empírico, explorarando arquivos e coletando informações orais, da coleta e análise de inúmeros relatórios administrativos, do texto de leis, de "literatura cinza", e também de publicações de todos os tipos artigos de imprensa, textos de associações antiaids. Também entrevistas em profundidade com figuras históricas de militância associativa, de gestores e médicos que desempenharam papéis de liderança nas várias fases da luta contra a aids. Mas este trabalho empírico não é feito cegamente. Ele é guiado por uma problemática aberta que ajuda a enriquecê-lo, sugerindo novos caminhos. Sua perspectiva teórica, de início, a faz desenhar dois grandes princípios de análise. O primeiro interpreta a evolução da 
política de aids como sendo o produto de uma dinâmica social, ou seja, uma dinâmica que resulta da interpenetração das estratégias de agentes que compartilham o objetivo de lutar contra a epidemia, mas que, pertencendo a vários campos sociais - militantes de associações, médicos, membros da gestão, políticos etc. - ocupam posições diferentes e não têm a mesma visão do que deve ser a luta contra a aids, nem os mesmos interesses a defender. O segundo, inspirado pela teoria de campo de Pierre Bourdieu, se propõe a analisar os discursos e as práticas da luta contra a aids como produções de um espaço social específico na interface dos diferentes campos, aos quais pertenciam os agentes envolvidos nessa luta. Sabendo que este espaço é ao mesmo tempo o terreno de colaboração entre esses agentes e de luta de concorrência, na qual o que está em jogo é a definição da (boa) política de luta contra a aids e os meios de sua implementação.

Sandra Garrido se empenha então em reconstruir a gênese de um "espaço aids brasileiro" com suas próprias especificidades e as transformações que ele experimentará ao longo de sua história, colocando tudo na história dos diferentes campos - médico, associativo, burocrático religioso e político - envolvidos, de uma forma ou de outra, por alguns de seus agentes na luta contra a epidemia. Isso para entender quais poderiam ser os interesses próprios de um médico, um voluntário associativo, um político etc., de investir em um dado momento na luta contra a aids. E ela vai fazê-lo de uma forma muito "profissional”. Nada na obra que nos é dada para ler sugere que sua formação universitária não a preparou para esse trabalho, ela se apropriou no próprio momento de sua pesquisa, e de uma forma muito notável das ferramentas conceituais da sociologia, e particularmente as desenvolvidas por Pierre Bourdieu - campo, habitus, capital simbólico, capital social etc. Muitas foram as discussões que tivemos durante a sua estadia no Centro Europeu de Sociologia e Ciência Política, das quais não só mantive a memória do seu entusiasmo e da sua capacidade de reflexão, questionamento, além a sua compreensão dos conceitos à luz dos problemas que encontrava ao analisar seu material.

Mais algumas linhas para apresentar o que eu acho que são as principais características da obra. Sandra Garrido nos mostra as semelhanças 
que a luta contra a aids no Brasil apresenta com o que aconteceu em muitos países. Assim, ela está estruturada, como na maioria dos países ocidentais, por uma aliança - às vezes conflituosa - entre militantes de organizações não governamentais, os médicos e os agentes da gestão de saúde pública envolvidos seja na pesquisa, seja no suporte médico e social dos doentes ou nas campanhas de prevenção e de triagem. Essa aliança tripla está ligada a uma especificidade histórica da epidemia de aids encontrada no Brasil, como em outros lugares, a saber, a existência de uma fase inicial em que a epidemia ainda parece de baixa intensidade, circunscrita a grupos sociais marginais, predispostos à estigmatização, nos quais a doença rapidamente se mostra letal e insensível ao tratamento. Apenas a prevenção pode permitir um controle da epidemia. De fato, nessa fase em que a prevenção é o principal recurso, a colaboração de médicos e das autoridades administrativas com os primeiros militantes associativos, homossexuais na sua maior parte, aparece como uma condição necessária para uma intervenção preventiva direcionada à população mais ameaçada pela epidemia e que, para ser eficaz, deve evitar qualquer forma de estigmatização. Garrido confirma o fato de que essa colaboração está condicionada à existência de formas pré-existentes de organização do meio "gay", como é o caso na cidade de São Paulo, onde a primeira política de luta contra a aids foi iniciada por uma reunião entre um grupo de militantes que lutam pelos direitos dos homossexuais e representantes da Secretaria Estadual de Saúde. O livro também destaca que no Brasil, como na França ou nos EUA, a dinâmica da mobilização associativa evolui em relação às mudanças na representação da epidemia que aparecem com a chegada no mercado dos testes diagnósticos revelando a amplitude da contaminação por HIV e, depois, novamente com a descoberta de métodos eficazes de tratamento.

Mas é o destaque das especificidades da luta contra a aids no Brasil que dá a este livro todo o seu interesse em trazer novos elementos que enriquecem a dimensão comparativa fundamental para qualquer reflexão sociológica. Essas especificidades não refletem as peculiaridades dos movimentos homossexuais e associativos, mas a conjunção própria à história brasileira, entre a ocorrência da epidemia e o desenvolvimento do 
movimento para a reforma sanitária, nascida sob a ditadura militar e que, com o retorno à democracia, será atualizada em uma reorganização do sistema de saúde. Em outras palavras, e isso é o que Sandra Garrido nos mostra, as formas tomadas pela luta contra a aids no Brasil que dependem da relação entre médicos, gestão e associações, serão, em grande medida, determinadas pelas questões da Reforma Sanitária. Por conseguinte, ao contrário da França, por exemplo, observa-se o papel pioneiro da gestão da saúde no nascimento do movimento e a posição dominante durante todo o processo. Nós vemos da mesma forma como a importância das questões políticas relacionadas ao sistema de saúde, desde a sua reorganização, é o que favorece o distanciamento do governo vis-à-vis das diretrizes preconizadas pelo Banco Mundial sobre a proteção da propriedade intelectual de empresas farmacêuticas multinacionais e o que impulsiona a adoção de uma política de acesso universal a tratamentos retrovirais. Assim, se a epidemia não é a causa mais importante da mortalidade no país, os objetivos conferidos à luta contra a aids o fazem um caso exemplar de intervenção, concretizando as ambições da Reforma Sanitária. Este caso é ainda mais exemplar, porque é acompanhado por uma luta internacional contra os trustes farmacêuticos, tendo como consequência uma modificação das regras do jogo estabelecidas pela Organização Mundial do Comércio (OMC). Entendemos nessas condições porque, enquanto que em muitos países, a chegada de tratamentos eficazes ajuda a "normalizar" a luta contra a aids e é acompanhada por uma forte desmobilização do movimento associativo, o desafio do acesso universal ao tratamento, pelo contrário, estimulará o crescimento desse movimento no Brasil.

Um livro que é um marco para qualquer pessoa interessada na luta contra a aids, pela sociologia e pela política de saúde.

\section{Patrice Pinell}

Paris, 3 de maio de 2017. 



\section{Respostas governamentais à epidemia da aids: situando a problemática e o objeto da pesquisa}

A resposta à epidemia da aids ${ }^{1}$ no mundo teve início em um momento em que o saber médico ainda não tinha uma resposta terapêutica eficaz (PINELL et al., 2002)2002, de modo que se observava internacionalmente uma variedade de respostas governamentais determinadas, dentre outros fatores, pelo momento de identificação dos primeiros casos, pela percepção da doença em cada sociedade - quem é acometido, quantas pessoas, quais danos causados pela epidemia, natureza da disseminação dos casos -, pelo perfil epidemiológico, pelas condições políticas e econômicas de cada país e pelo estágio do desenvolvimento do conhecimento médico acerca da doença, como pode ser identificado nos estudos acerca da resposta governamental em países como Cuba (ARAZOZA et al., 2007; PÉREZ-STABLE, 1991, 1992), França (PINELL et al., 2002), China (WU et al., 2007; WU; ROU; CUI, 2004), Tailândia (AINSWORTH; BEYRER; SOUCAT, 2003), Paquistão (RAI et al., 2007), Bangladesh (AZIM et al., 2008), Suíça (VOEGTLI, 2009), Camarões (BOYER et al., 2011) e Brasil. (GALVÃO, 2000; GUERRA, 1993; MARQUES, 2003)

Poucos países anteciparam a resposta governamental aos primeiros casos de aids, como Cuba, que em 1983 instituiu as primeiras medidas para o controle da epidemia e teve o primeiro caso identificado em dezembro

No desenvolvimento do texto, optou-se por utilizar a palavra aids grafada em letras minúsculas. Apesar de ter origem na sigla AIDS, da expressão em inglês Acquired Immune Deficiency Syndrome, na língua portuguesa, siglas com quatro ou mais letras devem ser escritas apenas com a inicial maiúscula, quando formam uma palavra pronunciável. Mas, pelo seu uso, o termo aids terminou adquirindo a condição de substantivo, como nome de doença, devendo ser grafado apenas com letras minúsculas. 
de 1985 entre homossexuais; e Bangladesh, que desde 1985já havia instituído um Comitê Nacional de Aids, mas que só teve registro de casos a partir de 1989. (ARAZOZA et al., 2007; AZIM et al., 2008) Na maioria dos países, o desenvolvimento de uma política visando o controle da epidemia da aids aconteceu após a identificação dos primeiros casos no país, sendo que em alguns deles, como na França (PINELL et al., 2002), na Suíça (VOEGTLI, 2009) e no Brasil (GALVÃO, 2000; GUERRA, 1993; MARQUES, 2003), por exemplo, com importante participação de movimentos sociais e a constituição de associações específicas de luta contra a aids desde a década de 1980, enquanto em outros países essa articulação entre governo e organizações não governamentais ocorreu principalmente na década de 1990, com indução governamental, como em Bangladesh (AZIM et al., 2008) e na Tailândia. (AINSWORTH; BEYRER; SOUCAT, 2003)

Alguns países, como Cuba, Tailândia e Suíça, responderam inicialmente através de ações de controle, a exemplo da testagem massiva para identificação de casos e isolamento de soropositivos. (AINSWORTH; BEYRER; SOUCAT, 2003; ARAZOZA et al., 2007; PÉREZ-STABLE, 1991, 1992; VOEGTLI, 2009)

No Brasil, na resposta inicial à epidemia, prevaleceram estratégias com ênfase na promoção da saúde e prevenção, como educação em saúde e estímulo ao uso de preservativos. (GALVÃO, 2000; GUERRA, 1993; PIOT; SECK, 2001) A partir de 1989 essas estratégias foram associadas ao fornecimento de zidovudina (AZT) no estado de São Paulo, e em 1991 pelo Ministério da Saúde. (PROGRAMA NACIONAL DE DST E AIDS, 2005) A associação de ações de promoção da saúde e prevenção da doença à oferta de medicamentos também foi o caminho adotado em países onde a doença se manifestou mais tardiamente, como na China, Paquistão e Camarões, por exemplo. (BOYER et al., 2011; RAI et al., 2007; WU et al., 2007)

As notícias acerca da nova doença chegaram antes da identificação dos primeiros casos de aids no país, através da imprensa, que além da influência na sua divulgação, no alerta ao seu surgimento e no despertar do interesse de profissionais de saúde e grupos sociais, que começaram a se mobilizar, também disseminou metáforas que contribuíram para criar um comportamento de preconceito, medo, moralismo, pânico e 
até mesmo de indiferença, como se esse fosse um problema estrangeiro. (MARQUES, 2003) A nova doença era denominada por nomes como “doença dos homossexuais”, "câncer gay”, "praga gay”, "peste gay”. (GALVÃO, 2000; MARQUES, 2003)

Os primeiros casos foram identificados na cidade de São Paulo, a partir de 1982,² e em meados de 1983, a Secretaria de Saúde do Estado já estava implantando o primeiro programa governamental de luta contra a aids no país. (FRANÇA, 2008; GALVÃO, 2000; GUERRA, 1993; MARQUES, 2003) No âmbito nacional, apenas a partir de 1985, a aids entrou na agenda política do Ministério da Saúde. (BRASIL, 1985b; GALVÃO, 2000)

Os princípios de universalidade do acesso, integralidade das ações e participação social propostos pelo movimento da Reforma Sanitária Brasileira e inseridos na Constituição Federal de 1988 orientaram a formulação e implantação da resposta brasileira à epidemia. (GRANGEIRO; SILVA; TEIXEIRA, 2009; MALTA; BASTOS, 2008) Desde 1991, o programa nacional passou a fornecer AZT para pessoas vivendo com HIV/aids. A partir de 1996, a distribuição universal de antirretrovirais (ARV), estratégia do programa nacional reconhecida internacionalmente, foi incorporada à política brasileira. Entre outros fatores, em decorrência da pressão social exercida pelos inúmeros processos judiciais propostos por pessoas vivendo com HIV/aids, contra as três esferas do governo, para ter acesso à terapia ARV através do Sistema Único de Saúde. (GALVÃO, 2000; MALTA; BASTOS, 2008; PROGRAMA NACIONAL DE DST E AIDS, 2005)

Entre 1980 e junho de 2015, foram registrados no país 798.366 casos de aids. ${ }^{3}$ (BOLETIM..., 2015) Nos primeiros anos, a epidemia atingiu os homossexuais masculinos dos grandes centros urbanos da região Sudeste, principalmente São Paulo, posteriormente difundindo-se para todos os estados e para a população em geral, e nos estratos sociais de

2 Um caso foi registrado retrospectivamente como ocorrido em 1980. (TEIXEIRA, 1997)

3 Casos notificados no Sistema de Informações sobre Agravos de Notificação Compulsória (Sinan) e registrados no Sistema de Controle de Exames Laboratoriais (Siscel) e no Sistema de Controle Logístico de medicamentos (Sisclom) até 30/06/2015 e declarados no Sistema de Informações de Mortalidade (SIM) de 2000 a 2010, dados preliminares para os últimos cinco anos. 
maior nível de escolaridade. (BASTOS; BARCELLOS, 1995; FONSECA; SZWARCWALD; BASTOS, 2002; SZWARCWALD et al., 2000)

A estimativa de prevalência de HIV/aids, em indivíduos de 15 a 49 anos, tem se mantido estável em 0,6\% desde 2004- - ,4\% entre as mulheres e $0,7 \%$ entre os homens (BOLETIM..., 2014), ficando bem abaixo da expectativa do Banco Mundial para o ano 2000 no momento da implantação do primeiro acordo de empréstimo, que previa 1.200.000 brasileiros infectados. (THE WORLD BANK, 1993) A taxa de incidência encontra-se estabilizada no país desde 2000, tendo sido de 17,9 por 100.000 habitantes em 2010. (BOLETIM..., 2011; SZWARCWALD et al., 2000)

A tendência à estabilização da epidemia teve início em 1997, coincidindo com a introdução da terapia antirretroviral universal no país. (DOURADO et al., 2006) Desde 1996, a distribuição gratuita e universal de medicamentos constituiu-se em componente central do programa nacional, a despeito do fato de que o Banco Mundial, principal agência financiadora das políticas de HIV/aids no mundo, priorizava a prevenção em detrimento de gastos com assistência e tratamento considerados caros, em especial nos países em desenvolvimento. (GALVÃO, 2000; MALTA; BASTOS, 2008; OISG, 2008; THE WORLD BANK, 1993)

Entre 1980 e 2010 , ocorreram alterações na participação das categorias de exposição à doença. Se no início da epidemia prevalecia a categoria de homens que fazem sexo com homens (homo e bissexuais), seguida pelos hemofílicos e receptores de sangue ou hemoderivados, a partir de 1989 observou-se um aumento da participação das subcategorias usuários de drogas injetáveis (UDI) e transmissão heterossexual. (BOLETIM..., 2001)

Entre 1991 e 1993, os UDI passaram a ser a categoria predominante, sendo que, a partir de 1994, a principal categoria de exposição passou a ser a heterossexual (BOLETIM..., 2001), levando também a um maior acometimento do sexo feminino. (BASTOS; BARCELLOS, 1995) Assim, a razão de sexo (M:F) que era de 40:1 em 1983, a partir de 2002, estabilizou-se em 1,5:1. (BOLETIM..., 2009) Desde 2000, a epidemia passou a ser classificada como estabilizada e concentrada em populações de maior vulnerabilidade. (BOLETIM..., 2011) 
A preocupação com a oferta de medicamentos, desde o final da primeira década de implantação, aponta para uma especificidade da política brasileira: a incorporação da diretriz da integralidade da atenção, que busca articular prevenção e tratamento. Característica esta que, associada ao enfrentamento dos preços impostos pela indústria farmacêutica, contribuiu também para a implantação dos medicamentos genéricos no Brasil. (LOYOLA, 2008; RODRIGUES; SOLER, 2009)

Nesse sentido, o Brasil assumiu importante papel na luta pela redução dos preços dos medicamentos ARV, evidenciada pela disputa entre 2000 e 2001 no âmbito da Organização Mundial do Comércio (OMC) com os Estados Unidos da América pela questão da licença compulsória de medicamentos e mais recentemente, em 2007, pela efetivação da licença compulsória do efavirenz. (LOYOLA, 2008; RODRIGUES; SOLER, 2009)

O Programa Nacional de DST/Aids tem sido considerado como de bom desempenho e impacto sobre indicadores de morbimortalidade, ainda que apresente limitações no que tange à manutenção e controle do estoque de medicamentos, infraestrutura dos serviços, treinamento adequado para profissionais de saúde, além das questões relacionadas ao financiamento. (MALTA; BASTOS, 2008; PIOT; SECK, 2001) Principalmente em função dos resultados obtidos com a distribuição universal de ARV (HACKER et al., 2004; OLIVEIRA-CRUZ; KOWALSKI; MCPAKE, 2004), a política brasileira de controle da epidemia de aids tem sido citada como modelo não apenas para outros países em desenvolvimento como Costa Rica, El Salvador, Panamá (PIOT; SECK, 2001) e China (WU et al., 2007), mas também para os próprios Estados Unidos da América (EUA). (GÓMEZ, 2008, 2010; NUNN, 2009) Podem ser citados como exemplos de iniciativas que sofreram influência da estratégia brasileira:

- o President's Emergency Plan for AIDS Relief (PEPFAR), ${ }^{4}$ através do qual os EUA fornecem medicamentos para aids para países africanos e caribenhos;

4 Iniciativa do governo norte-americano para reduzir o sofrimento das pessoas vivendo com HIV/aids no mundo que teve início em 2003, cujo um dos objetivos é expandir prevenção, cuidado e tratamento. (PEPFAR, 2012) 
- a iniciativa 3 by $5^{5}$ da Organização Mundial de Saúde (OMS), que previa um incremento de 3 milhões de pessoas fazendo uso de ARV no final de 2005. (OKIE, 2006)

O interesse internacional pela política brasileira de controle da aids pode ser evidenciado através de artigos e estudos publicados na literatura internacional por pesquisadores estrangeiros, descrevendo o desenvolvimento da estratégia nacional, inclusive em comparação com a política norte-americana e enfatizando não apenas a estratégia de acesso universal aos medicamentos ARV, mas também as estratégias de prevenção adotadas pelo Programa Nacional. (GÓMEZ, 2008, 2010; NUNN, 2009; OKIE, 2006)

Estudos que tratam da resposta à epidemia e da gênese da política têm dado ênfase à análise da participação das organizações não governamentais (ONGs) na luta contra a aids no país ou da sua relação com o Estado, sempre colocando o campo burocrático em um segundo plano. (CAMPOS, 2005; GALVÃO, 2000; MONTEIRO, 2006; SILVA, 1999) Aqueles que fizeram uma análise mais centrada na resposta governamental à epidemia também não estenderam a sua análise à participação do campo médico e científico. (GÓMEZ, 2008; MARQUES, 2003; NUNN, 2009) Além disso, outras investigações têm valorizado principalmente o processo de implementação da política estatal, tratando de períodos, contextos ou aspectos mais específicos, analisando os processos de formulação e desenvolvimento da política no estado de São Paulo, para usuários de drogas injetáveis, acerca da descentralização da política, ou realizando estudos do grau de implantação da política em unidades federativas e acerca da institucionalização do programa em municípios. (BARBOZA, 2006; FONSECA, 2008; FRANÇA, 2008; GUERRA, 1993; LIMA, 2006; SANTOS, 2009; STANISE, 2008)

Na França, Pinell e colaboradores (2002) operacionalizando o conceito de espaço social, estudaram o universo de possíveis para a emergência de um movimento de luta contra a aids naquele país, assim como a estrutura e a dinâmica de relações dos agentes engajados no espaço aids medicamentos ARV a 3 milhões de pessoas vivendo com HIV/Aids até 2005. (WHO, 2012) 
no período de 1981 a 1996. O espaço associativo aids na França surgiu com a mobilização popular frente a lacunas e incoerências das medidas governamentais para o enfrentamento da epidemia, ou seja, buscando substituir as instituições estatais para cumprir uma função pública. A luta contra a aids, ao contrário do combate a outras doenças como câncer e a tuberculose, também estudadas por Pinell (2010), assumiu, assim, características de contestação social, estruturada por associações militantes. A criação de associações específicas de luta contra a aids foi anterior à resposta governamental e teve como principais agentes militantes homossexuais, sendo que aquele espaço associativo conformou-se com uma autonomia relativa em relação ao campo homossexual, o que permitiu um alargamento da base do movimento e a abertura de serviços aos demais grupos atingidos pela epidemia. A partir da atuação dessas associações, dos avanços no campo médico e da evolução da representação da doença - que passou a atingir a população geral - pela sociedade francesa, foi formulada a política de luta contra a aids daquele país, provocando modificações importantes em áreas como a homossexualidade e a toxicomania, considerando a sua associação com a epidemia.

No Brasil foi localizado apenas um trabalho que buscou articular a posição ocupada no "campo de políticas públicas em HIV/aids” ou no “campo do HIV/aids" e as formas de ação empreendedora, ${ }^{6}$ baseado no conceito de campo proposto por Bourdieu. (MENDONÇA; ALVES; CAMPOS, 2010) O estudo considerou o grupo de médicos que assumiu posições importantes no programa nacional, em especial os de São Paulo, e as organizações não governamentais como empreendedoras institucionais, sendo as últimas empreendedoras desafiantes por ocuparem uma posição periférica, além de terem importante papel na manutenção da legitimidade do tema fora do "campo do HIV/aids" (empreendedorismo extrainstitucional). A análise de Mendonça, Alves e Campos (2010) concentrou-se especialmente no campo médico e nas associações específicas de luta contra a aids, considerando outsiders a população geral e as demais áreas

6 Otrabalho desenvolvido por Mendonça, Alves e Campos (2010) teve como principal referencial a teoria organizacional neo-institucionalista. 
do setor saúde; o campo científico e o campo burocrático. Além disso, o estudo também não explorou a potencialidade de análise do referencial bourdieusiano, principalmente na interação entre trajetória dos agentes e as condições históricas de possibilidade.

Nesse sentido, entende-se que o conceito de espaço aids, sugerido por Pinell e colaboradores (2002), mostra-se mais adequado que o de campo, haja vista tratar-se de um espaço de relações entre agentes envolvidos com a organização da resposta à epidemia da aids, ainda que tenha contribuído para a constituição de um movimento associativo específico ao seu interior, dependente do conhecimento médico acerca da doença - definição das causas, descoberta de testes diagnósticos, possibilidades terapêuticas - para seu desenvolvimento. Ou seja, o espaço aids tem uma relação de dependência, em especial com o campo médico, não podendo ser compreendido como um campo que possui autonomia relativa, conforme proposto por Bourdieu.

Os estudos revisados concentraram-se na análise de casos de unidades federativas, em especial São Paulo, ou em uma abordagem nacional centrada na relação entre ONGs e Estado, seja destacando a atuação política dessas organizações, seja enfatizando a formulação e implantação da política pública nos diferentes níveis do sistema de saúde. Os referidos trabalhos não têm analisado de forma mais sistemática a interação entre os agentes dos diferentes subespaços envolvidos na resposta à epidemia da aids no país, seus pontos de vista sobre a epidemia e as estratégias adotadas na emergência do espaço aids e na formulação e consolidação da política específica de luta contra a doença no país. Dessa forma, diversas perguntas não estão respondidas nas investigações revisadas:

- Por que foi formulada uma política para o controle da aids logo após a sua descoberta, quando não havia evidências sobre a sua magnitude e vulnerabilidade?

- Como e quando se desenvolveu no Brasil uma política de controle da aids baseada não apenas na prevenção, mas também no tratamento (doenças oportunistas e, mais tarde, acesso a ARV)? 
- Como se organizou o espaço aids no Brasil? Qual a sua composição? Quem são seus agentes? O que estava em disputa? Por que as pessoas interessaram-se pela luta contra a aids? Qual o impacto sobre o movimento homossexual? Quais os interesses de cada subespaço específico? Quais as relações de poder estabelecidas?

- Qual a relação das ações de luta contra a aids e o movimento pela Reforma Sanitária brasileira?

À medida que a história avança, o espaço de possíveis realizáveis se fecha, porque as alternativas iniciais de onde saíram as escolhas historicamente construídas são esquecidas, o que Bourdieu (2012, tradução nossa) denominou "amnésia da gênese". As escolhas e decisões tornamse constrangimentos objetivados nas instituições, e interiorizados e incorporados pelos agentes. De modo que, para este autor, a análise sócio -histórica, além de identificar os agentes e disputas iniciais, pode revelar os possíveis não realizados, mortos e esquecidos, afastando-nos da tendência em aceitar que o ocorrido era o que deveria ter acontecido. O estudo da gênese, então, é uma importante estratégia de ruptura com o senso comum e a análise, a partir do referencial teórico bourdieusiano, permite a articulação entre estruturas objetivas e mentais, internas e externas, e as trajetórias dos agentes envolvidos, buscando uma integração entre o material e o simbólico.

O estudo da gênese e consolidação da política nacional de controle da aids no Brasil, como caso exemplar do possível, apoiado nesse referencial teórico, pode fornecer elementos para a resposta a algumas dessas indagações, a partir da análise das condições históricas que contribuíram para a constituição do espaço aids no país e da trajetória social e profissional de participantes desse processo. Nesse sentido, foram realizadas 31 entrevistas em profundidade com agentes envolvidos na luta pela resposta à epidemia da aids no Brasil, ocupando diferentes posições no interior do espaço aids, em diversos momentos históricos, além de uma consulta por e-mail, bem como análise de documentos do Ministério da Saúde, de organizações não governamentais e reportagens veiculadas na mídia impressa. ${ }^{7}$

7 O desenho do estudo encontra-se detalhado nos Apêndices A a C. 
O resultado desse estudo mostra que, no Brasil, o fato de a gênese da política de controle da aids ter ocorrido durante um momento de ascensão do movimento sanitário e na ausência de uma terapia específica, pode ter resultado na priorização inicial da prevenção, mas sempre sob a dominância do campo médico, levando, a partir da década de 1990, à ênfase na universalização do tratamento. $O$ fato de ter inicialmente atingido um grupo organizado, como os homossexuais, e com lideranças com alto volume de capital cultural e social, portanto com uma importante rede de contatos, contribuiu para uma resposta precoce por parte do Estado brasileiro, quando ainda não havia evidências epidemiológicas da magnitude e vulnerabilidade da doença no país.

A emergência dessa política durante o período de redemocratização, com a formação de várias organizações não governamentais, e a constituição do Sistema Único de Saúde, quando agentes do movimento sanitário assumiram importantes funções nos diferentes níveis da gestão do sistema de saúde brasileiro, bem como a dominância do campo médico podem ter contribuído para a formulação de uma política baseada na integralidade das ações e no acesso universal à assistência, como podem ter possibilitado uma maior participação da burocracia estatal na sua formulação.

Isso foi possível de ser verificado a partir da análise da gênese e consolidação da política nacional de controle da aids no Brasil, no período compreendido entre 1981 e 2001, bem como das trajetórias dos agentes envolvidos com a formulação e implantação dessa política, das relações estabelecidas entre esses agentes com o espaço da saúde coletiva, o movimento da reforma sanitária brasileira, o campo médico e o campo do poder. Também foram analisadas as condições de possibilidade históricas e o universo de possíveis que permitiram a formulação de uma política baseada na integralidade e na universalidade da atenção à saúde. 



\section{Contribuições do referencial bourdieusiano e da abordagem sócio-histórica para a análise de políticas de saúde}

Para reconstruir a dinâmica do jogo social, do qual emergiram as respostas à epidemia da aids no Brasil, foi adotado o referencial teórico da sociologia reflexiva de Bourdieu (1996, 2001, 2008), apoiado na proposta de Pinell e colaboradores (2002) e Pinell (2010) para a análise sociológica de políticas públicas.

\section{Conceitos fundamentais}

O conceito de espaço social foi adotado para estudar a estrutura e a dinâmica de relações dos agentes engajados em lutas concorrentes em torno de um objetivo comum (PINELL et al., 2002), no caso específico desse estudo, a luta contra a epidemia da aids. O espaço aids foi analisado a partir da compreensão do seu processo de emergência, desenvolvimento e transformação.

A ideia de diferença está no fundamento do conceito de "espaço social”. A distribuição dos agentes no espaço social se dá de acordo com as diversas espécies de capital e em particular com o "capital cultural”, “o capital econômico", “o volume de capital global” e a "trajetória social”, mas também com os capitais político, social, simbólico e mesmo o capital burocrático. As diferenças entre essas posições correspondem a diferenças nas disposições (habitus) ${ }^{8}$ e nas tomadas de posição. Ou seja, a cada

8 Habitus é o princípio gerador e unificador das práticas. Representa as características intrínsecas e relacionais de uma posição em um estilo de vida (escolhas de pessoas, bens e práticas), gerando práticas distintas e distintivas. É o senso prático do que se deve fazer em uma 
classe de posições corresponde a uma classe de habitus - ou de gostos produzidos pelos condicionamentos sociais associados à condição correspondente e, pela intermediação desses habitus e de suas capacidades geradoras. (BOURDIEU, 1996)

O capital cultural é constituído por um conjunto de bens simbólicos relacionados aos conhecimentos incorporados - ser competente em um domínio do saber, ser culto, ter bom domínio da linguagem -, à posse de bens culturais - livros, dicionários, instrumentos, máquinas - e, no seu estado institucionalizado, aos títulos, diplomas e à aprovação em concursos, que nada mais são que a objetivação do reconhecimento de competências pelo Estado. O capital cultural é resultado de um trabalho contínuo de aprendizagem e acumulação. Sua aquisição demanda tempo e, portanto, bens materiais, geralmente estando relacionado com o capital econômico do qual seria uma espécie de conversão. Assim, o capital cultural é constituído a partir da interação entre os espaços familiar e escolar, de modo que agentes com o mesmo capital escolar podem possuir capitais culturais diferentes em função do seu capital cultural herdado. (BOURDIEU, 2008)

O capital social é um capital de relações, trata-se dos ganhos associados à existência de uma rede de conexões atuais ou potenciais, mais ou menos institucionalizadas, de pertencimento a um grupo. O capital social tende a ser uma espécie de multiplicador de seus poderes por um efeito de agregação simbólica. (BOURDIEU, 1980)

O capital simbólico é uma forma de capital que nasce da relação entre uma espécie qualquer de capital e os agentes socializados de maneira a conhecer e reconhecer essa espécie de capital. Para Bourdieu (2012), mesmo nos casos em que a espécie de capital é mais próxima do mundo físico, não há efeito físico que não se acompanhe de efeito simbólico, de modo que o conceito de capital simbólico permite fazer uma teoria materialista do simbólico. Nesse sentido, o capital econômico não se trata apenas da riqueza. Há um reconhecimento relacionado à riqueza que faz

dada situação. Corresponde às disposições dos agentes, seus esquemas de percepção, produzidos pela história coletiva, modificados pela história individual de cada um, e incorporados de forma inconsciente. (BOURDIEU, 1996, 2008) 
com que a força econômica exerça também um efeito simbólico além da riqueza dada pelo reconhecimento.

O capital simbólico é uma propriedade qualquer (de qualquer tipo de capital, físico, econômico, cultural, social), percebida pelos agentes sociais em cujas categorias de percepção são tais que eles podem entendê-las (percebê-las) e reconhecê-las, atribuindo-lhes valor. (BOURDIEU, 1996, p. 107)

É portanto, a forma como qualquer tipo de capital é percebido pelos agentes do espaço social.

O capital político está relacionado à capacidade de mobilização de um agente, é uma espécie de capital social e simbólico, obtido a título pessoal, resultado de um capital pessoal de notoriedade e popularidade - ser conhecido e reconhecido -, ou por delegação de uma organização detentora desse tipo de capital, como partidos ou sindicatos. À medida que a política profissionaliza-se, a luta é reservada aos profissionais e às grandes unidades de produção e difusão, excluindo os "profanos”, de modo que a objetivação do capital político foi realizada a partir do acesso a posições na política tradicional, ou seja, em postos no seio de um partido e nos organismos de poder e em toda a rede de empresas em simbiose com esses organismos, bem como na participação em cargos eletivos. (BOURDIEU, 2001; MATONTI; POUPEAU, 2004)

O capital militante cobre um conjunto de saberes e práticas, mobilizados durante as ações coletivas, as lutas inter ou intrapartidárias, é incorporado sob a forma de técnicas, de disposições de agir, intervir ou simplesmente obedecer. Este capital é passível de ser convertido em outros universos, podendo facilitar certas reconversões capazes de manter ou transformar a posição de um indivíduo ou de um grupo na estrutura social. (MATONTI; POUPEAU, 2004) Sob certas condições, o capital militante pode ser uma via de acesso ao capital político, quando, por exemplo, um agente é associado a personificação e divulgação de uma ação que permite reconverter sua notoriedade militante adquirida em investimentos políticos mais institucionalizados, como os partidos políticos. (GARCIA, 2005) 
No espaço social, podem ser identificados subespaços constituídos por redes de relações entre agentes e instituições com leis próprias, autonomia relativa e um habitus comum, no qual existem lutas específicas que fazem sentido aos seus integrantes, ao que Bourdieu denomina “campo".

O espaço aids foi considerado um espaço onde se articulam agentes - dos campos médico, científico, burocrático, político e do espaço associativo ou militante ${ }^{9}$ - engajados na luta pela organização da resposta à epidemia da aids. (PINELL et al., 2002)

Para a análise do espaço associativo ou militante, foi adotado o modelo de análise dos movimentos sociais em saúde proposto por Brown e colaboradores (2004) a partir da teoria dos movimentos sociais, dividindo-os em três categorias: movimentos de acesso à saúde, que lutam por acesso equânime à assistência médica e para a implementação da oferta de serviços de assistência à saúde, movimentos de saúde circunscritos a grupos específicos, direcionados à luta contra as desigualdades em saúde baseadas em raça, etnia, gênero, classe e/ou diferenças sexuais, e movimentos desaúde incorporados, que se direcionam para a doença, desafiando a ciência em relação a etiologia, diagnóstico, tratamento e prevenção.

A Saúde Coletiva, no momento da sua gênese, foi compreendida enquanto um espaço social influenciado de forma importante pelo saber e práticas do campo médico - do qual surgiu e no qual seus agentes ainda guardam raízes e identidades -, mas em busca de autonomia e identidade própria, cuja institucionalização se dá no âmbito dos campos científico e burocrático, além da relação estreita com os campos político e do poder, tendo como projeto político a Reforma Sanitária. (VIEIRA-DA-SILVA;

Os agentes pertencentes às associações específicas de luta contra a aids, que no Brasil são conhecidas como ONGs/aids, optam pelo uso do termo ativismo ao invés de militância. Nessa perspectiva, o ativismo seria uma nova maneira de engajamento, em contraposição à militância característica das ONGs do início dos anos 1980 no Brasil, que têm como ponto de partida problemas sociais ou causas públicas e estavam baseados no que Weber define como ética da convicção. O ativismo estaria baseado na experiência individual e íntima, no caso, o viver com HIV/aids, como condição de mobilização e de luta, resultando em um engajamento pessoal, em necessidades urgentes que demandam uma resolução no presente e centrado na ética da responsabilidade, conforme definida por Weber. Ou seja, o ativismo não teria um projeto de mudança da sociedade como um todo, mas da garantia de determinadas condições. (SILVA, 1999) 
PINELL, 2013) Assim, a burocracia estatal da saúde ligada à Política Nacional de DST/Aids é componente desses dois espaços, dentro dos quais representa o campo burocrático.

É no âmbito do Estado que se formulam as políticas de saúde, sendo indispensável pensar o Estado e sua conformação para a análise das suas respostas a problemas sociais específicos.

Analisando criticamente diversas teorias sobre o Estado, Bourdieu (1996) considerou que, para melhor compreendê-lo, seria necessário investigar o campo burocrático. Considera os burocratas não como usurpadores do universal, mas que se impõe a eles uma "referência obrigatória aos valores de neutralidade e de devotamento desinteressado ao bem público.” (BOURDIEU, 1996, p. 122) Apesar de a lei do campo burocrático ser o serviço público, o universal, os campos onde o desinteresse é a norma, não são regidos apenas pelo desinteresse. Este desinteresse é recompensado de alguma forma. O que está ausente é o interesse econômico, mas não significa que outras formas de interesse não estejam envolvidas, beneficiando-se de um lucro simbólico. Seria o interesse na economia dos bens simbólicos, que recalca o interesse econômico, que faz com que condutas adequadas sejam aprovadas e recompensadas simbolicamente. (BOURDIEU, 1996) Prestígio social que pode se transformar em vantagens econômicas. (WEBER, 1994)

O conceito de campo burocrático articula-se e desenvolve as ideias de Weber (1982) sobre a burocracia, tipo mais puro da dominação legal. Este tipo de dominação, exercida principalmente pelo servidor do Estado, apresenta como características: ordenamento por meio de leis e normas administrativas; hierarquia na organização; impessoalidade no relacionamento; especialização de funções; separação entre os meios de administração e propriedade privada; treinamento especializado e completo; cargos com competências e atribuições claras; recrutamento por meio de critérios objetivos; livre seleção para preenchimento de cargos; promoção meritocrática; disciplina sistemática e rigorosa; e controle do cargo. (WEBER, 1982, 2003) Weber (2003) destaca a consciência burocrática, pela qual o funcionário deve administrar tudo de forma apartidária, executar as ordens dos superiores como se fossem suas convicções, mesmo 
que lhe pareçam errôneas. Aí residiria a diferença entre o burocrata e o líder político: enquanto o primeiro sacrifica as suas convicções pessoais à obediência hierárquica, o segundo caracteriza-se por assumir publicamente a responsabilidade por seus atos.

A partir do desenvolvimento da teoria weberiana, Bourdieu (2012, p. 14, tradução nossa) define inicialmente o Estado como "o monopólio da violência simbólica legítima” na medida em que este é condição necessária ao exercício da própria violência física. Para Bourdieu, o Estado seria, por excelência, um lugar de concentração e de exercício do poder simbólico e resultado de um processo de convergência de diferentes tipos de capital: de força física (instrumentos de coerção), econômico, cultural (de informação), simbólico, constituindo uma espécie de meta-capital, que lhe permitiria exercer poder sobre diferentes campos e sobre diferentes tipos de capital. O Estado estaria imbricado com o campo do poder, no qual os agentes detentores de diferentes tipos de capital lutam pelo poder sobre o Estado. (BOURDIEU, 1996, 2012)

Uma vez que o Estado resulta da concentração de diferentes tipos de capital, com poder sobre eles, e que o campo burocrático é definido como o espaço de agentes e de instituições que possuem essa espécie de metapoder (BOURDIEU, 1996, 2012), o capital burocrático foi considerado como um capital delegado pelo Estado. Apesar de Bourdieu não apresentar uma definição formal de capital burocrático, ele apresenta diversas referências pontuais que permitem compreender o seu conceito. Os agentes do campo burocrático seriam os representantes do Estado, aqueles a quem o Estado delega falar em seu nome, detentores assim de um poder garantido pelo Estado. (BOURDIEU, 2012)

A obediência às injunções estatais não se trataria de uma submissão mecânica, mas de um produto da relação dos agentes com o Estado, visto que o próprio Estado impõe as estruturas segundo as quais é percebido através, principalmente, da escola. (BOURDIEU, 1996, 2012)

A religião, assim como a escola e o Estado, contribui para manutenção da ordem estabelecida - legitimação do poder dos dominantes -, assim como para a construção de um sistema de práticas e de representações que define os princípios de estruturação da percepção e do pensamento 
de mundo. (BOURDIEU, 2005) As disposições religiosas são inculcadas e podem existir de forma inconsciente, influenciando as tomadas de posição. Nesse sentido, buscou-se também analisar a formação religiosa dos agentes.

A concentração de capital jurídico pelo Estado representa uma concentração de capital simbólico que fundamenta a autoridade específica do detentor do poder estatal, especialmente do poder de nomeação, surgindo então duas formas de acesso à nobreza: a primeira, representada pela hereditariedade e o reconhecimento público (natural); a segunda, através da nomeação Estatal, garantida pelas honrarias atribuídas pelo Estado, seja um título de nobreza, seja um título escolar. Assim, cada vez mais, o capital simbólico da nobreza deixa de ser baseado apenas no reconhecimento para encontrar uma objetivação, uma codificação, delegada e garantida pelo Estado, burocratizado, conferindo posições em virtude de capital cultural adquirido através do título escolar. (BOURDIEU, 1996, 2012)

A realização de concursos e a exigência do título seriam fatores que democratizariam a entrada nos cargos públicos, permitindo o acesso aos agentes de todas as classes, ao mesmo tempo em que poderiam favorecer por algum período a entrada das classes dominantes, devido às condições mais favoráveis para o investimento no capital escolar.

Para Bourdieu (2012), o campo burocrático é o próprio Estado, uma vez que ele é o criador e garantidor dos "fetiches" de classificação, como o título escolar, a cultura legítima, a nação, a ortografia, a noção de fronteira, entre outros. O Estado seria um "banco central de capital simbólico". (BOURDIEU, 2012, p. 196, tradução nossa)

O processo de constituição do Estado é definido por Bourdieu (1997) como um processo de “desfamiliarização", trata-se de sair da lógica familiar, doméstica, para uma outra lógica. Ou seja, o Estado opõe-se à família. Ele substitui a lealdade familiar pelas lealdades formais e condena o nepotismo. Substitui a sucessão direta e hereditária (modo de reprodução dinástico) pela reprodução de base escolar (modo de reprodução burocrático). Ocorre, então, uma tripartição do poder: entre o rei, seus irmãos e os ministros, de modo que se cria uma cadeia de controle mútuo de uns 
sobre os outros, limitando e controlando o poder de cada um. E por fim, concentra o poder de nomeação.

Para Goulart (2002, 2006), uma nova burocracia vem se estabelecendo, no âmbito da saúde, ao interior do Estado brasileiro, que denomina “executivos da saúde”. Seriam aqueles funcionários não concursados que fazem carreira ao interior desse subespaço, assumindo postos em diferentes níveis da gestão da saúde pública, tendendo mais ao perfil de funcionários políticos do que administrativos, contudo, a sua manutenção no quadro de funcionários por períodos muito longos terminaria por consagrá-los como uma espécie de quadro administrativo "atípico" que, apesar de não dispor de algumas garantias trabalhistas, gozam do mesmo prestígio e têm os mesmos ganhos secundários que os funcionários de carreira. Outrossim, acrescenta-se a esse grupo o "empreendedorismo militante", característica através da qual pessoas que ocupam posições na instituição/organização seriam capazes de promover inovações devido ao seu envolvimento emocional com o objeto, com a causa em questão, o que terminaria por congregar dedicação, criatividade e iniciativa à sua atuação. (GOULART, 2002) O conceito de empreendedorismo numa perspectiva mais sociológica, segundo Mendonça, Alves e Campos (2010), é visto como um comportamento de desvio da norma, que provavelmente não é adotado por agentes em posições dominantes, geralmente comprometidos com a reprodução e manutenção da sua posição, a não ser que essas inovações contribuam para o fortalecimento do status quo. Os agentes periféricos, ou seja, essa nova burocracia ainda não estabelecida, seriam aqueles com maior predisposição a desafiar e criar novas práticas.

O poder simbólico, conforme definido por Bourdieu (2001, p. 7-8), é um “[...] poder invisível o qual só pode ser exercido com a cumplicidade daqueles que não querem saber que lhe estão sujeitos ou mesmo que o exercem", um poder conferido por um determinado grupo a partir do reconhecimento em relação a um capital, qualquer que seja a sua espécie, transmutado em capital de reconhecimento.

Desta forma, o capital burocrático foi objetivado através dos cargos ocupados, visto que quanto mais altos os postos ocupados, maior o 
poder de delegação e maior volume de recursos sob a gestão do agente. Correspondendo também ao poder de nomeação, de controle da informação e de normalização, bem como a definição e imposição de categorias estatais legítimas.

\section{Análise da gênese ${ }^{10}$ de políticas de saúde}

A partir da definição de política de saúde proposta por Paim (2002, p. 274), como:

[...] a ação ou omissão do Estado enquanto resposta social diante dos problemas de saúde (danos e riscos) e seus determinantes bem como a intervenção sobre a produção, distribuição e regulação de bens serviços e ambientes que afetam a saúde dos indivíduos e da coletividade.

Analisar a gênese de uma política de saúde, é buscar compreender o contexto político, cultural e social que determinou a necessidade de intervenção do Estado para a implementação de medidas específicas de controle de um determinado problema de saúde, ou seja, quais foram as condições que possibilitaram o reconhecimento de um determinado agravo à saúde como um problema social que exigia uma resposta governamental específica.

A seleção das categorias analíticas foi baseada na proposta de Pinell (2010) a partir do estudo da gênese de quatro políticas de saúde na França - política em favor da infância anormal, política de luta contra a toxicomania, política de luta contra o câncer e política de luta contra a aids. Os estudos de Pinell tinham a política como pano de fundo de um problema objeto de estudo sociológico, de modo que o autor realizou um esforço inverso ao da maioria dos pesquisadores de ciências políticas, analisando a política a partir do referencial teórico sociológico bourdieusiano, mas sem uma teoria prévia a ter sua pertinência verificada pela análise de caso. A posteriori,

10 O termo gênese é compreendido como origem, como conjunto de fatos ou elementos que concorrem para a formação de alguma coisa e o termo emergência é usado como seu sinônimo. 
Pinell (2010) elaborou proposições acerca dos processos comuns à emergência das políticas por ele estudadas na sua gênese e evolução.

Para a emergência de uma política pública de saúde, identificou:

1. O reconhecimento pelo poder público da necessidade de medidas específicas para o enfrentamento de um determinado problema que não tem solução satisfatória no âmbito das instituições e/ou leis existentes;

2. A responsabilização do Estado a partir da identificação de um problema já existente e da inadequação das políticas de organização e/ ou das práticas institucionais existentes;

3. A necessidade de alianças entre os diferentes grupos sociais interessados no reconhecimento de determinado problema, construindo uma definição comum do problema, apesar dos diferentes pontos de vista sobre o que é o problema ou sobre as medidas a serem tomadas;

4. A negociação para a definição de uma visão comum do problema pode levar a conflitos, a uma luta simbólica pela definição do problema e suas consequências, haja vista a concorrência aparentemente irredutível entre os grupos com interesse em construir o problema social;

5. A definição do problema constrói-se pela dinâmica de um jogo social, como produto da interpenetração das estratégias dos diferentes grupos de agentes interessados em construírem o problema como um problema social. Nesse contexto, a definição será tanto mais precisa - e restrita - quanto mais forte a concorrência entre os grupos de agentes e tanto mais imprecisa quanto os grupos interessados não são concorrentes;

6. Quando os grupos chegam a superar seus eventuais conflitos de interesse, a lógica para a elaboração de um projeto comum não é o acordo sobre uma definição precisa do problema e de suas soluções, mas de produzi-las de forma suficientemente ambíguas para não evidenciar eventuais contradições; 
7. A definição do problema e das soluções construídas antes do reconhecimento do problema pelo Estado leva a remodelações quando tem início a formulação da política específica pelos poderes públicos. A definição e a implantação de uma nova política levam a necessidade de ajustamento das políticas, instituições e estruturas já existentes. Isso se deve ao fato de que:

a. A expansão ou a criação de um novo espaço social com suas questões simbólicas, institucionais, profissionais e materiais em jogo tende a modificar os equilíbrios pré-existentes no mundo social;

b. A pressão sobre os poderes públicos de apresentar a nova política como uma expressão do interesse coletivo.

Com relação à evolução das políticas, a implantação e a evolução de uma política de saúde são produtos da dinâmica de um jogo social complexo que deve considerar:

1. As evoluções tanto de ordem médica - epidemiologia e conhecimento médico sobre a doença, técnicas, tratamentos -, como de ordem social - alterações na mobilização contra a doença;

2. Os efeitos concretos da implantação da política - novas instituições, desenvolvimento de grupos profissionais, emergência de novas estruturas associativas - e os obstáculos encontrados;

3. As mudanças de governo, sendo possível a manutenção ou a mudança da maioria política;

4. As mudanças independentes da política que afetam as instituições do campo médico - reformas hospitalares, estudos médicos - ou de outros campos implicados naquela política - educação, justiça etc. - e mais globalmente toda a sociedade - guerras ou mudanças de costumes e nas formas de controle social. (PINELL, 2010) 



\section{A gênese da política nacional de aids no Brasil (1981-1989)}

A construção de um problema, seja ele um problema de saúde ou não, como um problema social, é um processo cuja evolução é determinada pelas alianças entre os diferentes grupos interessados, de modo a transformar interesses particulares em interesses coletivos. A construção da aids como um problema social, no Brasil, teve a participação de agentes de diversos campos e subespaços, uma correlação de forças que contribuiu para o surgimento de um espaço específico de organização da luta contra a aids (espaço aids), envolvendo agentes oriundos, principalmente - não exclusivamente-do espaço militante, do campo burocrático, do campo médico, do campo científico, do campo político e mesmo do campo religioso.

O Quadro 1 apresenta uma síntese dos principais fatos históricos relacionados ao espaço aids e à gênese e evolução da política nacional de controle da aids apresentados a seguir, buscando articulá-los ao contexto político-administrativo - presidente, ministro da saúde, dirigente da política -, bem como aos subespaços específicos - campos médico, científico e burocrático, espaço militante e imprensa - e evidencia a complexidade das relações estabelecidas ao interior do espaço aids no Brasil.

A abordagem desses diferentes subespaços tornou a análise bastante complexa, de modo que a apresentação dos fatos históricos concorrentes para a conformação do espaço aids e as lutas e disputas travadas no seu interior tentou seguir a ordem cronológica, mas também a sua relação com os subespaços analisados e a evolução da política de saúde estudada.

Uma vez que a mobilização em torno da doença e a capacidade de organização de uma resposta à epidemia estão relacionados à evolução do saber médico e das estratégias de intervenção possíveis (PINELL et al., 2002), para fins de análise, foram considerados quatro momentos da 
QUADRO 1-Síntese da conjuntura política e principais fatos históricos relacionados aos campos científico, burocrático, ao espaço militante e à imprensa com relação à implantação da política nacional de controle do HIV/aids no Brasil, 1981-2001

\begin{tabular}{|c|c|c|c|}
\hline \multicolumn{4}{|l|}{ Campo médico e científico } \\
\hline & $\begin{array}{l}\text { Diagnóstico dos primeiros } \\
\text { casos no Brasil }\end{array}$ & $\begin{array}{l}\text { Diagnóstico clínico, ainda não } \\
\text { havia teste sorológico } \\
\text { Laboratório de pesquisa em } \\
\text { Aids - Fiocruz }\end{array}$ & $\begin{array}{l}20^{\circ} \text { Congresso da Sociedade Brasileira de } \\
\text { Medicina Tropical (Salvador) - Aids não era } \\
\text { prioridade }\end{array}$ \\
\hline \multicolumn{4}{|l|}{ Campo burocrático } \\
\hline & & $\begin{array}{l}\text { Reunião MHS com João Yunes } \\
\text { Aids Informações Básicas (MS) } \\
\text { Programa Estadual de Aids } \\
\text { SES-SP }\end{array}$ & \\
\hline \multicolumn{4}{|l|}{ Espaço militante } \\
\hline $\begin{array}{l}\text { Notícias sobre a nova doença } \\
\text { vistas com descrédito pelos } \\
\text { grupos homossexuais }\end{array}$ & $\begin{array}{l}\text { Grupos homossexuais passam } \\
\text { a reforçar o discurso médico }\end{array}$ & $\begin{array}{l}\text { Reunião de militantes } \\
\text { homossexuais com Ricardo } \\
\text { Veronesi (USP) }\end{array}$ & \\
\hline \multicolumn{4}{|l|}{ Imprensa } \\
\hline $\begin{array}{l}\text { Primeiras notícias sobre } \\
\text { uma nova doença nos EUA } \\
\text { (peste gay) }\end{array}$ & & $\begin{array}{l}\text { Morte de Markito }(04 / 06) \\
\text { Primeiros casos noticiados na } \\
\text { imprensa }\end{array}$ & $\begin{array}{l}\text { Notícias ligadas aos estados, ocorrência de } \\
\text { casos, sem relação com o MS }\end{array}$ \\
\hline
\end{tabular}

\section{Waldyr Mendes Arcoverde}

Figueiredo 
Hélio e Peggy Pereira

trazem culturas de HIV

Adaptação da técnica de imunofluo-rescência p/ HIV
AZT

Isolamento do vírus no

Brasil
Implantação do

Laboratório Avançado de

Saúde Pública (Fiocruz-BA)

\begin{tabular}{|c|c|c|}
\hline Programa Estadual RJ & Maria Leide DNDS & 1a Campanha nacional \\
\hline $\begin{array}{l}\text { Portaria nº } 236(02 / 05) \\
\text { Treinamento para estados }\end{array}$ & $\begin{array}{l}\text { Lair Guerra PN Aids } \\
\text { Subtema da 8a CNS }\end{array}$ & CNCSIDA \\
\hline & \multicolumn{2}{|c|}{$\begin{array}{l}\text { Debates aids e } \\
\text { constituinte }\end{array}$} \\
\hline & $\begin{array}{l}\text { Comissão de } \\
\text { Assessoramento em aids }\end{array}$ & $\begin{array}{l}\text { Recomendações } p / \text { uso } \\
\text { do AZT }\end{array}$ \\
\hline
\end{tabular}

Lei Henfil (Lei 7649)

Divisão Nacional de Aids

Projeto Previna

Constituição Federal 1988
Aquisição de AZT por alguns estados

Redução de Danos em Santos e Salvador
Hemofílicos, talassêmicos

Fundação

GAPA-SP

Primeiro cartaz de

prevenção à aids

\section{Aids era assunto frequente} na imprensa

\section{Morte de Henfil (04/01) Morte de Lauro Corona}

Lair Guerra

\begin{tabular}{c|ccc} 
Carlos Sant'Anna & Roberto Santos & Luiz Carlos Borges da Silveira & Seigo Tsuzuki \\
Sarney &
\end{tabular}

1985 
QUADRO 1-Síntese da conjuntura política e principais fatos históricos relacionados aos campos científico, burocrático, ao espaço militante e à imprensa com relação à implantação da política nacional de controle do HIV/aids no Brasil, 1981-2001

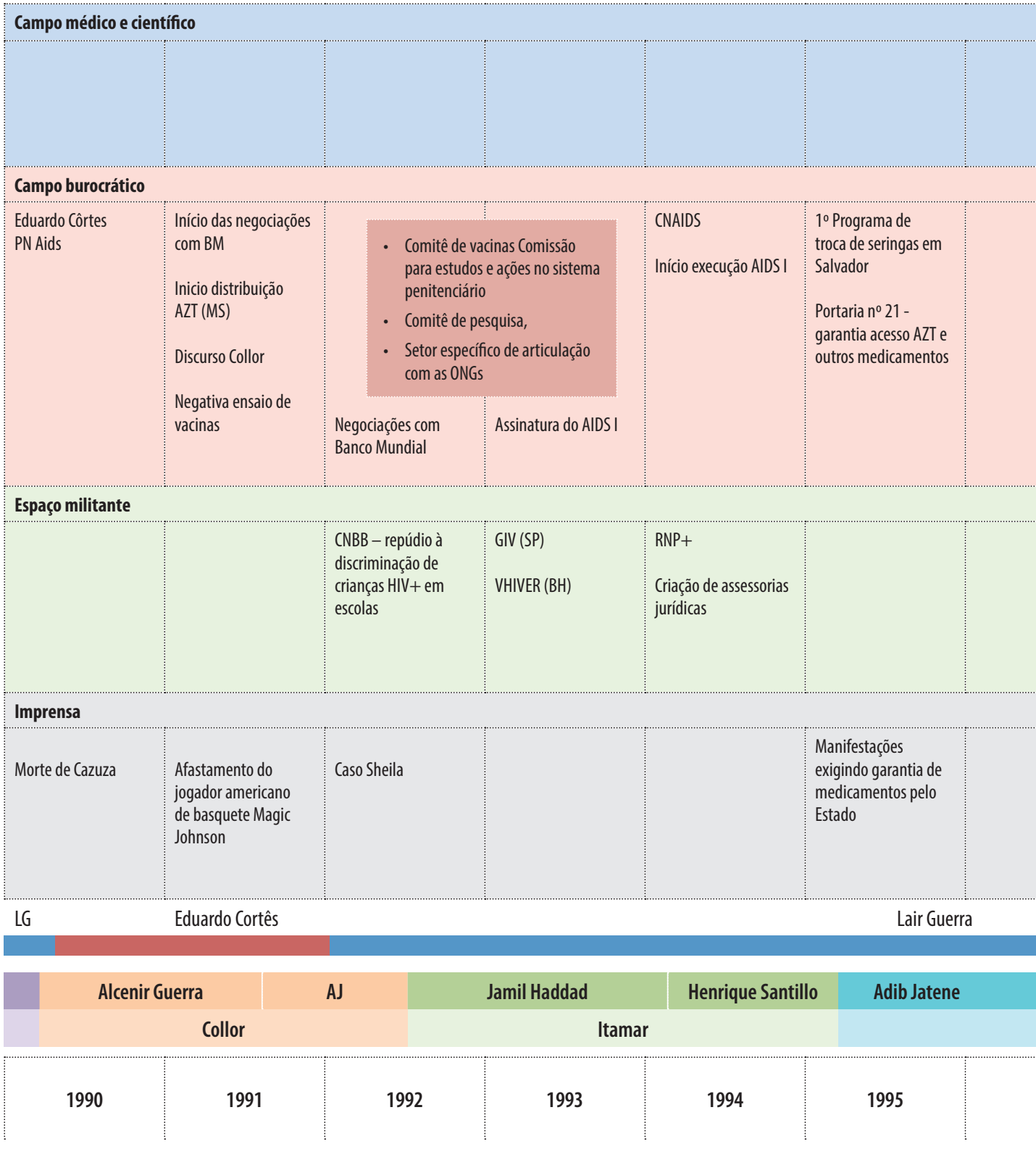

Fonte: Elaborado pela autora. 
XI Conferência

Internacional de Aids

(Vancouver)

Terapia combinada

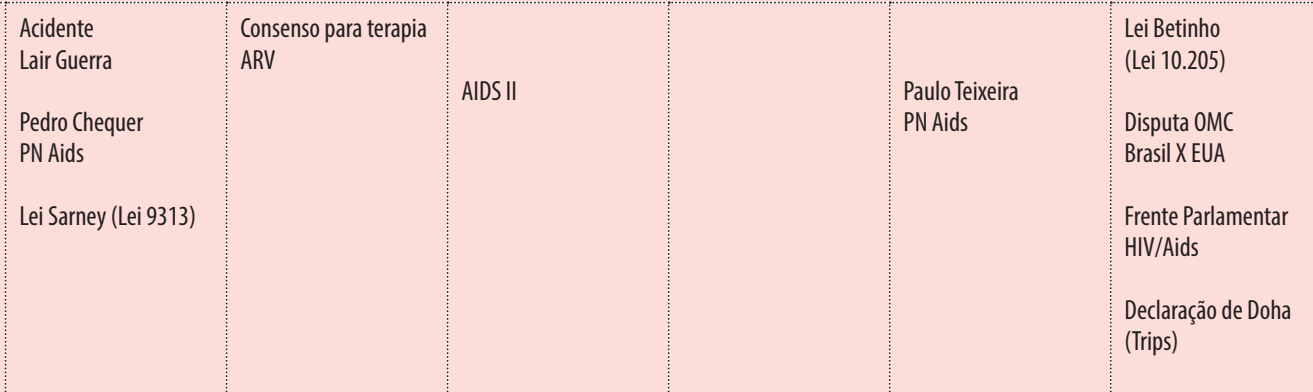

Movimento Patrocine a Vida

Ações judiciais terapia combinada

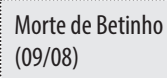

\section{José Serra}

FHC 
política nacional de controle da aids, relacionando os principais grupos atingidos, as ações prioritárias e a evolução do saber médico. (Quadro 2)

QUADRO 2 - Momentos da política nacional de controle da aids, principais grupos atingidos, ações prioritárias e sua relação com o saber médico, 1981-2001

\begin{tabular}{|c|c|c|c|c|}
\hline Período & Principais grupos atingidos* & Saber médico & Política de luta contra a aids & Ações prioritárias \\
\hline 1981-1984 & Homossexuais & $\begin{array}{l}\text { Descoberta do vírus } \\
\text { Teste sorológico }\end{array}$ & $\begin{array}{l}\text { Governo federal não possui } \\
\text { uma política específica }\end{array}$ & Iniciativas estaduais \\
\hline 1985-1989 & $\begin{array}{l}\text { Homossexuais, hemofílicos e } \\
\text { outros receptores de sangue e } \\
\text { hemoderivados }\end{array}$ & AZT & $\begin{array}{l}\text { Surgimento de uma política } \\
\text { nacional }\end{array}$ & $\begin{array}{l}\text { Ações de vigilância e } \\
\text { educação em saúde }\end{array}$ \\
\hline 1990-1996 & $\begin{array}{l}\text { Usuários de drogas injetáveis, } \\
\text { heterossexuais }\end{array}$ & $\begin{array}{l}\text { Realização de ensaios } \\
\text { para estudos de } \\
\text { vacinas no país } \\
\text { Terapia combinada } \\
\text { (controle da doença, } \\
\text { aumento da } \\
\text { sobrevida) }\end{array}$ & $\begin{array}{l}\text { Consolidação da política } \\
\text { nacional }\end{array}$ & $\begin{array}{l}\text { Distribuição de } \\
\text { medicamentos, } \\
1{ }^{\circ} \text { acordo de empréstimo, } \\
\text { financiamento ONGs }\end{array}$ \\
\hline 1997-2001 & $\begin{array}{l}\text { Feminização** } \\
\text { Envelhecimento } \\
\text { Interiorização } \\
\text { Pauperização } \\
\text { Aumento da sobrevida }\end{array}$ & $\begin{array}{l}\text { Novos medicamentos } \\
\text { (inibidores da } \\
\text { protease), redução } \\
\text { de efeitos colaterais, } \\
\text { controle da doença }\end{array}$ & $\begin{array}{l}\text { Apogeu da política nacional: } \\
\text { redução de indicadores } \\
\text { de morbimortalidade } \\
\text { (estabilização da epidemia) } \\
\text { e reconhecimento internacional }\end{array}$ & $\begin{array}{l}\text { Sustentabilidade da } \\
\text { estratégia do acesso } \\
\text { universal }\end{array}$ \\
\hline
\end{tabular}

Fonte: Elaborado pela autora.

Notas: *Fonte: Boletim Epidemiológico Aids (1987a, 1987b, 1988a, 1988b, 1990, 2001), Boletim Epidemiológico DST-Aids (1987c), Boletim Epidemiológico Aids/DST (2009, 2011), Boletim Epidemiológico HIV/aids (2014, 2015).

** Razão entre sexos no período de 1980-1990 foi de 6,5:1, e no período de 1991-2001 foi 2,4:1

Os dois primeiros momentos, que abrangem o período de 1981 a 1989, correspondem ao processo de conformação do espaço aids no Brasil, à gênese da resposta governamental no âmbito federal e ao desenvolvimento inicial da política; e são tratados nesse capítulo. Os dois momentos seguintes estão relacionados à evolução e consolidação da política nacional e serão apresentados no capítulo 4.

\section{A conformação do espaço aids no Brasil (1981-1984)}

A epidemia da aids chegou ao Brasil no início dos anos 1980, quando ainda não existia uma resposta terapêutica eficaz. O final da década de 1970 e início dos anos 1980 foi marcado pelo processo de "abertura” política e redemocratização do país, culminando com a anistia política dos exilados em 1979, na realização de eleições democráticas nos estados em 1982, 
na mobilização por eleições diretas para a presidência da república e na eleição indireta do primeiro governo federal democrático após o período de ditadura militar no início de 1985. (MACRAE, 1990) Essas condições permitiram a retomada da luta pelos direitos políticos e a constituição de um movimento social mais ativo nesse período, marcado inclusive pelo surgimento das organizações não governamentais, ${ }^{11}$ para o que contribuíram os retornados do exílio após a anistia, bem como outros que viajavam frequentemente ao exterior e aqueles relacionados a organizações como Ação Católica, ${ }^{12}$ Ação Popular $^{13}$ (AP) e Movimento de Educação de Base (MEB). (LANDIM, 2002)

A aids chegou ao país em um momento de expansão do gueto gay ${ }^{14}$ (SILVA, 1986) Desde 1976 já existiam tentativas de organização de um congresso de homossexuais no Rio de Janeiro e de formação de um grupo de discussão homossexual, mas só depois de uma visita do editor do jornal americano Gay Sunshine, Winston Leyland, em 1977 ao Brasil, que um

11 " $[. .$.$] categoria [...] usada para designar subconjuntos de organizações (como ambientalistas,$ de negros, mulheres, povos indígenas, portadores de HIV, etc.) que, embora variadas, ocupam posições análogas no campo político e social e possuem características comuns, como por exemplo: são de origem recente e ligadas em grande parte a movimentos sociais, compreendendo-se como tal também os relacionados à criação de novas identidades e à defesa de direitos específicos ou difusos; têm portanto determinados horizontes comuns no centro dos seus ideários, como a expansão de valores democráticos, de direitos civis, da cidadania; inserem-se marcadamente em redes de relações internacionalizadas, onde a questão do financiamento está de alguma forma presente." (LANDIM, 2002, p. 220)

12 Movimento controlado pela igreja católica que compreendia quatro grupos: Homens da Ação Católica e Liga Feminina de Ação Católica, para os maiores de 30 anos ou casados de qualquer idade; e Juventude Católica Brasileira e Juventude Feminina Católica, para os jovens de 14 a 30 anos. A Juventude Católica compreendia a Juventude Estudantil Católica (JEC), para os jovens secundaristas, a Juventude Universitária Católica (JUC), para os universitários, e a Juventude Operária Católica (JOC), para os jovens operários. Em 1962, militantes da JUC e da JEC criaram a Ação Popular. (KORNIS, 2001)

13 Movimento político clandestino resultado da atuação dos militantes estudantis da Juventude Estudantil Católica (JEC) e da Juventude Universitária Católica (JUC). Criado em 1962, foi um dos mais importantes movimentos de resistência ao regime militar durante a década de 1960. Em 1967 mudou sua sigla para APML (Ação Popular Marxista-Lenista) e terminou com sua incorporação ao Partido Comunista do Brasil (PC do B).

14 O termo gueto era usado entre os homossexuais para denominar locais de encontro, como bares, boates, saunas, parques, restaurantes frequentados por homossexuais de forma exclusiva ou quase exclusiva, ou para designar ruas ou locais específicos. (SILVA, 1986) 
grupo de intelectuais homossexuais fundou o jornal Lampião da Esquina, principal meio de comunicação homossexual no Brasil até 1981, quando foi editado seu último número.

Foi uma discussão sobre homossexualidade na Semana da Convergência Socialista, promovida pela Revista Versus, em 1977, que motivou João Silvério Trevisan, escritor e jornalista, e outros homossexuais ligados ao Lampião da Esquina a realizarem reuniões semanais, das quais resultou a formação do "Somos - Grupo de Afirmação Homossexual" 15 (Somos), o primeiro grupo gay do Brasil, em São Paulo. (FACCHINI, 2003; MACRAE, 1990) Foram também fundadores do Somos o antropólogo inglês Peter Fry, professor da Universidade de Campinas (Unicamp), Darcy Penteado, cenógrafo, autor teatral e um dos idealizadores do primeiro cartaz de prevenção da aids no Brasil, e o cineasta belga Jean Claude Bernadet.

A partir da criação do Somos, em 1978, houve uma proliferação de grupos de militância homossexual que lutavam pelos direitos civis dessa minoria por todo o país. (FACCHINI, 2003; MACRAE, 1990)

No Brasil, não existia uma legislação homofóbica a ser combatida como nos EUA e na França, por exemplo, mas a homossexualidade constava na lista de doenças do Instituto Nacional de Assistência Médica e Previdência Social (Inamps), o que tornava a relação com o campo médico conflituosa. (FACCHINI, 2003; MACRAE, 1990) Apesar da homossexualidade não ser crime no Brasil, a violência contra homossexuais, inclusive por parte do aparato de violência física do Estado, sempre esteve presente, sendo esta inclusive uma das principais lutas do movimento gay. (MACRAE, 1990; SILVA, 1986) Mas foram as divergências internas aos próprios grupos, resultantes do seu crescimento numérico, e a incapacidade de convivência de diferentes posições políticas entre aqueles que desejavam uma atuação mais voltada para a garantia de direitos dos homossexuais e os que propunham um engajamento político mais amplo, que levou à ruptura do Somos após o $1^{\circ}$ de maio de 1980, um “racha” no

15 O nome Somos - Grupo de Afirmação Homossexual, era uma homenagem à publicação da Frente de Liberação Homossexual Argentina, o primeiro grupo pelos direitos gays na América do Sul, que surgiu em Buenos Aires, em 1971 e foi extinta pela ditadura militar daquele país em março de 1976. (GREEN et al., 2003) 
jargão político-associativo. Dessa ruptura surgiu o Grupo Outra Coisa Ação Homossexualista e o Grupo Lésbico-feminista. (MACRAE, 1990) O Somos ainda continuou, mas, com dificuldades financeiras e dificuldades em conseguir novos membros, dissolveu-se por volta de 1983.

Uma primeira onda do movimento homossexual no Brasil teria ocorrido até 1983, coincidindo com a emergência da epidemia da aids no país, caracterizada por grupos com caráter mais comunitário e de convivência. O surgimento da epidemia da aids teria levado a transformações no movimento gay, levando a uma desmobilização em relação às propostas de liberação sexual e também devido ao envolvimento de lideranças homossexuais na luta contra a epidemia. (FACCHINI, 2003)

O Lampião da Esquina teve seu último número publicado em junho de 1981 e não chegou a mencionar a nova doença que começava a aparecer nos EUA e que a imprensa começava a noticiar no Brasil. ${ }^{16} \mathrm{O}$ fim do Lampião da Esquina ${ }^{17}$ foi outro fato que contribuiu para a desmobilização do movimento, que perdeu seu principal meio de comunicação. Essa desmobilização do movimento homossexual resultou na redução do número de grupos de 22 em 1980, para apenas 8 em 1988. Um novo crescimento do número de grupos aconteceria na década de 1990, na segunda onda do movimento gay, com grupos de caráter mais formal, aos quais a principal causa era a garantia dos direitos homossexuais e a luta contra a discriminação e violência. (FACCHINI, 2003)

As primeiras notícias sobre a nova doença, que matava rapidamente, acometia principalmente a população homossexual e se manifestava principalmente por infecções severas e pelo sarcoma de Kaposi, tinham tratamento jornalístico de um problema estrangeiro e contribuíram para a visão de uma doença de homossexuais, designando-a inicialmente de peste gay. (BARATA, 2006; SILVA, 1986) Mas, a partir daquele momento, a imprensa também assumiu um importante papel na divulgação da doença e na construção social do problema. (BARATA, 2006)

16 Acervo do jornal Lampião da esquina, 1978-1981.

17 Sobre o fim do jornal Lampião da esquina, Facchini (2003), analisa como natural que no período democrático um meio de comunicação criado para lutar contra a ditadura, com o fim da censura, também tivesse se esgotado. 
As notícias divulgadas nos meios de comunicação eram vistas com descrédito pela comunidade homossexual. A crença era que se tratava de mais uma tentativa dos médicos para atingir os homossexuais, uma forma de "usar um argumento médico para tentar fazer um retrocesso" (E8) $)^{18}$ das conquistas do movimento homossexual. (PERLONGHER, 1987) Esse era o posicionamento do grupo Moléculas Malucas ${ }^{19}$ (E8), liderado por Néstor Perlongher, professor da Unicamp e ex-militante do movimento de liberação homossexual argentino. Assim, percebia-se inicialmente uma negação do problema, exemplificada também pela primeira notícia que apareceu no boletim do Grupo Gay da Bahia (GGB), em abril de 1982, com o título “Uma doença de homossexuais??????. A matéria criticava a revista Manchete pela divulgação de uma notícia da Time Magazine considerando que se tratava de uma "grande balela" e que "toda teoria médica que parte da premissa que somos 'promíscuos' não merece confiança”. (MOTT, 2011, p. 33)

Esse posicionamento questionador em relação ao campo médico era resultado da relação histórica dos médicos com a homossexualidade, considerada como doença mental. (FATAL, 1988; MOTT, 1987) Contudo, quando o problema foi reconhecido pelo grupo, eles assumiram uma postura de reforço do discurso médico. (E2O) ${ }^{20}$ (MOTT, 1987) Em dezembro daquele ano, o discurso no Boletim do GGB já havia mudado, alertando para os sintomas da nova doença, denominada "peste rosa", referindo-se à matéria da revista Manchete e orientando aqueles que apresentassem os sintomas a procurarem o GGB. (MOTT, 2011)

Essa mudança no discurso está provavelmente relacionada aos relatos de homossexuais brasileiros que viajavam para os EUA, e que traziam notícias do pavor e das mortes (E8), bem como notícias recebidas através dos grupos estrangeiros, em especial americanos (E2O), e à ameaça representada pela epidemia ao comércio gay que começava a se desenvolver

18 Entrevista concedida por E8, antropólogo, professor universitário e ex-militante do Somos, em Salvador, em 16 de maio de 2011.

19 O termo foi adotado em referência à revolução molecular de Guattari. 
(MACRAE, 1990; PERLONGHER, 1987; SILVA, 1986), como evidenciado nas falas dos militantes:

[...] eu fui convidado para fazer uma reportagem nos Estados Unidos e passei uma semana em Nova Iorque [...] De repente, eu chego lá e todos estão apavorados. Eu fiqueisabendo de gente morrendo feito mosca. [...] Eu volteipara o Brasile os meus amigos e antigos companheiros militantes, quase ninguém acreditava. (E8)

[...] eu percebi que nem a política do avestruz, nem essa política da negação da doença ou apenas da demonização do HIV como uma doença, como uma pandemia criada em laboratório, isso não ia levar a nada. Então, eu considerei que era fundamental a participação dos movimentos homossexuais nesse esforço coletivo contra a epidemia. (E2O)

O “caso um" de aids no país começou a apresentar os sintomas de emagrecimento e sinais de fraqueza em abril de 1980, tendo ido a óbito no dia 18 de março de 1981, no Hospital São Paulo, na Vila Mariana, na cidade de São Paulo. O esclarecimento da causa da morte só aconteceu cinco anos depois, na dissertação de mestrado do médico Antônio Luiz de Arruda Mattos, que constatou se tratar de aids. (NATALI, 1990) O registro desse caso pelo Ministério da Saúde só ocorreu em 1988. (BOLETIM..., 1988b) Esse fato evidencia que o vírus já circulava no país no final da década de 1970, como enfatizado por Lair Guerra no texto Aids - A face da discriminação, no Boletim Epidemiológico Aids, ano II, n. 5, de 1988.

Apesar do importante papel assumido pela imprensa na veiculação das primeiras notícias sobre a nova doença, só em 1983 os primeiros casos brasileiros foram noticiados nos jornais. Após a leitura de uma reportagem da jornalista Letânia Menezes ${ }^{21}$ na qual era afirmado que no Brasil ainda não existiam casos da doença, a médica Valéria Petri, ${ }^{22}$ uma jovem

21 Jornalista gaúcha que começou a carreira no Jornal Zero hora de Porto Alegre, tendo trabalhado também no Globo e na revista Isto É. Foi a primeira a publicar em 1983 uma matéria sobre aids e dedicou-se a fazer matérias exclusivamente sobre esse assunto inicialmente na IstoÉ e posteriormente na Folha de S. Paulo.

22 E31, médica dermatologista, filha de imigrantes italianos, que havia terminado de concluir o doutorado e estava trabalhando com o professor Aurélio Ancona Lopes na Escola Paulista de 
dermatologista da Escola Paulista de Medicina - atual Unifesp -, contatou a jornalista da revista Isto $E$.

Eu não tinha muita convicção de que precisasse alertar o público. Não sabia a utilidade disso, mas eu não me conformava com o erro, com a informação equivocada. [...] Eu achava que precisava corrigir a matéria errada. (E31)

Os casos haviam sido identificados em setembro de 1982 e janeiro de 1983, na cidade de São Paulo. Eram dois homens, um de 32, outro de 30 anos, homossexuais, que apresentavam lesões de pele (sarcoma de Kaposi) e haviam viajado recentemente aos EUA (E31). (ABBADE; BAIÃO, 2010; FRANÇA, 2008; GUERRA, 1993; MARQUES, 2003)

A dermatologia desempenhou importante papel no diagnóstico dos primeiros casos, justamente por conta do sarcoma de Kaposi, uma lesão de pele pouco comum em jovens, que se mostrava presente na maioria dos casos. Naquele momento, ainda não havia testes sorológicos. O diagnóstico era clínico, associado ao diagnóstico histopatológico de sarcoma de Kaposi e às características do paciente - homem, homossexual, 30-32 anos, que viveu em Nova Iorque -, ainda que a lesão não fosse típica. (E31)

A divulgação dos casos causou alguns incômodos, talvez por se tratar de uma mulher jovem, dermatologista, recém-doutora, ainda uma recém -ingressa no campo científico e no campo médico; dessa forma, a veracidade do diagnóstico foi questionada por alguns médicos infectologistas.

Mas foi muito difícil lidar com isso porque além de não haver perspectiva nenhuma de tratamento, ainda era tudo muito assustador, havia ainda colegas que insistiam em que eu estava mentindo. (E31)

A Folha de São Paulo, um dos principais jornais do país, só mencionou os dois casos em junho de 1983, quase um ano após a detecção. ${ }^{23} \mathrm{Na}$ literatura médica brasileira, a Revista Paulista de Medicina apresentou os

Medicina e no seu consultório particular. Concedeu entrevista em São Paulo, em 20 de junho de 2011.

23 Ver Rocha (1983). 
primeiros relatos de casos no número de julho/agosto de 1983. Dois casos ocorridos no estado de São Paulo: um identificado em julho de 1982, em Campinas, na Disciplina de Doenças Transmissíveis da Faculdade de Ciências Médicas da Unicamp, que foi a óbito cinco dias após a internação (GONÇALES JÚNIOR et al., 1983); outro descrito como primeiro caso autóctone do país por docentes da Clínica de Doenças Infecciosas e Parasitárias da Faculdade de Medicina da Universidade de São Paulo (USP) e da disciplina de Imunologia da Escola Paulista de Medicina (EPM). (AMATO NETO et al., 1983)

A sigla referente ao nome da doença em português, Síndrome da Imunodeficiência Adquirida (Sida), não emplacou no Brasil, prevalecendo o uso da sigla em inglês, Autoimmune Deficiency Syndrome (AIDS). Desde as primeiras notícias veiculadas na mídia, a imprensa e os médicos incorporaram o termo em inglês, em uma clara influência da língua inglesa, que pode ser classificado como um estrangeirismo. Durante algum tempo, o Ministério da Saúde tentou usar o termo Sida, presente em diversos documentos, mas sempre associado ao termo aids. Em 1997, uma reportagem da revista Veja levantava o porquê do termo Sida não ser adotado no país e considerando-se mirabolante a explicação de o termo não ser usado devido às piadas que faziam com as Aparecidas cujo apelido Cida era muito comum, além da possível referência à Santa Padroeira do Brasil, Nossa Senhora da Conceição Aparecida. (SCALZO, 1997) Ainda que o uso do termo aids tenha sido preferido pela imprensa e pelos médicos desde as primeiras notícias, segundo um dos entrevistados, essa discussão acerca do uso dos termos aids ou Sida teria de fato existido, tendo inclusive ocorrido uma reunião no Ministério da Saúde para decidir que termo usar. (E11) 24 Ou seja, houve uma racionalização para justificar a submissão aos EUA, tanto no campo científico como no campo cultural.

[...] naquela época eu era quase que estagiário, e eu participei das reuniões na criação do programa. E me lembro que o Brasilé o único pais do mundo que não chama Sida. É o único pais da América Latina que não chama Sida. Que era... que em agosto de 2011. 
português seria Síndrome da Imunodeficiência Adquirida e a gente chama aids. Eu estava presente na reunião principal onde se decidiu que no Brasil não ia se chamar Sida. Por causa das Aparecidas, que são Cidas.

Entrevistador: Éverdade essa história?

É verdade. História verdadeira. Assim, pra não estigmatizar todas as Aparecidas que se chamavam Cida. É por isso que ficou aids. (E11)

Em 1983, começaram também a surgir notícias relacionadas ao uso de interferon como tratamento para a aids. ${ }^{25} \mathrm{O}$ médico Ricardo Veronesi, ${ }^{26}$ um dos responsáveis pela aplicação do interferon como tratamento para aids no Brasil, iniciativa de uma empresa farmacêutica suíça que fornecia o medicamento gratuitamente, realizou uma reunião por volta de março ou abril de 1983, buscando uma maior aproximação com o principal grupo acometido pela epidemia, evento que reuniu diversos militantes do movimento homossexual, entre eles componentes do Grupo Somos que não se encontravam desde o "racha" do grupo, alertando-os para a necessidade de uma resposta do Estado (E8). (HC INICIA..., 1983)

São Paulo tinha naquele momento em seu primeiro governo estadual eleito pelo voto popular, ainda durante o período da ditadura militar, em 1982. O governador era Franco Montoro, ${ }^{27}$ do Partido do Movimento

25 C.. INTERFERON..., 1983; CONGRESSO..., 1983.

26 Médico, Professor da Faculdade de Medicina de São Paulo, fundador da Sociedade Brasileira de Infectologia, criada justamente porque junto com o prof. Paulo Augusto Ayrosa Galvão, Veronesi considerava que havia a necessidade de uma especialidade que englobasse de forma mais abrangente as doenças infecciosas e parasitárias, haja vista que as epidemias hospitalares e a pandemia de HIV/aids não cabiam na Medicina Tropical, que tratava principalmente das questões de saúde pública, e que não estavam relacionadas apenas aos trópicos. (SBI, 2005)

27 Bacharel em Direito pela USP (1938), Montoro foi professor universitário da PUC-SP (19381940), procurador do estado de São Paulo (1940-1950), vereador do município de São Paulo pelo Partido Democrata Cristão (PDC) em 1950, deputado estadual em 1954, e deputado federal em 1958, 1962 e 1966, esta última já pelo MDB. Foi Ministro do Trabalho e Previdência Social (1961-1962) durante o governo parlamentarista. Com a instauração do bipartidarismo no Brasil, ingressou no oposicionista Movimento Democrático Brasileiro (MDB). Foi senador em 1970 e governador do estado de São Paulo em 1982. Foi sua a iniciativa de realização do primeiro comício pelas eleições diretas para presidente da república em São Paulo no ano de 1984. (MAYER; MONTEIRO; ALDÉ, 2001) 
Democrático Brasileiro (PMDB), que congregava uma frente de partidos clandestinos como Partido Comunista Brasileiro (PCB) e Partido Comunista do Brasil (PC do B), e que se opunha à ditadura. Na Secretaria de Saúde do Estado de São Paulo (SES-SP), João Yunes ${ }^{28}$ foi nomeado para o cargo de secretário. Naquele período, a SES-SP já contava com um sistema de saúde organizado e um quadro técnico qualificado, haja vista a reforma administrativa do final da década de 1960, denominada Reforma Leser, que promoveu a integração dos serviços no nível local, tendo os centros de saúde como eixo; a descentralização executiva com a criação de distritos sanitários; a elaboração de normas técnicas; a implantação de sistemas de planejamento, epidemiologia, estatística; a qualificação profissional e a criação de carreiras específicas no âmbito da Saúde Pública, com regime de dedicação exclusiva e boas condições de trabalho; bem como a criação de uma superintendência de saneamento ambiental. (RIBEIRO, 2008)

A emergência da política de controle da aids no estado de São Paulo ${ }^{29}$ ocorreu a partir da reunião de um grupo de militantes do movimento pelos direitos dos homossexuais com o Secretário da Saúde de São Paulo, João Yunes. (BARBOZA, 2006; GUERRA, 1993; MARQUES, 2003; TEIXEIRA, 1997) Essa audiência foi agendada por Darcy Penteado, motivada pela reunião com o médico Ricardo Veronesi, pela notícia dos primeiros casos de aids identificados no Brasil e diante das notícias trazidas por pessoas que viajavam aos EUA. (E8; E26; E31)

Foi de maneira bem simples, uma demanda iniciada por pessoas que tinham de uma ou outra maneira, com uma ou outra intensidade, história de participação no movimento pelos direitos dos homossexuais. [...] e cobraram da secretaria como, digamos, um representante da comunidade homossexual, providências,

Médico graduado pela USP em 1963, concluiu o Mestrado na Escola de Saúde Pública da Universidade de Michigan, Ann Arbor, Estados Unidos, em 1967. Especializou-se em Pediatria em 1970. Em 1971 concluiu o Doutorado na Faculdade de Medicina da USP. Além de Secretário da Saúde de São Paulo (1983-1987), João Yunes assumiu cargos no Ministério da Saúde do Brasil (1975-1979; 1998-2000), na OPAS (1987-1998) e foi diretor da Escola de Saúde Pública da USP. (2001-2002) consultar: Guerra (1993); Silva (1986); Barboza (2006) e França (2008). 
orientações, informações a respeito da epidemia diante do pânico que se criava no meio homossexual. (E26) 30

Tratava-se de umgrupo de ex-integrantes doSomos e dojornal Lampião da Esquina, composto por Darcy Penteado, Edward MacRae, Jean Claude Bernadet e João Silvério Trevisan, acompanhados da médica Valéria Petri. O grupo solicitava um pronunciamento da SES-SP sobre a aids e providências no atendimento a futuros casos. (E8; E26; E31) Após esse encontro, começou o movimento na SES-SP para a criação do Programa de Aids. Isso ocorreu através de um grupo de trabalho composto por técnicos - médicos sanitaristas, infectologistas, especialistas na área de laboratório e na área social - de diversos setores da secretaria, coordenado pela divisão de Hansenologia e Dermatologia Sanitária, que estava estruturando um serviço de doenças sexualmente transmissíveis (TEIXEIRA, 1997) e que tinha à sua frente o dermatologista sanitário Paulo Roberto Teixeira, coincidentemente, ex-integrante do Somos. (E26)

Assim, os principais fatos que contribuíram para a concretização do Programa de Aids na SES-SP, conforme já destacado em outros estudos, ${ }^{31}$ foram a existência de casos já diagnosticados em São Paulo; a demanda de um grupo de militantes homossexuais reforçado pelo apoio da médica da Escola Paulista de Medicina, Valéria Petri; e as condições políticas - um governo democrático, no qual militantes da reforma sanitária assumiram posições estratégicas. Acrescente-se a estes o pavor suscitado pela epidemia e o grupo social atingido, não apenas um grupo organizado, mas de classe social elevada, composta por intelectuais de diferentes áreas e com importante capital social; o fato de o Estado já dispor de um sistema de saúde organizado e um quadro técnico qualificado desde a década de 1960, inclusive com a carreira de sanitarista, resultado da Reforma Leser; e a existência de um diretor sanitarista e ex-integrante do movimento homossexual, ou seja, uma pessoa não apenas acostumada a trabalhar com pessoas estigmatizadas, mas também integrante de um grupo minoritário,

Entrevista concedida por E26, médico e gestor, em São Paulo, em 3 de maio de 2011. 
o que lhe conferia disposição para trabalhar com populações marginalizadas, fossem os portadores de hanseníase ou os "transgressores da moral e dos bons costumes" como eram vistos os portadores de HIV/aids, homossexuais, usuários de drogas injetáveis e profissionais do sexo, à exceção dos hemofílicos, vistos como vítimas da irresponsabilidade alheia.

[...] quando havia uma insinuação de que eu estava promovendo isso porque eu era homossexual, eu nunca me envolvi nessa discussão, nunca gastei energia nessa discussão. E quando eventualmente eu fazia, me lembrava e lembrava as pessoas do envolvimento eproblemas que tinha por trabalhar com hanseníase [...] Nós estamos falando de um grupo de cidadãos historicamente estigmatizados, discriminados e o primeiro responsável por defender e apoiar essa comunidade éo Estado. (E26)

A partir da criação do Programa Estadual de São Paulo, começou a se estabelecer um espaço de articulação entre agentes de diferentes campos e espaços - campo médico, campo científico, campo burocrático, campo político e espaço militante - preocupados em organizar a resposta à epidemia da aids, o espaço aids, conforme definido por Pinell e colaboradores (2002).

O grupo Outra Coisa/Ação Homossexualista, uma das dissidências do Somos, tornou-se um importante parceiro do Programa de Aids da SES-SP, sendo um intermediário na comunicação com a comunidade gay. O grupo era responsável por distribuir folhetos explicativos sobre os sintomas da aids e como agir em bares, restaurantes, saunas, ruas e praças públicas frequentadas pela comunidade homossexual. A elaboração do primeiro material foi supervisionada pelos médicos Ricardo Veronesi, da USP, e Valéria Petri, da Escola Paulista de Medicina. O Instituto Adolfo Lutz ficou responsável pela realização de testes gratuitos, e a seção de Dermatologia da Escola Paulista de Medicina e o serviço de moléstias infecciosas do Hospital das Clínicas (USP) ficaram definidos como locais para atendimento. (ROCHA, 1983)

Ainda que nesse momento o Ministério da Saúde não estivesse atento à epidemia, também houve envolvimento de instituições federais de ensino e/ou pesquisa, por iniciativa dos próprios docentes/pesquisadores. Assim, também em 1983, foi criado o Laboratório de Pesquisa em Aids 
na Fundação Osvaldo Cruz (Fiocruz), no Rio de Janeiro, iniciativa de Bernardo Galvão de Castro Filho, médico, coordenador do laboratório, com mestrado em Patologia Humana (UFBA) e Doutorado em Imunologia, em Genebra, na Suíça, e de Claudio Ribeiro, médico com doutorado em imuno-hematologia na França. O laboratório surgiu do Laboratório de Imunologia Parasitária da Fiocruz no Programa de Pesquisas em Doenças Tropicais, que mais tarde se transformou no Departamento de Imunologia do Instituto Oswaldo Cruz..$^{32} \mathrm{~A}$ partir do contato com um paciente de aids, Galvão e Claudio Ribeiro viram a necessidade de estudar a doença e conseguiram aprovar um projeto junto ao CNPq para estudar casos de aids no Brasil, com o objetivo de verificar se as alterações imunobiológicas eram semelhantes às encontradas em pacientes de outros países. (MOURA, 2005) Esta pode ter sido uma oportunidade para os dois recém-doutores criarem sua própria linha de pesquisa, diferente daquela da imunopatologia, com ênfase em chagas e esquistossomose.

Além disso, a médica Valéria Petri, na Escola Paulista de Medicina, assim como ocorreu em outras escolas federais e estaduais, iniciava assistência aos primeiros pacientes identificados, mesmo que sem muitas possibilidades de tratamento. (E31)

Desta forma, o espaço aids, desde seus primórdios, envolveu importantes instituições universitárias, como a Universidade de São Paulo e a Fiocruz, às quais estavam vinculados alguns agentes.

Os principais agentes envolvidos no início da luta contra a epidemia no país ou pertenciam ao principal "grupo de risco" (homens homossexuais) ou eram profissionais da área da saúde, em especial médicos - dermatologistas, infectologistas, patologistas ou imunologistas- que

O projeto foi desenvolvido a partir de 1978, quando Bernardo Galvão havia acabado de retornar de Genebra, onde foi fazer o Doutorado em Imunologia (1974-1977), orientado por Paul Henri Lambert (que entre 1975 e 1987 liderava o Immunology Research and Training Programme da OMS e o Laboratório de Pesquisas da OMS na Universidade de Genebra e Lausanne, onde Galvão trabalhou durante os anos que ficou em Genebra). O projeto inicial pedia, por sugestão de Paul Henri, colaboração de Genebra para a organização do Laboratório de Imunologia Parasitária da Fiocruz. Em 1981, o projeto final foi aprovado. Esse laboratório, segundo Galvão, tornou-se "foco de atração para recém-doutores que estavam retornando ao país" (Entrevista concedida por E4, médico patologista e pesquisador da Fiocruz, em Salvador, em 12 de julho de 2011). 
tiveram contato com a epidemia no exercício profissional e eram, praticamente todos, servidores públicos, estaduais e/ou federais. Verificou-se que os servidores federais, no seu discurso destacavam que se tratava, de alguma forma, de uma iniciativa individual, mas representando o Estado, por se considerarem agentes do Estado.

Na reunião como Yunes foi imediata a coisa. Ele disse: 'vocêna Escola Paulista faz o que você puder e nós vamos fazer na secretaria o que a gente puder.' Quer dizer que no nivel federal eu estava me mexendo. (E31)

[Entrevistador:] Então eram ações individuais, sem interferência (ou apoio) do governo?

Galvão [Bernardo Galvão Castro Filho]: Algumas passaram pelo Estado porque os pesquisadores representavam o Estado. (BROTAS, 2007)

A emergência do Programa Estadual de Aids da SES-SP conformou, assim, um espaço específico de organização da luta contra a epidemia da aids, sendo também um espaço de pesquisa e intervenção, envolvendo agentes do movimento homossexual (espaço militante), do campo médico, que também eram docentes e pesquisadores (campo científico) ou atuavam na secretaria de saúde do estado (campo burocrático).

\section{Quem se interessava pela aids e por quê?}

Entre os 33 entrevistados, 20 inseriram-se no espaço aids até 1986. Oito no subespaço burocrático, seis no subespaço militante e seis no subespaço científico. O interesse desses agentes pela aids, ou seja, aquilo que os motivou a entrar nesse espaço de lutas e intervenção médico-sanitária de resposta à epidemia, no período entre 1983 e 1986 esteve relacionado ou ao pertencimento a grupos de risco ou ao contato prévio com a doença, seja por motivos pessoais; doentes, parentes e amigos, ou amigos de profissionais ou militantes que também se sensibilizavam com a epidemia, seja por questões profissionais, associadas ou não a razões de ordem pessoal. (Quadro 3) 
QUADRO 3 - Perfil dos entrevistados, segundo graduação, ano de entrada no espaço aids, subespaço de inserção, volume de capital científico, burocrático, político e militante, relação com a aids e presença no espaço aids na emergência da política nacional de controle da epidemia (1985)

\begin{tabular}{|c|c|c|c|c|c|c|c|c|c|c|}
\hline \multirow[b]{2}{*}{$E$} & \multirow[b]{2}{*}{$\begin{array}{l}\text { Graduação } \\
\text { (instituição, ano) }\end{array}$} & \multirow{2}{*}{ 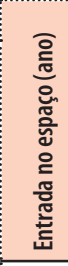 } & \multirow[b]{2}{*}{ 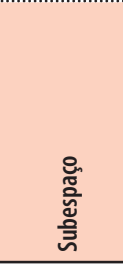 } & \multicolumn{5}{|c|}{ Volume de capital (1983-1986) } & \multirow[b]{2}{*}{$\begin{array}{l}\text { Relação com } \\
\text { a aids }\end{array}$} & \multirow{2}{*}{ 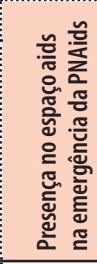 } \\
\hline & & & & $\frac{\text { 旁 }}{3}$ & : & 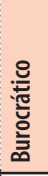 & $\frac{.3}{\frac{3}{2}}$ & 壱 & & \\
\hline 1 & Ciências Sociais (PUC-SP, 1992) & 1983 & Burocrático & $E M$ & - & - & - & - & Profissional & $x$ \\
\hline 2 & Medicina (UFBA, 1985) & 1993 & - & & & & & & Profissional & \\
\hline 3 & Direito (PUC-SP, S/I) & 1983 & Militante & $S$ & - & - & $P$ & $P$ & $\begin{array}{l}\text { Profissional/ } \\
\text { Pessoal }\end{array}$ & $x$ \\
\hline 4 & Medicina (UFBA, 1969) & 1983 & Científico & $P G$ & $A A$ & $P$ & $p$ & - & Profissional & $x$ \\
\hline 5 & Ciências Sociais (UFRJ, 1988) & 1989 & Militante & & & & & & Profissional & \\
\hline 6 & Filosofia (UNESP, S/I) & 1994 & Militante & & & & & & Pessoal & \\
\hline 7 & Medicina (UFRJ, 197?) & 1983 & Científico & $S$ & - & - & - & - & Profissional & \\
\hline 8 & $\begin{array}{l}\text { Psicologia Social (Univ. Sussex } \\
1968 \text { ) }\end{array}$ & 1983 & Militante & $P G$ & $M$ & - & - & $P$ & Política & $x$ \\
\hline 9 & Medicina (UFBA, 1965) & 1985 & Científico & $P G$ & $A$ & - & - & - & Pesquisa & $x$ \\
\hline 10 & Medicina (UFBA, 1968) & 1985 & Burocrático & $P G$ & $P$ & $A A$ & $p$ & - & Profissional & $x$ \\
\hline 11 & Medicina (UFPI, 1983) & 1986 & Burocrático & $S$ & - & $A$ & - & - & $\begin{array}{l}\text { Profissional/ } \\
\text { Pessoal }\end{array}$ & $x$ \\
\hline 12 & $\begin{array}{l}\text { Administração (Centro } \\
\text { Universitário Metodista - SP, } \\
\text { após 2001) }\end{array}$ & 1986 & Militante & & & & & & Pessoal & \\
\hline 13 & $\begin{array}{l}\text { Hotelaria (Faculdade Hebraico } \\
\text { Brasileira Renascença, 1994) }\end{array}$ & 1994 & Militante & & & & & & Pessoal & \\
\hline 14 & $\begin{array}{l}\text { Administração (UCSAL, após } \\
\text { 2001) }\end{array}$ & 1987 & Militante & & & & & & & \\
\hline 15 & Turismo $(S / I)$ & 1986 & Burocrático & $S$ & - & $P$ & - & - & Profissional & \\
\hline 16 & Medicina (EBMSP, 1981) & 1990 & Científico & & & & & & Profissional & \\
\hline 17 & $\begin{array}{l}\text { Sociologia (Escola de Sociologia } \\
\text { Política de São Paulo, S/I) }\end{array}$ & 1992 & Burocrático & & & & & & Profissional & \\
\hline 18 & $\begin{array}{l}\text { Matemática (Universidad de } \\
\text { Buenos Aires, 1972) }\end{array}$ & 1986 & Militante & $P G$ & $M$ & - & $P$ & $A$ & Pessoal & \\
\hline 19 & Medicina (USP, 1961) & 1983 & Científico & $P G$ & $A$ & $A$ & $P$ & - & Profissional & $x$ \\
\hline 20 & Ciências Sociais (USP, 1968) & 1983 & Militante & $P G$ & $M$ & - & $P$ & $A$ & Política & $x$ \\
\hline 21 & Economia (UnB, após 2001) & 1986 & Burocrático & $E F$ & - & - & - & - & Profissional & \\
\hline 22 & Psicologia (UFBA, 1991) & 1987 & Militante & & & & & & Pessoal & \\
\hline 23 & Medicina (UFBA, 1989) & 1990 & Burocrático & & & & & & & \\
\hline 24 & Medicina (EMESCAM, 1975)* & 1985 & Burocrático & $S$ & - & $A$ & - & $P$ & Profissional & $x$ \\
\hline 25 & Ciências Sociais (Unesp, 1987) & 1988 & Científico & & & & & & & \\
\hline 26 & Medicina (Unesp, 1973) & 1983 & Burocrático & $S$ & - & $A$ & - & $P$ & Profissional & $x$ \\
\hline 27 & Medicina (UFRJ, 1986) & 1986 & Burocrático & $S$ & - & $A$ & - & - & Profissional & \\
\hline
\end{tabular}




\begin{tabular}{|c|c|c|c|c|c|c|c|c|c|c|}
\hline \multirow{2}{*}{$\mathrm{E}$} & \multirow{2}{*}{$\begin{array}{l}\text { Graduação } \\
\text { (instituição, ano) }\end{array}$} & \multirow{2}{*}{ 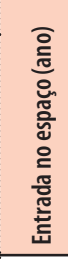 } & \multirow[b]{2}{*}{ 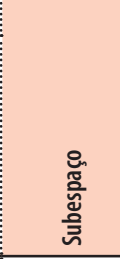 } & \multicolumn{5}{|c|}{ Volume de capital (1983-1986) } & \multirow{2}{*}{$\begin{array}{l}\text { Relação com } \\
\text { a aids }\end{array}$} & \multirow{2}{*}{ 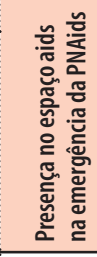 } \\
\hline & & & & $\frac{\overline{0}}{3}$ & 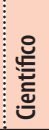 & 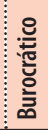 & $\frac{\stackrel{2}{*}}{\frac{3}{2}}$ & 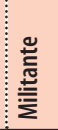 & & \\
\hline 28 & $\begin{array}{l}\text { Tecnólogo em processamento } \\
\text { de dados (S/I) }\end{array}$ & 1993 & Burocrático & & & & & & Profissional & \\
\hline 29 & Psicologia (PUC, 1978) & 1986 & Militante & $P G$ & $P$ & - & $p$ & A & Profissional & \\
\hline 30 & Medicina (UERJ, 1985) & 1986 & Científico & $S$ & - & - & - & - & Profissional & \\
\hline 31 & Medicina (Unifesp, 1973) & 1983 & Científico & $\begin{array}{l}\text { PG } \\
\text { P }\end{array}$ & $M$ & $\vdots-$ & - & $\vdots-$ & Profissional & $x$ \\
\hline 32 & Psicologia (USP, 1977) & 1984 & Científico & & & & & & Profissional & $x$ \\
\hline 33 & Psicologia (UERJ, 1985) & 1985 & Militante & $P G$ & $P$ & - & $p$ & A & Política & $x$ \\
\hline
\end{tabular}

Fonte: Elaborado pela autora.

Notas: E: entrevistado; PUC-SP: Pontifícia Universidade Católica de São Paulo; UFBA: Universidade Federal da Bahia; S/I: sem informação; UFRJ: Universidade Federal do Rio de Janeiro; Unesp: Universidade Estadual Paulista "Júlio de Mesquita Filho"; US: University of Sussex; UFPI: Universidade Federal do Piauí; UCSal: Universidade Católica de Salvador; EBMSP: Escola Bahiana de Medicina e Saúde Pública; UBA: Universidad de Buenos Aires; USP: Universidade de São Paulo; UnB: Universidade de Brasília; EMESCAM: Escola Superior de Ciências da Santa Casa de Misericórdia de Vitória; PUC-RJ: Pontifícia Universidade Católica do Rio de Janeiro; UERJ: Universidade do Estado do Rio de Janeiro; Unifesp: Universidade Federal de São Paulo; EM: ensino médio; S: superior completo; PG: pós-graduação; EF: ensino fundamental, AA: volume de capital científico muito alto; M: volume de capital científico médio; A: volume de capital científico alto; B: volume de capital científico baixo; PNAids: Política Nacional de Aids

*Contato por correspondência eletrônica.

Aqueles que entraram no espaço, exclusivamente a partir de um motivo pessoal, eram todos participantes de movimentos homossexuais ou já tinham diagnóstico sorológico para HIV. A sua inserção no espaço aids se deu a partir do subespaço militante. Alguns continuaram no espaço aids, como E20 e E18, sendo que o primeiro mantendo-se no movimento gay e o segundo em associações específicas de luta contra a aids. Outros migraram para os demais subespaços, como E8, que transitou pelo espaço burocrático e consolidou-se no espaço científico, desvinculando-se em meados da década de 1990 do espaço aids. Lutar contra a aids era lutar em defesa da causa homossexual, não apenas como uma questão de sobrevivência, mas também relacionada à concepção da doença, da sexualidade, de suas práticas.

Os agentes que começaram a sua relação com a aids, devido a questões profissionais, inseriram-se principalmente no campo científico ou 
burocrático, assumindo posições em programas estaduais e no Programa Nacional (E26, E27, E1). Duas agentes incorporaram-se ao espaço militante: E3, no Grupo de Apoio e Prevenção à Aids (Gapa), e E29, na Associação Brasileira Interdisciplinar de Aids (Abia). É importante notar que são duas situações bastante específicas. E3 participou de uma das reuniões iniciais de formação do Gapa devido a um encontro profissional com uma cliente que era assistente social do Hospital Emílio Ribas. Mas no seu relato também citou a participação de pelo menos um amigo naquela reunião.

[...] eu não tinha nenhuma vinculação, até porque, não suportava e mesmo assim hoje eu tenho um pavor de doença, [...] Eu tinha uma cliente que era assistente social, $[. .$.$] e ela [. .$.$] falou que precisava ter uma conversa comigo enquanto ad-$ vogada. Eu falei: 'Tudo bem, pode vir aqui hoje.' [...] Aí ela: 'Não, vai ser muito tarde, daria para você me encontrar lá??' [...] Eu fiquei pensando, para eu sair do escritório, ir para minha casa... Eu decidi ir direto [...], tinha uma reunião. Aí eu comecei a participar. [...] estava todo mundo sentado em círculo e eu sentei na cadeira depois, no outro círculo. Porque eu não fazia parte daquela reunião [...] sobre aids. Uma das primeiras reuniões... O que vai fazer, o que não vai fazer... E o pessoal todo desesperado. E eu, [...] verificando assim pela parte mais prática, sem a emoção da situação, eu via a solução. Eu ficava pensando: por que eles não fazem tal coisa? [...] E eu peguei a pessoa falando e eu já mentalizando como éque seria. Quando terminou a reunião, começou a passar uma relação em uma lista para saber quem estava presente na reunião e quem podia ajudar, qual horário, aquela coisa toda. Aí veio passando e quando chegou na mão de um amigo nosso que era voluntário e estava naquele momento ali, [...] passou para mim. Aí eu falei: 'Desculpa, mas eu estou fora da rodinha.' Ele falou: 'E você não pode ajudar porque esta fora da rodinha?' [...] eu olhei e vi que o único horário que eu tinha livre era sábado 3 horas da tarde, porque o resto da semana toda era ocupada. [...] depois eu verifiquei que a maioria também era no sábado. E coincidia o horário. Então nós começamos a fazer as reuniões a partir daquele ano, sábado às 3 horas da tarde. $\left(\mathrm{E}_{3}\right)^{33}$ Paulo, em 20 de junho de 2011. 
E3 associou a prática profissional à militância. Ela conseguiu construir uma trajetória militante relacionada à sua trajetória profissional, criando a primeira assistência jurídica para pessoas com HIV/aids. Em 2012 continuava atuando como advogada e militante.

E29 foi convidada por Betinho para elaborar o projeto da Abia na expectativa de, conseguindo um financiamento, tornar-se funcionária da instituição. Integrou-se ao quadro de funcionários da associação, assumindo uma posição intermediária na diretoria da Abia, de modo que fez uma trajetória profissional ao interior do subespaço militante. Saiu da Abia em 1991 e também da militância na área de aids.

[...] Começa com a proposta do Betinho para que eu viesse a ajudar a colocar em pé uma entidade, a Abia, que na época não tinha o nome de Abia. A ideia era fundar uma fundação que era um branch, uma sucursal da [International] Interdisciplinary Aids Foundation, IIAF, a ideia que ele tinha era que fosse uma fundação. Como a legislação de fundação no Brasil era muito problemática, resolvemos criar uma associação. A Abia não existia ainda, então o Betinho me convidou para isso. (E29) ${ }^{34}$

É interessante notar que os agentes com menor volume de capital cultural, ou escolar, e científico foram aqueles relacionados ao campo burocrático. Praticamente todos os agentes que possuíam algum volume de capital científico se inseriram no campo científico ou no espaço associativo. Dos seis agentes do espaço científico aqui analisados, apenas um não possuía pós-graduação stricto senso, todos os demais possuindo mestrado e/ou doutorado, que correspondiam respectivamente ao baixo e médio volume de capital científico. Contudo, os que apresentaram maior volume de capital científico foram aqueles que se mantiveram no subespaço científico, também ao interior do espaço aids, como E4, E9 e E19, sendo que este último teve uma participação inicial mais tangencial, enquanto diretor no Instituto de Saúde da SES-SP, depois dando seguimento a sua trajetória acadêmica voltado para o estudo de vacinas. 
Os agentes do subespaço burocrático foram os únicos a apresentar o capital especifico desse campo, à exceção, naquele momento, dos então estagiários do Programa Estadual de Aids de São Paulo, E1, e do Programa Nacional de Aids, E21, que fizeram carreira naquele subespaço até o final do período estudado, ou seja, os agentes do campo burocrático que foram trabalhar na área de aids eram técnicos de carreira, que já vinham assumindo posições na burocracia estatal ou recém-ingressos nesse campo.

Outra questão importante foi que nos espaços mais institucionalizados, como os campos burocrático e científico, havia um predomínio do campo médico. No campo burocrático, os médicos assumiram as posições dominantes (coordenadores, técnicos, assessores), enquanto os não médicos permaneceram nas posições menos qualificadas ao interior do aparelho estatal (técnico-administrativos).

Alguns dos agentes que tiveram importante participação na gênese e nas transformações do espaço aids tiveram uma trajetória política dominante. Não apenas através da filiação a partidos políticos, mas chegando a cargos eletivos, como o médico pediatra e ministro Carlos Sant'Anna e o médico sanitarista Sérgio Arouca, que foram eleitos deputados federais, ou aqueles que como Herbert Daniel, da Abia, concorreram, sem sucesso, a cargos eletivos.

Outros tiveram participação no movimento sanitário como E9, E10, E26, E27 e Paulo Bonfim, do Gapa; no movimento homossexual, a exemplo de E18, E8, E20, E33 e E26; na luta contra ditadura, participando de movimentos como a Ação Popular (AP) ${ }^{35}$ ou de partidos clandestinos como o Partido Comunista Brasileiro (PCB). ${ }^{36}$ Além disso, houve participações mais periféricas - não dominantes - na Convergência Socialista e, em especial, na fundação do Partido dos Trabalhadores (PT). A maioria dos agentes que possuía algum volume da capital político teve papel de destaque no espaço militante, assumindo posições dominantes, como a direção das ONGs/Aids ou outras organizações associativas.

E4 e E12 militaram no PCB. 
Contudo, o objeto em questão era a luta contra aids. A discussão era de políticas públicas que pudessem intervir na epidemia, não se tratando de política partidária. $\mathrm{O}$ apoio poderia vir de diferentes correntes políticas que abraçassem a causa e apoiassem as propostas da organização. Isso também não significava que os sujeitos não pudessem ser filiados a partidos políticos, contudo, evitava-se uma vinculação da instituição àquelas da política tradicional, bem como um posicionamento da instituição ou de seus membros na política partidária.

[...] uma vez que eu estava fazendo um curso para magistratura, e o professor chamava 'esses aidéticos baderneiros, não sei o que, esse movimento petista' e eu ficava pensando, mas meu Deus do céu, já não se fala mais assim há tanto tempo [...] um dia eu fuifalar com ele, aí ele falou: 'Não, para mim éassim, vocês estão dentro disso ai', que ele ainda foi bem agressivo, e era desembargador. 'Para vocês que são petistas...' Eu falei: 'Mas eu não sou petista'. Aíele falou: 'mas não, só pode ser petista para fazer essa baderna'. O trabalho que a gente considerava sério para eles era baderna. E também aqui dentro [da associação] nunca se tratou de política. Então podia vir como veio, o Ítalo, como veio a Rita de Cardoso, como veio outros, a Luisa Erundina, antes dela ser prefeita e antes dela ser deputada. Agente tinha os encontros. Mas você não tratava de política partidária e sim de política de saúde. Então, na cabeça da gente, isso estava muito claro. Nem bandeirola no carro, nem nada [...]. (E3)

Da mesma forma, o sociólogo Herbert de Souza, fundador da Abia, ainda que com uma trajetória militante importante, desde a adolescência tendo participado do movimento da Juventude Católica, do movimento estudantil, da fundação da Ação Popular (AP), do movimento operário e tendo sido exilado político, recusava-se a integrar a política partidária institucionalizada. Sua atuação era voltada para associações como Instituto Brasileiro de Análises Sociais e Econômicas (Ibase) e Abia.

Foram identificadas cinco concepções sobre a aids (Quadro 4):

1. A aids foi considerada como "uma doença", uma infecção, ou uma epidemia, o que correspondia a uma definição mais técnica, principalmente pelos agentes do campo burocrático; 
QUADRO 4-Concepções sobre a aids segundo agentes estudados, de acordo com subespaço de pertencimento, ano de entrada no espaço aids, sexo e formação

\begin{tabular}{|c|c|c|c|}
\hline Concepção sobre aids & Agente & Subespaço & Evidências nas entrevistas ou documentos \\
\hline \multirow[t]{7}{*}{ Doença/ Epidemia } & E1 & Burocrático & "É uma doença [...] era uma epidemia." \\
\hline & E10 & Burocrático & "É uma infecção pelo vírus HIV." \\
\hline & E11 & Burocrático & $\begin{array}{l}\text { "É uma doença, acho que é uma doença importante do ponto de vista biológico, } \\
\text { médico. [...] acho que é a doença do nosso século, tal como era a tuberculose no } \\
\text { passado." }\end{array}$ \\
\hline & E9 & Científico & "É uma doença que veio pra ficar. [...] É mais uma doença, só que tem estrela." \\
\hline & E15 & Burocrático & "É uma epidemia que começou tão pequena e que hoje está em todos os lugares." \\
\hline & E31 & Científico & $\begin{array}{l}\text { "Hoje, é uma doença como as outras [...], mas é um tratamento que ainda tem que } \\
\text { ser aperfeiçoado [...]." }\end{array}$ \\
\hline & E21 & Burocrático & $\begin{array}{l}\text { "É uma doença adquirida [...] As pessoas que não são contaminadas por acidente, } \\
\text { tipo transfusões de sangue, elas vão atrás, ou seja, relações de risco. Para mim a } \\
\text { aids fez o que eu sou hoje profissionalmente." }\end{array}$ \\
\hline \multirow{7}{*}{$\begin{array}{l}\text { Doença relacionada } \\
\text { a morte, ao perigo, } \\
\text { a reações de pânico, } \\
\text { pavor e medo, estigma } \\
\text { e discriminação }\end{array}$} & E3 & Militante & "No primeiro ano, se eu não perdi 30 amigos, eu perdi pouco." \\
\hline & E29 & Militante & "Uma epidemia causada por um vírus, que causava uma doença devastadora." \\
\hline & E18* & Militante & $\begin{array}{l}\text { "[...] a aids tem várias dimensões. [...] eu acho que na atualidade ocupa menos } \\
\text { espaço [...] porque entrou em uma estabilidade [...] Agora, continua carregado de } \\
\text { muito estigma, discriminação [...]" }\end{array}$ \\
\hline & $E 33^{*}$ & Militante & "E ela é preconceito, é discriminação ainda. [...] Mas também uma oportunidade." \\
\hline & E7 & Científico & $\begin{array}{l}\text { "Era uma coisa muito grande, perigosa, um risco enorme para a humanidade [...] } \\
\text { Hoje é o exemplo da capacidade do ser humano de se superar." }\end{array}$ \\
\hline & E31 & Científico & $\begin{array}{l}\text { "[...] Ela foi horrível! Ela foi o pior pesadelo, um pesadelo que não terminava. E que } \\
\text { só deixou de ser pesadelo quando a gente percebeu que se passaram } 20 \text { anos e as } \\
\text { pessoas que a gente atendeu há muito tempo não morreram. [...]." }\end{array}$ \\
\hline & E4 & Científico & $\begin{array}{l}\text { "Foi um mal muito grande, mas no bojo desse mal muitas coisas aconteceram. } \\
\text { [...] a aids trouxe coisas horrorosas, terríveis devastadoras, mas ao mesmo tempo } \\
\text { forçou a sociedade a se organizar para combatê-la." }\end{array}$ \\
\hline \multirow{4}{*}{$\begin{array}{l}\text { Problema social ou de } \\
\text { saúde pública }\end{array}$} & E15 & Burocrático & "[...] ainda é um desafio para a saúde pública." \\
\hline & E18* & Militante & $\begin{array}{l}\text { "[...] a aids tem várias dimensões. [...] eu acho que na atualidade ocupa menos } \\
\text { espaço [...] porque entrou em uma estabilidade [...]" }\end{array}$ \\
\hline & E33* & Militante & $\begin{array}{l}\text { "É uma doença, mas é uma crise porque ela envolve tantas questões morais, } \\
\text { políticas, sociais, culturais, que entram em xeque com a epidemia." }\end{array}$ \\
\hline & $E 8^{*}$ & $\begin{array}{l}\text { Militante/ } \\
\text { Científico }\end{array}$ & $\begin{array}{l}\text { "Era uma coisa muito forte, muito grande, é uma doença que tem um monte de } \\
\text { conotações políticas, culturais, virou do ponto de visto das pessoas uma doença } \\
\text { crônica, mas eu acho que é mais sério do que isso." }\end{array}$ \\
\hline \multirow[t]{4}{*}{ Problema de pesquisa } & $\begin{array}{l}\text { Herbert } \\
\text { de Souza }\end{array}$ & Militante & $\begin{array}{l}\text { "É uma doença que desafia e que diz para a ciência o seguinte: ou você me decifra } \\
\text { ou eu te engulo." (SOUZA, H. Memória Roda Viva: Debate aids. 19/01/1987: 1-57 } \\
\text { p. 1987) }\end{array}$ \\
\hline & $E 4$ & Científico & "[...] forçou a sociedade a se organizar para combatê-la." \\
\hline & E30 & Científico & $\begin{array}{l}\text { "Hoje, é uma doença como as outras [...], mas é um tratamento que ainda tem que } \\
\text { ser aperfeiçoado[..." }\end{array}$ \\
\hline & E7 & Científico & $\begin{array}{l}\text { "Era uma coisa muito grande, perigosa, um risco enorme para a humanidade [...] } \\
\text { Hoje é o exemplo da capacidade do ser humano de se superar." }\end{array}$ \\
\hline $\begin{array}{l}\text { Ameaça à liberação } \\
\text { sexual }\end{array}$ & $E 20^{*}$ & Militante & "[...] a aids foi um balde de agua fria na fervura da liberação sexual dos anos $80 . "$ \\
\hline
\end{tabular}

Fonte: Elaborado pela autora.

Nota: *Participantes do movimento homossexual. 
2. Alguns agentes dos três subespaços também a definiram como "um problema social ou de saúde pública”, mantendo o caráter técnico trazido na concepção dos agentes do campo burocrático, mas acrescentando um caráter social e a responsabilização do Estado e/ ou da sociedade;

3. Agentes do espaço militante e do campo científico, envolvidos desde os primeiros momentos na luta contra a epidemia, a definiram como "uma doença relacionada à morte, ao perigo, a reações de pânico, pavor e medo, estigma e discriminação". Essa visão pode ser evidenciada também em diversos trechos das entrevistas apresentados ao longo deste livro;

4. Para os agentes do campo científico, a aids era "um problema de investigação", relacionado ao desconhecimento então existente naquele período acerca da doença. Essa concepção também era partilhada pelo sociólogo Herbert de Souza, fundador da Abia;

5. Outra concepção identificada foi a de "uma ameaça à liberação sexual”, manifestada por um militante do movimento homossexual.

Apesar de não comungarem da mesma visão sobre o que é a aids e, consequentemente, das medidas a serem adotadas para o seu enfrentamento, essa diversidade de concepções contribuiu para uma complementaridade, de modo que o problema foi construído de forma ampla e as ações baseadas na dignidade dos doentes e nos direitos humanos. Nesse sentido, a Comissão Nacional de Aids, como instância estatal, na qual os poderes científico e militante estavam concentrados e transmutados em poder burocrático de normalização, teve importante papel na construção de um discurso oficial que contemplasse a negociação entre os agentes dos diferentes subespaços.

A partir da criação desse novo espaço de lutas, dos enfrentamentos entre os agentes desses diferentes subespaços com a chegada do processo de redemocratização ao governo federal e eleições para presidente da república marcadas para janeiro de 1985, bem como a ocorrência de casos de aids para além do eixo Rio-São Paulo, que começaram a surgir as 
primeiras medidas mais específicas para o controle da epidemia e a implantação de uma política nacional de luta contra a aids no país.

\section{A resposta do Ministério da Saúde}

Nos primeiros anos da epidemia, o governo federal quase não se pronunciava, mas também não era questionado pela imprensa e pela comunidade científica. Durante o $20^{\circ}$ Congresso da Sociedade Brasileira de Medicina Tropical, realizado em 1984, em Salvador, a aids ainda não era vista como um problema a ser priorizado pelo Ministério da Saúde.

Em 1984, a comunidade acadêmica já sabia sobre a expansão da doença nos EUA, mas não entendia que era ainda um problema brasileiro. Me lembro de ter ido a um congresso de DST em Salvador com Paulo Teixeira, de São Paulo, e planejamos uma intervenção plenária para falar do problema e a possibilidade de se tirar uma carta ao Ministério da Saúde. Quase fomos vaiados. Na verdade apenas as SES de São Paulo, Rio Grande do Sul e Rio de Janeiro começavam a se organizar tendo como modelo São Paulo. (E24) ${ }^{37}$

A Folha de São Paulo, no período de 1983 e 1984, não divulgou notícias relacionando o Ministério da Saúde e a epidemia da aids. As notícias veiculadas sobre a epidemia concentravam-se na ocorrência de casos em São Paulo, estado com maior número de pessoas acometidas pela aids no país, e eventualmente nos demais estados; nas ações do Programa de Aids da SES-SP; e em notícias vindas do exterior. ${ }^{38}$ Há o registro de que, em junho de 1983, o Ministério da Saúde elaborou um documento denominado "Aids - informações básicas" que reunia o resumo de alguns artigos publicados no exterior, falava da epidemia nos EUA, mas não fazia referência aos casos brasileiros, que já estavam sendo divulgados pela imprensa médica e também pela imprensa leiga. (TEIXEIRA, 1997)

Mensagem pessoal enviada porE24, médica egestora. Mensagem recebida por <sgb@ufba.br> em 12 abr. 2012.

38 Consulta ao acervo on line da Folha de São Paulo, disponível em <http://acervo.folha.com. br/>, para o período entre 01/01/1983 e 15/03/1985. 
O Departamento de Dermatologia Sanitária do Ministério da Saúde, 1983, 1984, principalmente, tinha uma posição muito reticente, até de oposição. Considerando que não era um agravo de saúde pública que explicasse as ações que estavam sendo feitas, e com as Dermatologias se envolvendo, isso trazia para o âmbito do Ministério uma determinada agitação em relação ao tema. [...] foi uma posição decrítica. (E26)

A situação no Ministério da Saúde começou a mudar em 1985. “Até então, seus representantes se pautaram por minimizar a dimensão do problema e criticar as ações programáticas adotadas pelas diversas unidades federadas". (TEIXEIRA, 1997, p. 55)

No final do período da ditadura militar, após a realização de eleições indiretas para presidente da república emjaneiro 1985 e da eleição de Tancredo Neves, do PMDB, as ações relacionadas ao controle da epidemia da aids, no governo federal, iniciaram-se no âmbito do Programa Capacitação de Recursos Humanos para o Controle de Infecções Hospitalares, ${ }^{39}$ coordenado pelo Dr. Luiz Carlos Pelizari Romero, da Secretaria Nacional de Programas Especiais de Saúde (SNPES). Embora o programa houvesse iniciado no final de 1983, a primeira reunião relacionada à aids aconteceu em fevereiro de 1985, ainda nos últimos meses do governo Figueiredo. O Ministro da Saúde era Waldyr Mendes Arcoverde ${ }^{40}$ e Fabíola de Aguiar Nunes, médica baiana, sanitarista, com trajetória profissional em diferentes níveis da burocracia estatal da saúde, ocupava, naquele momento, um cargo no Ministério da Educação e Cultura (MEC) e também participava do programa como sua representante..$^{41}$

O Projeto Capacitação de Recursos Humanos para Controle da Infecção Hospitalar foi instalado em fins de 1983 pelo Ministério da Saúde. Seu primeiro encontro de avaliação aconteceu entre os dias 16 e 19 de dezembro de 1985. (INFECÇÃO..., 1985)

Médico sanitarista, foi Ministro da Saúde no período de 30/01/1979a 14/03/1985, pretendia interiorizar as ações básicas de saúde nas regiões mais pobres, na sua gestão tiveram início as pesquisas na Fiocruz para o desenvolvimento de uma vacina contra o sarampo.

41 "[... ] na troca do governo, eu tinha participado enquanto MEC da elaboração do programa nacional de controle de infecção hospitalar que o ministério da saúde fez e não usou. [...] analisar o problema de infecção hospitalar é complicado e ninguém sabia nada, só que estava matando, não adiantava a vigilância sanitária, tinha que começar com um treinamento. O que é que o ministério fez? Ainda estava nas AIS, era uma ação interministerial e eu entrei pelo 
Tancredo Neves não chegou a assumir a presidência, mas o vice-presidente, José Sarney, manteve inicialmente os ministros por ele escolhidos. Carlos Sant'Anna, médico pediatra, deputado baiano pelo PMDB eleito em 1982, antes eleito pela Aliança Renovadora Nacional (ARENA) em 1978, e um dos articuladores da campanha de Tancredo, assumiu o Ministério da Saúde, tomando posse em 15 de março de 1985.

Quando Carlos Sant'Anna assumiu o Ministério, Fabíola de Aguiar Nunes foi convidada a assumir a Secretaria Nacional de Programas Especiais de Saúde (SNPES), no Ministério da Saúde, no qual, no âmbito da Divisão Nacional de Dermatologia Sanitária (DNDS), seria criado o Programa Nacional de DST/Aids. A indicação de Fabíola Nunes, ainda que essa fosse companheira de Carlos Sant'Anna, veio do Secretário de Estado de Saúde de São Paulo, João Yunes. (E1O) ${ }^{42}$ O responsável pela DNDS era o médico dermatologista Aguinaldo Gonçalves, ${ }^{43}$ que foi mantido inicialmente no cargo. No início, a nomeação da esposa do ministro para a secretaria foi criticada na imprensa. (A MULTIPLICAÇÃO..., 1985) As primeiras ações realizadas pelo Ministério da Saúde, em 1985, estavam relacionadas à definição de casos e, principalmente, com a criação

MEC. Se fez uma proposta nacional de treinamento de profissionais de saúde de hospitais, começando com os de grande porte. [...] Eu participei desse negócio todo nos bastidores, caladinha láno MEC. [...] Quando chegou no mês de janeiro, que Tancredo tinha ganho, a posse ia ser em março. Não sei se você se lembra disso. Foram três meses, Tancredo eleito e os militares, aí, foi uma orgia de jogar dinheiro fora, para a nova república chegar sem dinheiro. No MEC também. Eu chamei Dr. Romero, que hoje está no senado, e naquela época estava no ministério da saúde [...] Conseguimos todo o dinheiro, entre janeiro e março a gente treinou 12 hospitais no centro de treinamento, criou todos os manuais." (E10, entrevista concedida à profa. Ligia Maria Vieira da Silva, em 12/11/2008, Projeto Espaço da Saúde Coletiva)

Entrevista concedida por E10, em Salvador, em 14 de julho de 2011.

Aguinaldo Gonçalves nasceu em 18 de agosto de 1949, em Santos, São Paulo. Médico formado pela Unesp (em 1967), especialista em Medicina de Trabalho (1974), Saúde Pública (1976) pela USP. mestre (1977) e doutor (1980) em Ciências Biológicas (Biologia Genética), também na USP (1977). Professor de Epidemiologia, Dermatologia Sanitária e Controle da Hanseníase da Faculdade de Saúde Pública da USP entre 1977-1980. Foi convidado pelo ministro da Saúde, Waldyr Arcoverde, para trabalhar como diretor da Divisão Nacional de Dermatologia Sanitária, a partir de 1980. Ao deixar essa função, entre 1986 e 1988, atuou como analista de desenvolvimento científico no CNPq. Recebeu a medalha de mérito "Vacuna contra la Lepra"(1983), concedida pela Asociación para la Investigación Dermatológica, em Caracas, Venezuela. Em 1988 tornou-se professor titular em Saúde Coletiva da Faculdade de Educação Física, da Universidade de Campinas (Unicamp), São Paulo. (MACIEL; OLIVEIRA; GALLO, 2010, p. 34-36) 
de um sistema de vigilância epidemiológica para a aids. Participaram das primeiras reuniões o coordenador do Programa Estadual de DST/Aids de São Paulo, Paulo Roberto Teixeira, o médico Vicente Amato Neto, ${ }^{44}$ professor de infectologia da USP, e técnicos de outros estados. (E1O; E11; E24) A $1^{\text {a }}$ reunião foi realizada no dia 14 de fevereiro de 1985 , no último mês do governo militar, no Ministério da Saúde, com a comunidade científica. Teve como objetivo revisar a literatura especializada sobre aids e como resultado a minuta da portaria para controle da infecção hospitalar em pacientes com aids.

Àquela altura já havia uma reivindicação dos movimentos sociais, não apenas de homossexuais, mas também de talassêmicos e hemofílicos, cobrando uma resposta do governo; a imprensa falava insistentemente do assunto (E10; E26) e, além de São Paulo, os estados do Rio de Janeiro e Rio Grande do Sul já tinham estruturado algumas ações (E24), também pressionando o governo federal a tomar uma decisão. Some-se ainda a representação social da doença, associada ao pavor e ao medo.

A imprensa enfatizava a mortalidade, o grupo de risco (homossexuais) e o desconhecimento da doença, mas ainda não havia critério diagnóstico definido.

$\mathrm{Na}$ ocasião que eu estou falando, não se sabia nada. Era uma doença nova que tinha uns sintomas muito agudos, quer dizer, a pessoa adquiria aquela doença, começava a ter febre alta, emagrecimento excessivo, muita diarreia, uma indisposição terrível e geralmente quem tinha essa doença em 6 meses estava morto. Esse era o quadro. O próprio CDC [Centers for Disease Control and Prevention, EUA] em março de 1985, não tinha uma definição de caso clara, nem um critério de diagnóstico. O critério de diagnóstico era clínico. [...] Quando nós assumimos, tinham duzentos e setenta e dois casos, metade diagnosticado nos últimos dois anos, e a outra metade nos últimos dois meses. (E10) a partir de 1977. Diagnosticou o primeiro caso de aids autóctone brasileiro (1982). Presidiu durante vários anos a Comissão de Aids da Secretaria da Saúde do estado de São Paulo. Foi membro e secretário executivo da Comissão Nacional de Aids. 
Foram realizadas reuniões em São Paulo (13 a 15/03/ 1985) e Brasília (27 a 29/03/1985) com o objetivo de revisar e discutir os casos diagnosticados até aquele momento, tendo como produtos, respectivamente, a normalização de procedimentos no manejo da aids e a redação, por um grupo de especialistas nacionais, da minuta da portaria ministerial, ${ }^{45}$ que definiu critérios diagnósticos e estratégias de ação para o controle da epidemia de aids no país. (BRASIL, 1985b) Propunha-se a investigação epidemiológica, clínica, laboratorial e educação sanitária de casos suspeitos e confirmados, bem como de comunicantes e a realização de programa de educação sanitária para grupos em risco - homossexuais e bissexuais masculinos, usuários de drogas injetáveis, hemofílicos ou politransfundidos. A portaria mencionava o uso de preservativo, a utilização de seringas e agulhas descartáveis ou de uso individual e o controle da qualidade do sangue como medidas preventivas. (BRASIL, 1985b) Além disso, foi organizado um sistema para que todos os estados que ainda não tinham casos notificados, à medida que esses fossem sendo identificados, enviassem representantes para serem treinados em São Paulo. (E1O; E26) (BRASIL, 1985a)

Em meados de 1985, a Dermatologia Sanitária da Secretaria de Saúde do Estado do Rio de Janeiro (SES-RJ) também começou a organizar o seu programa estadual. Foi criada a Comissão Interinstitucional de Combate e Controle da Aids no estado do Rio de Janeiro. O governador era Leonel Brizola, fundador do Partido Democrático Trabalhista (PDT), eleito pelo voto direto em 1982, e o secretário de Saúde do Estado era Eduardo Azeredo Costa, médico com doutorado pela London School of Hygiene

A portaria n. 236, assinada no dia 2 de maio de 1985, criou o programa de controle da aids, delegando à DNDS a coordenação, determinando as medidas de prevenção a serem adotadas no país junto a comunicantes e casos confirmados (indivíduo que, pertencendo a algum grupo de risco, apresente uma ou mais das seguintes entidades mórbidas: 1- Sarcoma de Kaposi, em indivíduos com menos de sessenta anos de idade; 2-Linfoma limitado ao cérebro;3-Pneumonia por Pneumocystis; 4- Toxoplasmose, causando pneumonia ou infecção do sistema nervoso central; 5- Strongiloidiase, causando pneumonia, infecção do sistema nervoso central ou infecção generalizada; 6- Candidíase, causando esofagite; 7- Criptococose, causando infecção pulmonar, do sistema nervoso central ou disseminada; 8- Micobacterioses atípicas, comprovadas através de cultura; 9- Infecções causadas por citomegalovírus no pulmão, no trato gastrointestinal, sistema nervoso central, supra-renal e pâncreas; 10- Infecções por vírus herpes, tipo um ou dois, mucocutâneas (com úlceras que persistem por mais de um mês), pulmonares, do aparelho digestivo, ou disseminadas; 11- Leucoencefalopatia multifocal progressiva. 
\& Tropical Medicine. A médica dermatologista Maria Leide Wan del Rey de Oliveira ${ }^{46}$ coordenava o Programa Estadual de Dermatologia Sanitária desde 1983 e trabalhou na organização do Programa Estadual de Aids, com apoio do Hospital Universitário Clementino Fraga Filho (HUCFF), onde eram atendidos os casos suspeitos, e do laboratório da Fiocruz, que fazia o teste Elisa. Após um treinamento em Doenças Sexualmente Transmissíveis (DST) promovido pela OPAS, em Porto Rico, do qual ela participou junto com Paulo Roberto Teixeira, de São Paulo, Aguinaldo Gonçalves, da DNDS, e um médico de referência de Brasília, Maria Leide Wan del Rey de Oliveira elaborou o plano que levou à ampliação da equipe da Dermatologia Sanitária do Rio de Janeiro. Ampliação essa que permitiu a entrada do médico sanitarista Álvaro Matida no Programa Estadual de Aids, substituindo Cláudio Amaral na presidência da Comissão. Colaboraram com o Programa de Aids da SES-RJ os grupos homossexuais Triângulo Rosa e, a partir de 1986, o Atobá. (FATAL, 1988)

Ainda assim, o Ministro da Saúde, Carlos Sant'Anna, seguia afirmando: “trata-se de uma doença preocupante, mas não prioritária”, destacando a existência de outras doenças de maior prevalência como Chagas, hanseníase e esquistossomose (A MULTIPLICAÇÃO..., 1985, p. 56), visão que pode ter limitado a resposta inicial do governo federal, principalmente em relação aos recursos financeiros, ainda que a política nacional tenha sido implantada precocemente quando comparada à realidade de outros países.

No início de 1986, devido a divergências acerca da política de controle de hanseníase conduzida por Aguinaldo Gonçalves, Fabíola Nunes convidou Maria Leide Wan del Rey de Oliveira para assumir a Divisão Nacional de Dermatologia Sanitária (DNDS). (E10; E24)

Quando Maria Leide chegou à DNDS, em janeiro de 1986, existia uma técnica responsável pela aids, médica veterinária e sanitarista, mas não existiam condições de trabalho, nem orçamento. Maria Leide convidou inicialmente Miriam Franchini, que trabalhava com DST em Brasília, e

46 Maria Leide Wan del Rey de Oliveira, médica dermatologista, servidora do Inamps e professora da UFRJ, que participou do Movimento Popular de Saúde e fundou o $1^{\circ}$ núcleo do Movimento de Reintegração das Pessoas atingidas pela Hanseníase (Morhan) no Rio de Janeiro, era coordenadora do Programa Estadual de Dermatologia Sanitária do Rio de Janeiro. (OLIVEIRA, 2008) 
Lúcia Amaral, “uma sanitarista recém-saída da Fiocruz, que foi nosso braço direito na aids inicialmente e grande responsável pelo sistema de notificação inicial". (E24) Miriam Franchini ficou responsável pelas doenças sexualmente transmissíveis. (OLIVEIRA, 2008) Lair Guerra de Macedo Rodrigues, biomédica, professora da UnB, que havia feito especialização nos Centers for Disease Control and Prevention (CDC) nos EUA, e trabalhava no Programa de Saúde da Mulher foi convidada por Maria Leide para assumir a aids devido a uma palestra que havia assistido em $1984 \mathrm{du}-$ rante $\mathrm{o} 20^{\circ}$ Congresso da Sociedade de Medicina Tropical, no qual ela falava da experiência nos CDC; às boas referências sobre o seu trabalho; o fato de que ela estava saindo do Programa de Saúde da Mulher; e a possibilidade de influência e apoio internacional visto que a mesma era irmã de Carlyle Guerra de Macedo, representante da Organização Panamericana de Saúde (OPAS). Segundo Maria Leide, na mesma semana em que foi convidada, Lair Guerra entrou na sua sala dizendo: "Carlyle me disse que você colocou em minha mão uma missão de trabalho para o Brasil”. (E24)

Foi também com a entrada de Maria Leide na DNDS que teve início o comitê de grupos de risco e depois a Comissão Nacional de Aids, que serão detalhados mais adiante. Na minuta que deu origem à portaria $\mathrm{n}^{\circ}$ 236/1985, que oficialmente criou o programa nacional, existia um item denominado "Componentes do Programa de SIDA/AIDS", que propunha a criação de uma Comissão Interinstitucional nos estados, incluindo representantes da secretaria de saúde, Inamps, hospitais universitários, Pró-Sangue e outros serviços relacionados. A sua função seria coordenar as atividades de controle da aids, coletar dados, selecionar e avaliar o programa local, em consonância com as diretrizes nacionais. Esse item, contudo, não consta da portaria publicada no Diário Oficial da União.

Assim, para a decisão política e o desenvolvimento de uma política de controle da epidemia da aids contribuíram agentes que não estariam expostos ou não se importariam de se expor a interrogações acerca de uma eventual homossexualidade, como aconteceu com Michèle Barzach, na definição da política de aids na França. (PINELL et al., 2002) Ou seja, mulheres, como Fabíola Nunes e Lair Guerra, ou um ex-militante do movimento homossexual, como Paulo Roberto Teixeira. 
As articulações internacionais de Lair nos CDC e na OPAS, assim como sua capacidade de gestão ajudaram na estruturação inicial e ampliação do Programa de DST/Aids. Este também contou com uma colaboração importante da Fundação Serviços Especiais de Saúde Pública (FSESP) para a sua interiorização, ${ }^{47}$ através de seu representante para doenças transmissíveis, o médico sanitarista Pedro Chequer, que em seguida iria integrar também a equipe do Programa Nacional. (OLIVEIRA, 2008)

\section{A aids, a $8^{\text {a }}$ Conferência Nacional de Saúde e a Assembleia Nacional Constituinte}

Após entrar na agenda do Ministério da Saúde, a aids foi incluída em um

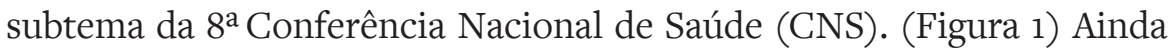
que o relatório específico não tenha sido localizado, como desdobramento das discussões na $8^{\text {a }} \mathrm{CNS}$ foram realizados debates em diversos estados, sob a coordenação do Ministério da Saúde, para se discutir o tema "Aids e Constituinte", sendo o primeiro realizado em Belo Horizonte, ainda em agosto de 1986. (BRASIL, 1986b; MÉDICO..., 1986; TEIXEIRA et al., 1987) Os debates tinham o objetivo de discutir como o novo sistema de saúde poderia resolver o problema da aids. Essas discussões inclusive pautaram a campanha nacional lançada em 1987. (TEIXEIRA et al., 1987)

Além de constar no subtema "Vigilância Epidemiológica (grandes endemias, doenças evitáveis por imunização e AIDS)", a aids também estava relacionada à mobilização do subtema "Sangue e Hemoderivados". Foi a contaminação pelo HIV através de transfusão sanguínea de talassêmicos, renais crônicos e, em especial, hemofílicos que reforçou a necessidade de controle da qualidade do sangue no país. Na década de 1980, não havia qualquer controle sobre o comércio de sangue e hemoderivados, sendo estes importantes veículos de transmissão de doenças. Diversas pessoas submetidas à transfusão foram contaminadas e morreram, sendo um dos mais famosos, o cartunista Henfil, irmão de Betinho. (SANTOS; MORAES; COELHO, 1992)

47 A FSESP organizou treinamentos em hanseníase e doenças sexualmente transmissíveis para as suas unidades, iniciando pelo Centro de Referência Alfredo da Matta, em Manaus, com os médicos Adele Benzaken e José Carlos Sardinha. (OLIVEIRA, 2008) 
FIGURA 1 - Recorte do Regimento especial da 8 a Conferência Nacional de Saúde e Cartaz Aids e a Constituinte

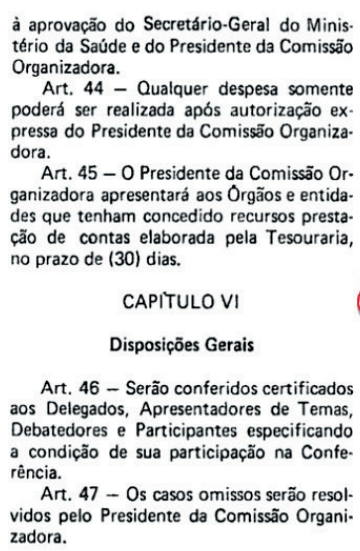

8ạ CONFERENCIA NACIONAL DE SAÜDE TEMARIO

Temas Básicos

1 - Saúde como Direito Inerente à Cidadania e à Personalidade

2 - Reformulação do Sistema Nacional de

Saúde

3 - Financiamento do Setor Saúde

Temas Especificos

1 - Saude e Trabalho

2 - Vigilância Epidemiológica (grandes en

demias, doenças evitáveis por imunização,

AIDS)

3-Saúde e Sistema Ecológico

4 - Saúde, Produção e Distribuição de Ali-

mentos

5 - Niedicamentos e Imunobiológicos

6. Saúde-Ora

7 - Sangue e Hemoderivados

8 - Reproduçäo Humana

9 - Práticas Alternativas de Saúde

10 - Recursos Humanos

11 - Saúde e Políticas Sociais

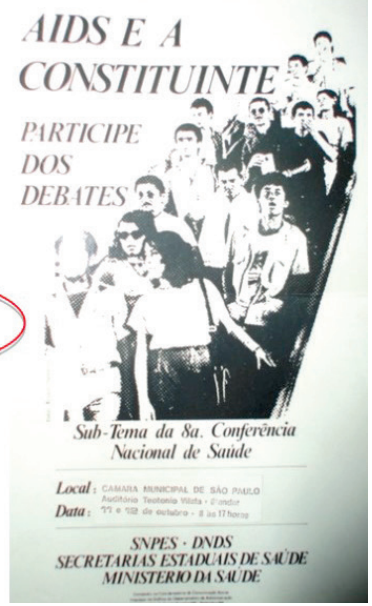

Fonte: Esquerda: Conferência Nacional de Saúde (1986, p. 408). Direita: Brasil (1986a).

No início, os hematologistas e o Estado mantiveram um discurso de minimizar o problema. Os primeiros contemporizando que o principal problema para os hemofílicos "não é a transmissão da doença pelo sangue, mas sim a falta de sangue". (NO RIO..., 1985, p. 13) O segundo alegando falta de recursos ou contestando o tamanho da amostra utilizada no relatório da Divisão Nacional de Sangue e Hemoderivados, que sugeria que 70 a $84 \%$ dos hemofílicos do eixo Rio-São Paulo estariam contaminados. (PROGRAMA..., 1987; TEIXEIRA..., 1985) Contudo, o Boletim Epidemiológico n. 5 de 1987 trazia recomendações, ainda que insuficientes para o controle do sangue no país, tais como: não aceitar candidatos à doação remunerada, nem provenientes de casas de detenção ou colônias de recuperação de drogaditos ou expostos a fatores de risco; realizar busca de manifestações da doença ao exame físico; implantar sistema de autoexclusão, entre outros. ${ }^{48}$

As associações específicas de luta contra a aids, que surgiram a partir de 1985, tiveram papel determinante para a regulamentação do controle 
do sangue e hemoderivados no Brasil, constituindo em 1988, o comitê "Pacto de Sangue", uma iniciativa que congregava diversas entidades que ofereciam apoio jurídico na promoção de ações contra o Estado, hospitais e clínicas onde havia ocorrido contaminação. (SANTOS; MORAES; COELHO, 1992) A Associação Brasileira Interdisciplinar de Aids (Abia), tendo o sociólogo Herbert de Souza, um hemofílico, na sua direção, realizou uma mobilização que tinha como slogan: "Salve o sangue do povo brasileiro”. As principais condições para a organização dessa mobilização foram: a importância da questão do sangue para o movimento sanitário, a participação de sanitaristas no conselho diretor da Abia, a emergência da epidemia da aids, assim como as discussões e elaboração de uma nova constituição. (PARKER; TERTO JUNIOR, 2001) Da mesma forma, Paulo Bonfim, do Gapa, envolveu-se nessa questão. (CONTRERA, 2000) Ambos inclusive foram a Brasília para fazer lobby junto à assembleia constituinte.

Em 25 de janeiro de 1988, a Lei n. 7.649 estabeleceu a obrigatoriedade do cadastro dos doadores de sangue e da realização de testes de laboratório para hepatite $\mathrm{B}$, sífilis, doença de Chagas, malária e aids. O projeto de lei foi apresentado em outubro de 1985 pelo Senador Gastão Muller, do PMDB do Mato Grosso, e teve como relator o deputado Carlos Sant'Anna. A assinatura da lei aconteceu dias após a morte do famoso cartunista Henfil, em 4 de janeiro de 1988. Sua morte levou a inúmeras manifestações e protestos em todo o país, de modo que a lei ficou também conhecida como "Lei Henfil." (BRASIL, 1988b) Esta lei foi regulamentada pelo Decreto 95.721, de 11/02/1988.

Em outubro, a nova constituição proibiu a comercialização do sangue e hemoderivados no país. (BRASIL, 1988a, Art. 199, §40) Tiveram importante papel nessa discussão na assembleia constituinte Sérgio Arouca, então presidente da Fiocruz, e o deputado federal Carlos Sant'Anna fazendo a defesa do dispositivo nos dois turnos de votação. Carlos Sant'Anna, embora fosse chefe do governo na Câmara dos Deputados, fez a defesa na condição de médico, contrapondo-se à posição do então Ministro da Saúde, Borges da Silveira. (SOUZA, 1988) A partir daí, o Ministério da Saúde elaborou as normas técnicas para a hemoterapia no país, através da Portaria n. 721 de 11/08/1989. Contudo, o projeto de lei para regulamentação desse parágrafo da constituição foi apresentado em 1991, pelo 
deputado Roberto Jefferson, do PTB do Rio de Janeiro, mesmo tendo regime de tramitação de urgência, apenas dez anos depois, em 2001, foi aprovada a Lei 10.205, que regulamentou a coleta, processamento, estocagem, distribuição e aplicação do sangue, componentes e derivados e proibiu o comércio desses materiais no Brasil. Pelo envolvimento do sociólogo Herbert de Souza nessa luta, a lei é conhecida como "Lei do Sangue" ou "Lei Betinho". (BRASIL, 2001b)

\section{A construção de uma identidade: a saída da dermatologia sanitária}

A concepção de Fabíola Nunes e Maria Leide acerca da posição do programa na estrutura do Ministério divergia daquela defendida por Lair Guerra, que considerava que o programa de aids ao interior da Divisão Nacional de Dermatologia Sanitária (DNDS) ficava limitado à dermatologia e que esse deveria se dissociar da divisão para ampliar seu leque de ações. Fabíola Nunes e Maria Leide de Oliveira consideravam que para antes desse desligamento seria necessária uma negociação com a Sociedade Brasileira de Dermatologia. (E10) Essas divergências traduziam disputas entre agentes do campo médico (Fabíola Nunes e Maria Leide), preocupadas com as disputas também desse campo, e uma agente do espaço aids (Lair Guerra), um espaço emergente que começava a se consolidar e buscar uma certa autonomia.

Ao final de 1986, havia discordâncias também entre a secretária Fabíola Nunes e o ministro Roberto Santos acerca da situação sanitária do país. Para o ministro, o Brasil estava respondendo bem ao avanço da epidemia e estava adotando providências para reduzir a sua incidência. (SECRETÁRIA..., 1986) Na visão de Fabíola, Roberto Santos “estava contra a reforma sanitária" (E10) e o avanço da aids evidenciava as fragilidades do setor de saúde e sua incapacidade de resposta à doença. A situação teria se agravado com uma ocorrência relacionada à campanha de vacinação contra o sarampo, devido a declarações de Fabíola Nunes à imprensa que desagradaram o ministro. Sua exoneração, contudo, ainda foi adiada para depois da visita de Jonathan Mann, diretor do Programa 
de Aids da OMS, ao Brasil em 1987, ${ }^{49}$ em função da nomeação de Carlos Sant'Anna como líder do governo na Assembleia Nacional Constituinte. (E10) Fabíola foi exonerada em 12 de fevereiro. (ATÉ MOSCAS..., 1987)

Durante a visita, Mann avaliou o programa brasileiro como "completo para 1987" e considerou que a campanha de prevenção proposta pelo Ministério da Saúde era "verdadeiramente histórica”, elogiando sua clareza e objetividade. (CAMPANHA..., 1987, p. 12)

Com a saída de Fabíola Nunes da Secretaria Nacional de Programas Especiais de Saúde (SNPES) no final de 1987, o Ministro Roberto Santos, seguindo a sugestão de Lair Guerra, criou a Divisão Nacional de DST/Aids (E10; E26) (OLIVEIRA, 2008), de forma que, sob a gestão de uma biomédica, o Programa saiu da DNDS, ganhando maior autonomia em relação à Dermatologia Sanitária, uma especialidade médica, e construindo, na visão de Pedro Chequer, um “modus operandi próprio.” (E27) s0 $^{50}$

Ainda que a separação tenha acontecido em 1987, foi oficializada apenas em 1988, através da criação da Divisão Nacional de DST/Aids, sob a direção de Lair Guerra, que permaneceu até março de 1990 (E15; ${ }^{51}$ E27), início de um novo governo. A Divisão foi transferida da Secretaria Nacional de Programas Especiais de Saúde (SNPES) para a Secretaria Nacional de Ações Básicas de Saúde (SNABS) e a sua criação era avaliada pelo Ministro Roberto Santos como uma valorização do Programa Nacional.

É interessante notar que, naquele período, a imprensa ainda tratava a aids de forma sensacionalista, alimentada pelo incipiente conhecimento acerca da doença pelo campo médico. Na mesma notícia o jornal Folha de São Paulo divulgava três assuntos relacionados à aids: uma fala do médico Ricardo Veronesi no congresso de infectologia que acontecia em Curitiba acerca de pesquisas realizadas na África que supunham a transmissão do

49 O Diretor do Programa de Aids da Organização Mundial de Saúde esteve no Brasil entre ze 4 de fevereiro de 1987, à convite do Ministro Roberto Santos, acompanhado de Ronald St. John, coordenador do Programa de Análise de Situação de Saúde e suas Tendências, da OPAS, e Fernando Zacharias, coordenador do Programa de Aids da América Latina, OPAS.

50 Entrevista concedida por E27, médico sanitarista, em Brasília, DF, em 3 de agosto de 2011.

51 Entrevista concedida por E15, secretária do Departamento de DST, Aids e Hepatites Virais do Ministério da Saúde, em Brasília, DF, em 4 de agosto de 2011. 
vírus HIV através de mosquitos; a exoneração de Fabíola Nunes e a criação da Divisão de DST/Aids; e por fim o posicionamento da Conferência Nacional de Bispos do Brasil (CNBB) acerca da campanha de prevenção do governo federal..$^{2}$ Contudo, a manchete concentrava-se no primeiro assunto. Essa ênfase no aspecto informado por um médico infectologista, professor da USP também aponta para a dominância e reconhecimento do saber médico como aquele que detém a autoridade sobre a doença.

Dadas as possibilidades terapêuticas do período e a insuficiência de recursos, a gestão de Lair Guerra pautou-se principalmente em iniciativas visando a estruturação do programa e a prevenção da aids. As atividades a serem implementadas no país passaram a ser normalizadas de forma centralizada, invertendo a sua relação com os estados que até então formulavam e executavam seus programas específicos. (TEIXEIRA, 1997) Além disso, a gestão de Lair Guerra foi marcada pela crítica das organizações não governamentais, em especial a Abia e o Gapa, principalmente no que tange à assistência aos doentes, às campanhas de mídia produzidas, e ao discurso do ministério, visto pelos grupos como normativo e medicalizador:

[...] Não há estímulo à pesquisa. Não existe um programa real de assistência ao doente. Não háleitos, médicos, medicamentos, hospitais. Não há um programa consistente de educação e informação. Frente a essa omissão, uma campanha foi montada agora, decidida em gabinetes e escritórios de agências de publicidade, oferecendo ao público uma cara da Aids e a fisionomia de um país desgovernado. Nesta campanha, a única informação realmente clara é a de que o Governo não conhece nem este país, nem as responsabilidades que tem diante dele. Só mesmo o mais completo desinteresse pela saúde pública pode justificar a sucessão de equívocos que modelou esta campanha. (QUEM SEMEIA..., 1988, p. 1)

As campanhas de televisão do Ministério da Saúde sobre Aids não informam a população, geram dúvidas sem darem a resposta imediata para esclarecê-las, e gastam muito dinheiro. [Paulo Bonfim, presidente do Gapa-SP] mais adiante neste capítulo. 
$[\ldots]$

Nós já atendemos diversas pessoas com dúvidas sobre o que ouviram e viram na TV. Temos que fazer uma verdadeira lavagem cerebral para ensiná--las corretamente. [Eduardo de Carvalho, presidente do Gapa-MG] (EM JUNHO..., 1988, p. A-20)

[...] O tipo de mensagem que jogamos é: a gente não é médico, não é nada, a gente é como vocês, pessoas que estão preocupadas com a aids, a gente foi aprender um pouco e está tentando transmitir o que aprendeu. Usem a sensibilidade, conheçam os fatos. O nosso lema é: estar informado éa melhor prevenção. Então, informem-se, leiam tudo, mas leiam com consciência crítica. A gente tem apelado muito para a sensibilidade das pessoas, para que elas próprias decidam o que é bom ou não é, para elas, e não deixem decidir os médicos, o presidente, o Ministério da Saúde, o que é, bom para a saúde dessas pessoas. O governo já decide tantas coisas da sua vida: o seu salário, a sua habitação. . . Agora vai decidir também a sua cama? Você é que tem que garantir o direito de decidir isto. [Arthur do Amaral Gurgel, presidente do Gapa-RJ] (O GAPA..., 1988, p. 10)

Em 1987, a primeira campanha governamental resultou do trabalho do grupo composto pelo publicitário Jorge Borges, a diretora da DNDS Maria Leide, o vice-diretor do Gapa-SP Paulo César Bonfim, e o general Aureliano Pinto de Moura, da Divisão da Saúde do Exército, e teve como slogan “Aids, você precisa saber evitar!”. (GOVERNO..., 1987, p. A-12) A campanha contava com cartazes (Figura 2) e chamadas de meio minuto na TV, abordando temas como uso de preservativo, camisa de vênus, nas relações sexuais, o risco de contaminação através do compartilhamento de seringas, ressaltando que a aids não se transmite na convivência diária com o doente e incentivando a doação de sangue. Ou seja, o foco da propaganda era na prevenção. Vale destacar que, até mesmo nas campanhas publicitárias, havia referência ao medo e à morte relacionados à aids. A seguir estão transcritos os textos de algumas dessas chamadas.53

Todos os vídeos analisados e transcritos estão disponíveis no sítio eletrônico do Departamento de DST, Aids e Hepatites Virais do Ministério da Saúde: <http://www.aids.gov.br/pagina/videos>. Acesso em: out. 2012. 
FIGURA 2 - Cartazes da campanha Aids, você precisa saber evitar
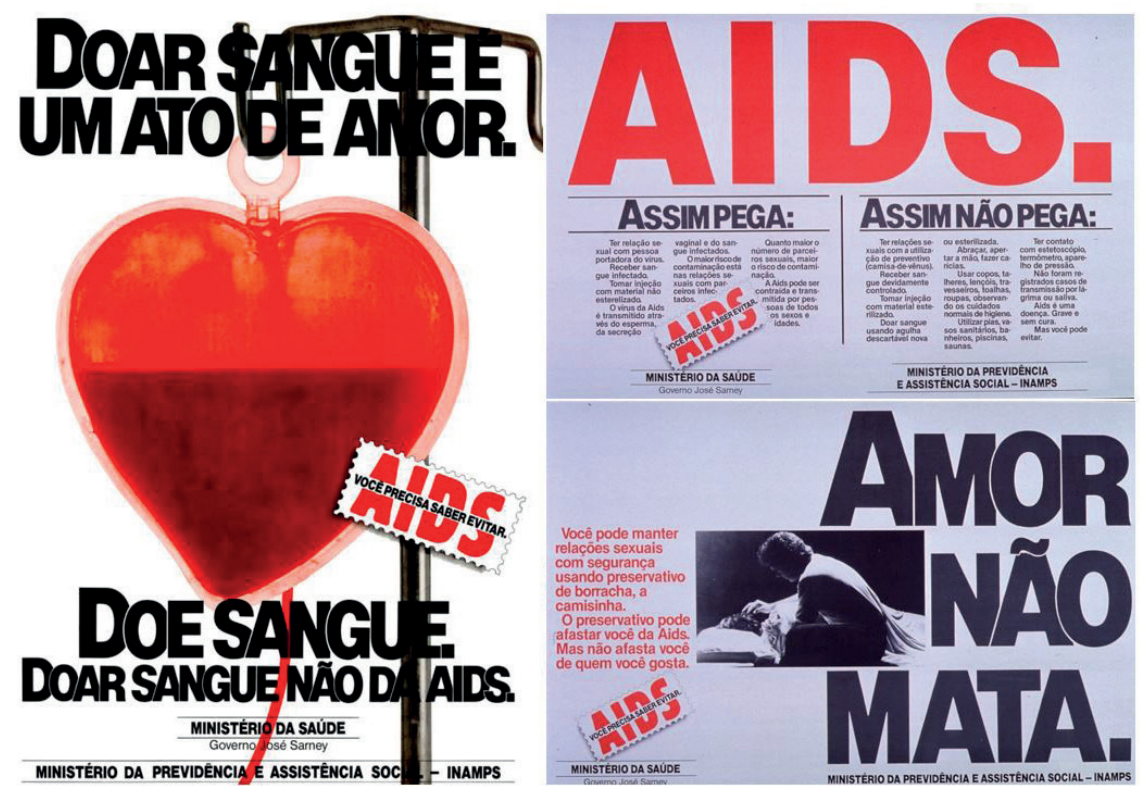

Fonte: Brasil (1987). 
A aids é uma doença que passa de pessoa para pessoa através do esperma e do sangue contaminado. A aids não tem cura e mata. Só tem uma maneira de evitar que esta epidemia continue: a prevenção. Nas suas relações sexuais use a camisa de vênus. A camisinha pode afastar você da aids, mas não afasta você de quem você gosta. (AIDS..., 1987c)

O vício da droga é uma agressão para a saúde e a agulha da seringa que passa de mão em mão pode estar contaminada com o vírus da aids. Se você não está conseguindo largar o vício, procure ajuda. Evite seringas usadas, assim pelo menos de aids você não morre. (AIDS..., 1987d)

De todos o sintomas da aids o que causa mais dor é a solidão. $\mathrm{Na}$ maioria dos casos a família e os amigos se afastam do doente da aids por medo e preconceito. Aids não se pega convivendo com o doente. Aids não se pega com abraço. Aids não se pega com afago e com afeto. Enquanto a cura não vem, carinho é o melhor tratamento. Aids você precisa saber evitar! (AIDS..., 1987a)

O medo da aids está assustando alguém muito importante para a saúde do país, o doador de sangue. Não tenha medo, não se pega aids doando sangue desde que a agulha seja descartável ou nova ou esterilizada. Doe seu sangue. Só assim você impede que a vida de muitas pessoas se esvazie nos hospitais. (AIDS..., 1987b)

Além dessas, havia peças publicitárias de um minuto com os atores Irene Ravache e Paulo José, esclarecendo sobre a forma de transmissão do vírus, sobre a doação de sangue e os riscos de contaminação através da transfusão de sangue e do compartilhamento de seringas.

A CNBB considerava que a campanha exaltava "práticas sexuais contrarias à natureza" e sugeriu a substituição dos termos "camisa de vênus" e "coito anal", por "preservativo" e "relação sexual" respectivamente. Na visão de Paulo Roberto Teixeira, da SES-SP, do médico infectologista Vicente Amato Neto, e de Paulo Cesar Bonfim, do Gapa, a aids era um problema sério e questões de ética e moral não poderiam impedir ações para evitar o crescimento da doença no país. A informação veiculada na mídia era de que haveria "censura prévia para evitar choques com a igreja". 
(PASTORAL..., 1987, p. A-16) De fato, esses foram os termos utilizados na campanha, como pode ser observado nos trechos citados anteriormente e aparentemente, o uso do termo "coito anal" referia-se ao primeiro filmete: Campanha Aids, você precisa saber evitar - dominó 1987, que, de acordo com a reportagem da Folha de São Paulo, inicialmente teria a imagem de nádegas nuas para reforçar a questão do sexo anal.

As críticas, contudo, surgiram principalmente em reação à campanha de 1988, que tinha o slogan: “Aids, pare com isso!”, para a qual foram elaborados dois vídeos com cerca de um minuto cada: no primeiro, uma aeromoça, antes da decolagem, explicava para os passageiros os meios de transmissão da aids e como se prevenir e usar a camisinha:

Senhores passageiros, bem vindos à bordo. Atenção para essas instruções que podem salvar sua vida nessa viagem: em suas relações sexuais, qualquer que seja o parceiro, use sempre camisa de vênus ou faça o seu parceiro usar; e se, por alguma razão, você tiver que tomar uma injeção, nunca use seringas e agulhas de outras pessoas, tenha certeza de que a seringa saiu diretamente de uma embalagem original, esterilizada e descartável; se precisar de uma transfusão de sangue, por qualquer motivo, exija o teste anti-aids no sangue que você vai receber. Lembre-se a aids mata sem piedade. Não deixe que essa seja a última viagem de sua vida. Aids, pare com isso! (AIDS..., 1988a)

A mensagem responsabilizava os indivíduos inclusive por medidas que fugiam a sua alçada, como o controle da qualidade do sangue. Ou seja, deslocava a responsabilidade do Estado para as pessoas.

No segundo, enquanto o texto era lido por um narrador, imagens da vida noturna de uma cidade eram alternadas, mostrando principalmente mulheres, e alertando aos perigos da noite, em especial a aids:

A noite tem alegria, tem diversão, tem amor, mas tem também muitos perigos. O maior deles chama-se aids. É uma doença que mata sem piedade. Ela é transmitida pelo sexo, pelas seringas e agulhas contaminadas e pelas transfusões clandestinas de sangue. Não dá para saber quem é e quem não é portador da doença. Quem vê cara, 
não vê aids. Use sempre camisa de vênus, qualquer que seja o seu parceiro sexual e se por alguma razão tiver que tomar uma injeção, nunca use seringas e agulhas de outras pessoas. Lembre-se de que a aids é uma doença mortal que está se alastrando cada vez mais. Depende de você, de todos nós, interromper esta triste ameaça. Não permita que esta seja a última viagem da sua vida. Aids, pare com isso! (AIDS..., 1988b)

No texto Onze críticas a uma campanha desgovernada (1988), a Abia classificava a campanha nacional de:

a. errada porque afirmava que deveria usar preservativo em todas as relações sexuais, o que a associação considerava que transformava o sexo em transmissor de culpa e medo;

b. hipócrita porque dizia que as pessoas deviam se cuidar para não receber sangue clandestino, quando essa era uma responsabilidade do governo;

c. irresponsável porque não estava vinculada a outras ações de saúde coletiva;

d. mentirosa porque falava em controle do sangue, mas não adotava as medidas contra os comerciantes de sangue;

e. falsa porque transmitia informações truncadas devido aos limites impostos pelas barreiras ideológicas e por disfarçar o descaso e a incompetência;

f. preconceituosa porque personalizava a doença em uma mulher, sendo machista;

g. alarmista porque apresentava informações parciais;

h. simplista porque apresentava uma uniformização simplificadora e só atingia um público anteriormente informado;

i. obscurantista porque era "elaborada através de sofisticadas fórmulas metafóricas";

j. elitista porque era dirigida a um público urbano e mais educado; e 
k. inútil porque a aids era um problema sério demais para ser tratada com filmetes e anúncios curtos.

Essa visão contudo tinha opositores. Por exemplo, na opinião de Luiz Mott, do GGB, a Abia privilegiava uma "perspectiva hemofílica” na abordagem das questões relacionadas à aids, em detrimento dos demais grupos.

[...] Rotular de 'errada' a campanha somente por que nalguns cartazes aconselhou o uso dos preservativos em 'todos' relações sexuais, é flagrante parcialidade do analista, pois em questão de vida ou morte, é melhor pecar pelo excesso do que pela falta de informações e cuidados. Dizer que o governo não está fazendo nada contra a Aids, é outra inverdade, pois por mais tardia, tímida e locunosa, a campanha governamental tem surtido palpáveis resultados na conscientização de amplas camadas sociais, sobretudo no tocante à profilaxia da Aids. Chamá-la de preconceituosa é uma injustiça, pois esse tem sido um dos aspectos mais positivos dessa campanha, que evita estigmatizar e mesmo citar os chamados 'grupos de risco', desmascarando preconceitos sociais contra os aidéticos. Apelidar a campanha de obscurantista por que usa fórmulas metafóricas sofisticadas, é outra mentira, pois malgrado a censura dos Bispos, as mensagens e imagens são bastante claras e compreensíveis por qualquer pessoa. Concluindo a avaliação feita pela Abia da Campanha do Governo contra a Aids peca pela intolerância, injustiça, falta de objetividade e derrotismo. [...] Rotular a Campanha de alarmista e estimuladora do pânico reflete grave desconhecimento por parte da Abia dos sentimentos e reações populares às informações prestadas pelo Governo, Convivendo semanalmente com centenas de homossexuais que frequentam a sede do Grupo Gay da Bahia, tenho elementos empíricos para confirmar que lastimavelmente a campanha não tem sido mais agressiva e dramática do que gostaria, pois boa parte dos gays baianos que frequentam o GGB continuam a fazer sexo na mesma frequência e risco como se a Aids não os ameaçasse, Entre os gays conscientes, há tranquilidade, entre os irresponsáveis. Indiferença. Onde está o pânico aludido pela Abia? A meu ver, falta maior contato dos teóricos do Abia com o povo brasileiro. [...] (MOTT, 1988, p. 12) 
Foram identificadas três concepções acerca das campanhas preventivas governamentais: uma concepção técnica, expressa principalmente pelos agentes do campo burocrático; uma concepção técnico-científica, que aparece na fala de agentes do campo científico; e uma concepção política, expressa principalmente pelos agentes do subespaço militante, mas também por agentes de outros subespaços com trajetória militante no movimento sanitário ou na luta pela redemocratização do país.

QUADRO 5-Síntese das concepções acerca da prevenção e das campanhas preventivas governamentais entre os agentes entrevistados

\begin{tabular}{|c|c|c|}
\hline SE & Concepções & \\
\hline \multirow{5}{*}{ 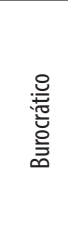 } & \multirow[t]{4}{*}{ Técnica } & Concepção asséptica do sexo \\
\hline & & Defesa do discurso sobre a gravidade da doença apoiado em argumentos médicos \\
\hline & & Defesa da campanha voltada para grupos de risco \\
\hline & & Oposição a uma visão limitada da prevenção \\
\hline & \multirow[t]{10}{*}{ Política } & Responsabilização da mulher na prevenção \\
\hline \multirow{8}{*}{ 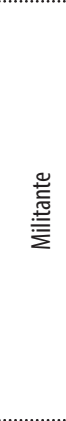 } & & As campanhas associavam a aids à morte, aos gays e a promiscuidade \\
\hline & & Oposição às campanhas específicas visando evitar a responsabilização dos gays \\
\hline & & Responsabilização dos gays, promiscuidade relacionada ao homossexualismo \\
\hline & & Falta de diálogo com a sociedade \\
\hline & & Prevenção restrita a campanhas, não articulada com assistência \\
\hline & & Crítica ao uso de termos científicos \\
\hline & & $\begin{array}{l}\text { Imposição de barreiras (pelo poder público e pela sociedade) para implementação de ações } \\
\text { inovadoras como a troca de seringas }\end{array}$ \\
\hline & & $\begin{array}{l}\text { Oposição de agentes do movimento homossexual à visão das lideranças soropositivas (disputa } \\
\text { interna) }\end{array}$ \\
\hline \multirow{2}{*}{ 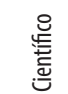 } & & Ausência de articulação com assistência \\
\hline & Técnico-científica & Defesa da campanha voltada para grupos de risco \\
\hline
\end{tabular}

Fonte: Elaborado pela autora.

Essas concepções acerca das campanhas governamentais evidenciavam as questões em jogo no espaço aids. (Quadro 5)

- A oposição às campanhas específicas voltadas para os denominados "grupos de risco," visando a não discriminação desses grupos foi um consenso inicial entre os representantes dos diferentes subespaços. Contudo, apesar de considerarem essa uma estratégia importante naquele momento, alguns entrevistados dos campos científico e 
burocrático a avaliaram negativamente, considerando que os estudos têm evidenciado, de fato, uma maior prevalência da infecção por HIV nesses grupos e a necessidade de um trabalho específico;

- A ausência de articulação com outras ações, seja assistenciais ou preventivas, limitando a prevenção às peças publicitárias e à distribuição de preservativos;

- A culpabilização dos homossexuais pela doença, evidenciada em um discurso que relaciona a promiscuidade à homossexualidade, como se não houvesse práticas sexuais perigosas para infecção por HIV entre heterossexuais, ou seja, as mulheres seriam vítimas, por exemplo, um entrevistado cita que falava-se em "suruba" entre homossexuais, mas não se falava de "swing" ou troca de casais entre heterossexuais;

- A incapacidade do Estado em fazer prevenção voltada para grupos específicos, transformando-a em uma atribuição do espaço militante (ONGs/Aids);

- A oposição à associação da doença à morte nas campanhas, especialmente por parte das ONGs/Aids e de soropositivos, que consideravam que estaria fomentando-se pânico e medo, bem como a discriminação, em contraposição aos que consideravam ser necessário um discurso claro e verdadeiro e que não associar a doença à morte seria escamotear a realidade;

- Existia por parte dos militantes também uma oposição ao uso de termos “científicos” pelo Ministério da Saúde, como preservativo em vez de camisa de vênus, considerada uma linguagem mais popular. Foi destacada também a dificuldade de implementação de estratégias devido a barreiras impostas pela própria sociedade, como aconteceu inicialmente com a tentativa de implementação de um programa de troca de seringas na cidade de Santos, São Paulo. Outro exemplo seria a interferência da igreja católica na censura prévia à campanha de 1987, como já relatado. 
Ou seja, havia um ponto de vista majoritário do movimento homossexual e das ONGs/aids, compartilhado também por técnicos progressistas que incorporava o cuidado contra o estigma e a discriminação, sem abrir mão da necessidade da mensagem técnica. Havia também um ponto de vista feminista, o ponto de vista médico asséptico e o ponto de vista médico-epidemiológico.

Nascimento (2005) considera que as campanhas governamentais sempre tiveram avanços e retrocessos desde o início da epidemia. Destaca a dificuldade em contemplar a diversidade de interesses envolvidos em um tema relacionado à sexualidade que suscita questões morais, políticas e religiosas, o que pode ser evidenciado em avaliações tão distintas provenientes de organizações do espaço militante: uma associação específica de luta contra a aids (Abia) e um grupo de homossexuais (GGB).

A necessidade de uma intervenção voltada para os grupos específicos, mais expostos ao risco de infecção pelo HIV e socialmente marginalizados, foi recomendação da Comissão Nacional de Aids na sua 5 a reunião (19 de janeiro de 1988). ${ }^{54}$ Prevaleceu entre seus membros a opinião de que a campanha deveria ser dirigida para a população geral, porém com ações para grupos específicos. Entre 1988 e 1989, o Programa Nacional elaborou o projeto "Previna - Prevenção e Informação sobre aids e outras DSTs". O projeto teve inicialmente como público-alvo profissionais do sexo, usuários de drogas e presidiários e, a partir de 1990, também garimpeiros da Amazônia legal, homossexuais e crianças e adolescentes em risco social. (CAMPOS, 2005)

O referido projeto não foi objeto de discussão específica na Comissão Nacional de Aids, mas a priorização dos grupos segue os temas das discussões e recomendações das reuniões seguintes da Cnaids, a saber: (BRASIL, 1994a)

a. Aids nos presídios, tema debatido na $4^{\mathrm{a}}$ reunião, realizada em 9 de outubro de 1987;

A ata da reunião do dia 19 de janeiro de 1988, diz que em votação a maioria optou por campanhas dirigidas à população geral, com ações para grupos específicos, porém não evidencia as discussões acerca do tema. 
b. Estratégia de trabalho com usuários de drogas, tema debatido na $6^{\mathrm{a}}$ reunião, realizada em 29 de fevereiro de 1988;

c. Aids e prostituição, tema da $8^{\text {a }}$ reunião, realizada em 2 de junho de 1988;

d. Crianças e adolescentes em situação de risco, tema da 11a reunião, realizada em 18 de abril de 1989; e

e. "Por consenso, a Comissão recomendou que a DN-DST/AIDS, desenvolvesse com maior ênfase projeto educativo dirigido a grupos de homossexuais", na $13^{\text {a }}$ reunião, realizada em 15 de agosto de 1989.

As estratégias do projeto Previna foram definidas a partir de uma série de reuniões com outros órgãos governamentais, universidades e organizações não governamentais e previam o treinamento de instrutores, produção de material informativo e distribuição de preservativo. O Previna foi implantado em seis estados: Rio Grande do Sul, São Paulo, Rio de Janeiro, Ceará, Bahia e Amazonas e no Distrito Federal, através de parcerias com ONGs. (CAMPOS, 2005)

Ela [Lair Guerra] criou o projeto Previna [...] que tinha como missão trabalhar em toda esfera nacional com 4 populações: população carcerária, populações de trabalhadores sexuais, população gay e usuária de drogas. E eu fui chamado por Dr ${ }^{a}$ Lair Guerra, logo depois de o Gapa-Bahia ter menos de 1 ano. [...] para ser o coordenador na região norte e nordeste do programa Previna nos presídios. Fiz um treinamento longo em São Paulo, no Carandiru, e depois eu era o responsável por toda a região norte e nordeste no Brasil. [...] para treinar todos os... Uma equipe de médicos, de profissionais paramédicos da população carcerária [...]. (E14) ${ }^{55}$

O Previna foi a primeira experiência mais formal de parceria entre o Estado e ONGs na prestação de serviços relacionados à aids. Os principais problemas para a sua implementação foram dificuldades no financiamento, em especial para a realização dos treinamentos e capacitações em abril de 2011. 
diversas regiões do país, e as divergências na linguagem a ser utilizada na elaboração do material didático, se seria uma linguagem mais técnica e científica, o que era defendido pelo Programa Nacional, ou uma linguagem mais próxima da cultura do público alvo, reivindicada pelas ONGs. (CAMPOS, 2005)

O repasse financeiro para estados e municípios foi realizado através da OPAS, tendo o Ministério como interveniente. O Previna foi descontinuado durante o governo Collor e retomado em 1992 no retorno de Lair Guerra ao Programa Nacional. (CAMPOS, 2005)

É importante ressaltar que se Lair Guerra não esteve desde o início da formação do programa, a sua chegada deu impulso a uma nova fase, contribuindo para a estruturação inicial do programa, a captação de recursos e o desenvolvimento de novas ações, voltadas, em especial, para a realização de campanhas de informação sobre a doença e a formação de uma comissão de experts, a Comissão Nacional de Assessoramento em Aids, atual Comissão Nacional de Aids (Cnaids).

Foi um período de construção da política nacional, baseada principalmente em ações de vigilância epidemiológica e medidas preventivas, no qual surgiu a primeira possibilidade de tratamento, a zidovudina (AZT), embora este medicamento apenas tenha sido disponibilizado na rede pública em 1989 por alguns Estados e em 1991 pelo Ministério da Saúde. A Comissão Nacional de Aids foi um importante espaço de definições técnicas e políticas a esse respeito, e, embora seu papel fosse consultivo, diversos documentos discutidos e propostos pela comissão formaram a base do discurso oficial. (PROGRAMA NACIONAL DE DST E AIDS, 2003)

Paralelo ao que acontecia no campo burocrático, a epidemia da aids mobilizou também agentes no campo científico.

\section{O isolamento do vírus no Brasil e as disputas do campo científico}

Em abril de 1985, a Fiocruz recebeu duas garrafas de cultura de HIV trazidas pelo casal Margueritte Pereira (Peggy) e Hélio Gelli Pereira. Ela, inglesa, diretora do Laboratório de Saúde Pública de Londres, ele, virologista 
brasileiro, naturalizado inglês, chefe de departamento de universidades inglesas. Foi esse material que permitiu o início dos trabalhos da adaptação da metodologia de diagnóstico sorológico já utilizado para Chagas e o desenvolvimento de kits diagnósticos para o HIV, criando a base para a triagem de bancos de sangue no país. O Brasil começou a realizar o diagnóstico através da técnica de imunofluorescência, visto que os bancos de sangue estavam equipados para realizar essa técnica utilizando como teste confirmatório o Elisa, distribuído pela OMS. (E4) (SANTOS; MORAES; COELHO, 1992) Como destacado por Pinell e colaboradores (2002), o início da realização de testes laboratoriais para diagnóstico da infecção pelo HIV, levou ao surgimento de uma nova categoria: a dos soropositivos, trazendo alterações para o quadro epidemiológico e na conformação do espaço aids, principalmente no espaço militante. No Brasil, contudo, até 2014, a vigilância epidemiológica trabalhava apenas com os casos confirmados de aids, contando apenas com estimativas para os soropositivos. (BRASIL, 2014a, 2014b) Se a figura do soropositivo não aparecia nas estatísticas, no espaço militante essas figuras começaram a ter um importante papel, em especial, no final da década de 1980.

Apenas em maio de 1987 o HIV foi isolado pela primeira vez no Brasil pela equipe coordenada pelo Dr. Galvão. ${ }^{56}$ (GALVÃO-CASTRO et al., 1987) Apesar desse não ter sido um fato científico importante - os países desenvolvidos já haviam isolado o vírus há cerca de 4 anos - , teve ampla divulgação pela imprensa, de modo que conferiu ao grupo de pesquisa um reconhecimento para além do campo científico e terminou por garantir novos financiamentos, funcionando como um importante capital simbólico. (GALVÃO-CASTRO et al., 1987; MOURA, 2005)

A equipe do Laboratório dirigido pelo Dr. Galvão era composta por Euclides Ayres de Castilho (epidemiologista), Jairo Ivo dos Santos (bioquímico), Claudio Ribeiro (imunohematologista), José Carlos Couto Fernandez (Biólogo), Vera Bongertz (bioquímica), Dumith Chequer Bou-Habib (Médico, Doutorando em Microbiologia da UFRJ, orientando de Bernardo Galvão) e Carlos Morel (Médico, Doutor em Biologia Celular, Diretor do Instituto Oswaldo Cruz). (GARCIA, 2011) A equipe era composta principalmente por jovens pesquisadores, recém-doutores, que voltavam ao país, outros como o próprio Galvão, com elevado capital científico nas áreas básicas, mas que ainda não tinham tanto prestígio. 
Como consequência, o Banco do Brasil solicitou um projeto para a construção de um Laboratório P $3 .{ }^{57}$ Avaliado inicialmente por um médico pneumologista como "não original", o projeto, no valor de 3 milhões de dólares, foi "engavetado" e só foi aprovado após intervenção do arcebispo do Rio de Janeiro, D. Eugênio Sales, junto a Camilo Calazans, então presidente do Banco do Brasil. Este projeto permitiu a construção do Laboratório Nacional de Saúde Pública em Salvador, o primeiro laboratório $\mathrm{P}_{3}$ da Fiocruz, não específico para aids, mas a partir do qual foi criada uma rede nacional de laboratórios para isolamento e caracterização do HIV no Brasil. (E4)

Com relação ao espaço aids no mundo, no subespaço científico, houve uma disputa pelo reconhecimento da autoridade científica pela identificação do vírus pelos grupos de pesquisadores do Instituto Pasteur, liderado pelo francês Luc Montagnier, e da Universidade da Califórnia, liderado pelo americano Robert Gallo. (CAMARGO JÚNIOR, 1994) No Brasil também observaram-se disputas pelo reconhecimento dos feitos científicos, ainda que esses, como já comentado, nem sempre recebiam grande importância científica internacional.

Essas disputas, algumas vezes, extrapolaram os limites do campo científico, e chegaram até as páginas dos jornais. Em 1988, por exemplo, a notícia da apresentação de um trabalho sobre detecção do vírus HIV-2

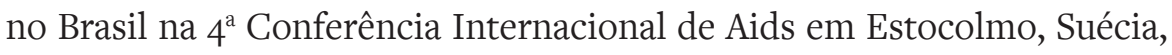
pelo médico da UFRJ, Eduardo Côrtes, que estava fazendo pós-graduação na Universidade da Califórnia (UCLA), EUA, gerou críticas do professor Ricardo Veronesi, que atribuía o mérito da descoberta a uma parceria entre a USP e a Universidade de Lisboa. (ALBUQUERQUE, 1988; VERONESI, 1988) 
Como se tratava de uma doença desconhecida, além dos médicos clínicos que atenderam aos primeiros casos, os pesquisadores das ciências básicas foram extremamente importantes na identificação do vírus, primeiro passo para o estabelecimento de medidas terapêuticas. Em sua maioria, eram jovens pesquisadores, em início de carreira, buscando se afirmar no campo científico, de modo que a aids surgiu como a possibilidade de independência científica de alguns recém-doutores, como Valéria Petri, ou pesquisadores em início de carreira, como Bernardo Galvão, por exemplo. Assim, as disputas geracionais, entre jovens pesquisadores e pesquisadores veteranos, bem como as disputas entre instituições, exemplificam as lutas desse subespaço: uma luta por reconhecimento dentro do campo científico do espaço aids, seja para alcançar ou manter uma posição de autoridade científica, ou mesmo uma posição de expert do Estado. (BOURDIEU, 2011)

Depois que o Ministério da Saúde me mandou um passaporte de serviço diplomático, sei lá o que é que era aquele passaporte lá, para eu ir representar o Brasil nos Estados Unidos, foi que começaram a me desdizer. É gozado. Aí o Dráuzio passou por mim 'Não liga não, que eles estão todos enciumados'. É assim para todo lado, não é? Ninguém consegue controlar essas coisas. Eu fui porque o Yunes indicou, ele me ligou, elefalou '[...] você vai representar o Brasil, porque eu indiquei você'. (E31)

Eles não aceitavam que não fosse a Fiocruz que fizesse, entendeu? E nós perdemos muita grana por causa disso. Eu consegui grants nos Estados Unidos. A UFRJ tinha um acordo firmado com a Fiocruz, tem até hoje, de colaboração: professor daqui vai prá lá, o de lá vem, pra cá. Se quiser. Funcionalmente. E o NIH ofereceu, convidei eles para fazerem juntos. O Ministério da Saúde não deu carta de que aprovava o trabalho. Não deu. E a gente ia fazer com eles. Convidamos formalmente eles para fazer. Mas como não foram eles que iam fazer, eles cancelaram. Dois milhões e meio de dólares. $(\mathrm{E} 7)^{58}$ 
Nessas evidências, verificam-se oposições tanto geracionais (Veronesi X Eduardo Côrtes, Veronesi X E31), bem como entre instituições (USP X UFRJ, USP X Escola Paulista de Medicina, UFRJ X Fiocruz).

Ao interior do campo médico, estava em jogo a relação de poder entre a recém-criada Infectologia, a Medicina Tropical e a Dermatologia. A Infectologia surgiu no Brasil em 1980, a partir da criação da Sociedade Brasileira de Infectologia, contrapondo-se à Medicina Tropical, com uma proposta de abranger as doenças infecciosas e parasitárias de forma diferenciada, incluindo todos os aspectos que envolviam as doenças infecciosas dentro da Medicina Interna e considerando que o termo Medicina Tropical não dava conta de uma epidemia como a aids, que não se restringia exclusivamente aos trópicos. (SBI..., 2005) Contudo, a Dermatologia, como identificou os primeiros casos, devido ao sarcoma de Kaposi, uma lesão de pele, e também pelo fato de abranger, àquela época, no Brasil, as DSTs, foi a especialidade da medicina que criou as bases para a elaboração da política de aids no país. Se nos EUA, os principais pesquisadores que se envolveram com a aids eram oncologistas, no Brasil, os oncologistas não tiveram um papel de destaque.

[...] Naquela época, eles achavam que uma dermatologista poderia atrapalhar a obra deles ou aquilo que eles pretendiam fazer. Então eles declaravam isso na televisão. Uma vez o Veronesi falou assim 'Dermatologista só serve para atrapalhar'. [...] Era muito mais difícil... Hoje não. Hojeénatural as pessoas aprenderem sobre isso, lidar com os medicamentos e tudo. (E31)

[...] como a aids começou com a epidemia de sarcoma de Kaposi, a oncologia nos Estados Unidos é que tomava conta da aids, da doença aids, compreendeu? E a Universidade da Califórnia era um dos maiores centro americanos de aids. O que a gente tinha de doentes, com sarcomas, linfomas, e era um centro de excelência, que fazia um monte de pesquisas, então, todos oncologistas. O Luc Montagnier [...] Ele era chefe da sessão de virologia tumoral do Instituto Pasteur. O Robert Gallo, o que era? Ele era do Instituto Nacional do Câncer Americano. (E7)

Os agentes dos campos burocrático, médico e científico sempre mantiveram uma relação importante com o espaço militante, inclusive alguns 
foram fundadores dos movimentos sociais envolvidos na epidemia e das associações específicas que surgiram com a conformação do espaço aids.

\section{O espaço militante}

Foi indiscutível a importância do movimento gay na elaboração das primeiras respostas à epidemia, sendo que alguns grupos, a exemplo do Grupo Gay da Bahia (GGB), até hoje realizam atividades relacionadas à prevenção da aids. A vinculação com os homossexuais, entretanto, reduzia a possibilidade de acesso a outros grupos devido ao preconceito por parte de determinados setores da sociedade. O próprio GGB, para dar continuidade às ações contra a epidemia da aids e ampliar a abrangência do público ao qual teria acesso, teve necessidade de criar uma organização específica, a qual compartilhava o mesmo espaço e membros que o GGB, mas que se desvinculava do movimento homossexual - Centro Baiano Anti-Aids (CBAA) ${ }^{59}$ Foi nesse sentido que surgiu a primeira associação específica de luta contra a aids, Gapa, em São Paulo.

\section{Grupo de Apoio e Prevenção à Aids - Gapa}

O movimento que levou à formação do Gapa teve início ainda em 1983. Em seu livro, Contrera (2000) afirma que as primeiras discussões surgiram em reuniões com o médico e professor Ricardo Veronesi, no Hospital das Clínicas da USP. Havia um descontentamento do público com o conteúdo das reuniões, consideradas exageradas, carregadas de preconceito e discriminação. (CONTRERA, 2000) A constituição do Gapa remonta à própria criação do Programa Estadual de Aids da SES-SP, haja vista ter

[...] em 87, fundamos o Centro Baiano Anti-AIDS, que eram as mesmas pessoas praticamente do GGB. Mas como para fazermos palestras, fazermos a situação de prevenção em ambientes oficiais ou particulares, em escolas, universidades, sindicatos, associação de bairro, a palavra Grupo Gay ainda provocava preconceito, então, nós achamos que era uma forma de diversificar e de camuflar a nossa atuação através do Centro Baiano Anti-AIDS e também a possibilidade de financiamentos nacionais e internacionais. (E2O) 
decorrido de reuniões promovidas por esse programa, ${ }^{60}$ realizadas nas instalações do Instituto de Saúde entre os anos de 1984-1985. (E3; E26)

As reuniões aconteciam às terças-feiras à noite e contavam com a participação de profissionais da SES-SP e pessoas da comunidade. O grupo Outra Coisa teve participação importante na divulgação dessas reuniões. As reuniões seguiam um roteiro acordado entre seus participantes: balanço da situação epidemiológica; atualização acerca do conhecimento sobre aids; ações promovidas pelo Estado para a prevenção, assistência e apoio às pessoas afetadas pela epidemia; esclarecimento de dúvidas; debate entre os participantes, moderado pela equipe do Programa, inclusive com críticas e sugestões ao trabalho desenvolvido pelo mesmo. ${ }^{61}$

Sempre chegavam novos participantes. Segundo o relato de E3, o ápice foi uma reunião realizada no Instituto de Saúde no início de 1985. Com objetivo de discutir a prevenção de riscos de infecção, foram apresentadas diversas imagens de lesões relacionadas à doença, o que causou muita comoção.

Eu ficava assim mais tranquila talvez, [...] porque eu não conhecia as pessoas que estavam ali, mas 90\% dos frequentadores da reunião conheciam os defuntos, as pessoas mortas. Na época, se passava muito vídeo, um pedaço da pessoa mostrando um sarcoma, um tumor. [...] Para mim era um pedaço, porque era um pedaço, mas tinha gente que reconhecia... 'Ai! Aliéa perna de meu amigo', [...] aparecia muito o rosto, mas tudo com sarcoma e via tudo já deformado. Mas os amigos reconheciam e então desmaiavam e gritavam. E a gente ficava assim... Eu, a Yara, a Otília não, porque a Otília trabalhava com isso, então, para ela era um outro olhar. Mas para mim e pra Yara... [...] Muito histerismo mesmo, eas reuniões, a bem da verdade, no

As reuniões começaram a acontecer alguns meses depois da criação do programa, e as reuniões públicas uma vez por semana, à noite, no nosso serviço. [...] eram muito concorridas, principalmente pela comunidade gay, mas também pessoas envolvidas no movimento de hemofílicos, no movimento de transfundidos, profissionais de Saúde Pública, pessoas de universidade. [...] e as pessoas que tomaram a iniciativa, no primeiro ano, praticamente, do Gapa, se reuniam no nosso espaço. Nós cedemos espaço, salas e facilidades de comunicação: correio, telefone etc., e foi o primeiro, digamos, apoio. [...] o Gapa nasceu dentro da instituição, na medida em que começou a se consolidar, e a se estruturar, foi procurar a sua sede própria, mas durante pelo menos um ano funcionou no nosso serviço. (E26)

61 Entrevista concedida por Paulo Roberto Teixeira, em São Paulo, em 5 de janeiro de 2016. 
início, elas mostravam esses vídeos... como é que você ficava, mas não tinha o que fazer. Então era só para dizer: 'Oh, você vai morrer assim'. (E3)

Essa afirmação também é reproduzida por Contrera (2000), tendo por base os depoimentos de dois fundadores do Gapa - Auréa Abbade e Claúdio Monteiro.

Um ponto de vista mais técnico é apresentado pelo então coordenador do Programa de Aids da SES-SP, E26, agente dos campos médico e burocrático:

É possivel que algumas pessoas que assistiam pela primeira vez aquela apresentação, como a própria Áurea Abade, reagissem com desconforto mas a imensa maioria já frequentava as reuniões fazia mais de um ano. [...] Houvesse ocorrido cenas tão dramáticas, certamente iriam para as páginas dos jornais, pois repórteres participavam regularmente dos eventos. [...]

A apresentação do quadro clínico incluía a projeção de slides demonstrativos das principais manifestações da doença. Após algumas reuniões, o Programa propôs suspender a projeção de slides, supondo que estas informações já estavam suficientemente difundidas. Os participantes rechaçaram a proposta, argumentando, entre outras razões, que novos frequentadores surgiam à cada semana.

As imagens eram cuidadosamente selecionadas de forma a evitar a identificação de seus portadores. Eventuais slides que mostravam o rosto de pacientes provinham de publicações, em geral internacionais. Guardo ainda hoje o material iconográfico utilizado, que está à disposição de quem tenha interesse em examina-lo. Os encontros se sucederam, sem interrupção, por todo o ano de l984 até meados de 1985 , quando os frequentadores mais assíduos decidiram se organizar em uma ONG e, assim nasceu o GAPA-SP.

Foi uma das experiências mais importantes de diálogo entre o estado e a comunidade já ocorrida na história da saúde pública brasileira, que requer ser registrada adequadamente.

Portanto são diferentes pontos de vista entre outros possíveis, que representam pelo menos dois grupos distintos, que não refletem todos os pontos de vista acerca desse evento específico, muito menos o conjunto da atuação do Programa Estadual de Aids da SES-SP. Mas ilustra a percepção 
de três agentes: uma advogada que estava indo pela primeira vez a uma reunião sobre o assunto, um sociólogo e um médico, todos com diferentes posições e tempos de inserção no espaço aids. Pontos de vista que não podem ser desconsiderados, mas que devem ser contrapostos aos demais pontos de vista possíveis, que não foi objetivo específico desse estudo, mas que uma investigação específica sobre a fundação do Gapa certamente daria conta.

Naquele dia, decidiu-se formar uma organização não governamental de base comunitária, com objetivo de, associada ao ativismo político, promover prevenção, informação e assistência a portadores de HIV/aids e seus familiares, ou seja, substituir o Estado em suas funções. (BARATA, 2006; CONTRERA, 2000) O Gapa foi assim criado em janeiro de 1985 e teve a sua ata de fundação registrada no dia 27 de abril de 1985. (CONTRERA, 2000) O Centro dos Hemofílicos de São Paulo, na pessoa de D. Vitalina Dias da Silva, teve papel importante no apoio à formalização do grupo, dividindo a experiência da sua instituição e orientando os primeiros passos a serem seguidos pelas duas advogadas do grupo, Áurea Abbade e Yara Aparecida de Arruda.

Como estava também atingindo os hemofílicos, ela fez parte no início com a gente. Os hemofílicos e os talassêmicos. Mas não com muita vinculação, porque eles tinham medo de se confundir ou de ter mais um estigma além do que já tinham. Não queriam ser os transmissores do HIV, então tinha uma participação mais de orientação. [...] Um modelo de contrato, modelo de não sei o que, modelo de ata... Isso foi durante a semana... Aísentamos... Primeiro que a gente já sabia como era o fundamento, quais eram as funções do Gapa, os objetivos, que isso já vinha sendo discutido há tempos. Aí nós fizemos uma adaptação disso para aqueles modelos que ela tinha nos dado. [...] (E3)

Entre os fundadores do Gapa havia profissionais da SES-SP, como Paulo Roberto Teixeira, Paulo Bonfim, ${ }^{62}$ Otília Simões Janeiro Gonçalves; ${ }^{63}$

62 Baiano, técnico em Patologia Clínica, militante do PT e candidato a deputado federal de 1990, participante no movimento da saúde através da Associação dos Funcionários do Hospital do Servidor Público Estadual - AFIAMSP e do Sindicato dos Funcionários da Saúde SINDSAÚDE, Coordenador do Programa Municipal de DST/Aids de São Paulo de 1989 a 1991, durante a gestão da prefeita Luiza Erundina. 
o antropólogo Edward MacRae; as advogadas Áurea Celeste da Silva Abbade e Yara Arruda; o publicitário e professor universitário Wagner Carmo Fernandes; o professor de História do Cinema da USP, Jean Claude Bernadet; o sociólogo Cláudio Monteiro; o jornalista Oilson Pedro Gomes; o economista Zilton Luis Macedo; o servidor público Luiz Carlos Munhoz; os artistas plásticos Jorge Schwartz, Mário Silvio Gomes e Hudnilson Urbano; e a ativista do movimento da saúde Neusa Cegali Cateasis. (CONTRERA, 2000)

Além da participação de agentes ligados à SES-SP e ao Programa Estadual de Aids, o Estado teve importante papel no financiamento do Gapa. Foi o Programa Estadual de Aids que garantiu estrutura para os primeiros meses da associação cuja sede provisória era no prédio da própria SES-SP. Ao mesmo tempo, o Gapa deu voz às críticas dos profissionais ligados ao programa, os representantes do Estado, os agentes do oficial, que muitas vezes não podiam denunciar publicamente os atos dos quais discordavam. (E3; E26) (CONTRERA, 2000)

O Gapa, que se constituiu com um perfil político-assistencial, foi fundamental na conquista de direitos dos portadores de HIV/aids, tendo participação ativa na Comissão Nacional de Aids desde seu início, bem como na formulação da legislação previdenciária para os portadores de HIV/ aids (ABBADE; BAIÃO, 2010; CONTRERA, 2000), tendo contribuído, através da advogada Áurea Abbade, para elaboração do texto que subsidiou a elaboração da Lei 7.670/88, que estende aos portadores de HIV/aids a concessão de licença para tratamento de saúde, aposentadoria, reforma militar, pensão especial, auxílio doença e pensão por morte aos seus dependentes. Paulo César Bonfim foi o idealizador da proposta e quem a levou para Lair Guerra em uma reunião. Lair encaminhou o pleito ao Instituto Nacional de Seguridade Social (INSS). (E3) Ou seja, a preocupação do Gapa era com os direitos, neste caso previdenciários, do portador de HIV/aids, e não apenas no âmbito da saúde, haja vista a proximidade estabelecida com os doentes e os ditos "grupos de risco". (FELTRIN, 1996; MARTINS, 1996) Além disso, foi a assessoria jurídica do Gapa que 
deu entrada nas primeiras ações contra o Estado para o fornecimento de medicamentos antirretrovirais. ${ }^{64}$

O Gapa sempre fazia corpo a corpo junto à comunidade gay e com outros grupos vulneráveis à aids em casas de show, boates, saunas e na Parada Gay. Chegou a ter uma casa de apoio, mas as dificuldades para manutenção da estrutura, mesmo com o apoio financeiro da SES-SP, num período de grande inflação, inviabilizou a continuidade da iniciativa. (CONTRERA, 2000)

O primeiro cartaz de prevenção à aids foi criado pelo $\mathrm{Gapa}^{65} \mathrm{e}$ foi duramente criticado pela igreja que considerava que ele disseminava ideias pecaminosas como sexo fora do casamento e masturbação. (CONTRERA, 2000; FATAL, 1988)

Era do movimento. A gente estava preocupado, queria alertar a população sobre a aids, ao mesmo tempo não queria levar uma mensagem repressiva. [...] alertar e lutar contra a repressão. E daí, eu vim aqui para Salvador e estava com Mott, que é um velho amigo meu, e lá no GGB ele tinha um cartaz americano. E esse cartaz americano dizia, eu não me lembro o que dizia exatamente, mas alguma coisa assim que 'você pode fazer tudo que sempre fez, mas tem que tomar cuidado'. Não sei se sugeria o uso da camisinha. Era um cartaz assim que tinha uma caricatura que era engraçadinha e que trazia uma mensagem não repressiva. Eu peguei esse cartaz e levei pra São Paulo e mostrei pra esse grupo de pessoas que estava se organizando. E daí a gente fez assim 'Vamos fazer um cartaz nosso'. E esse cartaz, surgiu. A mensagem principal foi eu que bolei. Era 'TRANSE NUMA BOA'. E daífoi o Darcy Penteado que elaborou o cartaz, que ele é artista plástico. O Jean Claude Bernadet, professor da USP, crítico de cinema. [...] e ele então, ele e o Darcy Penteado, depois, sentaram e bolaram mais ou menos o cartaz. Que era assim uma porção de palavrinhas. Boline, beije, acaricie, masturbe, não lembro, mas um monte de coisas que

64 A primeira liminar para fornecimento de antirretrovirais de última geração pelo Estado foi obtida por uma ação impetrada pela advogada Áurea Abbade, do Gapa, em nome da professora Nair Brito. (FELTRIN, 1996)

65 Outras iniciativas surgiram. No Rio de Janeiro, por exemplo, o Triângulo Rosa elaborou um informe sobre aids, que foi distribuído a todos que procuravam o grupo, sendo, portanto, sua circulação mais limitada. (FATAL, 1988) 
você poderia fazer. Assim, e em letras grandes 'TRANSE NUMA BOA'. Então esse foi o primeiro cartaz a ser feito no Brasil de prevenção a aids. (E8)

O cartaz estimulava o sexo seguro, ainda que esta não fosse a expressão usada àquela época. Trazia uma mensagem não repressiva, em oposição àquela que posteriormente foi adotada pelo Ministério da Saúde e destacava a possibilidade de manter o prazer mesmo frente à ameaça da aids.

O financiamento do Grupo veio de parcerias com a SES-SP, como já mencionado, a fundação Ford, e outras instituições, inclusive o Programa Nacional de Aids. (E3) (CONTRERA, 2000)

A partir da emergência do Gapa-SP, começaram a surgir outras associações específicas de luta contra a aids. Em 1986, surgem a Associação Brasileira Interdisciplinar de Aids (Abia), no Rio de Janeiro, e o Movimento de Apoio ao Paciente com aids (Mapa), em São Paulo, bem como foram fundados Gapas em diversas cidades/estados, como Minas Gerais, Rio de Janeiro, Paraná, Santa Catarina e Taubaté (1987); Baixada Santista, Bahia e Ribeirão Preto (1988); Rio Grande do Sul, Ceará, Itabuna e São José dos Campos (1989), Sergipe e Distrito Federal (1991). Vale destacar que os Gapas constituíram-se autônomos e independentes, mas compartilhando o nome e tendo um estatuto comum. ${ }^{66}$ (CONTRERA, 2000; GALVÃO, 2000)

\section{Associação Brasileira Interdisciplinar de Aids - Abia}

No Rio de Janeiro, em 1985, Herbert de Souza, o Betinho, sociólogo, militante contra a ditadura militar que havia retornado do exílio em 1979 com a anistia política, começou a reunir no Ibase um grupo de representantes dos movimentos sociais, médicos e pesquisadores para discutir a epidemia da aids. (PARKER; TERTO JUNIOR, 2001)

[...] essas reuniões se ampliaram em tamanho e passaram a atrair importantes líderes de movimentos sociais progressistas, como o advogado Nilo Batista, da Ordem dos Advogados do Brasil 
(OAB); o bispo D. Mauro Morelli; o antropólogo Rubem Cesar Fernandes, do Instituto de Estudos de Religião (Iser); médicos e cientistas como Walber Vieira, doutor em medicina e clínica geral, e Bernardo Galvão, da Fundação Oswaldo Cruz; representantes de entidades e grupos diversos como a Cruz Vermelha e o grupo gay Atobá; e o antropólogo Peter Fry, então representante da Fundação Ford no Brasil. (PARKER; TERTO JUNIOR, 2001, p. 15)

Álvaro Matida, médico epidemiologista do Programa de Aids da Secretaria de Saúde do Estado do Rio de Janeiro, que também participava das reuniões iniciais, apresentou Betinho ao médico Walter Almeida, que também passou a participar regularmente. Betinho e seus dois irmãos o cartunista Henfil, e o músico Chico Mário - eram hemofílicos. Henfil e Chico Mário já haviam se contaminado. Junto com Walter Almeida, Betinho resolveu criar uma organização não governamental, inspirado na International Interdisciplinary AIDS Foundation (IIAF). A psicóloga Silvia Ramos, que naquela época estava cursando o doutorado em Ciência Política no Instituto Universitário de Pesquisa do Rio de Janeiro (IUPERJ) ${ }^{67}$ ficou responsável pela formalização da instituição, através de um contrato de risco com Betinho, a mesma seria remunerada a partir do primeiro financiamento. A decisão formal de criação da Abia foi tomada no final de 1986, sendo seu estatuto registrado no dia 10 de abril de 1987. (PARKER; TERTO JUNIOR, 2001)

A Abia tinha por objetivo

promover o desenvolvimento de atividades sociais e científicas voltadas para a prevenção e o combate à Síndrome da Imunodeficiência Adquirida (AIDS), tais como estudos, pesquisas e projetos socioeconômicos, estudos sociopolíticos, formação de banco de dados, gerenciamento e interpretação de dados, preparo e divulgação de estudos e relatórios, boletins e publicações, por parte da própria organização ou através de terceiros e outras em Saúde Pública na ENSP/Fiocruz. 
atividades pertinentes a esse objetivo organizacional. (PARKER;

TERTO JUNIOR, 2001, p. 17)

Inicialmente, o Ibase fornecia a infra-estrutura necessária - telefone, fax, material de escritório etc. - ao trabalho da nova associação. O primeiro financiamento, de cerca de 5 mil dólares, foi conseguido junto ao Instituto Nacional de Assistência Médica da Previdência Social (Inamps), através de contato de Betinho com Hésio Cordeiro, médico sanitarista, militante da reforma sanitária e, à época, presidente do instituto. Para a obtenção do segundo financiamento, junto à Financiadora de Estudos e Projetos (Finep), ${ }^{68}$ estimado entre 100 a 200 mil dólares, foi fundamental o contato de Silvia Ramos com seu vizinho Reinaldo Guimarães, presidente da Finep e, assim como Hésio Cordeiro, militante da reforma sanitária. Ou seja, assim como aconteceu com o Gapa, foi a partir do financiamento estatal (Inamps e Finep) que a Abia obteve recursos para a sua estruturação inicial e em ambos os casos corroboraram a concretização desse financiamento agentes vinculados ao movimento sanitário. Mas foi com o financiamento assegurado pela Fundação Ford, da qual Peter Fry que fazia parte do conselho diretor da Abia, era representante no Brasil, que a associação conseguiu de fato se estruturar enquanto organização, tornando-se mais profissional, passando a remunerar alguns de seus membros por seu trabalho. (PARKER; TERTO JUNIOR, 2001; SOUZA, 2002)

Participavam do conselho consultivo da Abia Sérgio Luis Carrara, ${ }^{69}$ Peter Fry, Álvaro Matida, Peggy Pereira e Hélio Gelli Pereira. (PARKER; TERTO JUNIOR, 2001)

Como no Gapa, também havia agentes do campo burocrático que participavam da Abia, a exemplo de Álvaro Matida, também militante do movimento sanitário, mas esta se conformou principalmente com o objetivo de gerar informação, agregando um grande número de especialistas

A Finep é uma empresa pública vinculada ao Ministério da Ciência, Tecnologia e Inovação, criada 1967, que tem a missão de promover o desenvolvimento econômico e social do país por meio do fomento público à ciência, tecnologia e inovação em empresas, universidades, institutos tecnológicos e outras instituições públicas ou privadas.

69 Cientista Social pela Unicamp (1979-1982) e orientando de Peter Fry naquela época no mestrado de Antropologia Social da UFRJ. 
e com uma tentativa de distinguir o seu trabalho daquele desenvolvido pelo Gapa. A Abia seria mais política, enquanto o Gapa seria mais assistencialista. Silva (1999) descreve os grupos mais políticos como ativistas, enquanto os assistencialistas seriam aqueles que ofereciam serviços e atenção direta, assumindo o papel do Estado.

O Gapa tinha mais a perspectiva da advocacy, a Abia tinha uma concentração, uma expertise muito grande em dar informações e dar esclarecimentos para grupos especificos. (E29)

\section{[...] a parte da Abia era bem mais intelectualizada. (E31)}

Inicialmente, a Abia não tinha portadores do vírus na sua composição ${ }^{70}$ e sua relação com o movimento homossexual era menos evidente. Seus membros eram principalmente pesquisadores, médicos e profissionais de saúde. Era uma associação criada por um médico e um hemofílico, integrante de um dos grupos em risco, porém considerado como vítima da irresponsabilidade do Estado, ao contrário de homossexuais, profissionais do sexo e usuários de drogas injetáveis, que eram vistos como culpados pela sua contaminação. (PARKER; TERTO JUNIOR, 2001)

A Abia também teve importante papel na definição da política nacional de controle da epidemia, seja como representante na Cnaids, da qual se afastou em 1992 por divergências acerca do papel da comissão, seja com relação às campanhas educativas, sempre assumindo uma posição de oposição à subnotificação dos casos ou à insuficiência e descontinuidade da assistência. (AIDS..., 1988; ONZE..., 1988; PEDROSA, 1997; SOUZA, 1997) Para a Abia (PONTOS..., 1988, p. 7), "qualquer campanha de prevenção é uma CAMPANHA DE SOLIDARIEDADE” e deve ser baseada em um programa nacional de prevenção e controle da epidemia, elaborada com participação da sociedade civil, com a produção de "maratonas de informação, programas de horas, ${ }^{71}$ em horário nobre, onde se forneçam

O sociólogo Herbert de Souza, o Betinho, teve diagnóstico de aids depois da fundação da Abia.

71 Referindo-se a programas extensos de TV, em contraposição às chamadas publicitárias curtas, de cerca de meio minuto que compunham as campanhas governamentais. 
os dados necessários para que cada um entenda e decida" (PONTOS..., 1988, p. 7), fornecendo informações para que cada um pudesse entender e decidir, considerando as realidades locais e a diversidade da população brasileira, alertando e não alarmando a população como considerava que faziam as campanhas do programa nacional.

Herbert Daniel, que foi para a Abia convidado por Silvia Ramos em 1988, tornou-se rapidamente uma das principais vozes da instituição. Homossexual, com uma trajetória militante contra a ditadura e pelos direitos homossexuais, mesmo sem estar vinculado a grupos gays, foi exilado entre 1974 e 1981, sendo o último anistiado do país a regressar. Em 1989, descobriu-se soropositivo e fundou o Grupo Pela Valorização, Integração e Dignidade do Doente de Aids (Pela VIDDA), primeiro grupo criado por pessoas vivendo com HIV/aids no país e que assumiu um perfil político-assistencialista, mais próximo da forma de atuação do Gapa. (DIAS, 2012)

\section{Posições e disputas ao interior do espaço militante}

Com a entrada das associações específicas de luta contra a aids, houve mudanças no espaço militante. Se anteriormente esse espaço era dominado pelos grupos homossexuais, para os quais a aids era um tema transversal, um dos diversos problemas enfrentados pela comunidade gay, assim como para grupos de talassêmicos e hemofílicos, menos atuantes por não desejarem vinculação com mais um fator de estigma e discriminação. Os grupos específicos de luta contra a aids surgiram buscando se distanciar da causa homossexual e tendo como tema central o controle da epidemia da aids, a exemplo do Gapa e da Abia, passaram a assumir a posição dominante. Apesar do Gapa ser a primeira associação, a Abia rapidamente adquiriu um status dominante nesse subespaço devido ao corpo de experts que conseguiu agregar, o capital social de alguns membros do seu conselho consultivo e seu potencial para a captação de recursos, bem como a penetração de seus representantes nos meios de comunicação, em especial de Herbert de Souza e Herbert Daniel. Vale destacar que alguns agentes do espaço militante, como Betinho e Paulo Bonfim, assumindo a direção dessas instituições, conseguiram converter seu capital 
militante em capital político e exercer influência sobre os campos político e burocrático. São exemplos dessa influência o papel de Bonfim na legislação previdenciária aos portadores de HIV/aids e, principalmente, Betinho na legislação referente à questão do sangue e do acesso universal aos medicamentos para aids.

Da mesma forma, a entrada do grupo Pela Vidda, no início da década de 1990 no espaço militante, reforçou o discurso centrado no portador de HIV/aids, principalmente com a conformação de outros grupos com essa característica, como Grupo de Incentivo a Vida (GIV), em São Paulo, VHIVER, de Belo Horizonte (1993), a Rede Nacional de Pessoas Vivendo com HIV/aids (RNP+) (1994) e o movimento Patrocine a Vida, de Santos (1996). (CONTRERA, 2000; GALVÃO, 2000)

Considerando a proposta de Brown e colaboradores (2004) para a análise dos movimentos sociais em saúde, verifica-se que no subespaço militante do espaço aids existe a convivência das três categorias de movimentos:

a. Movimentos de saúde circunscritos a grupos específicos, representados pelos grupos de luta pelos direitos dos homossexuais, pelos grupos de profissionais do sexo e de mulheres;

b. Movimentos de saúde incorporados, no qual, além dos grupos de luta específica contra a aids, estão representados também os grupos de talassêmicos e hemofílicos, presentes principalmente nos anos iniciais da epidemia, quando o controle do sangue ainda era um problema; e

c. Movimentos de acesso a saúde, representados pelos agentes oriundos do movimento da reforma sanitária, que militavam também nas associações de luta contra a aids, não sendo a aids uma questão central para a reforma sanitária, mas bandeira de alguns agentes que tinham transito em associações específicas de luta contra a aids e também no movimento sanitário.

As disputas entre esses grupos ficaram bastante evidentes nos Encontros Nacionais de ONGs/Aids, os Enongs. A primeira reunião aconteceu em São Paulo, em 1987, reunindo os três Gapas existentes à época 
- São Paulo, Minas Gerais e Rio de Janeiro. Em 1990, no encontro de Porto Alegre, já contava com a participação de outras instituições, como GGB, Abia e Iser, quando foi proposta a criação de uma rede brasileira de solidariedade a ser discutida em um fórum ampliado em abril de 1990 na cidade de Santos. As disputas ao interior do espaço militante davam-se entre as associações de luta específica contra a aids e os grupos nos quais a aids apareceu como tema transversal - movimento homossexual, movimento de hemofílicos, renais crônicos e talassêmicos -, em especial os grupos homossexuais; e entre as associações específicas com posição mais política ou mais assistencial, com mais e menos recursos.

As principais disputas identificadas ao interior do espaço militante e na sua relação com os demais subespaços estão relacionadas a(o):

a. Financiamento, estrutura e articulação com o Programa Nacional de Aids, ONGs mais antigas, melhor estruturadas e com maior capacidade de captação de recursos eram denominadas "King-ongs" ou poderosas, enquanto as mais novas, eram consideradas pobres ou fracas; (E3) (CONTRERA, 2000)

b. Viver com HIV/aids - inclui-se apenas aqueles com HIV/aids ou se inclui infectados e não infectados que convivem com soropositivos; (GALVÃO, 2000)

c. Prevenção (Quadro 5), se o discurso incorporava ou não a discriminação e também uma mensagem condenatória aos homossexuais ou ao sexo; se pautada no medo ou na solidariedade, no viver com a doença; (E7; E2O)

d. Uso do termo técnico: homens que fazem sexo com homens (HSH), Apêndice C, para militantes homossexuais o termo é considerado uma "despolitização da homossexualidade", enquanto para outros militantes e profissionais da aids, o termo contribui para a inclusão de homens que têm práticas homoeróticas mas não se consideram homo ou bissexuais, bastante comum à realidade brasileira.

[...] afirmo que no Brasil (e talvez devido ao hipotético preconceito) a maioria dos homens que têm relação sexual com outros 
homens não se considera e não é considerada 'Homossexual'. Afirmo que o termo 'Homossexual' (ou seus sinônimos, todos pejorativos) é entendido (!) pela quase totalidade da população brasileira como referente a indivíduos que têm certos trejeitos afeminados e que são considerados marginais, sem vergonhas, ridículos, doentes, viciados, ligados à prostituição e ao crime [...]. (FATAL, 1988, p. 26)

Outro espaço onde eram tratadas as questões relacionadas à epidemia e que permite a identificação de disputas são as reuniões da Comissão Nacional de Aids.

\section{Comissão Nacional de Aids: a construção do discurso oficial}

Com a chegada de Maria Leide na DNDS em fevereiro de 1986, foi realizada uma reunião nacional do Programa Nacional de DST/Aids, sob a coordenação de Paulo Roberto Teixeira, do Programa Estadual de Aids de São Paulo, na qual foi traçado o primeiro plano de ação e foi criado um comitê assessor de aids, denominado "Comitê de grupos de risco". (OLIVEIRA, 2008)

O Comitêfoi histórico e coordenado por Paulo [Teixeira] inicialmente tendo grande ajuda de Jair Ferreira do Rio Grande do Sul, Lucia [Amaral], Eliana [de Paula] da SES-BA, Mirian, professores de DIP de várias universidades, Vicente Amato Neto, do Emílio Ribas, e os grupos de risco. [...] Uma das primeiras funções do comitê foi apoio na pressão por um orçamento que permitisse executar o plano traçado. (E24)

Com a chegada de Lair Guerra, a partir desse Comitê, foi criada a Comissão de Assessoramento em Aids, que se tornou responsável pela elaboração do discurso de autoridade com relação aos principais dilemas relacionados à epidemia da aids no país, quando ainda havia pouco conhecimento sobre a doença e não existia uma resposta terapêutica. A Comissão tinha caráter técnico-consultivo e como objetivos: assessorar o Ministério da Saúde em todos os aspectos relacionados ao controle da aids no Brasil; acompanhar a execução e participar da avaliação semestral do Programa de Controle da Aids; acompanhar no nível 
internacional a evolução das pesquisas relativas à aids; e assessorar a Divisão Nacional de Dermatologia Sanitária na divulgação das informações às Coordenações Estaduais do Programa. A portaria de criação da Comissão de Assessoramento em Aids indicava 18 representantes de diferentes órgãos e instituições, sendo sete membros natos: Conselho Federal de Medicina (CFM), Conselho Federal de Odontologia (CFO), Federação Brasileira de Hemofilia, Sociedade Brasileira de Hematologia e Hemoterapia, Colégio Brasileiro de Hematologia e Hemoterapia, Inamps, Grupo de Apoio e Prevenção à Aids; e representantes de 11 instituições que compunham a secretaria executiva: a diretora da DNDS, o diretor do Centro Nacional de Referência em Aids, os diretores dos Centros Nacionais de Referência das DST, e representantes do Prósangue, do Programa Nacional de Capacitação de Pessoal para Controle da Infecção Hospitalar, da Secretaria Nacional de Vigilância Sanitária, do grupo de Odontologia do Ministério da Saúde, da Divisão Nacional de Educação em Saúde, da Fiocruz, da Divisão Nacional de Epidemiologia e da Coordenadoria de Comunicação Social do Ministério da Saúde. Além de "sete personalidades de notório saber e reconhecida atuação no controle da aids, indicados pelo Ministério da Saúde" (BRASIL, 1986c), contudo não houve uma relação nominal de quem eram esses representantes e nem foram localizadas as atas das duas reuniões realizadas nesse período. (BRASIL, 1994a; PROGRAMA NACIONAL DE DST E AIDS, 2003)

A partir de 1987, a sua denominação foi modificada para Comissão Nacional de Controle da Síndrome da Imunodeficiência Adquirida (CNCSIDA) e a lista de membros passou a ser nominal, indicando a instituição de cada participante. Os 10 membros da comissão foram indicados pela equipe do Programa Nacional de DST/Aids, compondo um grupo de experts, todos médicos, à exceção de Lair Guerra, biomédica, e de Hélio Pereira Dias, assessor jurídico do Ministério da Saúde. (Quadro 6) Assim, houve um retrocesso no número de componentes e a exclusão do Gapa (BRASIL, 1987), o que indica um reforço do componente técnico-científico. 
QUADRO 6 - Membros da CNCSIDA, conforme portaria MS/GM n. 101 de 10 de março de 1987, e trajetórias profissionais

\begin{tabular}{|c|c|}
\hline Membro (Instituição) & Trajetória profissional \\
\hline $\begin{array}{l}\text { Lair Guerra de Macedo Rodrigues } \\
\text { (DN DST/Aids) }\end{array}$ & $\begin{array}{l}\text { Biomédica, especialista em Administração de Saúde Pública e DST pelos CDC (EUA), } \\
\text { mestrado e doutorado por universidades americanas na área de DST, professora da UFPB } \\
\text { e mais tarde da UnB, trabalhou na área técnica de Saúde da Mulher do MS, Coordenadora } \\
\text { da Divisão Nacional de DST/Aids. }\end{array}$ \\
\hline Antônio Carlos Gerbase (SES-RS) & $\begin{array}{l}\text { Graduado em medicina UFRGS (1974), na década de } 1980 \text { estava na Unidade de } \\
\text { Dermatologia Sanitária da SES-RS como supervisor do programa de doenças venéreas e } \\
\text { por volta de } 1996 \text { foi para a OMS. }\end{array}$ \\
\hline Antônio Paulo de Menezes Filho (Inamps) & $\begin{array}{l}\text { Médico, em } 1988 \text { era Vice-diretor de pesquisa e ensino do Hospital Evandro Chagas e } \\
\text { Assessor da presidência do Inamps. }\end{array}$ \\
\hline Euclides Ayres Castilho (Fiocruz) & $\begin{array}{l}\text { Médico com Residência e doutorado em Medicina Preventiva (USP), livre-docente (1976) } \\
\text { pela USP, docente do Departamento de Medicina Preventiva da USP (1968-1985) e } \\
\text { epidemiologista da Fiocruz (1985-1996). Entre } 1996 \text { e 2000, foi Coordenador substituto } \\
\text { da Coordenação Nacional de DST/Aids. }\end{array}$ \\
\hline Hélio Gelli Pereira (Fiocruz) & $\begin{array}{l}\text { Virologista brasileiro, com carreira na Inglaterra onde foi Chefe da Divisão de Virologia } \\
\text { do Instituto Nacional de Pesquisas Médicas e chefe de Departamento de Virologia em } \\
\text { universidade, após a aposentadoria na Inglaterra voltou ao Brasil, para a Fiocruz. }\end{array}$ \\
\hline Hélio Pereira Dias (Ministério da Saúde) & $\begin{array}{l}\text { Advogado, assistente jurídico do Ministério da saúde e assessor do ministro da saúde, } \\
\text { palestrante na da } 8 \text { a (NS ("Saúde como direito de todos e dever do estado") }\end{array}$ \\
\hline $\begin{array}{l}\text { Norton de Figueiredo (Ministério da } \\
\text { Educação)* }\end{array}$ & Professor de Clínica de Doenças Infecciosas e Parasitárias da UFRJ \\
\hline Paulo Roberto Teixeira (SES-SP) & Médico dermatologista sanitário, gestor do Programa Estadual de aids de SP \\
\hline Vicente Amato Neto (USP) & Professor de Doenças Infecciosas e parasitárias da USP \\
\hline Walter Belda (USP) & Professor da cadeira de Dermatologia Sanitária da Faculdade de Saúde Pública da USP \\
\hline
\end{tabular}

Fonte: Elaborado pela autora.

Nota: * Norton de Figueiredo era coordenador do programa de aids da UFRJ e não chegou a participar de reuniões da Comissão Nacional. Celso Ferreira Ramos, que trabalhava com ele na UFRJ, como coordenadorexecutivo do programa de aids o substituiu desde a primeira reunião. (PROGRAMA NACIONAL DE DSTEAIDS, 2003)

Entre 1986 e 2001, foram publicadas oito portarias que alteraram a composição e denominação da Comissão, mas mantiveram seus objetivos, adequando-os à estrutura do Ministério da Saúde em cada momento. Em 1994, sofreu uma reformulação e recebeu a denominação pela qual é conhecida até hoje: Comissão Nacional de Aids (Cnaids). (BRASIL, 1986c, 1987, 1988c, 1992, 1994a, 1994b, 1996b, 2000a; PROGRAMA NACIONAL DE DST E AIDS, 2003)

Em 1988, voltaram a figurar na sua composição representantes da sociedade civil organizada, incluindo além do Gapa-SP, outras associações interessadas na epidemia da aids como GGB, Abia, Sociedade Brasileira para o Progresso da Ciência (SBPC), Conselho Nacional de Igrejas Cristãs 
(Conic) e Associação Nacional de Moradores; representantes das universidades; do ministério da saúde; das secretarias estaduais de saúde e do campo médico. (BRASIL, 1988c)

Enquanto instância de assessoramento ao Programa Nacional nas questões técnico-operacionais relacionadas à epidemia da aids, a Cnaids assumiu importante papel na formulação inicial da política, constituindo-se como um grupo de experts no assunto, de diferentes subespaços sociais, que construíam o discurso oficial. (PROGRAMA NACIONAL DE DST E AIDS, 2003) A redação das normas/relatórios era delegada ao médico infectologista Vicente Amato Neto, professor de Doenças Infecciosas Parasitárias da Faculdade de Medicina da USP, apontando mais uma vez para a posição dominante dos médicos nos diferentes subespaços do espaço aids. (E27) No período de 1986, quando foi criada, até 2001, foram realizadas 63 reuniões da Cnaids. (BRASIL, 1994a; PROGRAMA NACIONAL DE DST E AIDS, 2003)

Na primeira gestão de Lair Guerra (1986 a 1989), a discussão dos pontos de pauta resultavam na elaboração de recomendações técnicas que eram adotadas pelo programa ${ }^{72}$ ou na constituição de subcomissões de especialistas para a definição de normas, tendo como base essas recomendações que incluíam membros e não membros da comissão, como no caso da definição dos critérios para uso do AZT. (BOLETIM..., 1988a; BRASIL, 1994a)

A introdução de um dos números do boletim epidemiológico, que traz um documento elaborado pela Comissão Nacional de Controle e Prevenção da Sida/Aids, deixa claro o seu papel na elaboração do discurso oficial:

Os documentos publicados nesse número representam a posição da DIVISÃO NACIONAL DE DST/AIDS-MS sobre direitos humanos e sobre a questão de testes sorológicos para a entrada no País. Qualquer pronunciamento contrário a esta posição é de responsabilidade pessoal do declarante. (RODRIGUES, 1989, p.1)

Por exemplo os documentos "Recomendações sobre o uso de AZT no país" (1994a), posicionamento inicial acerca da "Aplicação de teste anti-HIV para estrangeiros" (1988) e o documento "Crianças e adolescentes em situação de risco" (1989), os dois últimos publicados inclusive no Boletim Epidemiológico Aids. 
Ou seja, naquele período, a Comissão era parte do Estado e teve importante papel técnico e político, assessorando o Programa na definição das estratégias a serem adotadas. (BRASIL, 1994a) Contudo, em outras instâncias governamentais isso nem sempre ocorria, a exemplo da obrigatoriedade da testagem para admissão e nos exames periódicos das forças armadas, que iam contra a orientação ético-legal da comissão. Essa orientação foi revogada em 2001 através de ação civil pública (Portaria n. 12/DGS, de 25 de janeiro de 1989). (PROGRAMA NACIONAL DE DST E AIDS, 2003) De modo que a referida comissão era reconhecida principalmente dentro do espaço aids, o que implicava poder simbólico, mas não fora desse subespaço social.

Para Bourdieu (2012, p. 49, tradução nossa),

A comissão é uma invenção organizacional [...] que consiste em juntar as pessoas de tal maneira que estando organizadas desta forma farão coisas que não fariam se não estivessem assim organizadas..$^{73}$

A comissão produz efeitos simbólicos da entrada em cena do oficial, dá conformidade oficial à representação oficial, elabora uma (nova) definição de um problema público, elabora uma solução, um relatório, que se torna discurso de autoridade. (BOURDIEU, 2012) O meta-poder do Estado materizalizava-se nas resoluções da Cnaids, incorporadas como políticas. Do seu surgimento até o final da primeira gestão de Lair Guerra em março de 1990, foi esse essencialmente o papel da comissão.

Entre os membros da Cnaids havia representação do Conselho Nacional de Igrejas Cristãs (Conic), mas outras instituições das diferentes tradições religiosas também tiveram participação ou influência no espaço aids. semble de telle manière qu'étant organisés de cette façon, ils font des choses qu'ils ne feraient pas s'ils n'étaient pas organisés comme ça." (BOURDIEU, 2012, p. 49) 


\section{O campo religioso e o controle da aids}

Alguns estudos têm analisado a resposta religiosa à epidemia da aids no país, abordando a contribuição das diferentes tradições religiosas. (GALVÃO, 1997; GARCIA et al., 2009; GARCIA; PARKER, 2011; MURRAY et al., 2011) Esse estudo não teve como objetivo abordar os aspectos envolvidos nessa questão, entretanto, tratando-se de uma sociedade na qual a religiosidade e o ecumenismo são bastante presentes e de uma enfermidade relacionada à sexualidade, ao uso de drogas e, do ponto de vista religioso, à transgressão moral, a questão religiosa algumas vezes emergiu nas falas dos entrevistados, denotando a importância de analisar o papel dos agentes desse campo na configuração da política brasileira para controle da epidemia da aids no país, em especial para as estratégias de prevenção.

A análise apresentada nesse tópico foi embasada em alguns fatos históricos identificados nas entrevistas e em análise documental, bem como, revisão bibliográfica sobre o tema resposta religiosa, buscando elucidar a sua interferência na elaboração do discurso oficial.

No Brasil, até a década de 1970, havia uma hegemonia da religião católica entre os brasileiros, que superava o percentual de 90\%, resultado da influência do processo histórico de colonização portuguesa e do status de religião oficial até $1891 .{ }^{74}$ Atualmente, a religião católica continua sendo predominante no país (73,6\% em 2000; 64,6\% em 2010), a despeito da tendência ao crescimento da diversidade de outros grupos religiosos, em especial de evangélicos, que passaram de $15,4 \%$ em 2000 para $22,2 \%$ em 2010. (IBGE, 2012)

No início da epidemia, a inexistência de uma terapêutica eficaz e as características de uma doença fatal tornavam a capacidade de resposta religiosa no nível local, por vezes, maior que a do próprio sistema de saúde, apesar de a doença historicamente ter sido associada ao pecado no discurso religioso.

De acordo com a Constituição Federal de 1891, seção II, artigo 72, §70: “Nenhum culto ou igreja gozará de subvenção oficial, nem terá relações de dependência ou aliança com o Governo da União ou dos Estados." 
Inicialmente, o discurso, em especial da igreja católica, mas também das igrejas pentecostais, relacionava-se à decadência moral, associando a aids a desvios de comportamento, haja vista os principais grupos atingidos pela epidemia - homossexuais, usuários de drogas injetáveis e profissionais do sexo. Esse ponto de vista reforçava o estigma e a discriminação associados aos grupos de risco. A aids era denominada por Dom Eugênio Salles, arcebispo do Rio de Janeiro, como um “castigo divino", como o preço a pagar pelas transgressões cometidas. (GALVÃO, 1997; PARKER, 2009)

Vale lembrar, contudo, que D. Eugênio Salles teve importante papel na viabilização da construção do primeiro laboratório $\mathrm{P}_{3}$ no Brasil, intervindo junto a Camilo Calazans, presidente do Banco do Brasil, para a reconsideração da proposta inicialmente rejeitada pelo responsável pela avaliação do projeto, que possibilitou a criação da rede nacional de laboratórios para isolamento e caracterização do vírus no país.

A CNBB também influenciou as mensagens e a linguagem utilizadas nas campanhas governamentais, como já comentando anteriormente.

Haja vista a proximidade com as populações menos favorecidas e a valorização da caridade e da solidariedade no discurso e na prática religiosos, a principal característica da resposta à epidemia da aids nas diferentes tradições religiosas foi o papel desempenhado na assistência e prevenção, sobretudo voltada para crianças e mulheres, expressas na implantação de casas de apoio e na assistência domiciliar, sendo exemplos a Casa Vida, da Arquidiocese de São Paulo, a Praids, ${ }^{75}$ de orientação protestante, o Centro de Convivência Filhos de Oxum, ligada ao candomblé, ou o grupo ecumênico Associação de Ação Solidária (ASAS), no Recife. (GALVÃO, 1997)

Para as religiões afro-brasileiras, consideradas como mais tolerantes às questões relacionadas à sexualidade, ${ }^{76}$ a aids implicou também na necessidade de novas práticas relacionadas aos rituais, como o uso de

75 A Praids é uma casa para atendimento de doentes com HIV/aids, mantida pela Visão Mundial em convênio com o Centro Evangélico de Apoio à Vida, Ceavi, na zona sul de São Paulo. sileira em geral a rejeição a esse grupo chegava a até 80\%. (MOTT, 1998) 
descartáveis ou a esterilização de instrumentais perfurocortantes utilizados como navalhas, tesouras, lâminas de barbear e outros, e condutas em situações envolvendo soropositividade dos filhos de santo do terreiro, além da formação de multiplicadores. (EPEGA, 1998; GALVÃO, 1997; SILVA, 1998) Muitas ações foram iniciativas de grupos não religiosos como Instituto de Estudos da Religião (Iser), Centro de Referência e Treinamento DST/Aids - São Paulo (CRT-SP) e Grupo Gay da Bahia (GGB). (GALVÃO, 1997)

Assim como nos campos médico, burocrático e no espaço militante, São Paulo também foi pioneiro na resposta religiosa. Em 1987, a Arquidiocese de São Paulo, através do seu arcebispo D. Paulo Evaristo Arns, implantou o Projeto Esperança, que promovia atendimento jurídico, apoio religioso e distribuição de cestas básicas. D. Paulo teve como braço direito nesse Projeto o padre Aníbal Gil Lopes, ${ }^{77}$ também médico e pesquisador, ou seja, a configuração da primeira iniciativa no campo religioso, então, teve como um dos seus principais agentes um padre médico. (GALVÃO, 1997) Ainda que essa não tenha sido uma situação frequente, evidencia mais uma vez a dominância do campo médico no espaço aids.

No campo burocrático, o CRT-SP também incentivou a resposta religiosa, através da criação, em 1988, do Grupo Religioso de Educação, Apoio e Solidariedade, de caráter ecumênico, que buscava definir áreas de atuação e capacitar integrantes das diferentes religiões; e no dia $1^{\circ}$ de dezembro de 1988, dia mundial de combate à aids, 20 líderes religiosos participaram de ato ecumênico na Catedral da Sé, também a partir de uma mobilização promovida pela SES-SP. (GALVÃO, 1997)

O principal conflito entre o discurso do campo burocrático e o campo religioso sempre esteve relacionado ao uso do preservativo, em especial para as religiões de tradição cristã, na qual predominam os conceitos

Filho de uma família de pesquisadores, Aníbal graduou-se médico pela USP em 1973. Ainda durante a graduação resolveu cursar em paralelo o curso de Teologia do Seminário Arquidiocesano de São Paulo. Foi ordenado padre em 1973 com autorização do Papa Paulo VI por não ter cumprido as exigências mínimas para o ingresso oficial na igreja em função da formação em paralelo com o curso de medicina. À época, já era doutor em Fisiologia de Órgãos e Sistemas pela USP (1976) e tinha feito pós-doutorado na área de Biofísica de Processos e Sistemas na Universidade de Yale (EUA). (GAMBOA, 2005) 
relacionados ao campo da moral. Para a igreja, as campanhas que incentivavam o uso do preservativo para prevenção da aids eram um estímulo à promiscuidade sexual. (GALVÃO, 1997; PARKER, 2009)

Estudos têm evidenciado uma divergência entre o discurso oficial da igreja católica, proferido pelas principais autoridades eclesiásticas, condenando ou silenciando as campanhas preventivas que promoviam o uso do preservativo e o respeito às diversidades sexuais e a atuação de alguns de seus agentes, principalmente no nível local. Neste último nível, as lideranças eclesiásticas locais adotavam posições mais flexíveis, semelhante àquela da instituição com a qual a diocese conseguia articular a resposta à epidemia. (MURRAY et al., 2011; PARKER, 2009)

As religiões afro-brasileiras mostravam-se mais receptivas quando se tratava de uso de preservativos. De acordo com o levantamento junto a terreiros de Salvador, realizado pelo Centro Baiano Anti-Aids, os pais e mães de santo entrevistados reconheciam o preservativo (47\%) e a informação (15\%) como melhores formas de proteção, seguidos da prática de sexo seguro, utilização de material perfuro-cortante descartável e esterilizado, ainda que também tenham referido o afastamento dos portadores e a prática da monogamia, em proporções menores; além de em sua maioria (93\%) terem concordado em se tornar centros de prevenção da aids e distribuição de preservativos. (MOTT, 1998)

O fato de Lair Guerra, primeira coordenadora do Programa Nacional de DST/Aids ser batista, pode ter contribuído no enfrentamento ao posicionamento da igreja católica, mantendo a autonomia do Programa e do Estado na elaboração do discurso oficial.

[...] a igreja queria interferir, mas eu acho que foi um momento favorável porque a Lair era batista e a interferência da igreja católica era vista como uma coisa esquisita, protestante e a igreja católica romana. [...] qualquer voz de interferência católica, era mais que a interferência do estado lá, era uma ofensa do ponto de vista da ideologia religiosa. [...] Então isso ajudou sabe, ajudou por que talvez se fosse ao contrário fosse mais aquiescente, né? Já imaginou se fossem os católicos carolas, por exemplo, ia ser muito mais aquiescente à intervenção da igreja católica. [...] (E27) 
Contudo, percebe-se que nem sempre o discurso oficial ficou livre da interferência do campo religioso, em especial da igreja católica, predominante no país, o que pode ser ilustrado pela “censura prévia” imposta à campanha de 1987 pelo Ministro da Saúde que resultou na substituição de termos como "camisa de vênus"e "coito anal", pelos termos "preservativo” e "relação sexual”, por sugestão da CNBB. (PASTORAL..., 1987)

Essa articulação entre agentes de diferentes subespaços foi uma marca da resposta brasileira à epidemia da aids. A complexidade e diversidade das relações estabelecidas, congregando militantes, médicos, religiosos, pesquisadores e burocratas, contribuíram para a complementaridade das diferentes visões, resultando em uma resposta estatal precoce, baseada nos princípios propostos pela Reforma Sanitária Brasileira, embora incipiente e pouco estruturada, principalmente em decorrência das possibilidades terapêuticas da época e da estrutura do Sistema Único de Saúde que começava a ser implantado. A criação de novas instituições especializadas naquele primeiro momento, como associações de luta contra a aids, estruturas administrativas especializadas - programas estaduais, programa nacional -, centros de aconselhamento e testagem e centros de referência, bem como o estabelecimento de grupos de experts, em suas respectivas áreas, foram fundamentais para a consolidação da política nacional no período seguinte (1990-2001), com a adoção de medidas de vanguarda para um país em desenvolvimento. 



\section{4 \\ Evolução e consolidação \\ da política nacional de luta contra a aids (1990-2001)}

A resposta à epidemia da aids, na década de 1980, ocorreu a partir da integração e complementaridade da ação de agentes de diferentes subespaços. Sendo os homossexuais o principal grupo afetado àquele momento pela aids, o movimento gay teve importante papel na divulgação de informações acerca da doença e sua prevenção, assim como demandou uma resposta governamental. A ocorrência de casos concentrava-se na maior cidade e principal centro econômico do país, a cidade de São Paulo, onde também surgiu, no final da década de 1970, o primeiro grupo homossexual do Brasil: o grupo Somos, a partir do qual o referido movimento se organizou no país. Apesar de em um primeiro momento o movimento gay ter negado a doença, teve papel fundamental no reconhecimento da aids como um problema social que necessitava de medidas específicas.

A resposta governamental à aids, no Brasil, apresentou uma especificidade, relacionada ao nível de governo que implantou as primeiras ações. Tradicionalmente o Ministério da Saúde formulava uma política nacional que era seguida e operacionalizada pelas unidades federativas. Em relação à aids, diversas ações começaram a ser implementadas nos estados, mesmo quando o Ministério da Saúde ainda não tinha proposições para atuação frente a nova doença e até mesmo negava a necessidade de intervenção. A SES-SP foi pioneira ao implantar o seu Programa de DST/ Aids no segundo semestre de 1983, sendo seguida por outros governos estaduais como Rio de Janeiro e Rio Grande do Sul. A política nacional de combate à epidemia começou a ser implantada em 1985, ano de preparação para a $8^{\text {a }}$ Conferência Nacional de Saúde, quando o movimento 
da reforma sanitária começava a debater nacionalmente seu projeto, e também ano da eleição de Tancredo Neves, com diversos quadros do movimento, assumindo postos nas secretarias estaduais de saúde desde 1983 e no Ministério da Saúde a partir de 1985, e quando ainda eram incipientes as possibilidades terapêuticas com relação à aids.

Foi a partir da década de 1990, com a efetiva definição de dispositivos legais para a implantação do SUS e novas alternativas de medicamentos antirretrovirais, ${ }^{78}$ bem como com a garantia de recursos financeiros através do acordo de empréstimo junto ao Banco Mundial que a política nacional de aids se consolidou. Este capítulo trata do período de 1990 a 2001, abordando a fase de consolidação da política (1990-1996) e de conformação de estratégias para a sustentabilidade da garantia do acesso universal (1997-2001).

\section{Retrocessos e avanços do governo Collor}

A década de 1990 iniciou com o primeiro governo federal eleito de forma direta através do voto popular após o período da ditadura militar: o governo Collor. Marcado pela política neoliberal de redução do Estado, embasada numa reforma econômica e administrativa com importante corte de gastos públicos, o que implicou em grandes entraves para o avanço da Reforma Sanitária e do Sistema Único de Saúde. (FALEIROS et al., 2006) Ainda que tenham sido promulgadas as Leis Orgânicas da Saúde (Lei 8.080/90 e Lei 8.142/90), a publicação da Norma Operacional Básica - NOB o1/91 subverteu diversas conquistas dessas leis. Os retrocessos políticos levaram a uma desmobilização do movimento sanitário, dando espaço para um maior protagonismo dos gestores municipais e estaduais. Ao mesmo tempo, se a legislação ampliou o acesso da população

O AZT (zidovudina) foi registrado no FDA em março de 1987; o ddl (didanosina) em 1991; o ddC (zalcitabina) em 1992; o d4T (estavudina) em 1994; O 3 TC (lamivudina) e o SQV (saquinavir) em 1995; o RTV (ritonavir), o IDV (indinavir) e oNVP (nevirapina) em 1996; o NFV (nelfinavir), DLV (delavirdina) e o AZT+3TC em 1997; o EFV(efavirenz) e o ABV (abacavir) em 1998; APV (amprenavir) em 1999; o LPV (lopinavir+ritonavir), o ddiE (didanosina entérica e o ABV+AZT+3TC em 2000; e o TNV (tenofovir) em 2001. 
aos serviços públicos de saúde, houve uma redução da ordem de cerca de $50 \%$ dos recursos destinados à saúde. (PAIM, 2008)

Foi nessa conjuntura que Alceni Guerra ${ }^{79}$ assumiu o Ministério da Saúde, nomeando para Secretário Nacional de Assistência à Saúde Ricardo Ackel, ${ }^{80}$ que convidou para assumir a Divisão Nacional de Aids o médico Eduardo Jorge Bastos Côrtes, professor da UFRJ desde 1977, instituição na qual se formou e fez Residência em Terapia Intensiva, com mestrado em Oncologia pela Universidade da Califórnia (UCLA), um dos principais centros de estudo de aids do mundo, onde estudou as neoplasias da aids. Côrtes havia retornado dos EUA expressando uma posição de oposição à política nacional, com algum destaque na imprensa. Na sua opinião, a estratégia governamental menosprezava a expansão e a heterossexualização da epidemia, bem como a identificação do HIV-2 no país e a necessidade de implementar ações de prevenção e tratamento. (“AFRICANIZAÇÃO”..., 1988; CÔRTES..., 1988; OPERÁRIOS..., 1988) Alceni pretendia manter Côrtes sob "rédeas curtas", pois considerava que Lair Guerra tinha “autonomia excessiva”. (RÉDEAS..., 1990, p. A-4)

A forma como foi conduzida a troca de dirigentes, com Lair Guerra recebendo a notícia da sua exoneração pelos jornais, causou constrangimento na equipe ${ }^{81}$ levando ao afastamento voluntário de quase todos seus integrantes. (E15; E27)

79 Médico formado pelo UFPR (1972), com Pós-Graduação em Pediatria também pela UFPR (1973-1974), Chefe do Serviço de Medicina Social do Inamps da agência da Previdência Social em Pato Branco (1976-1979), Superintendente Regional do Instituto de Assistência Médica da Previdência Social do Estado do Paraná (1979-1982), elegeu-se Deputado Federal em 1983-1987 pelo PDS-PR e em 1987-1991 pelo PFL-PR; e Prefeito do Município de Pato Branco-PR, 19972000, também pelo PFL. Ministro de Estado de Saúde, 1990-1992, durante o governo Collor.

80 Médico, Professor Assistente da UFPR (17/06/1980-20/11/1997), Diretor do Hospital de Clínicas da UFPR (1986-1990), Presidente do Inamps e Secretário Nacional de Assistência à Saúde, durante o governo Collor de Melo (1990-1992).

81 [...] muita gente saiu, acho que foi mais por questão de fidelidade, como tudo se processou. Porque eu trabalhei diretamente com a Dra. Lair desde a criação. Ela fica sabendo que não é mais diretora por um jornal do Rio de Janeiro. [...] Ela ficou sabendo por alguém do Rio de Janeiro que ligou pra ela e disse: 'Olha, quem vaiser o novo coordenador éo Eduardo Côrtes.' [...] a gente achou que não foi uma maneira política e correta de se exonerar uma pessoa que se dedicou a essa luta, brigou pela luta. [...] eu não ia me sentir a vontade com uma pessoa que eu não conhecia, teve seus méritos claro, mas eu não conhecia. Então, como eu era do 
[...] as pessoas ficaram com medo de serem demitidas. Então todo mundo se ajeitou. Como gente saiu de outros lugares e veio também. Então, eu recebi aquilo realmente arrasado, porque de quarenta e poucas pessoas, ficaram lá, quatro. E [devido] a reforma administrativa, eu só ia poder ter uma secretária, que era no organograma das divisões que foi uma briga grande que eu tive lá, uma secretária e dois assessores. Eu tinha três DAS pra dar. [...] eu fiquei inicialmente com menos de 10 pessoas. (E7)

Além da conjuntura de reforma administrativa, a mudança de governo também implicou em uma descontinuidade para a política de aids, não apenas relacionada à entrada de um novo gestor e aos cortes de recursos do setor saúde, mas devido ao esvaziamento da equipe, a perda do status de prioridade, ${ }^{82}$ além do acesso limitado do novo gestor do programa ao ministro, pelo menos até o início do segundo semestre de 1991, quando a situação do programa foi apresentada ao ministro em uma reunião.

O Alceni Guerra incluiu a aids dentro das prioridades do ministério depois da famosa reunião que eu disse em público que o Programa de aids estava aquém das necessidades para o controle da epidemia no Brasil. Foi uma reunião fechada, mas pública, com todo Estado maior e Estado menor. Na hora que eu fuifazer o meu relato, eu tive a coragem de dizer isso pra ele. E ele ficou danado da vida, interrompeu a reunião e saiu. No dia seguinte ele recomeçou a reunião e ele não me demitiu. Ele até valorizou isso e incluiu a aids na reunião estratégica que ele tinha às segundasfeiras [...]. Foi quando teve a grande mudança da aids no Brasil, que eu já tinha ido ao Banco Mundial e ele incluiu a aids e a agente acertou tudo. (E7)

Eduardo Côrtes, um jovem pesquisador que estudava a soroprevalência em populações vulneráveis à infecção pelo HIV, foi visto inicialmente como uma possibilidade de revitalização do Programa Nacional cuja gestão anterior era criticada pelo tecnicismo e centralização. (PARKER, 2003)

quadro do ministério, preferi me ausentar esse momento até para não atrapalhar o trabalho dele aqui e deixar ele mais a vontade pra montar a equipe dele como ele quisesse. (E15)

82 [...] antes, como eu te disse, não era prioridade. Na semana que eu entreiteve uma entrevista do Alceni Guerra, no Rio, que ele veio pedir à Xuxa, que na época estava no auge, pra fazer parte na campanha de crianças, né? De diarreias, desnutrição infantil e tal. Ea imprensa sempre perguntando sobre aids. Ele falou assim "Que aids? Aids não é um problema. Problema é diarreia e mortalidade infantil'. (E7) 
Contudo, sem conseguir se articular com os pesquisadores da Fiocruz, dominantes no campo científico, e com a oposição das ONGs em reação à campanha veiculada em $1991,{ }^{83}$ mesmo com bons relacionamentos nos EUA, Côrtes permaneceu isolado. Ou seja, se no espaço aids norte-americano ele relacionava-se com o pólo dominante ligado à oncologia, no Brasil seu capital científico, no interior do espaço aids, era restrito. A oncologia, sua especialidade de origem, não teve papel preponderante na resposta à epidemia da aids no Brasil, como teve nos EUA. De forma que Côrtes, até aquele momento, ao interior do espaço aids no Brasil, era um recém-chegado tanto no campo científico quanto no campo burocrático, desconhecendo as normas e os trâmites da tecnoburocracia estatal. Assim, foi a partir do momento em que assumiu a posição no ministério, onde começou a ganhar experiência na gestão. Além disso, tinha como fator complicador a ausência de prioridade dada pelo Ministro à epidemia da aids.

No período de março de 1990 a janeiro de 1992, quando Eduardo Côrtes esteve na direção do programa, não aconteceram reuniões da Cnaids. (BRASIL, 1994a; PROGRAMA NACIONAL DE DST E AIDS, 2003)

É importante ressaltar que a gestão de Côrtes iniciou-se quando a aids era manchete nas capas de revistas voltadas para o público feminino, como Contigo e Amiga, nas quais houve a divulgação de casos de artistas brasileiros, portadores de HIV/aids, a exemplo do cantor e compositor Cazuza e do ator Lauro Corona. A veiculação constante de notícias e a exposição de imagens quase que semanalmente em diferentes fases da doença, desde o diagnóstico - 1987 e 1988, respectivamente - até a morte dos artistas 1989, Lauro Corona e 1990, Cazuza - permitiram um acompanhamento da evolução da doença, evidenciada e materializada nos seus corpos. O preconceito em admitir a doença também apareceu, percebido através da reclusão e da omissão de informações ou na exposição dos fatos pela família e pelo próprio doente. (FAUSTO NETO, 1991) Da mesma forma, em 1991, foi massivamente divulgado, em âmbito internacional, o afastamento das quadras do jogador de basquete Magic Johnson, portador de HIV/aids.

83 As ONGS consideravam a campanha ameaçadora pelo apelo ao medo da aids e do doente de aids, assim como criticava a omissão do governo federal frente à epidemia de aids. 
Naquele período, houve, segundo o então coordenador do programa, uma tentativa de reestruturação da Comissão Nacional, incluindo a participação de esportistas e artistas, com objetivo de lhe dar maior visibilidade.

[...] eu sugeri que se criasse uma Comissão Nacional de Aids não de profissionais de saúde apenas, mas uma comissão da sociedade. Então quem ia fazer parte dessa sociedade? [...] Peléaceitou ser o presidente da nova Comissão Nacional de Aids e a gente começou a chamar pessoas da indústria, dos meios de comunicação, do meio científico. Então, o Pelé, vou te dar exemplo de algumas pessoas, muito conhecidas, representantes da sociedade. O Pelé, a Hebe Camargo, o João Araújo, que era o pai do Cazuza, que era uma pessoa muito influente nos meios, não era um homem público, mas era o cara que controlava a Som Livre, que era a maior gravadora brasileira [...]. O Paulo Ayrosa Galvão, que era o diretor do Hospital Emílio Ribas em São Paulo, queéo maior hospital de aids do Brasil. O Walter Clark, ele era um homem de TV também, ele tinha sido o executivo principal da Globo muitos anos e estava dirigindo as redes de TV educativas. Eu acho que ele tinha se aposentado, saído da Globo, mas era uma pessoa assim... [...] ele era brasileiro, de reconhecida competência nos meios de comunicação, enfim, eu tenho isso escrito e outras pessoas da área, tanto científica como... aí começou a ter um burburinho de gente querendo participar dessa comissão. (E7)

Essa proposta significaria uma mudança na composição da comissão e no seu caráter. A Cnaids passaria de uma comissão de especialistas dos campos médico, burocrático e do espaço associativo para uma comissão de personalidades/ pessoas famosas, talvez com maior visibilidade e capacidade de sensibilização da sociedade brasileira, mas com menor poder técnico e científico e mesmo com pouca representatividade dos diversos grupos, o que poderia resultar inclusive em uma menor legitimidade frente à elaboração da política e do discurso oficial. Contudo, com o retorno de Lair Guerra, em março de 1992, essa comissão não chegou a se concretizar. As pessoas chegaram a ser contatadas, a comissão foi divulgada no discurso do presidente Collor em comemoração ao dia mundial de combate à aids em 30 de novembro de 1991, mas não chegou a ocorrer nomeação dos membros ou reunião dessa comissão. 
O Boletim Epidemiológico também sofreu alterações na sua apresentação e na sua proposta editorial na gestão de Côrtes. Nos anos iniciais (1987-1989), o boletim era um veículo de comunicação do Programa Nacional que, além das informações epidemiológicas, apresentava textos acerca das principais questões em discussão, orientações do Programa Nacional, recomendações da Comissão Nacional, resultados de pesquisas ou mesmo análises da situação epidemiológica. Sua publicação era mensal, sempre relativa a quatro semanas epidemiológicas e impressa em papel branco nas cores vermelha e preta. ${ }^{84}$ (Figuras 3 e 4) Os dois primeiros números da gestão de Eduardo Côrtes mantiveram o formato anterior, trazendo a tradução de artigos publicados em revistas internacionais, além dos dados epidemiológicos.

A partir do $\mathrm{n}^{\circ} 10$, do ano III, referente às semanas epidemiológicas 14 a 22 de 1990, com objetivos de reduzir custos e buscando se assemelhar ao padrão internacional adotado pela OMS e pelos EUA, o Boletim Epidemiológico começou a ser impresso em tamanho ofício na própria gráfica do ministério, apresentação que só foi modificada no ano 2000, quando o meio eletrônico passou a ser a principal forma de difusão do boletim. A maior modificação foi na proposta editorial: o boletim passou a apresentar apenas os dados epidemiológicos consolidados em tabelas, sem qualquer relato, análise ou divulgação técnica de assuntos relacionados à epidemia da aids. (Figura 5) O editorial do Boletim $\mathrm{n}^{\mathrm{o}} 11$ informava que apresentaria artigos assinados por especialistas a partir da edição seguinte. O que, contudo, não aconteceu na gestão de Côrtes. O boletim deixou de ser um veículo de divulgação da política de aids e de estudos científicos, ficando restrito à informação epidemiológica consolidada em tabelas. Com o retorno de Lair Guerra, em 1992, foi mantida a forma de apresentação, mas a proposta editorial passou a incorporar novamente análises da situação epidemiológica, relatos de experiências e pesquisas científicas.

De acordo com um dos entrevistados, antes desse Boletim impresso em gráfica foram confeccionados artesanalmente alguns números com as primeiras informações epidemiológicas, contudo esses não foram localizados. (Entrevista concedida por E11, em São Paulo, em 4 de agosto de 2011) 


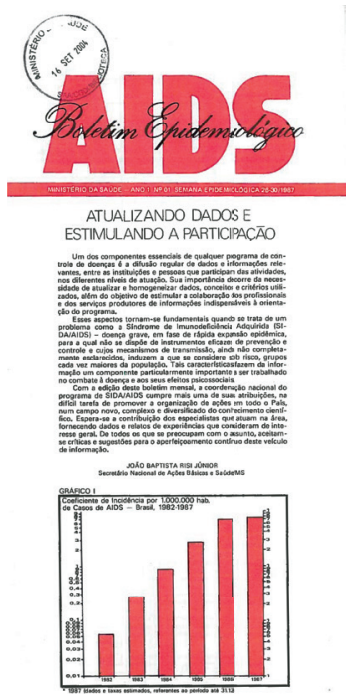

Fonte: Boletim Epidemiológico Aids (1987a).

FIGURA 4-Boletim Epidemiológico, parte interna

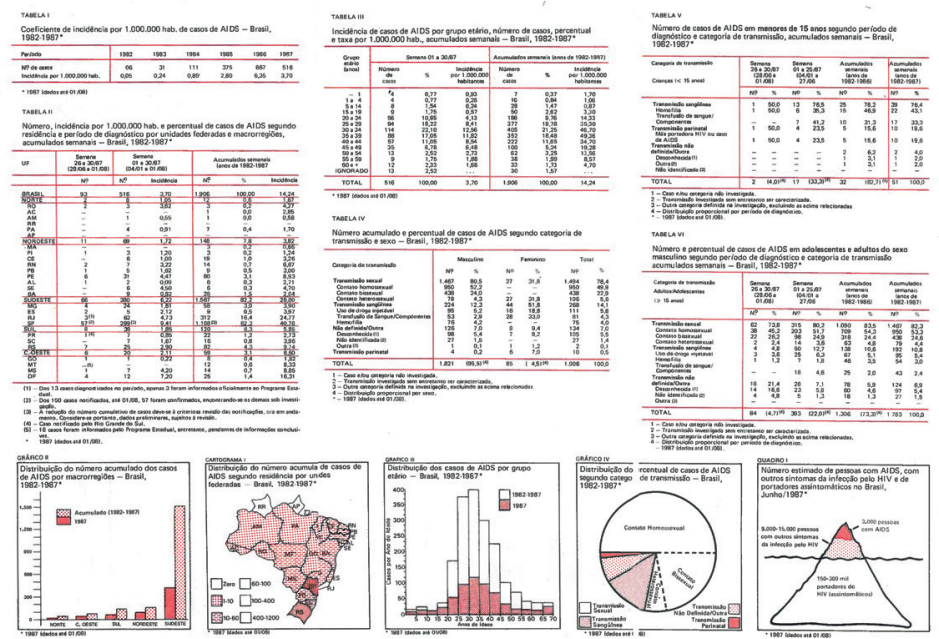

Fonte: Boletim Epidemiológico Aids (1987b). 

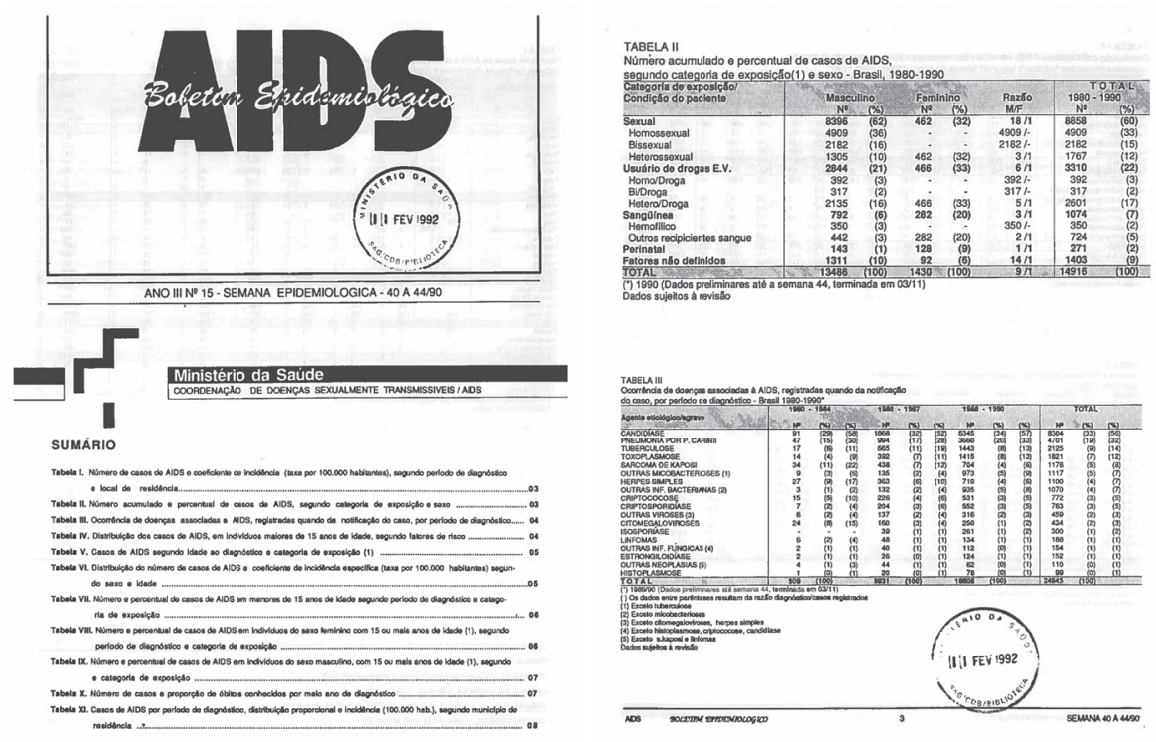

Fonte: Boletim Epidemiológico Aids (1990).

De acordo com Eduardo Côrtes, durante sua gestão, foi realizada uma revisão dos dados e incluído o procedimento de dupla digitação para identificação de erros. Existem referências a um atraso na publicação dos boletins na mudança da gestão de Lair Guerra para a de Côrtes, bem como uma irregularidade da publicação de números de acordo com Parker (2003). A análise dos boletins realizada no presente estudo, contudo, não foi capaz de evidenciar esse atraso, haja vista o período informado nos boletins ser referente às semanas epidemiológicas correspondentes ao período apresentado e não ao momento efetivo da sua publicação.

Com a mudança da equipe técnica, a suspensão das reuniões da Cnaids e a nova abordagem do Boletim Epidemiológico houve uma quebra nos canais de comunicação anteriormente estabelecidos entre Programa Nacional e organizações não governamentais, secretarias estaduais, médicos e pesquisadores, o que pode ter contribuído também para o isolamento do coordenador nacional. 
As críticas das ONGs/Aids estavam associadas principalmente à omissão do governo e à campanha educativa "Se você não se cuidar, a aids vai te pegar", considerada disseminadora de pânico e medo, contendo peças para a TV, a campanha tinha três fases previstas durante o ano de 1991. (GALVÃO, 2000; GOVERNO..., 1990; NASCIMENTO, 2005; PREVENÇÃO..., 1991)

[...] era uma campanha de longo prazo. [...] a gente foi criticado, mas a única avaliação que teve, no Correio Brasiliense, em dezembro de 1990, mostrou que mais de $80 \%$ da população tinha aprovado aquela campanha. Mas os entendidos de aids falaram que era um horror [...] Foi a primeira de uma série programada, em que a gente primeiro ia criar o choque, depois ia fazer a campanha contra o preconceito [...] As pessoas não queriam que a gente falasse isso. Não pode falar que a aids não tem cura. [...] Tirando as doenças infecciosas, amigdalite, pneumonia, tuberculose, sífilis, gonorreia, o que você cura? Você não cura diabetes, você não cura hipertensão arterial, você não cura cirrose, você não cura enfisema. A gente usava 'não tem cura', como nenhuma tem, mas não queriam dizer isso, e era aquela coisa, aquela dificuldade. [...]. (E7)

$\mathrm{Na}$ primeira fase, foi veiculado um filmete de 30 segundos com algumas pessoas falando, no estilo depoimento, cuja ideia, de acordo com E7, era “[...] comparar três doenças conhecidas com essa doença nova” e mostrar que todos são vulneráveis ao vírus, portanto deveriam se cuidar.

Eu tive tuberculose, eu tive cura.

Eu tive sífilis, eu tive cura.

Eu tive câncer, eu tive cura.

Eu tenho aids, eu não tenho cura.

Nos próximos dias, nos próximos meses, no próximo ano, milhares de pessoas vão pegar aids e vão morrer. Se você não se cuidar, a aids vai te pegar! (Campanha "Se você não se cuidar, a aids vai te pegar", 1991)

Essa primeira peça publicitária devido aos inúmeros protestos por parte das ONG/Aids, permaneceu pouco tempo no ar, segundo texto veiculado no endereço eletrônico do próprio Ministério da Saúde no qual 
está o vídeo. ${ }^{85}$ Vale destacar que esse é o único vídeo cujo texto explicativo refere a qual era o governo e o gestor do Programa Nacional à época da sua produção e a repercussão da campanha entre as ONGs, apresentando Eduardo Côrtes como diretor do Programa de Conscientização da Aids, termo não localizado em qualquer material do Ministério da Saúde ou na imprensa, que àquela época ainda era Divisão Nacional de DST/Aids, o que evidencia a relação conflituosa com o grupo que o sucedeu na gestão do Programa. (Figura 6)

FIGURA 6 - Endereço eletrônico do Departamento Nacional de DST, Aids e Hepatites Virais que apresentava o vídeo da campanha "Se você não se cuidar a aids vai te pegar", com destaque no texto que faz referencia ao governo e ao diretor do Programa Nacional à época

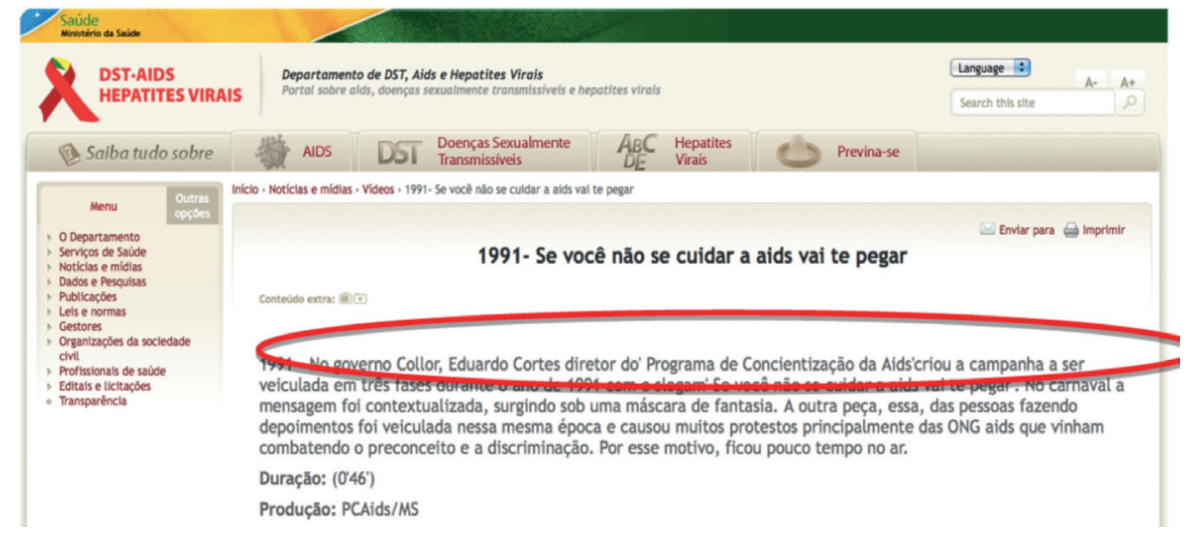

Fonte: $1991-$ SE VOCÊ... (1991).

A segunda fase da campanha tinha o objetivo de reduzir o preconceito e a discriminação dos portadores de HIV/aids: “abraço não dá aids, carinho não dá aids, respeito não dá aids, e terminava assim aids não tem cura, mas preconceito tem" (E7), enquanto a terceira fase abordaria as formas de transmissão da doença - relação sexual, agulhas e seringas compartilhadas, transfusão sanguínea e transmissão vertical. (CÔRTES, 1991) (Figura 7) A crítica dessa vez estava relacionada ao fato da campanha não tratar

85 Cf.SEVOCÊ..., 1991. 
do uso do preservativo como principal forma de prevenção. (LEIA..., 1991) Foi um período em que as ideias do gestor da política nacional não estavam em consonância com a opinião das ONGs e de especialistas que vinham se destacando no enfrentamento à epidemia no país, bem como, de pouca participação e articulação entre a burocracia estatal e os demais subespaços envolvidos na resposta à aids no Brasil. No final de 1991, o governo brasileiro negou-se a participar de um ensaio de vacinas na fase I, primeira que testa a vacina em humanos, junto com Uganda, Tailândia e Ruanda. (SAÚDE..., 1991) Conforme relatado pelo então coordenador, já havia ocorrido uma reunião três meses antes, com participação de representantes da OMS, na qual foi negociada a participação do país em um esforço conjunto com países da Europa e Estados Unidos. (E7)

Contudo, como o documento apresentado pela OMS, em dezembro de 1991, falava em transferência para a OMS da administração da pesquisa de vacinas no Brasil e definia os pesquisadores que iriam acompanhar a pesquisa, sem consulta prévia ao Ministério da Saúde, o ministro Alceni Guerra não aceitou participar nessas condições (SAÚDE..., 1991), posição à qual se opuseram as ONGs, que enviaram ao Ministério da Saúde um documento solicitando a continuidade do diálogo com a OMS e elaboraram a primeira edição ou o número zero do Boletim Vacinas Anti-HIV/aids, editado por um conjunto de ONGs (BELOQUI, 2003; DOSSIÊ..., 1992)

Paradoxalmente, nesse período se pode destacar pelo menos dois fatos importantes para a consolidação da política de controle da epidemia de aids no Brasil:

- O início da distribuição de AZT, pentamidina e ganciclovir pelo Ministério da Saúde em 1991. (SAÚDE..., 1991; TEIXEIRA, 1997)

- O início das negociações para o primeiro acordo de empréstimo junto ao Banco Mundial. (E7, E9; E27) ${ }^{86}$

Foi também nesse interim que ocorreu o primeiro pronunciamento de um presidente em cadeia nacional de rádio e TV sobre aids, em 30 de 
FIGURA 7 - Cartaz da campanha "Se você não se cuidar, a aids vai te pegar", esclarecendo as vias de transmissão

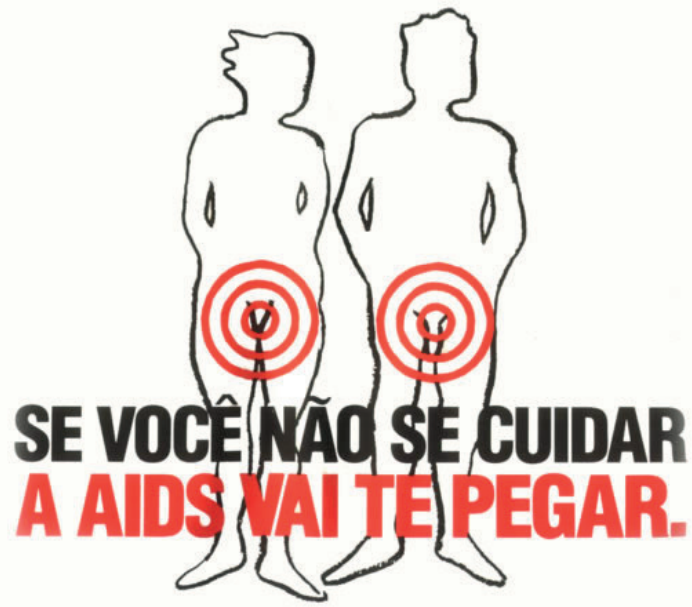

(2) ATRAVÉS DE RELACÃO SEXUAL

COM QUALQUER PESSOA CONTAMINADA.

(2) ATRAVÉS DE AGULHAS E SERINGAS CONTAMINADAS.

() NA TRANSFUSÃO OU CONTATO COM SANGUE CONTAMINADO.

(2) DA MÃE CONTAMINADA PARA O FILHO, DURANTE A GRAVIDEZ OU NO PARTO. 
novembro de 1991, em razão do dia mundial de combate à aids $-1^{\circ}$ de dezembro. (ANEXO C)

Mesmo que a decisão do Ministro Alceni Guerra em adquirir e disponibilizar medicamentos para a aids na rede pública tenha se dado em um momento de pressão e sem uma articulação prévia com outros setores do governo, ${ }^{87}$ como o Ministério do Orçamento, Planejamento e Gestão, que a oferta de medicamentos tenha sido escassa e irregular e que o acordo de empréstimo só tenha se efetivado em 1993, esses acontecimentos estruturaram a base para a consolidação da política nacional de aids na gestão seguinte. Pode-se destacar que a entrada de um médico clínico na gestão do Programa Nacional, com experiência prévia no tratamento de pacientes com HIV/aids em uma realidade diferente da brasileira, com acesso de medicamentos para o tratamento dos doentes, associado à pressão da mídia e das ONGs, contribuiu para o início da implantação de uma política nacional de acesso a medicamentos para o tratamento da aids. A incipiência da política, naquele momento, pode estar relacionada aos limites do desenvolvimento tecnológico de uma terapêutica eficaz e à irregularidade da oferta.

O pronunciamento do presidente Collor em cadeia nacional de TV e rádio foi o primeiro, e talvez o único, de um presidente abordando a questão da aids, o que evidencia a priorização da questão pelo governo federal a partir do segundo semestre de 1991. Aproveitando o interesse manifestado pelo presidente que passou a questionar o Ministro da Saúde sobre a doença, E7 diz que sugeriu o pronunciamento no dia $1^{\circ}$ de dezembro de 1991.

87 Eu fizuma previsão de custos e de remédios, eu tinha isso pronto. No dia que o Alceni me chamou lá porque a televisão estava lá e ia cobrar dele e ele me perguntou quanto custaria os remédios, eu disse '30 milhões de dólares'. [...] Foi a primeira vez que eu conversei com ele. Ele mandou me chamar lá correndo. [...] A nossa média de sobrevida era 6 meses. [...] Eu vias pessoas morrerem aos quilos, não tinha remédio, não tinha nada, não éAZT, eu estou falando de remédio, não tinha remédio pra tuberculose pras pessoas, porque não tinham previsto isso. Não tinha remédio pra tratar Pneumocystis carinii. Matava assim... você via as pessoas morrerem por falta de remédio! Aquele negócio, eu me sentia péssimo. Por isso que eu quis tanto organizar essa questão. [...] Não apenas do AZT, antes do AZT, eu já tinha conseguido aprovar pra tratar todas as infecções dos doentes de aids e isso foi assim uma mudança enorme. As pessoas estavam cegas, não tinham remédio, as pessoas morriam de Pneumocystis carinii, ficavam alérgicas ao Bactrim que era o que tinha e não tinha pentamidina. Não tinha, não tinha, simplesmente não tinha. (E7) 
[...] eu falei com o Alceni Guerra que era importante pro $1^{\circ}$ de dezembro, que o presidente da república devia falar sobre aids. [Ou] Ele poderia entrar para a história como alguns presidentes que se omitiram. Eu falei isso pro Alceni e ele falou pro Collor. E o Collor resolveu fazer o pronunciamento à nação pra comandar as comemorações do 10 de dezembro de 1991. (E7)

O discurso ocorreu no dia 30 de novembro, na noite anterior ao Dia Mundial de Combate à Aids, devido a uma viagem do presidente para a Colômbia no dia seguinte. O texto foi elaborado pelo cerimonial do Itamaraty, assessorado pela Coordenação de DST/Aids do Ministério da Saúde.

[...] dois jovens diplomatas que iam lá, que eram a interface do presidente comigo, [...] eles é que iam lá com o discurso do Collor, pra escrever junto comigo, e eu recheava a questão técnica. Foram três vezes com esse discurso, nas três eu colocava 'falar de camisinha', nas três o Collor tirou, entendeu? Não falou de camisinha. Mas eu colocava. [...] Eles iam lá 'e aí? Você tem que aprovar o discurso dele', eu recheava, recheava, colocava os gráficos e aí o Collor fez uns bonequinhos, fez lá os gráficos pra mostrar... Foi isso que aconteceu. Foio Itamaraty. Isso foicoordenado, provavelmente, pelo Marcos Coimbra, que era o Embaixador, que era acho o chefe da casa civil dele [...] E eu fiz a parte técnica do discurso. (E7)

O texto foi publicado na íntegra pelo jornal Folha de São Paulo, no dia $1^{\mathrm{o}}$ de dezembro (ANEXO C), Collor dizia que falava enquanto pai de dois adolescentes e Presidente da República. O texto dava destaque a questões técnicas, seus modos de transmissão e sua epidemiologia, apresentando informações sobre essa doença considerada uma emergência médica. A aids era caracterizada como uma doença sem cura, mas evitável, em expansão, que, apesar de ter acometido no início dos anos 1980 principalmente indivíduos do sexo masculino com práticas homossexuais, já apresentava, naquele momento, maior participação de heterossexuais e usuários de drogas injetáveis, predominando, entre esses últimos, adolescentes de 13 a 19 anos, bem como avanço para municípios de menor porte. Ou seja, a aids era apresentada como uma doença que ameaçava toda a população, em especial, os adolescentes. O texto destacava ainda a figura 
do soropositivo e a possibilidade de disseminação da doença através de milhares de pessoas que não sabiam estar contaminadas, mas poderiam transmitir a doença. $O$ discurso era contra o preconceito e a discriminação, promovia uma atitude cristã, de misericórdia e ajuda aos doentes, defendia a permanência dos doentes no exercício profissional, mas não mencionava o uso de preservativo - sexo seguro - como uma das formas de prevenção e afirmava que "a promiscuidade é uma forma de comportamento que atenta para a própria vida”, evocando a questão moral. Foram apresentadas as ações que o governo federal estava implantando:

- O estabelecimento de um programa de prevenção e assistência;

- A constituição da nova Comissão Nacional de Aids que teria por presidente o jogador Edson Arantes do Nascimento, o Pelé, com objetivo de "mobilizar a sociedade para essa importante missão de combate à epidemia";

- A distribuição de medicamentos, inclusive o AZT; e

- A descentralização do combate à epidemia para os municípios, através da criação de comissões municipais específicas. ${ }^{88}$

Por fim, conclamava toda a sociedade civil a se engajar na luta contra a aids e que a guerra contra a aids seria vencida "com a ajuda de todos e de cada um dos brasileiros, e, acima de tudo, com a ajuda de Deus”. A ambiguidade permeava todo o discurso, que dava ênfase ora à explicação técnica, clara e desprovida de preconceitos, ora ao componente religioso, a moral, e evidenciava o preconceito a determinadas práticas sexuais e mesmo ao modo de vida. Guerra levou a proposta de criar programas municipais de aids, como já havia sido implantado para outras doenças. [...] Ele mandou uma carta pra cada prefeito do país, eu que coordenei essa operação, falando sobre aids, da necessidade de se criar um programa nas cidades. (E7) 


\section{Da resposta samaritana à Pastoral da aids: a nova atuação da igreja}

A década de 1990 marcou o posicionamento da igreja católica voltada para a "resposta samaritana" (ARNS, 1995), baseada na compreensão, misericórdia, solidariedade e ajuda aos que sofrem, promovendo informações sobre a doença, a assistência aos enfermos, amigos e familiares, levando à formação de casas de apoio e atendimento domiciliar a soropositivos (CNBB, 1997; GALVÃO, 1997; PARKER, 2009), bem como o posicionamento contra a discriminação, como pode ser observado no caso da menina Sheila. (Quadro 7)

QUADRO 7-Caso Sheila

Em maio de 1992, a Confederação Nacional dos Bispos do Brasil (CNBB) repudiou a orientação do Sindicato dos Estabelecimentos de Ensino do estado de São Paulo (SIEEESP) de recusar como alunos crianças portadoras de HIV/aids. A decisão surgiu como resultado da consulta da escola Ursa Maior, que não aceitou a matrícula da menor Sheila Caroline Cortopassi de Oliveira, de 5 anos, que já frequentava a escola, depois de ter conhecimento que a menina era portadora do vírus HIV. O caso teve ampla divulgação na mídia. Além da CNBB, o médico Vicente Amato Neto, consultado pela justiça paulista, e a Sociedade Brasileira de Infectologia, representada pelo seu presidente Paulo Augusto Ayrosa Galvão e seu vice-presidente, André Vilella Lomar também se posicionaram contra a posição do SIEEESP e contra a discriminação dos portadores de HIV/aids. Sheila recebeu uma bolsa do Colégio São Luiz, tradicional colégio católico de São Paulo.

Fonte: Biancarelli (1992) e Galvão e Lomar (1992).

Apesar de pregar que a aids poderia atingir qualquer pessoa através da contaminação sanguínea, o discurso da CNBB continuava carregado de preconceito. A proposta era de uma educação sexual que resgatasse “a visão sadia da sexualidade humana", incentivando "a viver a fidelidade na união do homem com a mulher no matrimônio, superando formas de 
promiscuidade e libertinagem". (CNBB, 1997) Ponto de vista que se contrapunha àquele dos homossexuais, que priorizavam o prazer.

Embora o discurso não classificasse a homossexualidade como doença, a abordagem deixava clara essa visão. Excluídos os casos de contaminação através do sangue, a adoção de comportamentos baseados em valores de uma moral religiosa seria a única alternativa segura para evitar a doença. Nesse sentido, associava o sexo ao pecado e a aids era compreendida como uma punição. Considerava que o objetivo das campanhas promovidas por órgãos públicos e outras instituições era "transformar práticas de risco em práticas mais seguras”, mas que não eliminavam o risco da contaminação, o que só seria alcançado através da adoção dos princípios da moral cristã com relação ao valor da sexualidade, do seu uso e de sua abstinência. (CNBB, 1997)

Em 1995, D. Paulo Evaristo Arns passou a classificar o uso do preservativo como "um mal menor", ainda que não recomendasse o seu uso indiscriminado e tratasse a sexualidade como algo negativo. Sua fala também apontava para a adoção de uma linguagem mais popular, usando o termo camisinha, que a própria igreja católica considerava inapropriado nas primeiras campanhas.

Eu não recomendaria simplesmente a camisinha. Mas eu diria se, por exemplo, marido e mulher, que tem direitos, direito absoluto ao ato conjugal, se um deles tem [aids], então, é claro que deve prevenir, para que o outro não seja contaminado. Porque entre os dois males, sempre se deve escolher o menor. Agora, dizer, recomendar a todo mundo: 'Use camisinha e faça'..., não é? Olha, ela não é segura! Há 30\% de perigo de, sobretudo as nossas, 30\% de perigo. Em segundo lugar, o sexualismo desenfreado não ajuda a nação a crescer. Em terceiro lugar, nós, como governo, ou como igreja, ou como instituição, nós não temos o direito de dizer ao outro: 'Olha aqui, você pode fazer o sexo à vontade, desde que você se previna'. Eu acho que cada um tem que educar-se para que a vida em família seja realmente a base da sociedade. (ARNS, 1995)

No final do ano de 1997, o “irmão” Henrique Sá se destacou em uma visita de técnicos do Ministério da Saúde no estado do Amazonas. Tratava-se 
de um caboclo amazônico e pessoa vivendo com HIV/aids, que fundou um centro de atividades e de convivência em Manaus. Enfatizava a diferença entre proclamar e garantir direitos. Irmão Henrique foi o responsável pelas primeiras articulações entre o Programa Nacional, representado pelo seu diretor Pedro Chequer, e o presidente da CNBB, Dom Jaime Chamelo, que resultaram na criação da comissão de DST/Aids da Pastoral da Saúde em 1999. (CNBB, [20--]; COSTA FILHO, 2004) Em 2001, a comissão foi desvinculada da Pastoral da Saúde, sendo legalizada a Pastoral da Aids, tendo como bispo referencial Dom Eugênio Rixen. A Pastoral da Aids era um serviço de prevenção ao HIV e assistência aos soropositivos assumido pela igreja cujo logotipo unia dois símbolos: a cruz que representava a solidariedade e o laço vermelho, símbolo internacional da aids.

Assim como aconteceu com a política Estatal, que incorporou os princípios e diretrizes do que vinha sendo desenvolvido nos estados, na década de 1990, a CNBB incorporou no seu discurso o que já vinha sendo executado no nível local desde a década de $1980 .{ }^{89}$

\section{O papel do Banco Mundial na consolidação da política}

Apesar de não existirem provas documentais acerca da articulação do primeiro acordo de empréstimo em 1991, os relatos de agentes que ocupavam posições distintas e até mesmo opostas, no sentido de participarem de polos diferentes na disputa pela dominância no espaço aids (E7, E9 e E27), convergem nesse sentido.

89 Apesar dos avanços na relação entre Programa Nacional e igreja católica, em 2012, questões religiosas interferiram na divulgação da campanha prevista para o carnaval. Voltada para os jovens homossexuais de 15 a 24 anos, grupo que apresentou 10\% de aumento no número de casos entre 1998 e 2010, enquanto entre os heterossexuais do mesmo grupo etário houve redução de 20\% (BOLETIM..., 2011), a peça apresentava dois homens homossexuais e tinha como slogan "Na empolgação pode rolar de tudo. Só não rola sem camisinha. Tenha sempre a sua”. Mesmo após o lançamento da campanha no Rio de Janeiro com exibição do vídeo, a peça veiculada na TV pelo Ministério da Saúde foi substituída por outra na qual um casal heterossexual falava de dados estatísticos que mostravam o crescimento da infecção entre jovens gays e da redução do uso do preservativo. O veto teria vindo do Palácio do Planalto segundo o Departamento de DST/Aids e Hepatites Virais do Ministério da Saúde, e era atribuído ao receio do governo em contrariar grupos religiosos. A informação foi negada pelo Ministro da Saúde, Alexandre Padilha. (FORMENTI, 2012) 
Quando o programa de aids passou a ser prioridade no Ministério da Saúde, sabe, aí nós fomos incluídos para o financiamento do Banco Mundial." (E7)

Uma outra coisa que o Alcenifez, foi aceitar uma proposta do Banco Mundial para firmar um acordo de empréstimo para o 'PN'. Ele indicou, isso eu quero dizer sem provas documentais, o Edmur Pastorello, para negociar junto ao Banco. O Edmur me chamou. Foi o Edmur e eu que fizemos a carta de intenção para apresentar ao Banco, com 'palpites' do Pedro Chequer. [...] O Acordo de Empréstimo com o Banco Mundial só foi assinado, que passa pelo Senado, o Ministério da Fazenda e tudo mais, pelo Ministro Adib Jatene, mas foi uma iniciativa do Ministro Alceni Guerra. A verdadeira iniciativa, por parte do Banco Mundial, foi da Maureen Lewis, uma norte-americana que passou a adolescência aqui no Brasil. (E9)

Em 1991. Na época, Edmur Pastorello, que é da USP, trabalhava como assessor do ministério para o Alceni Guerra. Ele convidou o Euclides. Eu era uma pessoa anátema, por que antes eu trabalhei [...] como diretor do Cenepi, na época do cólera. E como o ministro Alceni Guerra quis esconder os óbitos, eu denunciei, [...] ele me mandou para o Acre, não podia me demitir porque eu era estável no governo e ai o Euclides me chamou escondido porque ele não podia saber que eu estava envolvido. Ai se fez as duas, três primeiras páginas do que seria o embrião do projeto de acordo do Banco Mundial, que o Dr. Adib Jatene assumiu. [...] Nós fizemos uma reunião no prédio da Funasa, no anexo que ficou a Funasa, onde depois passou a ser Cenepie agora não sei o que émais, não é mais Cenepi por que Cenepi não existe mais. E ai nós discutimos alguns princípios e tal, que o Pastorello utilizou e depois o Pastorello continuou com o Adib porque como era da USP, terminou continuando e a coisa aconteceu do primeiro acordo de empréstimo. (E27)

O Banco Mundial já havia financiado, através do Projeto Nordeste, um montante de 7,4 milhões de dólares para o controle e prevenção da aids, recurso que permitiu a elaboração de campanhas veiculadas na imprensa e de materiais educativos, bem como aquisição de equipamentos e materiais para bancos de sangue e laboratórios de saúde pública, contribuindo para a estruturação do Programa e na preparação do acordo de empréstimo específico. (THE WORLD BANK, 1997) Mas foi o Brasil que buscou o Banco para o financiamento da sua política de HIV/aids, em um momento 
em que este ainda hesitava em financiar ações relacionadas à epidemia da aids, não considerado um investimento produtivo por parte dos economistas. (BEYRER; GAURI; VAILLANCOURT, 2005) O financiamento de projetos específicos para controle da aids pelo banco estavam restritos ao Zaire (1989) e à Índia (1991), ainda que diversos projetos incluíssem componentes para o controle da aids e DSTs. (THE WORLD BANK, 1993)

Com inúmeras denúncias de irregularidades, o ministro Alceni Guerra deixou o cargo em 23 de janeiro de 1992. O Ministério da Saúde foi assumido interinamente pelo Ministro da Educação, o físico José Goldemberg, que acumulou as duas funções até 13 de fevereiro, quando o médico cardiologista Adib Jatene assumiu o cargo. (VAZ, 1992)

Eduardo Côrtes permaneceu no Programa Nacional até a chegada de Jatene, quando foi substituído pela sua antecessora, Lair Guerra. A permanência de Edmur Pastorello ${ }^{90}$ na assessoria ao Ministro Adib Jatene teria permitido a continuidade do processo de negociação junto ao Banco Mundial e, sob a coordenação de Lair Guerra, o projeto foi concluído, tendo contado com a consultoria de vários ativistas na sua elaboração. O projeto seguiu então para tramitação na Câmara dos Deputados e no Senado.

Com o impeachment do presidente Collor no final de setembro e a entrada de Itamar Franco, iniciou-se um novo período na saúde, mas mesmo com a troca de Ministros, ${ }^{91}$ Lair Guerra manteve-se na coordenação do Programa Nacional de Aids.

Médico sanitarista e professor doutor do Departamento de Epidemiologia da Faculdade de Saúde Pública da USP. Entre 1980 e 1983, foi diretor Divisão Nacional de Doenças CrônicoDegenerativas (DNDCD) do Ministério da Saúde, e superintendente da Campanha Nacional de Combate ao Câncer, de 1980 a 1985. Foi diretor do Instituto de Saúde da SES-SP entre 1987 e 1989, e secretário geral do Ministério da Saúde de 1989 a 1990. Em 1992, foi Diretor de Operações da Fundação Nacional de Saúde e depois Chefe de gabinete do Ministério da Saúde, função que assumiu também entre 1995 e 1996. Na SES-SP, em 1993 coordenou os Institutos de Pesquisa, entre 1997 e1999 assumiu a coordenadoria de Planejamento de Saúde, e em 1999 foi assessor técnico de gabinete. Entre 2002-2003 foi diretor técnico-científico da Fundação Oncocentro de São Paulo, da qual foi diretor-presidente entre 2003 e 2011. (INCA, 2012)

91 Durante o governo Itamar Franco, no período de outubro de 1992 a agosto de 1993, o Ministro da Saúde foi o médico Jamil Haddad, sucedido pelo também médico Henrique Santillo, que permaneceu no cargo até o final do governo Itamar em 1 de janeiro de 1995. 
O primeiro acordo de empréstimo junto ao Banco Mundial foi assinado em 1993, após duas missões do Banco, ${ }^{92}$ a primeira realizada em outubro de 1992 e a segunda em janeiro de 1993.

Também conhecido como AIDS I, o projeto tinha como objetivos gerais a redução da incidência e transmissão do HIV e de DSTs; e o fortalecimento de instituições públicas e privadas responsáveis pelo controle de DSTs e HIV/aids, através de um aporte financeiro de 250 milhões de dólares, 160 milhões do Bird e 90 milhões do governo federal, distribuídos em 4 componentes:

1. Prevenção (U\$93,9 milhões): programas de informação, educação e comunicação voltados para o público geral e grupos de alto risco; ampliação da capacidade de diagnóstico, aconselhamento, testagem e intervenções precoces; aquisição e distribuição de preservativos;

2. Serviços (U\$75,7 milhões): serviços de saúde para pacientes com HIV/aids e DSTs; integração de prevenção e serviços médicos ao aconselhamento visando melhorar e reduzir os custos da assistência;

3. Desenvolvimento institucional ( $\mathrm{U} \$ 42,3$ milhões): treinamento de profissionais de saúde, melhoria de serviços laboratoriais e assistência técnica; e

4. Vigilância, Pesquisa e Avaliação (U\$14,6 milhões): ${ }^{93}$ vigilância epidemiológica, avaliação do programa e estudos especiais, incluindo análises epidemiológicas, de custos, e impacto econômico do HIV/ aids. (BEYRER; GAURI; VAILLANCOURT, 2005; THE WORLD BANK, 1993)

A primeira missão composta por M. Lewis (líder da missão), M. Jacobs (analista de operações), R. Hoffman (oficial de operações), J. Wilson (consultor), K. Holmes (consultor), M. Moore (consultor), E. Ayres Castilho (consultor) eS. Dompieri (consultor); a segunda, por M. Lewis (líder da missão), M. Jacobs (analista de operações), J. Wilson (Consultor), C. Bertao (assessor sênior), E. Ayres Castilho (consultor), S. Dompieri (consultor), D. Schopper (consultor) e F. Zacharias (consultor).

Um montante de U\$23,5 milhões foi reservado para contingências físicas e de preço. 
O maior volume de recursos estava alocado no componente Prevenção, corroborando a política do banco, que não aconselhava o investimento em tratamento para países em desenvolvimento. Assim, banco e governo chegaram a um acordo com relação à política de fornecimento de medicamentos antirretrovirais: o banco não concordava com o fornecimento de AZT garantido pela política brasileira, visto que considerava o tratamento caro e não efetivo, e exigia a redução de taxas de importação para preservativos, permitindo uma redução do preço final ao consumidor. (BEYRER; GAURI; VAILLANCOURT, 2005)

\section{[...] Esseéum dos artigos que nós estamos trabalhando desde o primeiro momento, desde 1991, 92, 93, a gente já defendia que tratamento era prevenção, que o acesso ao tratamento era prevenç̧̃̃o. (E3O) $)^{94}$}

Um indicador importante da qualidade e efetividade do serviço para o Banco Mundial foi a baixa prevalência de resistência a medicamentos ARVs (6,6\%) documentada por um estudo ${ }^{95}$ realizado em 2003 no Brasil. (THE WORLD BANK, 2004a) Até 2012, contudo, não havia sido monitorada a possibilidade de reversões de comportamentos - no sentido de comportamentos de maior risco - em consequência do programa de tratamento bem-sucedido do país.

Os resultados obtidos levaram inclusive o grupo de avaliação do banco a ratificar a importância do fornecimento de medicamentos ARVs, quando considerou que tanto o AIDS I como o AIDS II, assinado em 1998, foram fundamentais para investimentos em capacitação para tratamento e assistência que viabilizaram a sua adoção. (THE WORLD BANK, 2004a)

O primeiro acordo de empréstimo foi executado entre os anos de 1994 e 1998, tendo importante papel no estabelecimento de financiamentos para as ONGs, Estados e municípios e na criação de uma estrutura adequada ao funcionamento do programa, tornando-o capaz de induzir de fato uma política nacional, inclusive legitimando atividades controversas

94 Entrevista concedida por E30, médica infectologista e diretora IPEC/Fiocruz, no Rio de Janeiro, em 14 de junho de 2011. 
de prevenção como a redução de danos, ${ }^{96}$ trabalho com presidiários e programas para profissionais do sexo. (BEYRER; GAURI; VAILLANCOURT, 2005; THE WORLD BANK, 2004a)

O segundo acordo de empréstimo, o AIDS II, vigente entre 1999 e 2002, teve um custo total de U\$296,6 milhões, 99\% do estimado - 300 milhões de dólares, sendo 165 milhões do Bird e 135 milhões do governo federal. Apesar de não ter recursos para medicamentos, teve investimentos para promover hospitais-dia, assistência domiciliar terapêutica, e outros serviços a pacientes não internados; diminuir o custo de preservativos, através de redução de impostos e outros meios; implantar um sistema de monitoramento e avaliação; e fortalecer a gestão de estados e municípios, devolvendo algumas responsabilidades. (THE WORLD BANK, 2004a)

O governo tornou-se fonte importante de financiamento para as ONGs. Com o AIDS I (1994-1998), 181 ONGs receberam financiamento para 444 projetos na área de prevenção, nos quais foi mais importante a atuação dessas organizações, e 140 projetos de tratamento e assistência, superando a meta inicial de 261 projetos financiados, o que foi viabilizado devido à redução do teto de financiamento de U\$ 100.000 para U\$ 50.000, devido à constatação que poucas ou nenhuma das ONGs tinha capacidade para usar aquela quantia. No AIDS II (1999-2002) esse número foi ainda maior. Foram financiadas 795 instituições, que executaram 2163 projetos - 1709 de prevenção e 454 de tratamento e assistência. (THE WORLD BANK, 2004a)

O aumento de casos entre usuários de drogas injetáveis a partir de 1989 levou à primeira iniciativa de programa de trocas de seringas, na cidade de Santos, São Paulo, com o médico Fábio Mesquita à frente do Programa Municipal. Porém a implantação da medida foi questionada pela Procuradoria do Município de Santos, baseada nos artigos 12 e 13 da Lei 6368/76, que trata das medidas de prevenção e repressão ao tráfico ilícito e uso indevido de substâncias que causem dependência física ou psíquica, considerava que a prática de troca de seringas estaria incentivando ao uso de drogas e, portanto, seria um delito, levando ao adiamento do programa de troca de seringas. A Secretaria de Saúde do estado de São Paulo, desde o início da década de 1990 também já vinha desenvolvendo estratégias de redução de danos, mas limitados pelajustiça paulista, apenas orientavam a limpeza das seringas com hipoclorito de sódio, o que era insuficiente. Assim, em 1995, Salvador foi a primeira cidade do Brasil a ter um programa de troca de seringas. Na sequência, outros estados e municípios começaram a criar legislações próprias, e apenas em 2002 foi aprovada a nova lei de drogas no país, permitindo "ao Ministério da Saúde regulamentar as ações que visem à redução de danos sociais e à saúde”. (BRASIL, 2002, Art. 12) 
Os projetos de assistência e tratamento executados por ONGs referiam-se a alojamento para pacientes em tratamento fora do domicílio, grupos de apoio, reinserção social, apoio para geração de renda, apoio domiciliar, apoio psicossocial, serviços de saúde mental e assistência voltados para a avaliação e aderência à terapia antirretroviral, além da criação de casas de apoio para pessoas vivendo com HIV/aids. (THE WORLD BANK, 2004a)

Verifica-se um aumento considerável do número de ONGs financiadas entre o primeiro e o segundo acordo de empréstimos. Ainda que não tenha sido possível realizar uma análise mais criteriosa acerca da ampliação do número de ONGs/Aids a partir do AIDS I, alguns entrevistados destacam ter surgido diversas organizações que se tornaram dependentes do financiamento governamental.

Os recursos oriundos dos projetos AIDS I e II teriam contribuído para a melhoria da qualidade dos serviços de diagnóstico, tratamento e assistência para pessoas com HIV/aids e DSTs, e sua expansão para todas as unidades federativas. Além de fomentarem o fortalecimento e a criação de coordenações estaduais nos 27 Estados e 150 coordenações municipais, os projetos também permitiram as primeiras transferências financeiras diretas para governos estaduais e municipais. Essas transferências estavam condicionadas à elaboração de planos operativos de ação (POA). Foram criados 237 centros de testagem e aconselhamento (CTA); foi desenvolvida uma rede de serviços especializados de saúde para pacientes com HIV/ aids; houve um fortalecimento do sistema de laboratórios para monitoramento e acompanhamento de pacientes; foram desenvolvidos softwares para gerenciamento e controle da distribuição e do uso de medicamentos antirretrovirais (Siscel e Sisclom); e realizados treinamentos de profissionais de saúde e outros quadros técnicos. (THE WORLD BANK, 2004a)

$\mathrm{Na}$ visão de alguns membros da Abia, como Raldo Bonifácio, João Guerra, Jane Galvão, Rogério Gondim, Alvaro Matida, Gerson Noronha, Richard Parker e Nelson Solano Vianna, “com esse projeto, o Ministério manifesta sua intenção de superar - de uma vez por todas, esperamos - os 10 anos de imobilismo e irresponsabilidade governamental que permitiram a desenfreada propagação do HIV em nosso país". (SCHWARZSTEIN, 
1993) Contudo, demandavam uma gestão democrática, transparente e eficaz, acompanhada por uma Comissão Nacional que pudesse efetivamente exercer o papel de controle social; e consideravam o AIDS I um "atalho metodológico" à elaboração de uma proposta de Programa Nacional adequada ao perfil epidemiológico, desconhecido devido à não realização de estudos de soroprevalência anteriores; questionavam a impossibilidade de compra de medicamentos e remuneração de profissionais e a capacidade de cumprimento da contrapartida financeira pelo Estado brasileiro e criticavam também o tempo exíguo para a elaboração da parte do projeto referente a cada estado.

O tempo que nos foi dado [...] foi extremamente curto. [...] Tudo foi feito a toque de caixa. Mesmo as pessoas responsáveis pela Coordenação do programa Estadual de DST e AIDS estavam desinformadas. As exigências eram grandes e as planilhas que recebemos foram decifradas com enorme dificuldade. O pessoal encarregado de coordenar o processo tentou descentralizar e democratizar, tentou conseguir o maior envolvimento possível por parte dos serviços públicos e das ONGs e isso foi bom... Aconteceu que por falta de tempo e de orientação suficientes muitos dos projetos que recebemos dos serviços públicos não tinham cabimento. [...] O que acontece é que a principal carência dos serviços já existentes diz respeito à falta de pessoal e de medicamentos, e que o Projeto do BM não contempla este tipo de necessidade. (BONIFÁCIO, 1993, p. 9)

Quando questionados acerca do significado dos acordos de empréstimo para o Programa Nacional, os entrevistados de todos os subespaços destacam a sua importância para a estruturação do Programa Nacional, relacionada à contratação de técnicos, financiamento de projetos de ONGs e projetos de pesquisa, na opinião de agentes do campo científico; à melhoria da rede de assistência, melhoria da governança e da gestão, e a possibilidade de contratação de bons profissionais, de acordo com os militantes e na visão dos agentes do campo burocrático; a possibilidade de financiamento de ONGs e transferência de recursos para estados e 
municípios, realização de inquéritos, priorização de populações vulneráveis e aquisição de equipamentos como computadores. (Figura 8)

Vale destacar que, em 1996, o sociólogo Betinho achava que, mesmo com o financiamento do Banco Mundial, o Programa Nacional ainda não estava consolidado, queixando-se principalmente com relação à insuficiência da assistência e tratamento no país e à dificuldade de acesso aos medicamentos, evidenciando um ponto de vista crítico de esquerda acerca da política nacional. ${ }^{97}$

Outro ponto destacado por agentes dos subespaços burocrático e científico foi a questão da manutenção da autonomia nacional frente à tentativa de indução de políticas pelo Banco Mundial que considerava a prevenção como única via para países em desenvolvimento. (Figura 8)

Essa autonomia esteve presente desde o início, quando Lair Guerra não aceitou a criação de uma gerência do projeto paralela ao Programa Nacional, prática frequente nos acordos de empréstimos do Banco Mundial, e foi fundamental para o fortalecimento do Programa Nacional de Aids. (E27)

Obanco queria estabelecer uma gerencia do projeto do Banco Mundial [...]. A Lair foi dura com isso, não aceitou, e onde isso aconteceu o programa não subexistiu. [...] Isso não funciona. Eu estive na Argentina e também apoiei o Banco na formação do projeto da Argentina e lá eles fizeram a gerência do projeto LUSIDA e o Programa de Aids do nível nacional, do Ministério da Saúde. O programa nunca conseguiu deslanchar, o projeto acabou e o programa não se beneficiou [...] (E27)

Nesse sentido, posteriormente, em 2005, na segunda gestão de Pedro Chequer, o país recusou um recurso da ordem de U\$40 milhões da U.S. Agency for International Development para aquisição de preservativos, por discordar da exigência de condenação da prostituição, como previsto nas leis norte-americanas. Tal condição foi rejeitada pelo diretor do publicadas no Boletim ABIA, n. 31, jan./abr. 1996. 
FIGURA 8 - Concepções dos entrevistados acerca do significado dos acordos de empréstimo junto ao Banco Mundial para o Programa Nacional de DST/Aids, segundo subespaços de inserção dos agentes

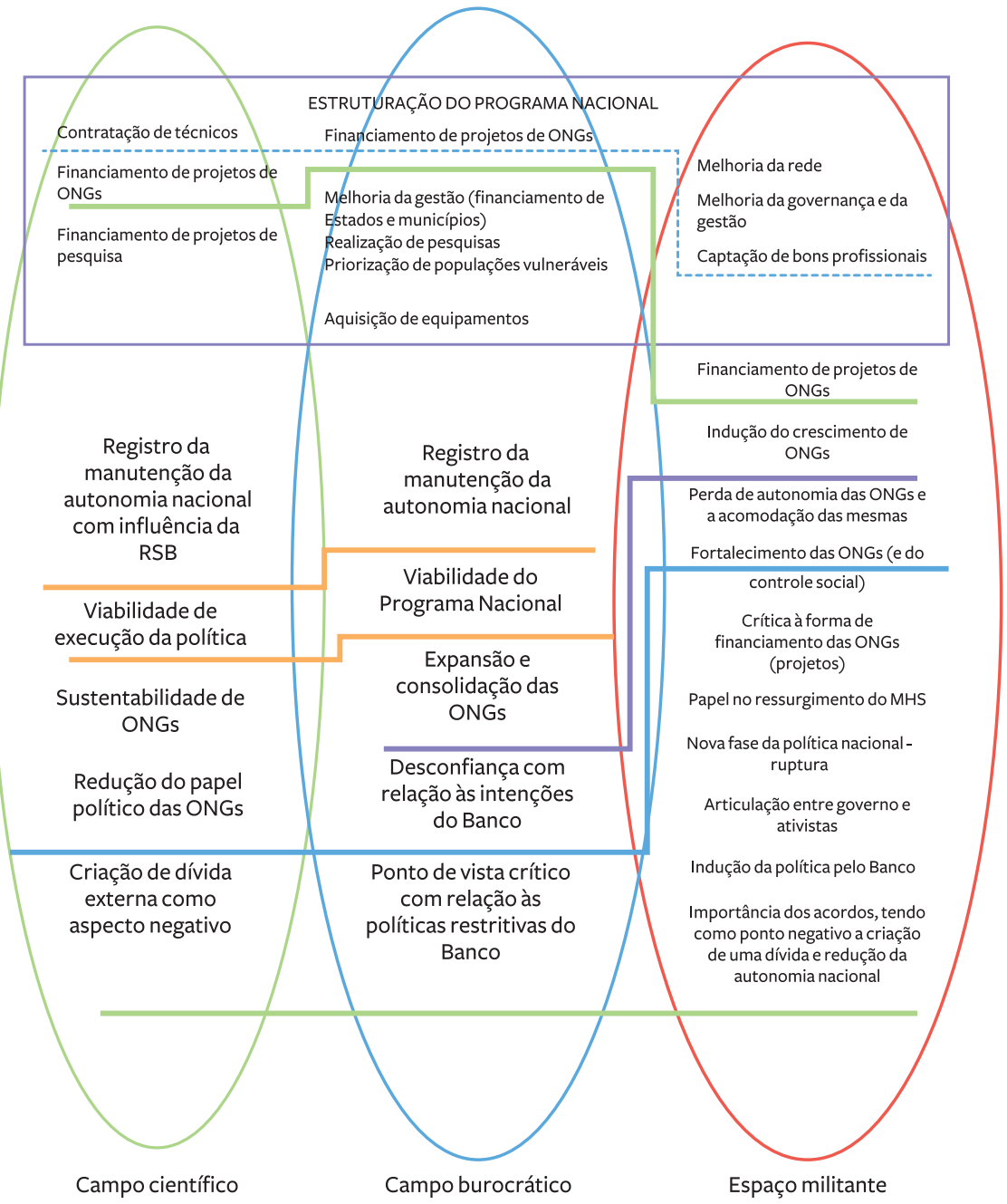

Fonte: Elaborada pela autora.

Nota: $O$ Apêndice $D$ apresenta as falas dos agentes que resultaram na elaboração dessa Figura. 
programa visto que no Brasil, a prostituição não é criminalizada, ${ }^{98}$ e desde 2002, a ocupação de "profissional do sexo" faz parte da Classificação Brasileira de Ocupações (CBO) na categoria "prestador de serviço" (RODRIGUES, 2009), além dessa categoria profissional ser parceira na execução das suas políticas, inclusive com representação na Cnaids.

O AIDS I marcou uma nova fase para a política nacional de controle da epidemia e também para o espaço aids, determinando uma transformação nas relações entre o campo burocrático e os demais subespaços. Com relação ao espaço militante, com a possibilidade de financiar projetos de ONGs, os recursos do Programa Nacional passaram a representar a sustentabilidade de algumas associações específicas de luta contra a aids, em especial as de menor porte e com menor capacidade de captação de recursos internacionais, gerando uma certa acomodação e em alguns casos dependência do Programa Nacional, o que também garantiu ao Estado maior controle em relação ao espaço aids. O projeto estimulou o diálogo com gays, usuários de drogas injetáveis, profissionais do sexo e, na opinião de Edward MacRae, teve também um impacto importante no movimento homossexual, promovendo o seu ressurgimento, através do estímulo a publicações, campanhas e ações voltadas para esse grupo específico.

Eu acho que ao mesmo tempo que foi uma ajuda grande, deu esse retrocesso. [...] Eu acho que atrapalhou por causa disso, as pessoas se acomodaram com os financiamentos de 30 mil, 40 mil, 50 mil, e pararam de reivindicar qualquer coisa. Ou só fazia isso porque o próprio Ministério dava o título. Então esse ano era mulher, então só vou trabalhar com mulher. [...] A epidemia tem tema? Não, então... Se eles mesmos falam, não tem, não escolhe partido, não escolhe segmento, não tem preconceito com nada, a aids gosta de todo mundo, como éque vai escolher um tema? (E3)

[...] esse financiamento levou, bom, toda essa ideologia do Banco Mundial, levou então o Programa de Aids do Brasil a começar a buscar cada vez mais um diálogo

De acordo com o Código Penal brasileiro (BRASIL, 1940), são crimes: induzir ou atrair alguém à prostituição ou outra forma de exploração sexual, facilitá-la, impedir ou dificultar que alguém a abandone (Art. 228); manter, por conta própria ou de terceiro, estabelecimento em que ocorra exploração sexual (Art. 229) e tirar proveito da prostituição alheia (Art. 230). 
com os gays, inicialmente, e depois com os usuários de drogas. Especialmente com os gays. [...] com esse trabalho, o Banco Mundial e o governo brasileiro, querendo ter contato com os gays e promover essas campanha entre os gays, eles começaram a financiar publicações, a financiar reuniões e isso deu um novo ímpeto para o movimento gay. Então o primeiro movimento gay foi assim uma reação contra os médicos, o segundo movimento já começa, de certa forma, caudatário, e vai perdendo a sua estridência, a sua crítica contra o establishment médico. Porque eles passam de críticos a porta-vozes. [...] Foi o dinheiro da aids que financiou esse ressurgimento do movimento gay. (E8)

O financiamento de projetos de ONGs foi um aspecto destacado por agentes de todos os subespaços. Esse financiamento foi considerado como positivo no sentido de promover uma maior articulação com as organizações não governamentais, possibilitando a expansão do número de associações e a sua consolidação, mas alguns militantes e agentes do campo científico destacaram como aspectos negativos a perda da autonomia das ONGs, a acomodação e a redução do seu papel político. (Figura 8)

As normas do banco só permitiam o financiamento de projetos, não existindo a possibilidade de apoio institucional, como garantido por algumas agências internacionais. Um entrevistado chegou a falar em uma "ditadura do projeto". ${ }^{99}$ O que foi também notado por alguns dos entrevistados foi uma redução das críticas ao Programa Nacional por parte das ONGs, compreendido por alguns como cooptação, mas por outros como um resultado da possibilidade de contratação de militantes/ativistas - garantida pelo acordo de empréstimo - para os diferentes níveis da gestão das políticas de aids, contribuindo para um aumento da capacidade técnica do Programa Nacional e também de programas estaduais e municipais, que associado à estruturação decorrente do aporte financeiro do acordo de empréstimo, possibilitou uma política mais efetiva, da qual eles são partícipes, também contribuindo para a redução das críticas. (Figura 8)

O fato de se tratar de um empréstimo foi destacado como ponto negativo, ainda que compreendido como necessário. Da mesma forma, foram 
citados por E6, casos pontuais de desvios, que na sua avaliação não superariam os benefícios do financiamento.

[...] eu acho que o recurso do acordo, há muita crítica porque o país paga, o país tem que pagar essa dívida, mas tem vários estudos, inclusive feitos por grupos franceses, do uso desses recursos, e que eu acho que eles tem uma avaliação positiva [...] $(\mathrm{E} 16)^{100}$

[...] uma parte dessas ONGs se constituíram por conta do financiamento. Enquanto teve dinheiro, elas funcionaram e na hora que acaba o financiamento, elas fecham. Teve muito problema com ONGs. Eu venho de ONGs eu vejo aqui mesmo, vocêtem desvios que aconteceram, pequenos, acho isso dentro do contexto geral, nós fizemos uma avaliação que é importante continuar financiando mesmo com alguns problemas localizados que aconteceram, mas tem assim, hoje acho que étambém um outro perfil dessas ONGs que estão sobrevivendo e algumas com muita dificuldade. A gente tem, por exemplo, Abia aqui do Rio Janeiro, instituição super-reconhecida, tem um belo trabalho com dificuldade por quê?? Porque ela teve para além do governo federal, muitos outros investimentos de fundações internacionais que hoje diminuíram e no mundo está diminuindo esse investimento. A gente precisa continuar. Esse é o desafio de continuar mantendo a prioridade e o investimento dos países ricos. $(\mathrm{E} 6)^{101}$

Os recursos dos projetos AIDS I e II permitiram iniciar a estruturação da rede de assistência aos portadores do vírus e da rede pública de laboratórios, fundamentais para o apoio à estratégia de acesso aos medicamentos ARV, mas, de acordo com a avaliação do banco, o país não avançou na questão da avaliação das estratégias implementadas. (BEYRER; GAURI; VAILLANCOURT, 2005; THE WORLD BANK, 2004a) No sentido de superar essa situação, em 2003, foi criado um setor de avaliação na Assessoria de Planejamento e Avaliação (Asplav), que elaborou o Plano Nacional de Avaliação (PNA) do PN DST/Aids, que como parte das suas

100 Entrevista concedida por E16, médica epidemiologista e pesquisadora, em Salvador, em 5 de setembro de 2011.

101 Entrevista concedida por E6, diretor adjunto do Departamento de DST, Aids e Hepatites Virais, em Brasília, DF, em 2 de agosto de 2011. 
estratégias promoveu a realização de cursos de pós-graduação - especialização e mestrado profissionalizante - em Avaliação de Programas de Controle de Processos Endêmicos, com ênfase em DST/HIV/aids, oferecidos pela Fiocruz e o sistema de monitoramento do Programa de Controle de DST/Aids e hepatites virais (Monitoraids). (SANTOS; REIS; CRUZ, 2010; THE WORLD BANK, 2004a)

Até 2012, o governo federal havia realizado quatro acordos de empréstimo junto ao Banco Mundial para o controle da aids no país. A análise dos valores desses acordos apontam para uma redução do montante de recursos bem como da participação do banco no acordo, com maior contrapartida federal, denotando o aumento da sustentabilidade e independência financeira da política brasileira de controle da aids. (Quadro 8)

QUADRO 8 - Acordos de empréstimo para o controle da aids, período de aplicação, montante total, participação do Banco Mundial e do Governo Brasileiro, 1993-2010

\begin{tabular}{|c|c|c|c|c|}
\hline $\begin{array}{l}\text { Acordo de } \\
\text { empréstimo }\end{array}$ & $\begin{array}{l}\text { Período } \\
\text { (assinatura-encerramento) }\end{array}$ & $\begin{array}{l}\text { Montante total } \\
\text { (em US\$) }\end{array}$ & $\begin{array}{l}\text { Banco } \\
\text { (em US\$) }\end{array}$ & $\begin{array}{l}\text { Governo brasileiro } \\
\text { (em US\$) }\end{array}$ \\
\hline AIDSI & \begin{tabular}{|c|}
$1993-1998$ \\
\end{tabular} & 250 milhões & 160 milhões & 90 milhões \\
\hline AIDS II & 1998-2003 & 300 milhões & 165milhões & 135 milhões \\
\hline AIDS III & 2003-2007 & 200 milhões & 100 milhões & 100 milhões \\
\hline AIDS-SUS ${ }^{1}$ & 2010-2014 & 200 milhões & 67 milhões & 133 milhões \\
\hline
\end{tabular}

Fonte: The World Bank (199, 2004b, 2008, 2010).

(1) Em 2014, o governo brasileiro assinou um termo aditivo ao acordo de empréstimo, que estendeu o prazo do acordo e cancelou US\$25.150.00o de dólares do valor total do empréstimo, passando ao valor de US\$ 41.850.00. (THE WORLD BANK, 2014)

\section{Cnaids: nova relação de forças}

Pode-se destacar duas fases da Comissão Nacional de Aids, a primeira do início da sua implantação até o início dos anos 1990, quando já existiam as primeiras possibilidades terapêuticas. Neste primeiro momento, a voz dos especialistas que conformavam a Cnaids era muito importante para a construção do discurso oficial e, além do papel consultivo, as tomadas de posição da comissão eram acatadas e repercutiam na condução da política, de modo que a mesma parecia possuir de fato um papel deliberativo, ainda que esse não lhe fosse delegado oficialmente. 
Após a gestão de Eduardo Côrtes (1990-1992), na qual não houve reuniões da Cnaids, a comissão foi retomada na nova gestão de Lair Guerra. Com a maior estruturação da política nacional, entre 1992 e 1993, surgiram outras instâncias de assessoramento ao Programa Nacional, como o comitê de vacinas, a comissão para estudos e ações no sistema penitenciário, o comitê de pesquisa, e um setor específico de articulação com as ONGs, levando a um esvaziamento das funções da Cnaids, que na primeira gestão de Lair Guerra constituía-se como único espaço de discussão e articulação da política.

A Comissão Nacional foi descrita pelos entrevistados como uma instância de assessoria técnica e política ao Programa Nacional. Consultiva, sem poder de deliberação, mas com influência na tomada de decisões em função da sua capacidade técnica, por se tratar de um grupo de experts. Alguns a consideraram como instância de controle social e quase todos destacaram a grande diversidade de atores como um fator positivo. (APENDICE E)

Segundo o ponto de vista de alguns entrevistados, o surgimento dessas novas instâncias estava relacionado à complexidade que a resposta governamental adquiriu, à entrada de novos agentes no espaço aids e aos avanços no saber médico acerca da doença, bem como a formação de uma expertise em diversas áreas. Ou seja, à medida que o espaço aids foi especializando-se, seja no campo médico ou no burocrático, foram surgindo novas instâncias de participação e articulação do Estado com os demais campos e subespaços interessados no controle da epidemia (APÊNDICE E), refletindo as disputas ao interior do espaço entre médicos e sanitaristas e militantes com a criação de espaços técnico-científicos.

A comissão assumiu o papel de construir o discurso oficial, legitimado pelo capital simbólico do grupo que a constituía. Contudo, o avanço do conhecimento médico sobre a doença e o surgimento de uma possibilidade terapêutica no final da década de 1980 levaram a uma alteração significativa da correlação de forças ao interior do espaço aids. Foram criados espaços autônomos de experts, e a participação dos demais grupos passou a ser mais pro forma. Segundo os entrevistados, a diversificação e especialização de comissões tornava mais ágil a discussão dos processos. 
Por outro lado, esse desmembramento em diferentes instâncias de decisão da política, de alguma forma, pulverizou o poder antes concentrado na Cnaids.

Além do aprofundamento da discussão acerca dos aspectos éticos para triagem sorológica do HIV e o plano de vacinas, o tema mais frequente nessas reuniões foi o projeto do acordo de empréstimo junto ao Banco Mundial. Mas “apesar do Projeto do Banco Mundial ter sido ponto de pauta, o tom da discussão era de apresentação do projeto e não de solicitação de apreciação, avaliação e intervenção da Comissão", o que reforça o caráter não deliberativo da comissão. (PROGRAMA NACIONAL DE DST E AIDS, 2003, p.38) O Programa Nacional e o Governo Federal assumiram a responsabilidade da negociação, cabendo à Comissão Nacional o papel de acompanhamento e avaliação da sua execução. (PROGRAMA NACIONAL DE DST E AIDS, 2003)

Segundo editorial do Boletim da Abia, a Comissão Nacional de Aids era

[...] o fórum de maior influência e responsabilidade sobre a formulação e o monitoramento das políticas brasileiras de controle da epidemia de HIV/aids no país [...] o que o país tem de melhor em matéria de especialistas da aids.(COMISSÃO..., 1993, p. 4)

A conjuntura começou a mudar a partir das discussões do primeiro acordo de empréstimo (AIDS I). Pelo caráter da negociação, essa permaneceu a cargo do poder executivo, envolvendo inclusive outras instâncias estatais como a Presidência da República, o Senado Federal, o Ministério do Planejamento, Orçamento e Gestão e o Ministério da Fazenda (BRASIL, 2005), estando fora do escopo das funções da Comissão. Contudo, o papel assumido anteriormente, com forte influência sobre a definição das estratégias técnicas a serem adotadas levou a uma disputa, encabeçada pelo representante da Abia, João Guerra C. Monteiro, pelo papel da Comissão. A Abia criticava a ineficiência da Cnaids no cumprimento das atividades que poderia e deveria desenvolver, principalmente no que tangia ao debate e a reflexão do processo de negociação com o Banco Mundial, de modo que o representante da Abia optou por se afastar da 
Comissão. ${ }^{102}$ (COMISSÃO..., 1993) A participação teria passado a ser meramente formal, na opinião de integrantes da Abia.

A gente acha que a Comissão estava totalmente inoperante, era início do projeto do Banco Mundial, enfim... Toda atenção era o grande projeto que se montava para o Banco Mundial. [...] Ela não conseguia mais influenciar as políticas de aids, não se dava ouvidos e atenção ao que se propunha, e então a Abia efetivamente resolve se afastar como uma maneira de denunciar essa inoperância, vamos dizer assim, da Comissão. $\left(\mathrm{E}_{33}\right)^{103}$

A necessidade de discussão do papel da Cnaids foi reconhecida por todos os seus membros, mas a posição colocada pela Abia do papel da comissão em relação ao Projeto do Banco Mundial não era consenso. Manifestaram-se sobre o posicionamento e/ou saída da Abia ${ }^{104}$ (BRASIL, 1994a, p. 116):

- Jair Ferreira (SES-RJ), que considerava inapropriado o comportamento da Abia, retirando-se antes da discussão das funções da Cnaids, sugerida pelo próprio representante da associação, e episódica a função relacionada ao projeto do Banco Mundial ${ }^{105}$ colocada no documento enviado pela Abia como função da comissão, propondo funções mais gerais;

- Lair Guerra, gestora do Programa Nacional, interpretou a sugestão da Abia para que a comissão não tivesse apenas um papel técnico, mas também político;

- Carlos Alberto Morais de Sá (Hospital Gaffrée e Guinle), Berenice Clemente (MEC) e Eliana de Paula Santos (SESAB) manifestaramse em apoio a Jair Ferreira com relação ao comportamento da Abia;

Ata da reunião da Cnaids de 15 de outubro de 1993.

103 Entrevista concedida por E33, psicólogo e diretor da Abia, no Rio de Janeiro, em 15 de junho de 2011.

104 Ata de reunião da Cnaids de 15 de outubro de 1993.

105

A Abia propunha, entre outras coisas, que a Comissão deveria "criar e impor mecanismos de controle social do Projeto do Banco Mundial”. (COMISSÃO..., 1993, p. 5) 
- Dirceu Greco (UFMG) assumiu posição de apoio à Abia no sentido de que uma comissão forte e independente poderia dar respaldo ao programa;

- Adelmo Turra (Gapa-RS) e Aurea Abbade (Gapa-SP) não concordaram com Jair Ferreira, mas afirmavam também não entender a posição da Abia com relação a sua saída da Comissão;

- Silvia Belluci (Centro Corsini) sugeriu discutir as funções sem considerar o documento da Abia.

Ou seja, a maioria daqueles que se manifestaram não viam motivo para a retirada da Abia da Cnaids, e alguns agentes, em especial aqueles do campo burocrático, exprimiram-se contrariamente ao posicionamento da Abia quanto às funções da Cnaids em relação ao Projeto AIDS I.

As discussões acerca do papel e funcionamento da Comissão Nacional levaram à incorporação de modificações na sua estrutura e composição (BRASIL, 1994b), influenciadas também pela Lei 8.142/90, que definiu os mecanismos de participação da comunidade na gestão do SUS. Foram agregadas novas competências e normalizou-se a participação social, através do acordo de como seria a representação das ONGs/Aids: um total de cinco representantes, dois da região Sudeste, dois das regiões Norte, Nordeste e Centro-Oeste e um da região Sul, escolhidos no Encontro Nacional de ONGs/Aids. ${ }^{106}$ (PROGRAMA NACIONAL DE DST E AIDS, 2003) A Comissão passou a ter as seguintes competências incorporadas na Portaria n. 1.028, de 31 de maio de 1994 (BRASIL, 1994b):

1. Participar na formulação e dar parecer sobre a política de prevenção e controle das DST/Aids;

2. Discutir diretrizes a serem observadas pelo Programa Nacional através dos Planos Operativos Anuais;

3. Identificar necessidades e coordenar a produção de documentos técnicos e científicos; 
4. Assessorar o Ministério da Saúde no desempenho das atividades do Programa Nacional de DST/Aids e participar do redirecionamento de estratégias;

5. Desempenhar papel de articulação política, mobilizando setores do governo e da sociedade civil para a luta contra a epidemia do HIV/aids.

Essa visão da Cnaids como uma instância de assessoria técnica é compartilhada por agentes dos diferentes espaços, contudo, alguns acreditam em uma perda de importância, relacionada a fatores como: o surgimento de outros comitês e comissões, que passaram a constituir espaços de discussões específicas; o aumento da capacidade técnica do quadro de funcionários do Programa Nacional; ou mesmo, os diferentes interesses e estratégias de permanência dos agentes no espaço aids e na própria comissão.

Eu acredito que não é que ela perde importância, mas eu acho que ela tem a função de capilarizar essas questões para outros espaços, [...] então, ela tem outro papel. Eu acho que são papeis diferenciados, mas que se complementam, mas eu não vejo como perdendo força política, acho que são papeis complementares e obviamente questões que inicialmente eram discutidas lá, ela passa a ter um foco pra ser discutido em um determinado espaço e aquela comissão é muito mais política, e as outras têm outras funções. $(\mathrm{E} 13)^{107}$

Com o aumento da capacidade técnica do programa, não só no sentido dos técnicos que estavam lá, mas no sentido de conseguir construir grupos específicos. Então, tinha que discutir, sei lá, os medicamentos antirretrovirais, se montava uma comissão específica, do consenso. Esses comitês e comissões setoriais vão enfraquecendo um pouco esse papel de excelência da Comissão Nacional, embora se

107 Entrevista concedida por E13, técnico do Departamento de DST, Aids e Hepatites virais, em Brasília, DF, em 2 de agosto de 2011. 
mantenha a Comissão Nacional como principal foco, principal estrutura, ela vai gradativamente perdendo esse poder de dizer sobre o Programa inteiro. (E1 ${ }^{108}$

Eu posso te dizer que antes a gente tinha voz. Tinha voz e tinha propostas. Todas as vezes que ia para uma reunião da Cnaids o Gapa sentava antes, discutia os temas, o que ia ser falado, como ia ser falado, a gente mesmo se questionava dias e dias naquilo, então, se levava quase que um documento pronto com vários pontos já discutidos e debatidos. Agora, pelo que eu sei, a coisa já vem pronta para assinar. Aíjá não éo que era. A única coisa que eu acho é que isso aconteceu por causa desse financiamento. Por que as pessoas ficaram? Primeiro porque o Aids-SUS é muito grande. Todo mundo quer viajar, todo mundo quer ficar em hotéis cinco estrelas, coisa que 90\% não sabe nem o que é um hotel [...], quer dizer, a orientação do que discutir não tem, mas tem hotel e isso te compra. Tem a passagem, tem a diária, que pra gente, você pode falar 100 reais não é nada, mas pra quem não recebe nada, vem de avião, volta, a pessoa fica assim boba. (E3)

Refletindo o aumento da complexidade das ações desenvolvidas pelo Programa Nacional e os avanços técnico-científicos, houve também uma ampliação dos temas pautados no período de 1994 a 1998, mas sem a atuação proativa em todos os temas como observado nos períodos anteriores. A prevenção, como já vinha acontecendo no final da década de 1980, estava dirigida a populações específicas. Começou a se discutir o uso do teste rápido, os avanços no tratamento antirretroviral e estratégias para sua utilização adequada, o fortalecimento das ações de descentralização, o aprimoramento da gestão, a questão dos direitos humanos em HIV/aids, os ensaios de vacina. A Cnaids teve participação ativa em dois momentos: a seleção dos Centros de Referência Nacional, onde pesou uma pressão da comissão para participar da operacionalização do Projeto AIDS I (16 de março de 1994); e na atuação junto ao Ministro para cobrar a compra emergencial de medicamentos (31 de maio de 1995). (PROGRAMA NACIONAL DE DST E AIDS, 2003) Nos dois casos, relacionado principalmente aos representantes de ONGs.

Entrevista concedida por E1, sociólogo e coordenador do Programa Nacional de DST/AIDS, em São Paulo, em 21 de junho de 2011. 
Com os avanços na terapia antirretroviral, entre 1999 e 2001, as discussões concentraram-se principalmente na assistência e nas ações de prevenção, as reuniões tornaram-se mais informativas das ações do Programa Nacional, havendo momentos nos quais foram discutidos temas emergentes como tecnologias reprodutivas e a não recomendação de um medicamento homeopático para tratamento da aids (o Canova). O processo de descentralização e a sustentabilidade das ações, temas que permeavam o projeto AIDS III, ficaram a cargo do Comitê Técnico Assessor de Gestores (Coge), ${ }^{109}$ criado em 2000. (PROGRAMA NACIONAL DE DST E AIDS, 2003)

Vale destacar que desde 1990, era o Conselho Nacional de Saúde a instância colegiada do SUS que tinha caráter deliberativo acerca da formulação de estratégias e no controle da execução da política de saúde, inclusive com relação aos aspectos econômicos e financeiros. (BRASIL, 1990) De modo que, embora tenha tido papel fundamental na definição do discurso oficial e na formulação da política de controle da aids na primeira década da epidemia, diversos fatos estabeleceram uma nova ordem no espaço aids brasileiro. Pode-se citar: os avanços do conhecimento médico e científico sobre a doença aids; o estabelecimento de medidas terapêuticas eficazes para o tratamento e controle da doença; a entrada de novos agentes nesse espaço de luta pela organização da resposta à epidemia de aids no país, como gestores estaduais e municipais e representantes da indústria farmacêutica; e a regulamentação das instâncias de participação popular na gestão do Sistema Único de Saúde nos anos 1990. Além disso, o advento do primeiro acordo de empréstimo colocou a aids como uma questão de governo. Esses fatos levaram à criação de novas instâncias de participação dos agentes de diferentes subespaços e à redistribuição e pulverização de forças entre essas instâncias. Essa reorganização define o espaço médico, técnico e burocrático nas subcomissões, separando-os

O Coge foi criado pela Portaria n. 992 do Ministério da Saúde, de 1 de setembro de 2000. Assim como a Cnaids, também é uma instância consultiva do Programa Nacional, tendo também o papel de promover a articulação entre os gestores dos três níveis de governo (federal, estadual e municipal) para a incorporação das ações de DST/Aids no processo de descentralização da saúde. 
do espaço militante ocupado pelas ONGs, que saíram enfraquecidas no seu papel político, havendo um deslocamento para o campo burocrático.

É interessante notar que as novas instâncias como Comitê de Vacinas e Comitê Assessor para Terapia Antirretroviral, seguem o modelo adotado pela própria Cnaids em várias situações em que havia a necessidade da discussão de questões específicas para as quais era constituída uma comissão de experts para a definição da posição oficial sobre assuntos específicos.

\section{O acesso universal aos ARV e o reconhecimento internacional}

O acesso universal à terapia antirretroviral no Brasil foi alcançado através de um processo para com o qual contribuíram agentes dos diferentes subespaços, em especial dos movimentos sociais. Quando o AZT foi aprovado pelo Food and Drug Administration (FDA), ${ }^{110}$ em 1987, em seguida, alguns pacientes no Brasil começaram a fazer uso através do contrabando do medicamento que ainda não possuía comercialização autorizada no país. Geralmente a compra era solicitada a comissários de voo da Varig ou da Vasp ou a pessoas que viajavam ao estrangeiro que traziam o medicamento em suas bagagens (E3; E12; E18; ${ }^{111} \mathrm{E}_{33}$ ), ou mesmo a importadoras. (E1; E18) Os compradores eram pacientes ou ONGs, como o Gapa-SP, mas o acesso ainda era muito restrito visto que o AZT ainda não estava disponível no Brasil. (SOUZA, 1987)

[...] a gente comprava desde o Zovirax, o AZT, tudo, mesmo comprando fora, mas a gente comprava ou ganhava. Uma pessoa do sul, uma vez, eu me lembro, nós tínhamos um paciente aqui, aí eles mandaram do sul para cá. Um mandava 15 comprimidos, outro mandava 10 [...] O que sobrava, vinha e a gente redistribuía. E o pessoal da Vasp, se eu não me engano, que ajudou muito trazendo de fora. [...]

Agência governamental americana responsável pela regulação e supervisão de alimentos, medicamentos, suplementos alimentares e outras substâncias.

111 Entrevista concedida por E18, matemático, fundador do Pela Vidda-SP, Membro Abia, diretor GIV e pesquisador Nepaids, em São Paulo, em 18 de junho de 2011. 
o Antônio Angarita que era o presidente. [...] ele dava essas passagens de cortesia para a gente. Quer dizer, a gente fazia os ofícios endereçados a ele, se era ele que dava ou não. [...] Pra a gente viajar para lá e para cá, e em uma dessas viagens, os meninos conheceram esses pilotos e aí esses pilotos que tinham viagens internacionais compravam e depois a gente dava dinheiro. Eu só sei que era em dólar. Aí a gente dava o dinheiro, eles compravam e repassavam para a gente ou para os pacientes que tinham grana. Era assim. (E3)

A normalização da venda do AZT no Brasil aconteceu a partir de 8 de outubro de 1987, sete meses após a aprovação pelo FDA nos EUA, quando a Divisão de Medicamentos (Dimed) publicou portaria ${ }^{112}$ com essa finalidade, questão que foi inclusive debatida na Cnaids. Mas o acesso ao medicamento ainda ficou restrito àqueles que tinham condições financeiras para arcar com o seu alto custo, numa época de hiperinflação e grande oscilação do câmbio. A divulgação da medida foi anunciada através de informe publicitário da indústria farmacêutica, publicado na Folha de São Paulo. No informe, o diretor da Wellcome no Brasil, Ricardo Lobo, falava como um agente do Estado, usando o nome da Dimed e do Ministério da Saúde. (Figura 9)

Ah, era um saco, porque era assim: a Glaxo [Wellcome] estava em Cotia, você tinha que comprar e eles vendiam em dólares, no câmbio do dia. E era uma época de inflação altíssima! Então você tinha que fechar o câmbio do dia, ir no banco, fazer boleto bancário, tudo formal, sabe? Mandava isso... Acho que era isso, boleto bancário ou cheque administrativo, só sei que era uma burocracia dessa, acho que boleto bancário. Eaí eles entregavam na sua casa. [...]. (E18)

Em 1989, no Encontro Nacional de ONGs/Aids (Enong) de Porto Alegre, foi elaborada a Declaração dos direitos do soropositivo (ANEXO A) que trazia entre outros pontos o direito de acesso à assistência e tratamento. A compra de AZT começou a ser realizada por alguns Estados de

BRASIL. Ministério da Saúde. Portaria $n^{\circ} 18$, de 6 de outubro de 1987 . Baixa instruções com vistas a normatizar a venda, em estabelecimentos, de medicamentos a base da substância azido timidina (AZT). 
FIGURA 9 - Transcrição do informe publicitário do laboratório Wellcome, publicado no jornal a Folha de São Paulo acerca do registro do AZT no Brasil, em 26 de novembro de 1987

\section{COMUNICADO SOBRE O “RETROVIR” (AZT) À CLASSE MÉDICA E ÀS AUTORIDADES SANITÁRIAS}

A Divisão Nacional de Vigiância Sanitária de Medicamentos (DIMED), do Ministério da Saúde, autorizou, por despacho do dia 9/11/87, o registro do "Zidovudine", sob a marca "Retrovir", também conhecido como "AZT". Esse medicamento, fabricado exclusivamente pelos laboratórios da Wellcome na Inglaterra e nos E. U.A., após anos de pesquisa, envolvendo 80 milhões de dólares, é o único tratamento atualmente disponivel em todo o mundo para pacientes portadores da Sindrome da Imunodeficiência Adquirida (AIDS). Com a aprovação do registro sanitário, deverão, agora, ser preenchidas as outras formalidades, necessárias à comercialização do produto no Brasil.

Enquanto isto, comunicamos:

1. No intuito de proporcionar aos pacientes brasileiros acesso ao medicamento pelo menor custo possivvel, estamos pleiteando junto às autoridades fazendárias federais e estaduais, a isenção dos impostos de importação (já concedida), IOF, ICM, PIS/FINSOCIAL

Do mesmo modo, estamos solicitando ao CIP - Conselho Interministerial de preços - a fixação do preço do "Retrovir" no mercado interno.

2. Colocannos à disposiçã̃o da classe médica e das auturidades saritárias unn serviço permarnente de informações técnicas a respeito do produto, sua aplicação e os resultados alcançados nos demais países que utilizam o "Retrovir".

3. Tão logo as autoridades concedam as demais isenções solicitadas a Wellcome estará em condições de fornecer "Retrovir" à classe médica, aos hospitais e outras entidades brasileiras credenciadas a atender portadores de AIDS.

4. Comunicamos, por fim que hospitais e outras instituiçõos interessados em importar diretamente o produto poderão fazê-lo pelo preço de importação uniforme, para todo mundo, de US\$188,00 por frasco de 100 cápsulas, $\mathrm{FOB}$, porto ou aeroporto de embarque na Inglaterra.

Para informações: Caixa Postal n 503 - CEP 06700 - Cotia - SP

Telex 1171729

Telefone (011) $492.3155-$ r. 300

RICARDO LÔBO

Diretor

Fonte: Wellcome (1987). 
forma incipiente, ${ }^{113}$ em especial devido a ações judiciais. A distribuição de medicamentos para doenças oportunistas acontecia desde 1988, de forma muito tímida, e a partir de 1991 teve início a distribuição de AZT. (PROGRAMA NACIONAL DE DST E AIDS, 2005)

\begin{abstract}
Então, eu comecei em 9o. Porque eu comecei em outubro, final de outubro, porque eu tive uma queda um pouco de CD4. [...] eu tive leucoplasia pilosa, então um amigo disse 'Ah, você tem que começar!'. E depois de um tempo me inseriram, porque eu não sei se eu estava, porque eu não tinha aids, felizmente eu não desenvolvi, mas não sei se eu tinha direito, mas eu comecei a tomar igual pelo serviço público. (E18)

[...] não tinha uma regularidade assim, ou logística de compra e de entrega, não era uma coisa muito regular. Mas em 1991, que até foi na breve passagem do Eduardo Côrtes no Programa que se começou, se aumentou o fornecimento de AZT. [...] Depois, em 1992, quando o Eduardo saiu, já se manteve. (E3O)
\end{abstract}

A distribuição de medicamentos ARV pelo Ministério da Saúde não era uma proposta inicial, nem em 1988, na gestão de Lair Guerra, nem do presidenciável Fernando Collor de Mello em 1989, que em consulta realizada pelo Gapa junto a cinco dos candidatos a presidente, considerava que a aquisição do AZT deveria ser encargo dos doentes, das empresas, das instituições privadas de assistência e de fontes não exclusivamente governamentais. (CANDIDATOS..., 1989; DROGA..., 1988) Mas pressionado pela imprensa, o Ministro Alceni Guerra terminou cedendo à aquisição de AZT pelo governo em 1991.

Apesar da disponibilidade de medicamentos como AZT, pentamidina e ganciclovir desde àquele momento, conforme noticiado na imprensa e confirmado através de relatos de usuários e profissionais, o tratamento apenas com o AZT, ou monoterapia ainda era pouco eficaz. (COHEN, 1993; SELIGMANN et al., 1994) nas $7 \%$ dos pacientes. (PROGRAMA NACIONAL DE DST EAIDS, 2005) 
[...] o AZT matava antes da doença. Os pacientes me diziam assim 'Eu não quero morrer com esses remédios. Meus amigos estão morrendo.' Eles ficavam verdes de tomar aquele negócio. E morriam logo. Hoje eu sei com mais certeza ainda que muitos poderiam ter vivido mais tempo, até chegar o momento de usar uma coisa que não matasse, que o AZT era usado assim de tonelada e eles morriam rapidamente. [...] se um filho meu tivesse uma doença que o medicamento matasse antes da doença, eu não ia deixar ele tomar. E aí eles me procuravam porque eu não obrigava a tomar. E aífoi que eles me mandaram para o CRM, fiquei uns 7 anos nessa história, porque eu não dei o AZT. Eles não pararam nem quando foi proibido. Foi proibido usar o AZT naquele modelo. Você tem que usar uma dose dez vezes menor. [...] E isso provocava uma anemia profunda e eles morriam mais rapidamente. (E31)

Assim, começou a ser aplicada a terapia combinada, geralmente, associando duas drogas - AZT+ddI ou AZT+ddC.

A partir de 1994, com o financiamento do Banco Mundial, foram criadas diversas assessorias jurídicas nas ONGs, seguindo o modelo do Gapa. Foram essas assessorias e, em especial, a assessoria do Gapa, através da advogada Áurea Abbade, que, em 1996, iriam promover as ações de demanda de medicamentos para portadores de HIV/aids. (PROGRAMA NACIONAL DE DST E AIDS, 2005)

[...] quando começou a história da judicialização da saúde [...], era o Guedes o secretário, eu coordenava os Institutos de Pesquisa, o CRT era da minha coordenação. Então as ações judiciais para comprar esses medicamentos que não estavam no consenso, caiam todas na minha mesa. Evinham todos em sua maioria assinados pela Áurea $[\ldots]$... (E19) $)^{114}$

No governo Fernando Henrique Cardoso (FHC), ${ }^{115}$ em março de 1995, a Portaria n. 21 da Secretaria de Atenção à Saúde do Ministério da Saúde, garantiu a todos os pacientes o acesso à AZT, didanosina (ddI),

Entrevista concedida por E19, médico membro do Comitê de Vacinas do Programa Nacional de DST/Aids, em Salvador, em 13 de maio de 2011.

115 Foram Ministros da Saúde do governo FHC: Adib Jatene (janeiro/1995 a novembro/1996); José Carlos Seixas (novembro/1996 a dezembro/1996); Carlos César de Albuquerque (dezembro/1996 a março/1998); José Serra (abril/1998 a fevereiro/2002). 
pentamidina, ganciclovir, fluconazol e anfotericina B. Mas foi a partir de 1996, na terceira fase da história dos antirretrovirais, com os inibidores da protease, que de fato surgiram mais opções de tratamento, medicamentos que permitiram melhores desfechos clínicos e aumento significativo da sobrevida dos pacientes, uma verdadeira revolução no tratamento da aids. (SCHEFFER, 2008)

Enquanto a imprensa divulgava os avanços na terapia, ainda em 1995, começaram a acontecer as manifestações em espaços públicos, promovidas principalmente pelas ONGs/Aids, mas também por artistas, em iniciativas mais individuais, exigindo a distribuição de medicamentos pelo Estado. (PROGRAMA NACIONAL DE DST E AIDS, 2005)

Em Campinas/SP, no dia 14 de agosto de 1995, 40 manifestantes, entre portadores do HIV e familiares, ocuparam o paço municipal para reivindicar o coquetel. No dia 26 de setembro, inúmeras ONGs protestaram contra a falta dos novos medicamentos jogando litros de uma mistura que simulava sangue em frente às Secretarias Estadual e Municipal de Saúde de São Paulo. A avenida Paulista, em São Paulo, foi palco de grande ato no dia $1^{\circ}$ de dezembro do mesmo ano, com dezenas de corpos estendidos pelo chão.

Atos semelhantes pipocavam país afora e extrapolavam o âmbito dos grupos organizados. O estilista carioca Luiz de Freitas, por exemplo, colocou no final de seu desfile 15 portadores do HIV em protesto pelo preço e dificuldade de acesso aos medicamentos. Já o cenógrafo José Roberto de Godoy fez um protesto no Pavilhão da Bienal, em São Paulo. Nu, em meio a caixas de medicamentos, protestou contra a falta dos anti-retrovirais. (PROGRAMA NACIONAL DE DST E AIDS, 2005, p. 22-23)

Desde o surgimento do AZT, Betinho já defendia a garantia de tratamento pelo Estado aos portadores de HIV/aids. Apesar de não curar a aids, considerava que o AZT dava uma perspectiva de prolongamento da vida, e que era "um dever da sociedade brasileira dar ao aidético brasileiro essa chance" e teve papel preponderante na definição da política de acesso universal aos medicamentos antirretrovirais. (SOUZA, 1987) 
Com todos os avanços que se obtiveram no tratamento da aids, Betinho enviou duas cartas ao Presidente Fernando Henrique Cardoso, uma em janeiro e outra em fevereiro de $1996,{ }^{116}$ pedindo medidas mais efetivas. Em ambas, o presidente da Abia relatava suas críticas ao enfrentamento da epidemia no país, destacando a não consolidação do Programa Nacional, mesmo com o projeto do Banco Mundial, o alto custo de preservativos no país e a dificuldade para acesso aos medicamentos oferecidos pelo ministério, além do preço elevado dos medicamentos para aquisição pelos pacientes. Nos debates do seminário intitulado “Tratamento e Assistência em HIV/aids", promovido pela Abia, nos dias 25 e 26 de março de 1996, além dos avanços científicos, destacava-se a não prioridade do tratamento e da assistência no projeto do Banco Mundial, a dificuldade de acesso aos medicamentos oferecidos pelo Ministério da Saúde, a inexistência de uma política de medicamentos no país e Betinho criticou, duramente a periodicidade das campanhas, dizendo que "Para o governo, a epidemia é um festejo carnavalesco, como se fora do carnaval ninguém pegasse aids no Brasil”, ponto de vista crítico de esquerda sobre a política nacional. (CORRÊA, 1996, p. 7)

A apresentaçãonaXI Conferência Internacional de Aids de Vancouver, em julho de 1996, por David Ho e Martin Markowitz, dos resultados obtidos com um coquetel de três drogas, contendo um inibidor da protease, (BOUER, 1996, p. 16) associada à decisão favorável da Justiça de São Paulo à ação impetrada pela advogada do Gapa, Áurea Abbade, em nome da professora Nair Soares Brito para fornecimento dos medicamentos neodecapeptil, saquinavir e epivir pelo Estado, serviram de impulso para novas ações judiciais demandando fornecimento de inibidores da protease. (FELTRIN, 1996; MARTINS, 1996) Até aquele momento, a única cidade do país que fornecia por conta própria o coquetel era a cidade de Santos, no estado de São Paulo. (MARTINS, 1996)

A Folha de São Paulo do dia 13 de julho de 1996 trazia na sua sessão tendências/debates a questão "A importação de remédios contra a aids deve ser prioridade do Ministério da Saúde?”, para a qual havia três respostas,

Estas cartas foram publicadas no Boletim da Abia, n. 31, p. 15-16, jan./abr. 1996. 
que correspondiam aos argumentos dos grupos a favor, que consideravam um direito do portador de HIV/aids; daqueles que defendiam uma administração mais racional dos recursos; e dos que estavam contra a medida, que consideravam discriminar outras enfermidades:

a. A estratégia era defendida pelo médico infectologista David Everson Uip, que destacava que o custo médio elevado de $\mathrm{R} \$$ $1.000,00$ por paciente/mês, representava um investimento da ordem de $\mathrm{R} \$ 143$ milhões, mas justificados pelo aumento, qualidade e dignidade da sobrevida do paciente, bem como pela redução das hospitalizações e de outros medicamentos necessários, um ponto de vista clínico e individual;

b. A administração racional de recursos era expressa na fala de Luiz Roberto Barradas Barata. O médico sanitarista e secretário interino de saúde do estado de São Paulo no momento da reportagem, pontuava os critérios epidemiológicos como magnitude e transcendência da doença e a eficácia do tratamento como razões que justificavam a adoção da estratégia. Mas, na sua opinião, a realidade financeira da saúde pública não permitia um gasto da ordem de $\mathrm{R} \$$ 20.000,00 por paciente/ano, argumentos técnico-científicos;

c. E o médico, deputado federal pelo PSDB-SP e diretor-presidente da Blue Life Assistência Médica, Ayres da Cunha, argumentava contra a estratégia, considerando que a questão da aids era tratada de forma paternalista e que a distribuição gratuita de medicamentos para a aids seria uma medida discriminatória e ilegítima com os pacientes de outras patologias. Posição que podia estar representando os interesses da medicina supletiva pelos recursos do SUS.

Essas concepções aparecem na fala de alguns entrevistados, seja refletida na sua própria concepção ou no relato de posicionamentos com os quais não concordavam, porém, com maior abrangência, relacionada não apenas aos medicamentos, mas à toda a questão da assistência à saúde. Entre eles, a fala pareceu mais polarizada entre a justiça para os doentes e a discriminação contra outras doenças, não no sentido de negar o direito 
de acesso a medicamentos aos portadores de HIV/aids, mas de garantir o direito à assistência à saúde aos portadores de todas as enfermidades. Esse último argumento aparece principalmente na fala daqueles que saíram do espaço aids ou que transitaram por outros espaços do setor saúde. Outra posição destacada por um dos entrevistados era uma posição homofóbica.

[...] eu acho que isso é uma obrigação do Estado, [...] existia muitas posições contrárias, que isso era um absurdo num país onde você não tinha as questões mínimas de garantia de direitos, por que é que tinha que dar remédio pra pessoas promíscuas. Você ouvia isso de políticos. (E13)

[...] eu me lembro de médicos que também atendiam tuberculose e diziam: 'não, porque meus pacientes de tuberculose não tem remédios, porque só tem remédios para aids'. Não tem nada a ver uma coisa com a outra. (E18)

[...] Eu acho que a Política Nacional de Aids ela significa para o SUS um exemplo de como a gente deve trabalhar para as outras doenças. [...] Esse exemplo deveria ser pego, para a gente trabalhar com as outras, principalmente, com as negligenciadas. [...] eu acho que as outras tem que se igualar para que a gente possa ter um resultado parecido. (E11)

[...] para a política da aids, eu acho que o que o público em geral necessita éo quejá existe. É atendimento quando e onde eles precisam. Você não vêum indivíduo com HIV rodando por aídizendo que não foi atendido. Isso éuma coisa inédita. Porque você vê gente com lepra dizendo que não foi atendido. [...] Então para aids eu não sinto necessidade de mais do que já existe em termos operacionais. [...]. (E31)

Diante dessa diversidade de pontos de vista, cabe indagar porque prevaleceu aquele da universalização do tratamento.

O Programa Nacional foi considerado por alguns agentes como exemplo de que o SUS pode dar certo, ou seja, exemplo de política integral, universal, e inclusiva, que aproximou grupos minoritários como homossexuais, profissionais do sexo, usuários de drogas dos serviços de saúde. (Quadro 9) Mas pelo menos uma fala deixou claro que os usuários 
portadores de HIV/aids têm acesso a serviços especializados de saúde e suporte comunitário que não são acessíveis à qualquer pessoa. A excelência da assistência prestada pelos centros de referência estaria, segundo esse relato, restrita aos soropositivos, excluindo inclusive populações vulneráveis, evidenciando assim um enfoque no tratamento da doença e a secundarização da prevenção da aids, por um lado, e por outro, das limitações das demais políticas ou de outras políticas sociais, ou seja, a política nacional de controle da aids é vista como uma exceção.

[...] se você tem assim um problema de doença infectocontagiosa, você vai lá [Centro de Referência] e não pode ser atendido. Aí pergunta, você é positivo? Aí vocêfala, não sou. Já aconteceu duas vezes comigo. Porque são serviços de primei$r a$, porque tem infectologistas que em geral nos serviços não tem, aí você vai lá e vocênão épositivo. E por outro lado também eu encontrei pobres que se nãofossem positivos não seriam tão bem assistidos, como são tratados os pobres. Eisso vai desde serviços de saúde a associações comunitárias que dão suporte. Eu acompanhei uma ONG de usuários de drogas, 35 usuários de drogas em Osasco, ealgumas pessoas falavam: 'A sorte é que eu tive HIV. Porque agora eu tive esse suporte, tenho esse suporte comunitário'. Era população de rua, viviam nas ruas sem estrutura nenhuma, aíjá tinham casa, tinham moradia... (E25) ${ }^{117}$

Outro aspecto destacado pelos entrevistados foi a discussão da política com agentes dos diferentes subespaços sociais, em especial o espaço militante, ou seja, a sua importância como exemplo de possibilidade dos movimentos sociais interferirem numa política. Da mesma forma, na França, a luta pelo controle à epidemia da aids teve um cunho de contestação social, uma forma de expressão política, diferindo da representação de uma sociedade solidária, generosa e unida, observadas nos casos dos movimentos de luta contra outras doenças, como tuberculose e câncer, por exemplo, levando à organização de um movimento estruturado por associações militantes em defesa das pessoas atingidas e ameaçadas pela epidemia. (PINELL, 2010; PINELL et al., 2002) de maio de 2011. 


\begin{tabular}{|c|c|}
\hline Concepção & Trecho \\
\hline \multirow[t]{3}{*}{$\begin{array}{l}\text { Como modelo de política integral e } \\
\text { universal, estruturante do SUS e sem } \\
\text { discriminação }\end{array}$} & $\begin{array}{l}\text { A política da aids, ela significa que o SUS pode dar certo, porque a política da aids, ela } \\
\text { promove todas essas questões da equidade, da intersetorialiade, ela é universal, então } \\
\text { não tenha duvida de que ela é a prova de que o SUS dá certo. (E13) }\end{array}$ \\
\hline & $\begin{array}{l}\text { [...] Não tem nada de bom na aids. Mas o bom da aids foi que a aids mostrou um } \\
\text { SUS de altíssimo nível, com todos os princípios garantidos é possível, mesmo com } \\
\text { todos os problemas que a agente está falando aqui. Ele realizou o SUS de um jeito } \\
\text { interessante, tirou o véu da hipocrisia, da sexualidade escondida. Eu acho que ampliou } \\
\text { a generosidade pra com as pessoas homossexuais [...] Eu acho que é um bom exemplo. } \\
\text { Com toda suas limitações. (E32) }\end{array}$ \\
\hline & $\begin{array}{l}\text { [...] eu sempre digo que a aids talvez tenha sido a primeira experiência em que } \\
\text { a gente conseguiu concretizar os ideais do SUS. } 0 \text { acesso universal, a assistência } \\
\text { multiprofissional, integral e a participação da sociedade. Um envolvimento mesmo } \\
\text { visceral da sociedade, das pessoas afetadas. (E30) }\end{array}$ \\
\hline \multirow[t]{2}{*}{$\begin{array}{l}\text { Como exemplo da possibilidade dos } \\
\text { movimentos sociais interferirem numa } \\
\text { política }\end{array}$} & $\begin{array}{l}\text { A aids [...] é um dos maiores exemplos de aglutinação do movimento social. [...] Se } \\
\text { tu pegar, por exemplo, a organização dos diabéticos, a luta não é travada no campo } \\
\text { político. Ela é muito mais no campo da assistência, das condições de vida, a da aids não, } \\
\text { ela vem do campo político, porque ela perpassa as questões apenas da doença e entra } \\
\text { numa seara política, a partir do enfrentamento do preconceito, da discriminação, das } \\
\text { condições de vida, do direito do sujeito ser quem ele é, perpassa por tudo. E a partir } \\
\text { disso se faz a política, se faz um movimento político, se faz um enfrentamento com a } \\
\text { sociedade, com as instituições, com a igreja, com o estado, enfim. Então, a aids ela vai } \\
\text { mexer com todo o sistema de saúde. [...]ela vai forçar o sistema de saúde a ter uma } \\
\text { outra lógica. E ai a aids, ela ajuda na questão da formação do controle social. } 0 \text { que ela } \\
\text { provoca de ódio e de raiva é muito grande. Mas que ela contribui, ela contribui. (E12) }\end{array}$ \\
\hline & $\begin{array}{l}\text { [...] eu diria que o programa de aids, conforme ele se passou no Brasil, colaborou muito } \\
\text { para construção do SUS, do ponto de vista do controle social. Não esse controle social } \\
\text { que nós vemos dos conselhos, sabe. É lamentável, porque hoje em dia, nós vamos no } \\
\text { interior,[...] e são conselhos que na realidade são apêndice do poder executivo. [...] } \\
\text { eu acho que o programa de aids, ele teve sua missão importante enquanto programa } \\
\text { vertical, não tenha dúvida, porque isso ajudou muito a construir normas e implantar } \\
\text { procedimentos. Mas cada vez mais nós vemos como um processo horizontalizado que } \\
\text { faz parte da rede pública, mas tem que estar presente, como acontece com vários } \\
\text { programas, ou com várias abordagens. (E27) }\end{array}$ \\
\hline \multirow[t]{2}{*}{$\begin{array}{l}\text { Como exemplo de política inclusiva de } \\
\text { populações minoritárias e discriminadas } \\
\text { pelo SUS }\end{array}$} & $\begin{array}{l}\text { Sem dúvidas, eu acho que representa desafios, porque houve também, claro, de ser } \\
\text { adaptados, por exemplo, serviços especializados tiveram que ser criados, hospitais-dia } \\
\text { tiveram que ser criados. [...] atender e atender bem populações que estavam longe do } \\
\text { serviço de saúde. Atender à mulheres profissionais do sexo. Os profissionais de saúde } \\
\text { não estavam acostumados com isso. Discutir sexualidade com pessoas, fazer pré- } \\
\text { aconselhamento, pós-aconselhamento, eu acho que tudo isso foi um longo aprendizado } \\
\text { e, mesmo assim, eu acho que ainda há muitas resistências à atender pessoas que são } \\
\text { consideradas diferentes. Então, atender travestis não é algo trivial no SUS. (E16) }\end{array}$ \\
\hline & $\begin{array}{l}\text { [...] acho que o grande contributo da aids foi ter colocado na mesa as necessidades } \\
\text { de saúde de diferentes populações que se encontravam afetadas pela epidemia pra } \\
\text { dentro do contexto do sistema único de saúde, quer dizer, trazer os gays, trazer as } \\
\text { prostitutas, trazer usuários de drogas injetáveis pro contexto do sistema único de saúde } \\
\text { e colocar isso em evidencia, pautando ainda a questão da equidade, é extremamente } \\
\text { importante. (E17) }\end{array}$ \\
\hline
\end{tabular}

Fonte: Elaborado pela autora. 
Mesmo com as mudanças de governo e de ministros, Lair Guerra permaneceu na coordenação do Programa Nacional até 1996, quando sofreu um traumatismo craniano decorrente de um acidente de carro na volta de um congresso de aids realizado em Recife, momento em que o Programa Nacional foi assumido por Pedro Chequer, seu adjunto.

A relação do PN com a Abia, em especial com seu presidente, Betinho, mudou, seja em função da sua relação com o novo diretor, com quem tinha maior proximidade e disposições políticas semelhantes, seja devido aos avanços na política de aids no país.

Ele tinha uma birra com a Lair, havia uma querela entre ele e a Lair antiga. E comigo não tinha, porque ideologicamente nós tínhamos coisas em comum, ou quase tudo em comum. E no final, a gente se entendia muito bem. (E27)

O projeto de lei no 158/1996 (ANEXO B), de autoria do senador José Sarney, que propôs o acesso universal aos medicamentos para tratamento da aids, representava os anseios de diversos grupos, em especial da sociedade civil organizada, que já vinha promovendo mobilizações nesse sentido. Contudo, o projeto teria resultado de uma articulação entre o sociólogo Betinho, o médico sanitarista e deputado federal pelo Rio de Janeiro, Sérgio Arouca e o ex-ministro da saúde e ex-deputado Carlos Sant'Anna que à época era chefe de gabinete do senador José Sarney e teria escrito a minuta do projeto.

O Sarney, elefoi procurado pelo próprio Betinho. (E6)

Quem redigiu o projeto foi Carlos Sant'Anna, que era assessor do Sarney. (E9)

A ideia original foi de Sérgio Arouca, provavelmente conversando com Betinho. Porque Arouca era deputado pelo Rio. Aílevou, como se davam muito bem Arouca e Carlos, ele foi presidente da Fiocruz quando Carlos estava lá [no Ministério da Saúde] [...] Aí eles se conversavam, se apoiavam. Então quando chegou nessa lei, Carlos sabia escrever lei muito bem. [...] Todo mundo reconhecia isso. Então muitos deputados, e Arouca também foi lá, levavam para ele para ver a forma, o processo legislativo, aquele negócio todo. Edepois, a forma como caminhar no campo minado 
que éa Câmara para você chegar promulgar uma lei. A câmara e o senado, os dois. Então ele viu tudo e bolou com Carlos uma estratégia que disse assim: 'Se vocêdeixar Sarney apresentar provavelmente é mais forte.' Mas a ideia original foi de Arouca. E foi de Arouca trazido do Rio, que eu acho que foi Betinho. [...] Quem levou para Carlos a proposta, a ideia inicial foi Arouca, Carlos trabalhou na melhoria da proposta com Arouca [...] Então eu imagino que nesse desenho da estratégia para fazer com que o projeto de lei, chegasse a câmara, Carlos deve ter negociado com Arouca, que isso seria através de Sarney. Então Carlos entrou nisso no sentido de sensibilizar Sarney para fazer lá. Mas a ideia original foi essa. (E10)

A exposição de motivos do projeto de lei falava do direito constitucional à saúde e da questão humanitária, bem como das notícias da XI Conferência Nacional de Aids, realizada em Vancouver. A aprovação da contribuição provisória sobre a movimentação financeira (CPMF) era apresentada como um aporte orçamentário que poderia fazer frente a essa nova despesa, bem como ponderava acerca da possível redução de gastos com a assistência a doentes, relacionadas à infecções oportunistas e internações, e que o Brasil, como um país de grandes riquezas, não poderia deixar de garantir a esperança e condições de vida aos indivíduos acometidos pela pandemia da aids. (ANEXO B)

A tramitação do projeto no poder legislativo foi rápida: da apresentação do projeto à sua aprovação transcorreram 90 dias. Não houve polarização dos debates, todos os parlamentares que se manifestaram fizeram-no a favor do direito à saúde e da garantia de tratamento aos portadores de HIV/aids, haja vista que o projeto tratava de uma reafirmação dos direitos constitucionais, ainda que houvesse oposição de alguns deputados, como percebido na fala do deputado Ayres da Cunha ao jornal Folha de São Paulo. A votação da proposta na Câmara dos Deputados (PL n. 2.375 , 1996) foi adiada por requerimento do líder do governo, o deputado Benito Gama (PFL-BA), ainda que sob a discordância de alguns deputados como Fernando Gabeira (PV-RJ), Eraldo Trindade (PPB-AM), Alexandre Cardoso (PSB-RJ), Sérgio Miranda (PcdoB-MG), Matheus Schmidt (PDT-RS) e Paulo Rocha (PT-PA) que se opuseram à retirada da votação da pauta. A justificativa para o adiamento estava relacionada 
principalmente à alocação de recursos, uma vez que a despesa não estaria prevista, havendo necessidade de adequação do orçamento pelo governo federal. Nova votação aconteceu no dia 14 de outubro de 1996, apenas cinco dias depois. O relator, o deputado Arnaldo Farias de Sá (PTB-SP), propôs mudanças redacionais que foram revisadas no retorno ao Senado e incluiu a responsabilidade de todos os gestores do SUS (união, estados e municípios) no financiamento, assim como restrições socioeconômicas para a distribuição dos medicamentos e a priorização de pacientes em internação hospitalar. ${ }^{118}$ (AZEVEDO, 2010)

No retorno ao Senado, o relator, senador Lúcio Alcântara (PSDB$\mathrm{CE})$, manteve o texto original da PL 158 e rejeitou as restrições de caráter socioeconômico e a priorização de pacientes internados propostos pelo substitutivo da Câmara dos Deputados, considerando as restrições impostas inconstitucionais, haja vista a saúde tratar-se de um direito de todos e um dever do Estado, e que a tendência era de estímulo a políticas de desospitalização, não havendo recomendações na literatura médica de internamento para o uso de antirretrovirais. O cofinanciamento pelos gestores do SUS foi acatado, modificando o art. $2^{\circ}$ da PL 158. A redação final foi aprovada em plenário, correspondendo ao texto da Lei $n^{\circ}$ 9.313, sancionada em 13 de novembro de 1996 pelo presidente Fernando Henrique Cardoso. (AZEVEDO, 2010)

Ainda que de fato tenha apenas ratificado direitos constitucionais, a nova lei reforçou a luta dos portadores de HIV/aids e das ONGs/Aids pela garantia de acesso ao tratamento, levando inclusive a uma situação diferenciada do acesso aos medicamentos antirretrovirais em relação ao acesso a outros medicamentos no SUS, como já destacado anteriormente.

O passo seguinte foi o estabelecimento de protocolos para a prescrição dos medicamentos, a organização de fluxos e divisão de responsabilidades entre municípios, estados e união; à garantia do acesso aos medicamentos e à sustentabilidade da estratégia.

O parágrafo $3^{\circ}$ do substitutivo proposto pela Câmara dos Deputados (BRASIL, 1996a) dizia: "A distribuição gratuita dos medicamentos observará critérios sócio-econômicos, conforme regulamento, e dará prioridade aos pacientes em regime de internação hospitalar". 
Em dezembro de 1996, foi criado o Comitê Técnico Assessor para Terapia Antirretroviral que elaborou o guia de orientações terapêuticas em HIV/aids. Esse Comitê era composto pelos médicos Pedro Chequer (Dirigente do PN DST/Aids), Celso Ferreira Ramos (Prof. Doenças Infecciosas e Parasitárias UFRJ), Geraldo Duarte (USP - Ribeirão Preto), Heloísa Helena de Souza Marques (Médica pediatra do Hospital das Clínicas da USP), Helvécio Bueno (Assessor do PN DST/Aids), João Silva de Mendonça (Diretor do Serviço de Moléstias Infecciosas do Hospital do Servidor Público Municipal de São Paulo), Marinice Coutinho Midlej Joaquim (Técnica da Coordenação Materno-infantil), Norma de Paula Motta Rubini (Unirio), Rosana del Bianco (Chefe da Unidade de Assistência do Programa Nacional de DST/Aids), Sandra Maria Martin (Assessora da Unidade de Assistência à Saúde do Programa Nacional de DST/Aids) e Valdiléa Gonçalves Veloso dos Santos (Fiocruz). Em 1997, foi realizada a primeira revisão, tendo como produto o consenso para terapia antirretroviral para adultos e adolescentes infectados pelo HIV/aids.

A implantação da estratégia universal de acesso a antirretrovirais aumentou o registro de casos em torno de 39\% em 1996. Segundo declaração do Coordenador do Programa Nacional de DST/Aids, Pedro Chequer “[...] Muitos pacientes que se tratavam com médicos particulares e não notificavam a doença para as autoridades sanitárias tiveram de se identificar.” (FALCÃO, 1997, p. 6) Os mandatos judiciais que obrigavam o Estado a fornecer medicamentos fora das especificações e dos critérios estabelecidos no consenso terapêutico ampliavam o acesso, implicando em novos custos. (FALCÃO, 1997) Contudo, houve uma redução dos gastos com internação, em torno de 40\% no CRT de São Paulo e 35\% no Hospital Emílio Ribas, e no uso de medicamentos para infecções oportunistas, para o ganciclovir houve uma redução de $20 \%$. Um paciente em uso de antirretrovirais custava cerca de $\mathrm{R} \$ 10.000,00$ por ano, $50 \%$ menos que se ficasse doente. (MARTINS; TOSTA, 1997)

Um dos principais problemas para implantação doacessouniversal era a falta de controle logístico dos estoques de medicamentos - diversos pacientes pegavam medicamentos em diferentes unidades, desabastecendo a rede. (FALCÃO, 1997) Para organizar a distribuição dos medicamentos e 
acompanhar os resultados, Pedro Chequer, epidemiologista com experiência na elaboração de sistemas de informação em saúde, ${ }^{119}$ coordenou a elaboração de dois sistemas de informação para o Programa Nacional de DST/ Aids: o Sistema de Controle Logístico (Sisclom) e o Sistema Informatizado de Controle Laboratorial (Siscel). O Sisclom foi elaborado para controle na distribuição de medicamentos, permitindo uma visão global do percurso do medicamento até a sua distribuição e o controle do estoque, e o Siscel foi criado para acompanhamento dos exames laboratoriais. Uma outra iniciativa seria a implantação de um “cartão aids" para identificação dos portadores acompanhados no SUS, mas que não foi adiante devido à intenção do Ministério da Saúde de implantar o cartão SUS. ${ }^{120}$

O compromisso com a manutenção do acesso universal era assumido não apenas pelo Ministério da Saúde como pelo Palácio do Planalto. (SÃO NECESSÁRIOS..., 1997)

A aprovação da lei de acesso universal a medicamentos para portadores de HIV/aids impôs importantes transformações no espaço aids brasileiro: a crítica mais ácida das ONGs com relação à política quase que desapareceu, sendo a principal demanda o cumprimento do estabelecido na legislação, em especial o acesso a medicamentos; o Programa Nacional passou a ter uma posição dominante e reconhecimento internacional.

A luta pela sustentabilidade da estratégia de acesso universal aos antirretrovirais contribuiu também para a regulamentação dos medicamentos genéricos no país e influenciou o posicionamento político

Quando esteve no Centro Nacional de Epidemiologia (CENEPI), Pedro Chequer participou da criação do Sistema de Informação de Agravos de Notificação (Sinan).

120 "E em seguida nós bolamos o cartão, [...] eu tinha um exemplar desse cartão, era um cartão para paciente de aids. Porque mesmo com o Siclom posto e funcionando precariamente, começamos com pouco serviço, depois com mais 120 serviços, 150 serviços, hoje não sei quanto está, acho que está em 500, algo assim. Mas tínhamos um problema que surgia a partir do debate com o campo ou com as redes de pessoas vivendo, pacientes que moravam em São Paulo, por exemplo, que estavam na Bahia, como é que recebia o remédio? Ou se acabasse o remédio, ou se tivesse que permanecer? Ai nós bolamos um cartão, era um cartão que ia ter um chip que o paciente ia no Siclom, debitava na 'conta' dele. O Ministério ficou enciumado, a SAS era inimiga. Werneck, Dr. Werneck. Nós tínhamos o ministro que morreu, o gaúcho [Carlos César Albuquerque]. [...] Nós chegamos a ter o nosso cartão, em 1997, [...], o cartão aids. E lançamos oficialmente e tudo mais, mas aí foi vetado! 'Não... Vai ter o cartão SUS, o cartão SUS dá conta de tudo'. Tudo bem, infelizmente, estão patinando até hoje.”(E27) 
internacional do país haja vista a disputa com a indústria farmacêutica internacional pela redução dos preços dos medicamentos antirretrovirais. (LOYOLA, 2008) Essa foi umas das mais importantes disputas que aliou médicos sanitaristas, pesquisadores, agentes do campo burocrático e usuários contra a indústria farmacêutica.

Pedro Chequer saiu da direção do Programa Nacional em março de 2000 , quando foi convidado para ser representante do programa conjunto das Nações Unidas sobre HIV/aids (Unaids) no Cone Sul. Assumiu a direção do programa o médico Paulo Roberto Teixeira, primeiro coordenador do Programa Estadual de São Paulo, que permaneceu na função até 2003, quando foi para a Direção do Programa de Aids da OMS.

Foi durante a gestão de Paulo Teixeira que o Programa recebeu o prêmio Bill e Mellinda Gates, no valor de um milhão de dólares, considerado como a ação de saúde pública mais relevante de 2002. O prêmio foi investido em projetos de casas de apoio a portadores de HIV/aids. Foi também na sua gestão que na busca pela sustentabilidade do acesso a medicamentos antirretrovirais, foi proposta pela primeira vez pelo governo brasileiro a quebra de patentes. (ABBADE; BAIÃO, 2010)

A incorporação constante de novas tecnologias sempre implicou em aumento dos custos do tratamento para a aids. Entre o registro de um medicamento e a sua inclusão no consenso, ações judiciais eram movidas por pacientes que necessitavam da nova droga, obrigando o SUS a fornecer antirretrovirais não disponíveis na rede pública, às vezes medicamentos ainda sem registro no país. (SCHEFFER, 2008)

A sustentabilidade da estratégia de acesso universal passou a ser uma prioridade. O Ministro da Saúde José Serra decidiu centralizar e ampliar a produção nacional de antirretrovirais genéricos e ameaçou utilizar licenças compulsórias para produzir medicamentos patenteados. (NUNN, 2009) Laboratórios estatais como o Instituto de Tecnologia em Fármacos (Farmanguinhos) e Fundação para o Remédio Popular (Furp), de São Paulo, iniciaram a produção de antirretrovirais em 1999 e o Laboratório Farmacêutico do estado de Pernambuco (Lafep), em 2000. O início da produção nacional e as negociações com a indústria farmacêutica proporcionaram uma redução de $72,5 \%$ dos preços dos 
medicamentos antirretrovirais. Um comprimido de zalcitabina, que em 1996 custava 1,55 dólares passou a custar 0,08 dólares em 2000, produzida pelo Farmanguinhos. (FALCÃO, 2000)

Frente à política agressiva adotada pelo Brasil para a redução dos preços dos medicamentos para aids, em maio de 2000, os EUA abriram uma consulta na OMC junto ao governo brasileiro acerca do artigo $68 \mathrm{da}$ Lei 9.279/96 (Lei da Propriedade Industrial), que trata da licença compulsória de patentes, considerando que a mesma desrespeitava o acordo Agreement Trade-Related Aspects of Intellectual Property Rights (Trips). ${ }^{121}$ (WTO, 2000) Não satisfeitos com a resposta brasileira, os EUA entraram com uma queixa no Dispute Settlement Body ${ }^{122}$ (DSB) da OMC em janeiro de 2001 e chegaram a um acordo com o Brasil em 5 de junho de 2001, admitindo a possibilidade de quebra de patente em questões de saúde pública de países em desenvolvimento. (WTO, 2001a, 2001b)

A ação junto à OMC resultou de lobby da indústria farmacêutica norte-americana junto ao governo dos EUA em resposta ao congelamento de preços proposto pelo governo brasileiro, visando a redução de preços pelas indústrias detentoras das patentes, caso contrário seria usado o dispositivo da licença compulsória, prevista na Lei de propriedade industrial brasileira. (OLIVEIRA; MORENO, 2007) A solução foi a criação de um sistema de consultas bilateral: os EUA comprometeram-se a retirar a queixa, e o Brasil consultaria os EUA em caso de necessidade de uso do dispositivo da licença compulsória com relação a patentes de empresas daquele país. É interessante notar que, no acordo, os EUA pediam que o Brasil se comprometesse a não recorrer à OMC em relação às seções $204 \mathrm{e}$ 209 da Lei de patentes norte-americana, que se assemelhavam aos artigos 68 e 71 da Lei de Propriedade Industrial brasileira e que portanto tornavam sem efeito a queixa. (WTO, 2001a)

O recuo dos EUA constituiu-se importante vitória para o Brasil. Contudo, as discussões acerca da necessidade de revisão do acordo Trips

\footnotetext{
121 Acordo sobre os aspectos dos Direitos de Propriedade Intelectual relacionados ao comércio, entre os membros da OMC, que estabelecem padrões mínimos no âmbito do direito internacional relacionados às patentes, inclusive de medicamentos.

122 Órgão de Solução de Controvérsias.
} 
e da forma de lidar com as patentes nas questões de saúde pública, em especial para países em desenvolvimento, continuaram em fóruns multilaterais como a ONU.

Em 30 de outubro de 2001, foi realizada reunião entre o Unaids e parlamentares brasileiros em Brasília visando a criação de uma Frente Parlamentar de luta contra a aids, à qual se integraram os senadores Lúcio Alcântara (PSDB-CE) e Ricardo Santos (PSDB-ES), e os deputados Nelson Pellegrino (PT-BA), Fernando Gabeira (PT-RJ), Gilmar Machado (PT-MG), Esther Grossi (PT-RS), Laura Carneiro (PFL-RJ), Léo Alcântara (PSDB-CE), Maria Elvira (PMDB-MG), Marisa Serrano (PSDB-MS), Rita Camata (PMDB-ES), Marcos Rolim (PT-RS) e Agnelo Queiroz (PC do B-DF). (BRASIL, 2001a) O deputado Fernando Gabeira (PV-RJ) apresentou moção solicitando a solidariedade de todos os parlamentares do mundo à posição do Brasil de garantir medicamentos genéricos aos portadores de HIV. O pedido dava-se em razão da reunião da OMC no dia 9 de novembro, e da ameaça de países que queriam impedir a produção de genéricos no país. (BRANDÃO, 2001)

O Brasil estava liderando a negociação com a OMC desde setembro de 2001 para que o acordo Trips não fosse uma barreira para o acesso aos medicamentos e que estes fossem encarados como questão de Direitos Humanos. (UNAIDS, 2001) A Declaração sobre o acordo Trips e saúde pública foi assinada durante a Conferência Ministerial da OMC, entre $9 \mathrm{e}$ 14 de novembro de 2001, ${ }^{123} \mathrm{em}$ Doha, no Catar. (WTO, 2001c)

O resultado positivo sobre indicadores de morbi-mortalidade alcançado pela política de aids, com o acesso universal a medicamentos antirretrovirais, a partir de 1997, levou a um reconhecimento internacional da estratégia brasileira, com impacto importante sobre o financiamento internacional, que se deslocou para países com respostas menos estruturadas e quadro epidemiológico mais grave.

O Programa Nacional passou a assumir uma posição dominante no espaço aids nacional e a ser reconhecido no cenário internacional, todos os seus gestores permaneceram no espaço aids e assumiram posições

123 Para maiores esclarecimentos consultar Correa (2005). 
importantes em organismos internacionais, bem como diversos gestores municipais e/ou estaduais e técnicos do Ministério da Saúde, com maior destaque, assumiram posições no espaço aids internacional.

\section{Transformações no espaço aids: quem passou a se interessar pela aids e por quê?}

A resposta brasileira à epidemia da aids foi se tornando mais complexa ao longo dos 20 anos analisados no presente estudo. A estrutura do espaço aids brasileiro mostrou-se bastante dinâmica no referido período (19812001), com novos grupos de agentes sendo incorporados ao espaço militante a partir das mudanças observadas no comportamento epidemiológico da doença, assim como o estabelecimento de relações com agentes e instituições de outros espaços, como a indústria farmacêutica e organismos internacionais externos ao setor saúde como a Organização Mundial do Comércio, o que levou também a um maior envolvimento do campo político, com a criação da Frente Parlamentar de luta contra a aids em 2001.

Os entrevistados foram analisados de acordo com subespaço de pertencimento, volume de capital e sua relação inicial com o espaço aids também em 2001. (Quadro 10) Dos 33 entrevistados, 25 estavam no espaço aids em 2001, sendo 14 desde o período de 1983-1986. Dos 20 entrevistados que se inseriram no espaço até 1986 (Quadro 3), sete afastaram-se do espaço aids até 2001: E7, E8, E10, E11, E24, E29 e E31. Outros entrevistados, como E2 e E5, que entraram nesse espaço mais tarde, também se afastaram posteriormente. As saídas do espaço aids muito revelam de sua natureza de espaço de lutas e conflitos de ordem política, burocrática e geracional, envolvendo paixões (illusio). 
QUADRO 10 - Agentes participantes e fundadores do espaço aids segundo subespaço de pertencimento, graduação, profissão dos pais, volume de capital científico, burocrático, político e militante e relação com a aids, em 2001

\begin{tabular}{|c|c|c|c|c|c|c|c|c|c|}
\hline E & Graduação (ano) & SE & Prof. Pai & $\begin{array}{l}\text { Capital } \\
\text { cultural } \\
\text { (Escolar) }\end{array}$ & CC & $C B$ & $C P$ & $\mathrm{CM}$ & Relação com a aids ${ }^{1}$ \\
\hline 15 & Turismo (S/I) & \multirow{9}{*}{ 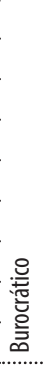 } & Policial civil & $S$ & - & $P$ & - & - & Profissional \\
\hline 30 & Medicina (1985) & & Contador & PGS & - & $A$ & - & - & Profissional \\
\hline 17 & Sociologia (S/I) & & $S / I$ & PGL & - & $A$ & B & - & Profissional \\
\hline 23 & Medicina (1989) & & Eletrotécnico & $S$ & - & $A$ & - & - & Profissional \\
\hline 28 & Proc. De dados (S/I) & & Médico pediatra & PGL & - & $A$ & - & - & Profissional \\
\hline 21 & Economia (após 2001) & & Marceneiro & $S$ & - & $A$ & - & - & Profissional \\
\hline 1 & Ciências Sociais (1992) & & Empresário & $P G L$ & - & $A$ & - & - & Profissional \\
\hline 26 & Medicina (1973) & & Contador & $P G L$ & - & $A A$ & - & $B$ & Profissional \\
\hline 27 & Medicina (1977) & & Comerciante & 5 & - & $A A$ & B & - & Profissional \\
\hline 28 & Hotelaria (1994) & \multirow[b]{10}{*}{ 营 } & Agricultor & $S$ & - & - & - & $M$ & Pessoal \\
\hline 22 & Psicologia (1991) & & Representante lab. farm. & $S$ & - & - & - & $M$ & Pessoal \\
\hline 5 & Ciências Sociais (1988) & & Militar & PGS & $B$ & $A$ & - & M & Profissional \\
\hline 33 & Psicologia (1985) & & Militar & PGS & $B$ & - & B & $M$ & Pessoal \\
\hline 14 & Administração (após 2001) & & Comerciante & $E M$ & - & - & - & A & Pessoal \\
\hline 6 & Filosofia $(S / I)$ & & Político & $S$ & - & - & - & A & Pessoal \\
\hline 12 & Administração (após 2001) & & Vendedor & $E M$ & - & $M$ & - & A & Pessoal \\
\hline 18 & Matemática (1972) & & Contador & PGS & $M$ & - & B & A & Pessoal \\
\hline 20 & Ciências Sociais (1968) & & Fazendeiro & PGS & $M$ & - & B & A & Pessoal \\
\hline 3 & Direito (S/I) & & $*$ & $S$ & - & - & B & A & $\begin{array}{l}\text { Profissional/ } \\
\text { Pessoal }\end{array}$ \\
\hline 19 & Medicina (1961) & \multirow{6}{*}{ 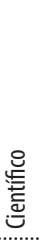 } & Comerciante & PGS & $B$ & $A$ & B & - & Profissional \\
\hline 25 & Ciências sociais (1987) & & Comerciante & $P G S$ & B & - & - & - & Pessoal \\
\hline 16 & Medicina (1981) & & Médico, professor & PGS & $M$ & $M$ & - & - & Profissional \\
\hline 32 & Psicologia (1977) & & Político & PGS & $M$ & - & - & $B$ & Profissional \\
\hline 4 & Medicina (1969) & & Professor & $P G S$ & $A$ & $B$ & B & $B$ & Profissional \\
\hline 9 & Medicina (1965) & & Telegrafista & PGS & $A A$ & $A$ & - & - & Profissional \\
\hline
\end{tabular}

Fonte: Elaborado pela autora.

Notas:*Pai falecido quando a entrevistada tinha apenas 2 meses, avô paterno mascate, avô materno fabricante de vinhos. / CC: capital científico; CB: capital burocrático; CP: capital político; CM: capital militante; S/I: sem informação; S: superior; EM: ensino médio; PGS: pós-graduação strito senso; PGL: pós-graduação lato senso, B: baixo; M: médio; A: alto; AA: muito alto.

(1) O Apêndice Capresenta as falas dos entrevistados que resultaram na classificação apresentada no Quadro 13. 
O afastamento dos agentes do espaço aids esteve relacionado (Quadro 11):

- A motivos pessoais, como a perda de parentes e amigos, vítimas da epidemia, no caso de E8;

- A questões profissionais como:

- problemas de relacionamento (brigas, desentendimentos ou não adaptação a novas gestões) no trabalho, como nos casos de E7, E29,E23 e E5;

- incompatibilidade ou limitação do trabalho relacionado à aids em relação aos anseios profissionais, como nos casos de E2 e de E11, para os quais a aproximação com a aids ocorreu pela vinculação, respectivamente, à área de planejamento e com a Divisão Nacional de Dermatologia Sanitária. E2 não queria limitar a sua atuação a uma política de saúde específica e também pretendia ter sua inserção prioritária no campo científico. E11 tinha por opção profissional a dermatologia e o trabalho com hanseníase, com a separação das duas áreas, optou por atuar no Programa de Hanseníase, no qual chegou a ser dirigente do programa; e, até mesmo, o sucesso da política, como no caso de E31, também presente na fala de E11.

Os agentes do subespaço burocrático foram os que apresentaram menor capital cultural, geralmente, nível superior ou pós-graduação lato senso. A exceção foi a médica E30, que à época era coordenadora do Programa Estadual de DST/Aids do Estado do Rio de Janeiro, tendo assumido anteriormente a chefia da Unidade de Assistência do PN DST/ Aids entre 1997 e 2000. E30 desde 2006 assumiu a diretoria do Instituto de Pesquisa Clínica Evandro Chagas e em 2008 concluiu o doutorado em Saúde Pública, participando a partir de então do subespaço científico.

A relação com a aids no momento de engajamento no subespaço burocrático, deu-se, como no período de 1983-1986, por questões profissionais e os agentes concentravam principalmente, e quase exclusivamente, capital burocrático. Apenas E26, E27 e E17 apresentaram pequeno volume 


\begin{tabular}{|c|c|c|}
\hline Agente & $\begin{array}{l}\text { Subespaço no momento } \\
\text { do afastamento }\end{array}$ & Evidências \\
\hline E2 & Burocrático & $\begin{array}{l}\text { "[...] Eu me lembro de que uma vez alguém comentou comigo,'você que tem essa habilidade } \\
\text { no planejamento, você podia utilizar isso para ser uma consultora'e essa coisa de carreira } \\
\text { internacional, mas eu acho isso uma bobagem. Eu não tenho interesse, eu não tenho, nesse } \\
\text { sentido não [...] eu não teria vontade de trabalhar com uma política mais específica assim na } \\
\text { minha vida profissional." }\end{array}$ \\
\hline E5 & Burocrático & $\begin{array}{l}\text { "[...] eu queria sair daquele ritmo enlouquecido que eu estava no Ministério ainda que eu } \\
\text { pudesse fazer consultorias para o Ministério mais pontuais, [...] E depois realmente o ritmo } \\
\text { do trabalho mudou, [...] Então a ONG aqui de São Paulo acha que o projeto dela não está bom } \\
\text { não sei porquê, mandava e-mail para o XXXX, o XXXX respondia, a ONG do Rio mandava para o } \\
\text { XXXX, o XXXX respondia, então a chefe da unidade não serve para nada, porque eles resolvem } \\
\text { do jeito que querem depois você fica sem saber, [...] ele nem se tocava que eles passavam por } \\
\text { cima. XXXX nunca fez isso. Chegava uma correspondência para ele reclamando de tal projeto, } \\
\text { ele respondia com copia para mim - estou encaminhando para a chefe da unidade - então, } \\
\text { isso te empodera, porque diz a autoridade que você tem [....." }\end{array}$ \\
\hline E7 & Burocrático & $\begin{array}{l}\text { "...] hoje eu nem sei mais quase nada de aids, desencantei, sai daquela coisa, que é uma } \\
\text { politicagem que eu não aguentei. Não faz bem pra minha saúde mental. Agora, não, agora que } \\
\text { virou doença de pobre, né? Mas na época, era muito virulento... Nossa! [...] foi uma decisão } \\
\text { minha, mas eles começaram a me boicotar. [...] eles foram me solapando e ai eu dei uma } \\
\text { entrevista que a campanha do carnaval não saiu porque não autorizaram a tempo [...] aí ele me } \\
\text { chamou lá, me tirou, disse que iam trazer XXXX de volta porque fazia parte lá do grupo dele. } \\
\text { Porque XXXX, ele tinha muitas conexões entre os sanitaristas brasileiros, um monte de coisa } \\
\text { lá. [...] Eu ainda fiz algumas coisas, tentei algumas coisas, mas ai tudo que eu fosse tentar, } \\
\text { eu ia ser podado, [...] fui aos poucos mudando. Não é fácil não. [...] eu me interesso até hoje, } \\
\text { eu tenho uma visão... acompanho um pouco, mas ai, profissionalmente, você começa a fazer } \\
\text { pesquisa em outras áreas, aí você começa a ser absorvido." }\end{array}$ \\
\hline E8 & Militante & $\begin{array}{l}\text { "Daí, o meu irmão teve aids. E morreu. E sabe, eu lá, militante, uma das pessoas que mais falava } \\
\text { sobre o assunto, não sei o que, eu não soube reconhecer quando ele estava com aids. [...] Daí } \\
\text { fiquei completamente desgostoso com o tema, com as pessoas, comigo mesmo, com tudo. [...] } \\
\text { e não quis mais lidar muito com esse tema de homossexualidade, o tema da aids. E aí eu já } \\
\text { estava desgostoso com essa briga do Somos e todas essas coisas." }\end{array}$ \\
\hline E11 & Burocrático & $\begin{array}{l}\text { "[...] } 0 \text { Programa de Aids foi para um canto e o programa de hanseníase ficou em outro canto. } \\
\text { E aí nessa divisão foi que eu sai do Programa de Aids. Eu preferi, porque eu sou dermatologista } \\
\text { e minha formação é em hanseníase, e aí eu fiquei na hanseníase. E aí só voltei para a aids no } \\
\text { ano de 2004." }\end{array}$ \\
\hline E23 & Burocrático & $\begin{array}{l}\text { "[...] foi uma forma de proteção pra mim. Se eu continuasse vivendo, acompanhando o } \\
\text { movimento, eu ia sofrer. Então eu preferi realmente apagar, 'é página virada, apagada do meu } \\
\text { folhetim.." }\end{array}$ \\
\hline E29 & Militante & $\begin{array}{l}\text { "Eu já queria sair, eu sentia que já tinha cumprido um ciclo, mas a saída em si foi meio } \\
\text { traumática, porque houve uma briga lá, não foi muito boa..." }\end{array}$ \\
\hline E31 & Científico & $\begin{array}{l}\text { "Eu me retirei por uma razão só [...] Porque eu acho que funciona muito bem no sistema. } \\
\text { Porque você tem jovenzinhos nos postos de saúde que são muito mais bem informados do que } \\
\text { eu, que vão aos congressos animadamente, que acompanham tudo, que eu não tenho mais } \\
\text { paciência para acompanhar. Que disputam espaços e tudo isso e eles fazem isso com muito } \\
\text { mais habilidade. [...]" }\end{array}$ \\
\hline
\end{tabular}

Fonte: Elaborado pela autora.

Nota: XXXX - supressão de nomes de indivíduos citados. 
de capital militante e político, respectivamente. Os demais agentes do subespaço burocrático não possuíam qualquer engajamento político ou militante. É interessante notar, contudo, que diversos dos agentes desse subespaço gozam de grande reconhecimento (capital simbólico) ao interior dos diferentes subespaços do espaço aids, como E26 e E27, por exemplo. (Quadro 10) Talvez a possessão de um capital (burocrático) garantido pelo Estado, que corresponde a um meta capital, lhes tenha garantido poder sobre outros tipos de capital, ou seja, para além do capital garantido pelos títulos ou diplomas, os agentes do Estado possuem o poder de nomeação, delegado pelo Estado, quer dizer, possuem um capital que dá poder sobre outras espécies de capital e, portanto, sobre outros campos no sentido de Bourdieu (2012). Por exemplo, o Programa Nacional, define quem são os experts nacionais em medicamentos antirretrovirais, quando indica ou nomeia quem vai participar do comitê específico para esse fim.

O subespaço militante continuou atraindo principalmente agentes que tinham uma relação pessoal com a aids - pessoas vivendo com HIV/ aids, grupos com maior risco para adquirir a doença, amigos e familiares. Entre os que ingressaram após 1986, apenas E5 teve uma aproximação profissional. Os novos agentes possuíam, em 2001, menor capital cultural que aquele apresentado pelos militantes que ingressaram no espaço aids no período entre 1983-1986: se os mais antigos possuíam, quase todos, pós-graduação (mestrado ou doutorado), a única exceção era a advogada E3, entre os seis mais novos predominava curso superior completo (50\%), seguido do ensino médio (33,3\%), apenas um (1,7\%) agente possuindo pós-graduação (doutorado). Entre os militantes, E5 e E12 possuíam um volume alto e médio, respectivamente, de capital burocrático. Em 2001, E5 assumiu a Unidade de Articulação com a Sociedade Civil e Direitos Humanos do PN de DST/Aids, de 1992, até aquele momento seu engajamento era no espaço militante. (Quadro 10) Contudo, após a sua inserção no Ministério da Saúde, não considerava o retorno à(ao) militância/ativismo uma opção.

[...] apesar do tempo que eu fiquei no programa e de eu achar que conseguia esse distanciamento com o movimento, principalmente com o Pela Vidda, [...] mas 
quando eu saí do programa eu tinha certeza que eu não queria voltar para ONG, para mim não tinha nada a ver profissionalmente, por outro lado o fato de eu ter sido do governo também não me deixou à vontade no primeiro momento que eu fosse virar ativista de novo, no sentido pleno do termo [... ]. (E5 $)^{124}$

E12 também teve uma experiência na gestão, na Secretaria Municipal de Porto Alegre e inclusive defende que os gestores da política de HIV/ aids deveriam ser pessoas vivendo com HIV/aids.

[...] isso faz o diferencial. Na medida que eu estou aqui trabalhando, eu sei que nesse exato momento tem um monte de gente no hospital de clínicas, na emergência, com infecção oportunista, com diagnóstico tardio. O problema é que eu fico pensando isso todo o tempo. Eu não enxergo isso como um problema do outro apenas. Eu enxergo isso como um problema de quem vive com isso e quem pode a qualquer momento estar lá junto. Então eu sei da emergência disso. Eu sei muito mais da emergência disso, como uma mulher que na saúde da mulher sabe a emergência da questão da discussão do aborto. Para um homem pode até passar batido, mas para uma mulher essa discussão éfundamental. (E12)

Esse é um ponto de vista relacionado às disputas entre soropositivos e outros militantes no momento de criação da rede de pessoas vivendo com HIV/aids e mesmo anterior a esse período, quando foram criadas as primeiras ONGs de pessoas vivendo com HIV/aids.

[...] teve uma briga muito grande exatamente assim dessa coisa das ONGs que não representavam os soropositivos e que faziam dos soropositivos a estrada do assistencialismo absoluto. Então as pessoas ia lá só para receber e não participavam das decisões e nem da constituição. Então teve uma briga de um grupo de pessoas que viviam com HIV/aids com as instituições que estavam constituídas, exatamente para discussão de qual é o espaço de quem e o que fazemos aqui. Eu acho que isso era anterior até a constituição da rede e essa discussão ela foi se ampliando. Quando entrei para o movimento, logo na sequência, teve um encontro nacional em São Paulo e essa discussão ali se aprofundou, da 'ONG, que bicho é esse?', que

Entrevista concedida por E5, socióloga, diretora do Grupo Pela Vidda-RJ, em São Paulo, em 4 de maio de 2011. 
era o lema, então começou uma discussão muito forte exatamente para ver qual o lugar que esse soropositivo iria ocupar, e qual era a legitimidade das ONGs que estavam atéali instituídas. A princípio a rede acho que ela foi formada exatamente para poder ter o protagonismo de quem vivia com HIV/aids, de uma forma diferenciada. Houve uma ruptura entre essas pessoas e as ONGs mesmo que nessas outras ONGs tivessem pessoas soropositivas. O Gapa São Paulo é um exemplo disso. Paulo Bonfim que era o presidente, era pessoa vivendo com HIV/aids, mas a forma de trabalho nas ONGS é que estava sendo questionada. (E6)

Apenas dois dos entrevistados (E25 e E16) foram agentes do subespaço científico que entraram depois de 1986 no espaço aids. E25 iniciou sua relação com o espaço aids a partir de questões profissionais e E16 como objeto de pesquisa de sua dissertação de mestrado. Os agentes desse subespaço, em 2001, foram os que apresentaram uma maior diversidade de capitais. E4 possuía alto capital científico e pequeno volume de capital burocrático, político e militante, sendo o único agente que apresentava todos os tipos de capital estudados. A principal combinação foi o acúmulo de capital científico, específico do subespaço em questão, e capital burocrático, resultado da participação desses agentes (E19, E16, E4 e E9) em posições nas Secretarias Estaduais ou no Ministério da Saúde, em funções relacionadas ou não à aids, ou na burocracia universitária, em alguns momentos, ou de institutos de pesquisa/laboratórios. (Quadro 10)

Foi bastante frequente o trânsito de agentes do subespaço militante para o subespaço burocrático. Os militantes entrevistados que chegaram ao campo burocrático, em sua maioria, engajaram-se no espaço aids por motivo pessoal e referiram que essa era uma posição em que eles poderiam atuar de forma mais concreta, fazer mais, ir além da crítica política, o que na opinião de alguns inclusive tornava a sua atuação nesse subespaço ainda mais gratificante, como fica claro na fala de um dos entrevistados:

Você se sente realizado por ter militado na área de aids?

- Com certeza.

E trabalhando com aids? 
- Mais ainda. [...] Porque na militância, tu provoca, tu provoca, mas tu não faz.

Aqui eu posso fazer. (E12)

Entrevistados como E6 e E13 ainda não estavam no subespaço burocrático em 2001, mas quando foram entrevistados compunham o quadro do Departamento Nacional de DST/Aids e Hepatites Virais.

O mais frequente na história do programa/departamento sempre foi que um médico ocupasse a direção. As únicas exceções foram a sua primeira gestora, que era biomédica, e entre 2003 e 2004 o sociólogo Alexandre Grangeiro. Todos os outros gestores eram médicos: Pedro Chequer, Paulo Roberto Teixeira, Mariângela Simão, Dirceu Greco e Fábio Mesquita. O campo médico exerceu, e ainda exerce, papel dominante no espaço de forma que uma entrevistada chegou a afirmar que ser médico era um dos critérios para assumir a direção do programa/departamento.

Depois de participar da gestão da política e vivenciar os limites e possibilidades da gestão, de ter se tornado um agente do Estado, geralmente os militantes permaneciam no subespaço burocrático, faziam uma trajetória ao interior desse subespaço nos diferentes níveis de gestão do SUS, sendo contratados através de projetos viabilizados pelos acordos de empréstimo ou assumindo cargos de confiança, tornando-se o que Goulart (2006) denominou de "executivos da saúde". Contudo, devese destacar que há exemplos de agentes do espaço militante que, mesmo tendo assumido funções no campo burocrático, depois retornaram a esse espaço, como, por exemplo, Paulo Bonfim do Gapa que assumiu a coordenação do Programa Municipal de DST/Aids de São Paulo entre 1989 e 1991, e no retorno ao Gapa, assumiu a presidência da entidade (ABBADE; BAIÃO, 2010), o que pode ser explicado pela diversidade de trajetórias dos agentes analisados. Ao assumirem posições na gestão da política de aids, esses agentes adotaram uma postura empreendedora, buscando promover inovações, principalmente devido ao seu envolvimento emocional com a causa em questão, congregando dedicação, criatividade e iniciativa à sua atuação, o que caracterizaria o empreendedorismo militante. (GOULART, 2002) Esses agentes fizeram uma conversão do seu capital militante em burocrático, adaptando para o campo burocrático o 
conjunto de saberes e práticas adquiridos nas mobilizações, nas lutas e na atuação no movimento associativo sob a forma de técnicas, de disposições de agir, intervir ou simplesmente obedecer.

Outro aspecto importante referido por todos os entrevistados é a satisfação de ter participado da construção da resposta brasileira à epidemia da aids. Quando questionados acerca da realização profissional, alguns referiram que preferiam não se sentir realizados, para continuar indignando-se, mas de uma forma geral, aparecem sentimentos como engajamento e orgulho de ter contribuído para a elaboração de uma política reconhecida internacionalmente pelos seus resultados, ainda que esteja presente nas falas também a necessidade de continuar lutando pela manutenção e sustentabilidade das conquistas. (APÊNDICE I) Alguns agentes do subespaço científico (E9, E19, E30) também transitaram pelo espaço burocrático, mas esses ou não se desvincularam em nenhum momento de seu espaço de origem, atuando em dois subespaços (científico ou burocrático), ou retornaram ao seu espaço de origem após um período na gestão.

No campo burocrático, predominaram os médicos desde o início da configuração do espaço, em especial os dermatologistas sanitários e médicos sanitaristas. Alguns clínicos docentes de escolas médicas de renome e referências nacionais na área das doenças ditas "tropicais", como Ricardo Veronesi e Vicente Amato Neto, contribuíram para a elaboração do discurso oficial, participando de reuniões e da Cnaids. Eduardo Côrtes foi o único médico clínico a assumir a direção do programa no período analisado, mas a participação de médicos clínicos no campo burocrático aumentou à medida que foram surgindo possibilidades terapêuticas. Essa participação tornou-se mais evidente principalmente a partir da descoberta do coquetel, na maioria das vezes através da participação em comissões e comitês específicos. Progressivamente o quadro técnico do programa incorporou agentes com diferentes formações, inclusive com a contratação do pessoal oriundo dos movimentos sociais, aumentando significativamente o número de funcionários desde a sua criação até os dias de hoje, já sendo o Departamento de DST, Aids e hepatites virais, desde 2009, o departamento contava, em 2011, com aproximadamente 240 funcionários. 



\section{5 \\ Conclusões e considerações finais}

O espaço aids brasileiro constituiu-se historicamente como um espaço de luta pela organização da resposta à epidemia e de intervenção sanitária, na qual o que está em disputa é a autoridade de falar sobre o significado da doença, suas formas de prevenção e tratamento, bem como sobre as estratégias mais adequadas para o seu controle. Sua conformação iniciou-se com a emergência da resposta governamental no estado de São Paulo, envolvendo agentes do campo médico e do espaço da saúde coletiva (médicos clínicos docentes e pesquisadores de grandes hospitais-escola - dermatologistase infectologistas - e sanitaristas), do campo burocrático, do movimento homossexual e do campo científico. A esses juntaram-se, ao longo do processo de conformação do espaço aids, movimentos de hemofílicos, talassêmicos e profissionais do sexo, e, mais tarde, as ONGs/aids - em especial Gapa, Abia, Pela Vidda, GIV e RNP+-, como são conhecidas as associações específicas de luta contra a aids no Brasil, que compunham o subespaço militante. Trata-se de um espaço de complexas relações, influenciado pelos campos político, religioso e jurídico.

A política de controle da aids no Brasil teve início em 1983, no estado de São Paulo, antes mesmo de haver uma resposta terapêutica médica eficaz, com clara dominância de agentes do campo médico, com inserção no campo burocrático e no espaço da saúde coletiva. A política surgiu de uma demanda de um grupo de representantes do movimento homossexual à Secretaria de Saúde do Estado. O movimento homossexual, que inicialmente negava a doença, foi sensibilizado pelas notícias trazidas por pessoas que viajavam ao exterior, pela divulgação através da mídia em 1983 do diagnóstico dos primeiros casos brasileiros e pela reunião sobre a doença com o médico infectologista e professor da USP, Ricardo Veronesi. Esse grupo de representantes do movimento homossexual, composto por 
artistas, docentes, pesquisadores, jornalistas, publicitários, entre outros, além de alto capital cultural, também possuía uma rede de contatos importantes, um capital social que permitiu ser agendada uma audiência com o Secretário de Saúde do Estado para demandar uma atuação específica do poder público.

Pode-se destacar como condições históricas de possibilidade para a emergência precoce dessa política em São Paulo, em um momento que ainda não havia evidências de sua magnitude e vulnerabilidade:

- A existência de um movimento homossexual organizado, com contatos internacionais e com lideranças que ocupavam posições de destaque, com elevado capital econômico e social;

- A organização do sistema de saúde no estado de São Paulo, inclusive com a criação da carreira de sanitarista, resultante da reforma administrativa do final da década de 1960, Reforma Leser;

- O caráter democrático e modernizador do governo Montoro e em particular do secretário de saúde João Yunes, professor da Faculdade de Saúde Pública da Universidade de São Paulo e militante do movimento da reforma sanitária;

- A concomitância deste processo com o próprio movimento sanitário, permitindo a incorporação de seus pressupostos na formulação das estratégias de controle da epidemia.

Somaram-se a essas condições o fato de que a Divisão Estadual de Dermatologia Sanitária, naquele momento, tinha um grupo de trabalho para a organização de um programa de doenças sexualmente transmissíveis constituído, no qual o coordenador dessa divisão e do grupo de trabalho era um médico, sanitarista e ex-militante do grupo Somos.

A resposta nacional, contudo, iniciou-se apenas em 1985, após estados como São Paulo, Rio de Janeiro e Rio Grande do Sul já terem organizado programas de saúde específicos para combater a epidemia. No âmbito nacional, podem ser consideradas como condições para a decisãoda inclusão da aids na agenda política: 
- O processo de transição democrática;

- A chegada de sanitaristas a cargos de chefia no Ministério da Saúde;

- A rápida evolução da epidemia;

- A existência de grupos de pesquisa em doenças infecciosas e parasitárias, envolvendo particularmente patologistas que se converteram em imunologistas;

- Os avanços no campo médico sobre a doença e o estágio de desenvolvimento da pesquisa clínica e laboratorial sobre o HIV/aids;

- A organização por parte de alguns estados de programas de aids;

- A pressão exercida pelos movimentos sociais e pela própria imprensa.

Pelo pioneirismo, os agentes do estado de São Paulo sempre foram dominantes no espaço aids no Brasil, seja no subespaço científico, no subespaço burocrático, ou no espaço militante - grupos homossexuais, ONG-Aids. Ainda que apenas em 2000, a gestão do Programa Nacional tenha sido assumida por um paulista, a orientação técnica e política do Programa Nacional seguiu o referencial do Programa de Aids do estado de São Paulo e os agentes paulistas apresentavam elevado capital simbólico.

Os agentes que se engajaram no espaço aids brasileiro eram pessoas afetadas pela epidemia, ou seja, pessoas vivendo com HIV/aids, pessoas vulneráveis à aids, como homossexuais, usuários de drogas injetáveis, hemofílicos, profissionais do sexo, seus parentes e amigos; ou profissionais, médicos e pesquisadores, principalmente. Aqueles que entraram nesse espaço de luta por questões de ordem pessoal, geralmente, assumiram posições no subespaço militante, possuíam formação diversificada e um capital cultural importante, quase todos possuindo pós-graduação stricto senso (mestrado ou doutorado) no período de 1983-1986, característica que não é mantida pelos ingressantes após esse período, que em 2001 possuíam menor capital cultural, predominando curso superior completo, seguido do ensino médio. Nos subespaços burocrático e científico, o predomínio era de graduados em medicina, sendo que os agentes do 
campo científico possuíam pós-graduação stricto senso ou estavam realizando o curso.

É interessante notar que, ao contrário do que aconteceu na França, onde as associações específicas de luta contra a aids surgiram frente à demora do Estado em responder a uma nova epidemia, no Brasil elas surgiram após implantação da política governamental, inclusive da política nacional, e foi fomentada pelo Estado, no sentido em que esse foi o primeiro financiador dessas associações. Esse incentivo do Estado na constituição das ONGs/aids não foi exclusivo do Gapa-SP, que teve apoio da SES-SP inclusive cedendo uma sala no seu prédio e apoio logístico, mas também a Abia teve seus primeiros financiamentos garantidos pelo Inamps e pela Finep, instituições estatais, através de militantes da reforma sanitária, como Hésio Cordeiro e Reinaldo Guimarães que assumiam posições importantes nesses órgãos.

Excluída essa diferença, são muitas as semelhanças entre os movimentos associativos francês e brasileiro: ambos são constituídos por agentes com histórico de militância de esquerda - na França a militância de esquerda de 1968; no Brasil, no movimento pela redemocratização, participando de partidos clandestinos, como PCB e PCdoB, da construção do PT e do movimento das comunidades eclesiais de base; nos dois países, os militantes buscavam uma exterioridade ao movimento homossexual, ainda que muitos de seus integrantes fossem homossexuais e mesmo oriundos desse movimento. No Brasil, assim como na França, inicialmente as associações surgiram para preencher os vazios e as lacunas deixadas pela insuficiência da política estatal, que, aqui no Brasil, representam as ONGs de caráter político-assistencial, como o Gapa. Mais tarde surgiram associações de cunho eminentemente político, que criticavam o Estado, mas que também se opunham ao reformismo das associações já estabelecidas, como a Abia no caso brasileiro - e sua crítica ao Gapa.

As disputas ao interior de cada subespaço deram-se no campo médico entre dermatologistas, infectologistas e os especialistas em Medicina Tropical e doenças infecciosas e parasitárias; no campo burocrático, entre programas estaduais, particularmente o paulista, e Programa Nacional; no espaço militante, entre associações específicas de luta contra a aids e 
movimentos em que a aids apareceu como questão transversal, entre as "king-ONGs" e ONGs menores, entre ONGs políticas e ONGs assistenciais, além da disputa entre ONGs de pessoas vivendo com HIV/aids e as demais ONGs/aids; no campo científico, entre grupos de diferentes instituições de pesquisa e ensino superior (USP X Unifesp, UFRJ X Fiocruz), entre diferentes gerações de pesquisadores.

As principais disputas entre alguns agentes responsáveis pelo Programa Nacional e as associações específicas de luta contra a aids deram-se até 1993 em torno das campanhas preventivas - qual deveria ser a população alvo: grupos específicos ou população geral, se deveria ser adotada uma linguagem técnica ou popular, o que poderia ser dito e o que não poderia ser dito, que termos usar etc. A partir do surgimento do primeiro medicamento ARV e sempre que surgissem novos medicamentos em torno do tratamento. Depois do primeiro acordo de empréstimo, acerca do financiamento de projetos de ONGs e da participação na Comissão Nacional - qual o papel da comissão, sua função, quem a integra -, principalmente com o surgimento de novas organizações não governamentais.

O que prevaleceu nas campanhas governamentais foi a concepção técnica dos agentes do campo burocrático, ainda que com influência do campo religioso, que, em algumas oportunidades, conseguiu interferir no conteúdo das mensagens, e do espaço militante que influenciou a promoção de um discurso mais inclusivo e menos estigmatizante.

A relação da doença com a sexualidade e o uso de drogas injetáveis levaram a uma influência do discurso religioso sobre a concepção da doença, inculcada especialmente pela igreja católica, predominante no país, relacionada ao pecado, à transgressão moral e ao castigo divino. Nesse sentido, os grupos homossexuais opunham-se ao discurso da igreja.

Na imprensa, a aids era apresentada como um problema dos homens homossexuais norte-americanos, ou seja, um problema estrangeiro e relacionado a uma minoria.

Inicialmente denominada peste gay, câncer gay, câncer rosa, quando a nova doença passou a ser denominada Síndrome da Imunodeficiência Adquirida (Sida) ou, em inglês, Acquired Immunodeficiency Syndrome (Aids), o termo estrangeiro foi incorporado imediatamente pelos 
médicos e pela imprensa. O Brasil foi o único país da América Latina que não adotou o termo sida. Um estrangeirismo, uma submissão tanto no campo científico como cultural aos EUA, que foi racionalizado através de justificativas relacionadas ao nome da santa padroeira do país (influência religiosa), ao apelido do nome Aparecida e formalizada em uma reunião no Ministério da Saúde para definir o termo a ser utilizado.

As semelhanças entre Brasil e França aparecem também quanto às primeiras medidas adotadas pelo Ministério da Saúde de cada um dos países: vigilância epidemiológica, educação e informação sanitária, visando esclarecer os meios de transmissão, testagem voluntária e na caracterização de uma epidemia que afetava toda a população.

Essa última estratégia tinha por objetivo reduzir o estigma e a discriminação dos grupos mais afetados, de modo que no Brasil, acordou-se que as campanhas seriam voltadas para a população geral. Isso só foi alterado a partir do final da década de 1980, com o Projeto Previna, voltado para população carcerária, profissionais do sexo, usuários de drogas injetáveis, crianças e adolescentes em situação de risco, garimpeiros e homossexuais. Contudo, as principais críticas de oposição à política governamental residiam na ausência de resposta assistencial e na concepção das campanhas preventivas de veiculação nacional, essa última talvez a questão de maior controvérsia ao interior do espaço aids. Controvérsia que perdurou até 2012, quando após a apresentação oficial da campanha para o carnaval voltada prioritariamente aos jovens homossexuais, o Ministério da Saúde mudou a mensagem da campanha para evitar atritos com a bancada evangélica, reacendendo a crítica das ONG/aids.

O fato de o campo médico ter sempre exercido papel dominante, bem como a conjuntura do movimento sanitário, a participação de epidemiologistas na gestão do programa e a participação crítica das organizações não governamentais concorreram para a formulação de uma política avança$\mathrm{da}$, que se contrapôs às recomendações das agências internacionais, de modo a garantir não apenas ações de caráter preventivo, priorizadas até o final da década de 1980, mas também, o acesso ao tratamento, iniciado em 1988 com a distribuição de medicamentos para doenças oportunistas, evoluindo para os antirretrovirais em 1991 e universalizando o acesso em 
1996 através da Lei 9.313. Assim, essa política, baseada na integralidade da atenção à saúde, foi sendo conquistada e construída ao longo do período estudado (1981 a 2001), resultando da incorporação de novas tecnologias à medida que o saber e as práticas médicas sobre a doença avançavam como resultado da complexa configuração desse espaço social específico diante de condições históricas de possibilidade.

Ainda que o espaço aids tenha sido dominado pelo campo médico, dentre os principais agentes formuladores da política nacional existiam profissionais graduados em outras áreas e agentes pertencentes ao campo burocrático e ao espaço militante. O desenvolvimento da política levou a uma influência crescente do campo burocrático nesse espaço, de modo que, a partir de meados da década de 1990, o Programa Nacional passou a assumir um papel dominante, o que modificou significativamente as relações ao interior do espaço aids, levando a uma redução gradual da crítica de oposição à política pelas ONGs/aids, que passaram a brigar pelo cumprimento dos direitos adquiridos pelos portadores de HIV/aids. Contribuíram para essa posição de autoridade dos técnicos do Programa Nacional, o aporte financeiro garantido pelos acordos de empréstimo junto ao Banco Mundial, possibilitando o financiamento de ações nos estados e municípios, bem como de projetos junto às ONGs; e a decisão política dos Ministros da Saúde e dos presidentes da república em assumir, contra as orientações do Banco Mundial, da OMS e das pressões das indústrias farmacêuticas, a garantia ao tratamento para portadores de HIV/aids.

O acordo de empréstimo junto ao Banco Mundial possibilitou o financiamento por parte do Ministério da Saúde de projetos de ONGs voltados para prevenção da doença e assistência aos portadores de HIV/aids, induzindo também à criação de novas associações, a maioria delas, ao contrário das ONGs mais antigas e mais consolidadas, passaram a depender dos recursos governamentais.

O financiamento do Banco Mundial, apesar de polêmico e de ter suscitado reações diversas, foi considerado como facilitador da expansão e consolidação das ONGs/aids, bem como contribuiu para a estruturação inicial de uma rede de serviços de saúde e apoio diagnóstico, e para a 
capacitação técnica de profissionais, questões fundamentais à universalização do tratamento, viabilizado através de recursos do tesouro nacional.

A política brasileira de controle da aids ganhou reconhecimento internacional a partir do estabelecimento da estratégia de acesso universal aos ARVs em 1996. Associado a isso, as evidências do impacto positivo da política brasileira sobre os indicadores de morbimortalidade levaram diversas organizações internacionais que financiavam ações de ONGs/aids no Brasil a direcionar os recursos para países com respostas menos estruturadas frente à epidemia de aids e quadros epidemiológicos mais graves. Esse fato reduziu a oferta de financiamento para ONGs/aids, deixando os editais do Ministério da Saúde na única opção para o financiamento de diversas associações. A descentralização dos recursos para estados e municípios, a partir de 2002, associada à baixa capacidade de gasto dos programas estaduais e diferentes legislações fiscais comprometeram o repasse de recursos às ONGs, levando a um desfinanciamento do setor.

As relações de força entre os subespaços militante, burocrático e científico, com agentes engajados também no movimento da reforma sanitária, em uma conjuntura de redemocratização do país e de conformação do Sistema Único de Saúde contribuíram para a formulação de uma política baseada na saúde como um direito e dever do Estado. Foi essa premissa constitucional que garantiu a base legal para a demanda em juízo pelas assessorias jurídicas de diversas ONGs da garantia de acesso ao tratamento.

A luta pela sustentabilidade da estratégia de acesso universal a ARV levou a disputas internacionais, colocando o país em uma posição de destaque no cenário internacional. Da mesma forma, a política de aids, em especial a questão de acesso a medicamentos, tornou-se importante no campo político, no qual a maternidade/paternidade da política virou objeto de disputa, ganhando inclusive um caráter eleitoreiro.

Em que pese o relativo sucesso da política nacional e mesmo a vanguarda assumida pelo país, na opinião de diversos militantes/ativistas e mesmo de agentes do campo burocrático a sua continuidade e sustentabilidade não têm sido asseguradas. O Brasil parece ter se acomodado com 
os êxitos pretéritos. ${ }^{125}$ Para além de assegurar as características consideradas como exemplares, a saber, a integralidade, a universalidade e a não discriminação, a compreensão das razões históricas, que permitiram a elaboração dessa política, evidenciam que a existência de um sistema de saúde público organizado e universal foi uma das condições para que essa política se tornasse possível, assim como a participação social, para além das instâncias formais. As pessoas com HIV/aids tornaram-se agentes da sua própria história, não restringindo a sua participação ao subespaço militante, mas assumindo posições também no campo burocrático. Esse trânsito ao interior da burocracia estatal foi garantido pelo financiamento internacional, que permitiu a contratação de profissionais através de projetos, garantindo um corpo técnico qualificado e diversificado, engajado na luta pelo controle da epidemia. $\mathrm{O}$ ativismo da aids profissionalizou-se, não vivendo de voluntários. Embora enfrentando problemas de desfinanciamento, continua ativo, mais silencioso talvez, mas se manifestando sempre que necessário e aprimorando-se continuamente.

O engajamento político-militante profissional associado à luta contra a aids, no Brasil, não encontra precedentes na história da saúde no país. Se podemos perceber um reflexo da ideia, da proposta, do projeto, do movimento e do processo da reforma sanitária brasileira, conforme descrito por Paim (2008), no movimento de luta contra a epidemia da aids (espaço aids), isso acontece porque a história da política de aids não se desvincula da construção histórica de um Sistema Único de Saúde cujas diretrizes incluem a justiça, a equidade e a universalidade. A política da aids compartilha dos mesmos problemas do SUS, mas tendo um corpo técnico diferenciado pelo engajamento militante ao interior do ministério que promove a participação popular, e um movimento associativo que exerce de fato o controle social.

Segundo um ex-dirigente do Programa Nacional e representante da Unaids no Brasil, "[... ] - Brasil está perdendo o momento político e tecnológico da segunda revolução na aids. [...] Que é adotar a abordagem da tecnologia CD4, abaixo de 500, trata para fim de prevenção. [...] o Brasil não pode ficar só repousando no que fez, tem que fazer coisas novas e o Brasil podia ser exemplo para o mundo novamente, se tomasse a decisão política, por que tecnicamente já está fundamentado". (E27) 
A análise sócio-histórica aqui realizada identificou diversos fenômenos responsáveis pela consolidação do espaço aids, bem como pelas características da política nacional de controle para este agravo. Não somente auxilia a compreensão acerca da complexidade dos processos evolutivos como pode contribuir para a análise de outras políticas de saúde e no seu aperfeiçoamento na direção dos princípios da Reforma Sanitária Brasileira. 


\section{Posfácio}

A análise sócio-histórica de uma política de saúde permite compreender as razões e as intrincadas relações sociais que resultam na construção de um espaço social diverso, formado por agentes oriundos de diferentes campos sociais, mas que possuem um interesse em comum: a produção de uma resposta estatal a um problema socialmente construído. No caso, o livro de Sandra Garrido, Política Nacional de Aids: a construção da resposta governamental à epidemia HIV/aids no Brasil, vem preencher uma lacuna na literatura sobre o tema.

O recurso à sociologia de Bourdieu permitiu integrar as abordagens existentes. Sem omitir o papel dos movimentos sociais, particularmente dos movimentos homossexuais e do movimento sanitário, a abordagem adotada permitiu revelar a participação de campos sociais antes secundarizados como o campo médico, o campo científico e o campo burocrático. Além disso, apreendeu a influência de disposições oriundas de outros campos que não tiveram grande participação, mas interferiram na formulação da política por meio dos esquemas de percepção dos seus agentes, a exemplo da religião.

Articulando a análise das trajetórias dos agentes com as condições históricas de possibilidade, Sandra revela como o elevado capital social de algumas das lideranças do movimento homossexual permitiram a interação com agentes vinculados à reforma sanitária e posicionados estrategicamente no sistema de saúde paulista. Também como as disputas ao interior do campo médico, entre escolas e especialidades, e algumas características do desenvolvimento do campo científico na área da imunopatologia possibilitaram o desenvolvimento de trajetórias de médicos que não apenas diagnosticaram os primeiros casos da doença como também de pesquisadores que isolaram o vírus no país e consolidaram um conhecimento técnico-científico nacional sobre a doença. Não menos 
importante foi o entrelaçamento das trajetórias desses agentes com médicos militantes da Reforma Sanitária e com posições de direção administrativa no campo burocrático que perceberam a relevância do problema e organizaram a resposta à epidemia ao interior do Ministério da Saúde. Dessa forma, uma doença que atingia predominantemente grupos socialmente marginalizados, de pequena magnitude pôde converter-se em política nacional com ênfase na integralidade do cuidado remando contra a maré das orientações do Banco Mundial.

O livro que é um produto da tese de doutorado de Sandra desenvolveu-se ao interior do grupo de pesquisa aglutinado há mais de 15 anos em torno da análise acerca das relações entre o espaço social e a saúde em uma perspectiva Bourdieusiana. Resultou também da articulação de duas linhas de pesquisa que demandavam um referencial teórico desse porte, a saber, a análise dos determinantes sociais da saúde e a avaliação das políticas e programas de saúde. Por outro lado, a inserção do projeto O Espaço da Saúde Coletiva ao interior do Diretório de Política, Gestão e Avaliação em saúde permitiu o diálogo com outras abordagens e perspectivas na análise sociológica das políticas de saúde. Essas opções também possibilitaram o intercâmbio com o Centro de Sociologia Europeia que em muito contribuiu para a definição dessa nova linha de pesquisas - os estudos socio-historicos e a tese de Sandra em particular.

Situar as condições historicas de possibilidade da produção de uma tese de doutorado, na qualidade da tese de Sandra Garrido, não significa secundarizar o protagonismo do agente social - no caso Sandra - na contribuição original desse estudo. É necessário para mostrar o processo de constituição de um habitus de pesquisadora em saúde coletiva que vinha sendo formado ao longo da sua trajetória anterior - dirigida ao campo científico, à saúde coletiva e em particular a área das políticas, gestão e avaliação em saúde: residência, mestrado e participação em projetos de cooperação técnica ao lado de vários artigos já publicados.

Enfrentar um objeto novo, distante da sua formação profissional prévia, ao interior também de um projeto cuja metodologia ainda estava por ser definida, revelou a disposição de Sandra de correr os riscos que o empreendimento de uma investigação científica original traz, 
principalmente no afastamento dos percursos conhecidos e confortaveis. Não que o referencial teórico adotado não oferecesse um apoio bastante substantivo. Mas, exatamente por se apoiar na epistemologia do não e de não ser um referencial de receitas prontas, exigiu de Sandra uma criatividade e iniciativa na solução dos problemas práticos da pesquisa, particularmente no que diz respeito à sumarização dos achados empíricos e na análise da articulação entre as trajetorias dos formuladores da política da aids com a análise das condições historicas de possibilidade para a emergencia e desenvolvimento dessa propria política.

O objeto inicial de Sandra era o campo burocratico como um sub -espaço da saúde coletiva. Contudo, seguindo a experiencia previa de Bourdieu e principalmente de Pinell, que tomaram em suas investigações objetos bem concretos para, a partir deles, entender as conexões sociais mais amplas. Sandra escolheu analisar as políticas de luta contra a aids tendo em vista a sua relativa consolidação ao longo dessas quatro ultimas décadas. A exploração do empírico, guiada pela teoria, permitiu apreender um espaço muito mais complexo do que aquele imaginado no início do estudo, formado pelo imbricamento de diversos campos sociais. A distinção do espaço militante do espaço político também foi importante para a compreensão dos movimentos sociais que interagiram no espaço aids. A comparação com outras experiencias internacionais, ainda que não feita de forma sistemática mas inevitavel, tendo em vista a inserção durante o sanduíche no CSE, mostrou os aspectos universais dessa política. Trouxe também elementos explicativos para a sua especificidade e relevância no contexto internacional.

Um estudo cuidadoso, que mobilizou adequadamente conceitos teóricos para a interpretação dos achados empíricos, é um exemplo das possibilidades e do potencial do referencial teórico adotado. A análise das diferentes conjunturas sanitárias e políticas permitiu também uma visão do longo prazo e das transformações ocorridas no espaço aids, que sofreu progressiva diferenciação no seu polo técnico e no polo militante.

Revela, sobretudo, para além da ação racional, diversos outros móveis que concorrem à formulação e implementação de uma política de saúde, trazendo uma contribuição não apenas ao conhecimento sobre o tema 
mas, sobretudo, reunindo elementos que possibilitam um novo olhar sobre a situação atual da política analisada.

Ligia Maria Vieira da Silva

Salvador, janeiro de 2017 


\section{Referências}

1991 - Se você não se cuidar a aids vai te pegar. In: BRASIL. Ministério da Saúde. Departamento de DST, Aids e Hepatites Virais. Brasília, DF, 1991. Portal sobre aids, doenças sexualmente transmissíveis e hepatites virais. 1 imagem da página. Disponível em: <http://www.aids.gov.br/index. php?q=midia/1991-se-voce-nao-se-cuidar-aids-vai-te-pegar $>$. Acesso em: 10 dez. 2012.

A MULTIPLICAÇÃO do mal: a aids se espalha. Veja, São Paulo, n. 884, p. 56-60, 14 ago. 1985. Disponível em: <https://acervo.veja.abril.com.br|\#/ edition/33663? page $=18$ section=1 $>$.Acesso em: 15 set. 2011 .

ABBADE, Á. C. da S.; BAIÃO, F. (Org.). 100 nomes que fizeram a história da luta contra a aids no Brasil. São Paulo: GAPA BR SP, 2010.

ABREU, A. A. de et al. (Coord.). Dicionário histórico-biográfico brasileiro: pós 1930. 2. ed. Rio de Janeiro: FGV, CPDOC, 2001. Disponível em: $<$ http://www.fgv.br/cpdoc/acervo/arquivo >. Acesso em: 10 jul. 2011. “AFRICANIZAÇÃO" pode mudar quadro no país. Folha de S. Paulo, São Paulo, 19 ago. 1988. Cidades, p. C-2.

AGÊNCIA NACIONAL DE VIGILÂNCIA SANITÁRIA (Brasil) ANVISA. Segurança e controle de qualidade no laboratório de microbiologia clínica. Brasília, DF, 2004. módulo II.

AIDS, pare com isso!: avião. Brasília, DF: Ministério da Saúde, 1988a. 1 vídeo (1 min), son., color.

AIDS, pare com isso!: perigos da noite. Brasília, DF: Ministério da Saúde, 1988b. 1 vídeo (1 min), son., color.

AIDS, você precisa saber evitar: carinho. Brasília, DF: Ministério da Saúde, 1987a. 1 vídeo online (30 s), son., color. Disponível em: <http:// www.aids.gov.br/pagina/videos>. Acesso em: 15 set. 2012. 
AIDS, você precisa saber evitar: doe sangue. Brasília, DF: Ministério da Saúde, 1987b. 1 vídeo online (30 s), son., color. Disponível em: <http:// www.aids.gov.br/pagina/videos $>$. Acesso em: 15 set. 2012.

AIDS, você precisa saber evitar: dominó. Brasília, DF: Ministério da Saúde, 1987c. 1 vídeo online (30 s), son., color. Disponível em: <http:// www.aids.gov.br/pagina/videos $>$. Acesso em: 15 set. 2012.

AIDS, você precisa saber evitar: seringas. Brasília, DF: Ministério da Saúde, 1987d. 1 vídeo online (30 s), son., color. Disponível em: <http:// www.aids.gov.br/pagina/videos>. Acesso em: 15 set. 2012.

AIDS: o número de casos e o caso dos números. Boletim ABIA, Rio de Janeiro, n. 3, p. 1-2, 1 jul. 1988c.

AINSWORTH, M.; BEYRER, C.; SOUCAT, A. Aids and public policy: the lessons and challenges of "success" in Thailand. Health Policy, [S.1.], v. 64, n. 1, p. 13-37, Apr. 2003. Disponível em: <https://ac.elscdn.com/So168851002000799/1-S2.O-So168851002000799-main. pdf?_tid=f732c7aa-d8f6-11e7-97c2-oooooaacb35f\&acdnat=1512394268_ f2e41074e2287158e3274be3906847bb>. Acesso em: 1 mar. 2010.

ALBUQUERQUE, J. L. de. Médico deteta HIV-2 em sangue de aidéticos brasileiros. Folha de S. Paulo, São Paulo, 15 jun. 1988. Primeiro Caderno, Cidades, p. A-11.

AMATO NETO, V. et al. Síndrome da imunodeficiência adquirida (Aids): descrição do primeiro caso autóctone do Brasil e estudo imunológico. Revista Paulista de Medicina, São Paulo, v. 101, n. 4, p. 165-168, 1983. APLICAÇÃO de teste anti-HIV para estrangeiros. Boletim Epidemiológico Aids, Brasília, DF, ano 1, n. 8, p. 1-3, 1988.

ARAZOZA, H. de et al. The HIV/aids epidemic in Cuba: description and tentative explanation of its low HIV prevalence. BMC Infectious Diseases, [S.1.], v. 7, n. 130, p. 1-6, nov. 2007.

ARNS, P. E. Dom Paulo Evaristo Arns: entrevista. In: MEMÓRIA Roda Viva. São Paulo: Fundação Padre Anchieta, 25 dez. 1995. Entrevista concedida ao programa Roda Viva. Disponível em: < http://www.rodaviva. fapesp.br/materia/28/entrevistados/dom_paulo_evaristo_arns_1995. htm>. Acesso em: 7 set. 2012. 


\section{ASSEMBLÉIA GERAL DA CONFERÊNCIA NACIONAL DOS BISPOS}

DO BRASIL, 41., 2003, Indaiatuba. Diretrizes gerais da ação evangelizadora da igreja no Brasil 2003-2006. Indaiatuba: CNBB, 2003. Disponível em: <http://www.cnbb.org.br/arquivo/index.php?option=com_ docman\&view=download\&alias=134-71-diretrizes-gerais-daacao-evangelizadora-da-igreja-no-brasil-2003-2006\&category_ slug=documentos-cnbb\&Itemid=252>. Acesso em: 1 out. 2012.

ATÉ MOSCAS e mosquitos podem portar o vírus da aids, afirma o médico Veronesi. Folha de S. Paulo, São Paulo, 18 fev. 1987. Primeiro Caderno, Exterior, Cidades, p. A-7.

AZEVEDO, M. G. da S. L. e C. Acesso gratuito aos medicamentos antirretrovirais: contribuição do Legislativo para a política brasileira de combate à Aids. 2010.50 f. Monografia (Especialização em Legislativo e Políticas Públicas) - Centro de Formação, Treinamento e Aperfeiçoamento, Câmara dos Deputados, Brasília, DF, 2010.

AZIM, T. et al. HIV and Aids in Bangladesh. Journal of Health, Population and Nutrition, [S.1.], v. 26, n.3, p.311-324, 2008. Disponível em: <https:/ www.ncbi.nlm.nih.gov/pmc/articles/PMC2740703/>. Acesso em: 1 mar. 2010.

BARATA, G. F. A primeira década da aids no Brasil: o Fantástico apresenta a doença ao público (1983-1992). 2006. 196 f. Dissertação (Mestrado em História Social) - Faculdade de Filosofia, Letras e Ciências Humanas, Universidade de São Paulo, São Paulo, 2006.

BARATA, R. B.; GOLDBAUM, M. Perfil dos pesquisadores com bolsa de produtividade em pesquisa do CNPq da área de saúde coletiva. Cadernos de Saúde Pública, Rio de Janeiro, v. 19, n. 6, p. 1863-1876, nov./dez. 2003.

BARBOZA, R. Gestão do programa estadual DST/Aids de São Paulo: uma análise do processo de descentralização das ações no período de 1994 a 2003. 2006. 184f. Dissertação (Mestrado em Ciências) - Coordenadoria de Controle de Doenças, Secretaria de Estado da Saúde de São Paulo, São Paulo, 2006.

BASTOS, F. I.; BARCELLOS, C. Geografia social da aids no Brasil. Revista de Saúde Pública, São Paulo, v. 29, n. 1, p.52-62, 1995. 
BELOQUI, J. Uma história de luta contada em dez edições. Boletim Vacinas Anti-HIV/aids, São Paulo, n. 10, p. 3-4, dez. 2003.

BEYRER, C.; GAURI, V.; VAILLANCOURT, D. Evaluation of the World Bank's assistance in responding to the Aids epidemic: Brazil case study. Washington, DC: The World Bank Operations Evaluation Department, 2005.

BIANCARELLI, A. Pais vão a juiz para matricular filha com aids. Folha de S. Paulo, São Paulo, 1 maio 1992. Cotidiano, Terceiro caderno, p. 4.

BOLETIM EPIDEMIOLÓGICO AIDS. Brasília, DF: Ministério da Saúde, ano 1, n. 1, 1987a. 1 folheto.

BOLETIM EPIDEMIOLÓGICO AIDS. Brasília, DF: Ministério da Saúde, ano 1, n. 2, 1987b. 1 folheto.

BOLETIM EPIDEMIOLÓGICO AIDS. Brasília, DF: Ministério da Saúde, ano 2, n. 4, 1988a.

BOLETIM EPIDEMIOLÓGICO AIDS. Brasília, DF: Ministério da Saúde, ano 2, n. 5, 1988b.

BOLETIM EPIDEMIOLÓGICO AIDS. Brasília, DF: Ministério da Saúde, ano 3 , n. 15, 1990. 1 folheto.

BOLETIM EPIDEMIOLÓGICO AIDS. Brasília, DF: Ministério da Saúde, ano 14, n. 2, abr./jun. 2001.

BOLETIM EPIDEMIOLÓGICO AIDS/DST.Brasília, DF: Ministério da Saúde, ano 6, n. 1, 2009.

BOLETIM EPIDEMIOLÓGICO AIDS/DST. Brasília, DF: Ministério da Saúde, ano 8, n. 1, 2011.

BOLETIM EPIDEMIOLÓGICO DST-AIDS. Brasília, DF: Ministério da Saúde, ano 1, n. 5 1987c.

BOLETIM EPIDEMIOLÓGICO HIV/AIDS. Brasília, DF: Ministério da Saúde, ano 3, n. 1, 2014.

BOLETIM EPIDEMIOLÓGICO HIV/AIDS. Brasília, DF: Ministério da Saúde, ano 4, n. 1, 2015.

BONIFÁCIO, R. Livre pensar. Boletim ABIA, Rio de Janeiro, n. 19, p. 9-10, 19 maio 1993. 
BOUER, J. Terapia consegue... Folha de S. Paulo, São Paulo, 12 jul. 1996. Primeiro Caderno, Mundo, p. 16.

BOURDIEU, P. A distinção: crítica social do julgamento. São Paulo: EDUSP; Porto Alegre: Zouk, 2008.

BOURDIEU, P. De la maison du roi à la raison d'état: un modèle de la genèse du champ bureaucratique. Actes de la recherche en sciences sociales, Paris, v. 118, p. 55-68, juin 1997. Disponível em: <http://www. persee.fr/web/revues/home/prescript/article/arss_0335-5322_1997_ num_118_1_3222>. Acesso em: 1 set. 2011.

BOURDIEU, P. Gênese e estrutura do campo religioso. In: BOURDIEU, P. Economia das trocas simbólicas. São Paulo: Perspectiva, 2005. p. 27-98.

BOURDIEU, P. Homo academicus. Florianópolis: Ed.UFSC, 2011.

BOURDIEU, P. Le capital social: notes provisories. Actes de la recherche en sciences sociales, Paris, v.31, n. 1, p. 2-3, janv. 1980. Numéro thématique: Le capital social.

BOURDIEU, P. O poder simbólico. 4. ed. Rio de Janeiro: Bertrand Brasil, 2001.

BOURDIEU, P. Razões práticas: sobre a teoria da ação. 8. ed. Campinas: Papirus, 1996.

BOURDIEU, P. Sur l'État: cours au Collège de France, 1989-1992. Paris: Raisons d'agir-Seuil, 2012.

BOYER, S. et al. Non-adherence to antiretroviral treatment and unplanned treatment interruption among people living with HIV/aids in Cameroon: individual and healthcare supply-related factors. Social Science \& Medicine, [S.1.], v. 72, n. 8, p. 1383-1392, Apr. 2011. Disponível em: $<$ http://www.ncbi.nlm.nih.gov/pubmed/21470734>. Acesso em: 1 maio 2011.

BRANDÃO, M. Frente parlamentar contra aids define atuação. Agência Câmara Notícias, Brasília, DF, 1 nov. 2001. Disponível em: <http://www2. camara.leg.br/camaranoticias/noticias/NAO-INFORMADO/12432FRENTE-PARLAMENTAR-CONTRA-AIDS-DEFINE-ATUACAO.html>. Acessado em: 7 dez. 2012. 
BRASIL. Congresso Nacional. Câmara dos Deputados. Departamento de Taquigrafia, Revisão e Redação. [Discursos e notas taquigráficas da sessão 223.3.51.O, de 31 de outubro de 2001]. Brasília, DF, 2001a. Disponível em: <http://www.camara.gov.br/internet/plenario/notas/ordinari/2001/10/ V311001.pdf>. Acesso em: 2 set. 2012.

BRASIL. Congresso Nacional. Câmara dos Deputados. Redação final do substitutivo da Câmara dos Deputados ao Projeto de Lei n².375-A, de 1996, do Senado Federal. Substitutivo da Câmara dos Deputados ao Projeto de Lei no 2.375-A, de 1996, do Senado Federal (PLS nº 158/96, na Casa de origem), que "dispõe sobre a distribuição gratuita de medicamentos aos portadores do HIV e doentes de AIDS”. Brasília, DF, 1996a.

BRASIL. Constituição (1891). Constituição da República dos Estados Unidos do Brasil. Diário do Congresso Nacional, Poder Legislativo, Rio de Janeiro, 24 fev. 1891. p. 523.

BRASIL. Constituição (1988). Constituição da República Federativa do Brasil. Brasília, DF: Senado, 1988a.

BRASIL. Decreto-Lei no 2.848, de 7 de dezembro de 1940. Código Penal. Diário Oficial [dos] Estados Unidos do Brasil, Poder Executivo, Rio de Janeiro, 31 dez. 1940.

BRASIL. Lei $\mathrm{n}^{\circ}$ 7.649, de 25 de janeiro de 1988. Estabelece a obrigatoriedade do cadastramento dos doadores de sangue bem como a realização de exames laboratoriais no sangue coletado, visando a prevenir a propagação de doenças, e dá outras providências. Diário Oficial [da] República Federativa do Brasil, Poder Legislativo, Brasília, DF, 27jan. 1988b.

BRASIL. Lei no 8.142, de 28 de dezembro de 1990. Dispõe sobre a participação da comunidade na gestão do Sistema Único de Saúde (SUS) e sobre as transferências intergovernamentais de recursos financeiros na área da saúde e dá outras providências. Diário Oficial [da] República Federativa do Brasil, Poder Legislativo, Brasília, DF, 31 dez. 1990.

BRASIL. Lei $\mathrm{n}^{\mathrm{O}}$ 10.205, de 21 de março de 2001. Regulamenta o $\S 4^{\mathrm{o}}$ do art. 199 da Constituição Federal, relativo à coleta, processamento, estocagem, distribuição e aplicação do sangue, seus componentes e derivados, estabelece o ordenamento institucional indispensável à execução adequada dessas atividades, e dá outras providências. Diário 
Oficial [da] República Federativa do Brasil, Poder Legislativo, Brasília, DF, 22 mar. $2001 \mathrm{~b}$.

BRASIL. Lei $n^{0}$ 10.409, de 11 de janeiro de 2002. Dispõe sobre a prevenção, o tratamento, a fiscalização, o controle e a repressão à produção, ao uso e ao tráfico ilícitos de produtos, substâncias ou drogas ilícitas que causem dependência física ou psíquica, assim elencados pelo Ministério da Saúde, e dá outras providências. Diário Oficial [da] República Federativa do Brasil, Poder Legislativo, Brasília, DF, 14jan. 2002. Seção 1, p. 1.

BRASIL. Ministério da Saúde. Aids e a Constituinte: participe dos debates. 1986a. 1 cartaz.

BRASIL. Ministério da Saúde. Aids e Constituinte: subtema da VIII Conferência Nacional de Saúde. Brasília, DF, 1986b.

BRASIL. Ministério da Saúde. Comissão nacional de aids: 1986-1994. Brasília, DF, 1994a.

BRASIL. Ministério da Saúde. Departamento de DST, Aids e Hepatites Virais. Instrução normativa de 13 de junho de 2014. Estabelece procedimentos relacionados à notificação compulsória de casos de infecção pelo HIV no Brasil. Brasília, DF, 2014a.

BRASIL. Ministério da Saúde. [Histórico]. Brasília, DF, 1985 a. Mimeografado.

BRASIL. Ministério da Saúde. Portaria n ${ }^{\circ}$ 101, de 10 de março de 1987. Constitui a Comissão Nacional de Controle da Síndrome da Imunodeficiência Adquirida. In: BRASIL. Ministério da Saúde. Comissão nacional de aids: 1986-1994. Brasília, DF, 1994a. p. 12-13. Reprodução de portaria originalmente publicada no Diário Oficial [da] República Federativa do Brasil, Brasília, DF, 12 mar. 1987. Seção 2, p. 1234.

BRASIL. Ministério da Saúde. Portaria nº 199, de 25 de abril de 1986. Cria a Comissão Nacional de Assessoramento em Aids de caráter técnicoconsultivo, interministerial. Diário Oficial $[$ da $]$ República Federativa do Brasil, Brasília, DF, 28 abr. 1986c.

BRASIL. Ministério da Saúde. Portaria nº 218, de 2 de março de 2000. Inclui membros na Comissão Nacional de Aids - CNAIDS. Diário Oficial [da] República Federativa do Brasil, Brasília, DF, 8 mar. 2000 . Seção 2, p. 8. 
BRASIL. Ministério da Saúde. Portaria n² 236, de 2 de maio de 1985. Cria o Programa de Controle da SIDA ou AIDS (hoje Departamento de DST, Aids e Hepatites Virais). Diário Oficial [da] República Federativa do Brasil, Brasília, DF, 6 maio 1985b. Seção 1, p. 6856.

BRASIL. Ministério da Saúde. Portaria nº 326 de 24 de março de 2000. Altera a presidência da Comissão Nacional de Aids - CNAIDS. Diário Oficial [da] República Federativa do Brasil, Brasília, DF, 28 mar. 2000 b. Seção 2, p. 6.

BRASIL. Ministério da Saúde. Portaria no 437 , de 22 de julho de 1988. Constitui a Comissão Nacional de Controle da Síndrome da Imunodeficiência Adquirida - CNCSIDA, com objetivo de assessorar o Ministerio da Saúde na definição de mecanismos técnicos operacionais para controle da Aids. Diário Oficial [da] República Federativa do Brasil, Brasília, DF, 25 jul. 1988c.

BRASIL. Ministério da Saúde. Portaria nº 553, de 14 de maio de 1992. Reformula a composição da Comissão Nacional de Controle da Síndrome da Imunodeficiência Adquirida - CNCSIDA, dando as suas competencias, a sua composição e revogando a portaria 437, de 22/07/1988. Diário Oficial [da] República Federativa do Brasil, Brasília, DF, 18 maio 1992.

BRASIL. Ministério da Saúde. Portaria nº 1.028, de 31 de maio de 1994. Reformula a composição, dá nova denominação e outras competências a Comissão Nacional de Controle da Síndrome da Imunodeficiência Adquirida - CNCSIDA. Diário Oficial [da] República Federativa do Brasil, Brasília, DF, 3 jun. 1994b.

BRASIL. Ministério da Saúde. Portaria no 1.271, de 6 de junho de 2014. Define a Lista Nacional de Notificação Compulsória de doenças, agravos e eventos de saúde pública nos serviços de saúde públicos e privados em todo o território nacional, nos termos do anexo, e dá outras providências. Diário Oficial [da] República Federativa do Brasil, Brasília, DF, 9 jun. 2014b.

BRASIL. Ministério da Saúde. Portaria nº 1.468, de 19 de julho de 1996. Reformula a composição da Comissão Nacional de Aids - CNAIDS. Diário Oficial [da] República Federativa do Brasil, Brasília, DF, 22 jul. 1996b, seção 2, p. 5301. 
BRASIL. Ministério da Saúde. Se você não se cuidar a aids vai te pegar. [1991]. 1 cartaz.

BRASIL. Ministério da Saúde; Ministério da Previdência e Assistência Social. Aids: você precisa saber evitar. Brasília, DF, 1987. 3 cartazes.

BRASIL. Ministério do Planejamento, Orçamento e Gestão. Secretaria de Assuntos Internacionais. Manual de financiamentos externos do setor público com organismos multilaterais e agências bilaterais de crédito. Brasília, $\mathrm{DF}, 2005$.

BRINDEIRO, R. M. et al. Brazilian network for HIV drug resistance surveillance (HIV-BResNet): a survey of chronically infected individuals. AIDS, [S.1.], v. 17, n. 7, p. 1063-1069, 2003.

BROTAS, A. Pesquisador lembra os 20 anos do isolamento do HIV no Brasil. Agência Fiocruz de Notícias, Rio de Janeiro, 21 dez. 2007. Disponível em: <https://agencia.fiocruz.br/pesquisador-lembra-os-20-anos-doisolamento-do-hiv-no-brasil>. Acesso em: 10 fev. 2011.

BROWN, P. et al. Embodied health movements: new approaches to social movements in health. Sociology of Health \& Illness, [S.1.], v. 26, n. 1, p. 50-80, Jan. 2004. Disponível em: <http:// onlinelibrary.wiley.com/doi/10.1111/j.1467-9566.2004.00378.x/ abstract;jsessionid=93A47642FDCAB4ECDooFF448B563A04A.fo2to4>. Acesso em: 2 out. 2010.

CAMARGO JÚNIOR, K. R. de. As ciências da aids \& a aids das ciências: o discurso médico e a construção da aids. Rio de Janeiro: Relume-Dumará: ABIA, 1994.

CAMPANHA de prevenção começa dia 16. Folha de S. Paulo, São Paulo, 7 fev. 1987. Cidades, p. 12.

CAMPOS, L. C. M. Estado e terceiro setor na prestação de serviços públicos: o programa nacional de DST e Aids: 1994-2005. 2005. 218 f. Dissertação (Mestrado em Administração Pública e Governo) - Escola de Administração de Empresas de São Paulo, Fundação Getúlio Vargas, São Paulo, 2005.

CANDIDATOS prometem fiscalizar qualidade do sangue. Folha de $S$. Paulo, São Paulo, 11 out. 1989. Diretas-89, p. B-6. 
COHEN, J. Early AZT takes a pounding in french-british 'concorde' trial. Science, [S.1.], v. 260, n. 5105, p. 157, Apr. 9, 1993.

COMISSÃO Nacional de Aids: o que é e para que serve? Boletim ABIA, Rio de Janeiro, n. 21, p. 4-7, 3 nov. 1993.

CONFERÊNCIA NACIONAL DE SAÚDE, 8., 1986, Brasília, DF. Anais... Brasília, DF: Centro de Documentação do Ministério da Saúde, 1986. CONFERÊNCIA NACIONAL DOS BISPOS DO BRASIL - CNBB. Pastoral de DST/Aids. Porto Alegre, [20--]. Disponível em: $<$ http://www.pastoralaids.org.br/quemsomos.php>. Acesso em: 1 out. 2012. CONFERÊNCIA NACIONAL DOS BISPOS DO BRASIL - CNBB. Pronunciamentos da CNBB: 1992 - coletânea -1996. São Paulo: Paulinas, 1997.

CONGRESSO termina com crítica de médico ao Inamps. Folha de $S$. Paulo, São Paulo, 6 jun. 1983. Primeiro Caderno, Geral, p. 8.

CONTRERA, W. F. Gapas: uma resposta comunitária à epidemia da aids no Brasil. Brasília, DF: Ministério da Saúde, Secretaria de Políticas de Saúde, 2000.

CORREA, C. M. O acordo Trips e o acesso a medicamentos nos países em desenvolvimento. Sur: revista internacional de direitos humanos, São Paulo, v. 2, n.3, p. 26-39, 2005.

CORRÊA, J. As últimas novidades em tratamento em discussão no Rio. Boletim ABIA, Rio de Janeiro, n. 31, p. 7-10, jan./abr. 1996.

CÔRTES irá pesquisar o retrovírus HTLV-1. Folha de S. Paulo, São Paulo, 30 out. 1988. Cidades, p. C-5.

CÔRTES, E. Campanha da aids entra em sua terceira fase. Folha de S. Paulo, São Paulo, 16 jul. 1991. Cotidiano, Quarto caderno, p. 2.

COSTA FILHO, R. B. Divinização e direitos humanos: articulações entre governo e igreja católica. In: CONFERÊNCIA NACIONAL DOS BISPOS DO BRASIL - CNBB. Igreja e aids: presença e reposta. Porto Alegre: Pastoral de DST/Aids, 2004. p. 8-15.

CRIANÇAS e adolescentes em situação de risco - Recomendações da XI Reunião da Comissão Nacional de Controle da Síndrome da 
Imunodeficiência Adquirida. Boletim Epidemiológico Aids, Brasília, DF, ano 2, n. 10, p. 1-2, 1989.

DIAS, C. J. P. A trajetória soropositiva de Herbert Daniel (1989-1992). 2012. 133 f. Dissertação (Mestrado em História das Ciências e da Saúde) - Casa de Oswaldo Cruz, Fundação Oswaldo Cruz, Rio de Janeiro, 2012.

DOSSIÊ vacinas. Rio de Janeiro: Grupo Pela Vidda, 1992.

DOURADO, I. et al. Tendências da epidemia de aids no Brasil após a terapia anti-retroviral. Revista de Saúde Pública, São Paulo, v. 40, p. 9-17, 2006. Suplemento.

DROGA importada para tratamento da aids será liberada em 20 dias. Folha de S. Paulo, São Paulo, 11 out. 1988. Cidades, p. C-5.

EM JUNHO, aids atinge mais 190 em SP. Folha de S. Paulo, São Paulo, 7 jul. 1988. Cidades, Educação e Ciência, p. A-2O.

EPEGA, S. M. Biossegurança dentro do Asé. In: MOTT, L.; CERQUEIRA, M. (Org.). As religiões a fro-brasileiras na luta contra a aids. Salvador: Centro Baiano Anti-Aids, 1998. p. 29-36.

FACCHINI, R. Movimento homossexual no Brasil: recompondo um histórico. Cadernos AEL, Campinas, v. 10, n. 18/19, p. 82-125, 2003. FALCÃO, D. Preço do coquetel contra aids cai $72,5 \%$ em 5 anos. Folha de S. Paulo, São Paulo, 15 mar. 2000. Folha Vale, p. 1.

FALCÃO, D. Registros de casos de aids sobem 39\%. Folha de S. Paulo, São Paulo, 6 fev. 1997. Folha São Paulo, $3^{\circ}$ caderno, p. 6.

FALEIROS, V. de P. et al. A construção do SUS: histórias da reforma sanitária e do processo participativo. Brasília, DF: Ministério da Saúde, 2006.

FATAL, P. Invicta: aids aqui: toques, becos e saídas. Rio de Janeiro: GAPA, 1988.

FAUSTO NETO, A. Mortes em derrapagem: os casos Corona e Cazuza no discurso da comunicação de massa. Rio de Janeiro: Rio Fundo, 1991. FELTRIN, R. Gapa tenta coquetel anti-aids para mais 20. Folha de S. Paulo, São Paulo, 17 jul. 1996. Terceiro caderno, Folha São Paulo, p. 6. 
FONSECA, E. M. da. Resposta brasileira à epidemia de HIV/aids entre usuários de drogas injetáveis, 1995-2007: marcos, avanços e desafios. 2008. 139 f. Tese (Doutorado em Ciências) - Escola Nacional de Saúde Pública Sérgio Arouca, Fundação Oswaldo Cruz, Rio de Janeiro, 2008.

FONSECA, M. G. P.; SZWARCWALD, C. L.; BASTOS, F. I. Análise sóciodemográfica da epidemia de aids no Brasil, 1989-1997. Revista de Saúde Pública, São Paulo, v. 36, n. 6, p. 678-685, 2002.

FORMENTI, L. ONGs acusam governo de discriminar gays. Estadão, São Paulo, 11 fev. 2012. Disponível em: <http://www.estadao.com.br/noticias/ geral,ongs-acusam-governo-de-discriminar-gays,834415>. Acesso em: 2 out. 2012.

FRANÇA, M. S. J. Ciência em tempos de aids: uma análise da resposta pioneira de São Paulo à epidemia. 2008.195 f. Tese (Doutorado em História da Ciência) - Pontifícia Universidade Católica de São Paulo, São Paulo, 2008.

GALVÃO-CASTRO, B. et al. Isolation and antigenic characterization of human immunodeficiency virus (HIV) in Brazil. Memórias do Instituto Oswaldo Cruz, Rio de Janeiro, v. 82, n. 4, p. 453-456, out./dez. 1987.

GALVÃO, J. Aids no Brasil: a agenda de construção de uma epidemia. Rio de Janeiro: ABIA; São Paulo: Ed. 34, 2000.

GALVÃO, J. As respostas religiosas frente à epidemia de HIV/aids no Brasil. In: PARKER, R. (Org.). Políticas, instituições e aids: enfrentando a epidemia no Brasil. Rio de Janeiro: J. Zahar, 1997. p. 107-134.

GALVÃO, P. A. A.; LOMAR, A. V. A falta de informação e a aids. Folha de S. Paulo, São Paulo, 30 maio 1992. Cotidiano, Terceiro caderno, p. 3.

GAMBOA, T. Habemus Padre. Olhar Vital, Rio de Janeiro, 21 jul. 2005. Disponível em: <http://www.olharvital.ufrj.br/ ant/2005_07_21/2005_07_21_historiaviva.htm>. Acesso em: 12 out. 2012.

GARCIA, J. et al. Local impacts of religious discourses on rights to express same-sex sexual desires in peri-urban Rio de Janeiro. Sexuality Research and Social Policy, [S.1.], v. 6, n. 3, p. 44-60, Sept. 2009. Disponível em: <https://www.ncbi.nlm.nih.gov/pmc/articles/PMC2796836/>. Acesso em: 1 set. 2012. 
GARCIA, J.; PARKER, R. G. Resource mobilization for health advocacy: afro-brazilian religious organizations and HIV prevention and control. Social Science \& Medicine, [S.1.], v. 72, n. 12, p. 1930-1938, June 2011. Disponível em: <https:/www.ncbi.nlm.nih.gov/pmc/articles/ PMC2943557/>. Acesso em: 1 set. 2012.

GARCIA, M. A evolução do estudo da aids, por um de seus codescobridores. Instituto Oswaldo Cruz, Rio de Janeiro, 25 maio 2011. Disponível em: <http://www.fiocruz.br/ioc/cgi/cgilua.exe/sys/start. htm?infoid=1174\&sid=32>. Acesso em: 17 nov. 2011.

GARCIA, S. Expertise scientifique et capital militant: le rôle des médecins dans la lutte pour la légalisation de l'avortement. Actes de la recherche en sciences sociales, Paris, v. 158, n. 3, p. 96-115, 2005. Disponível em: $<$ https://www.cairn.info/revue-actes-de-la-recherche-en-sciencessociales-2005-3-p-96.htm>. Acesso em: 5 jun. 2012.

GÓMEZ, E. J. Responding to contested epidemics: democracy, international pressures, and the civic sources of institutional change in the United States and Brazil. 2008.522 f. Doctoral thesis (Doctorate in Philosophy) - Department of Political Science, Brown University, Providence, 2008. GÓMEZ, E. J. What the United States can learn from Brazil in response to HIV/aids: international reputation and strategic centralization in a context of health policy devolution. Health Policy and Planning, Oxford, v. 25, n. 6, p. 529-541, Nov. 2010.

GONÇALES JÚNIOR, F. L. et al. Infecção pelo Pneumocystis carinii em indivíduo adulto homossexual com imunodeficiência: a propósito de um caso. Revista Paulista de Medicina, São Paulo, v. 101, n. 4, p. 160-164, 1983.

GOULART, F. A. de A. A burocracia e outros atores sociais face ao Programa de Saúde da Família: alguns apontamentos. Revista de APS, Juiz de Fora, v. 9, n. 2, p. 180-189, jul./dez. 2006.

GOULART, F. A. de A. Experiências em saúde da família: cada caso é um caso? 2002.387 f. Tese (Doutorado em Saúde Pública) - Escola Nacional de Saúde Pública, Fundação Oswaldo Cruz, Rio de Janeiro, 2002.

GOVERNO afirma que não faltarão leitos para a aids. Folha de S. Paulo, São Paulo, 14 jan. 1987. Primeiro caderno, Cidades, p. A-12. 
GOVERNO Collor: cem dias de omissão. Boletim ABIA, Rio de Janeiro, n. 11, p. 9-10, 2 jul. 1990.

GRANGEIRO, A.; SILVA, L. L. da; TEIXEIRA, P. R. Resposta à aids no Brasil: contribuições dos movimentos sociais e da reforma sanitária. Revista panamericana de salud publica, Washington, DC, v. 26, n. 1, p. 87-94, 2009.

GREEN, J. N. et al. Somos - Grupo de afirmação homossexual: 24 anos depois. Reflexões sobre os primeiros momentos do movimento homossexual no Brasil. Cadernos AEL, Campinas, v. 10, n. 18/19, p. 48-75, 2003. Mesa-redonda.

GUERRA, M. A. T. Política de controle da aids da Secretaria de Estado da Saúde de São Paulo, no período 1983-1992: a história contada por seus agentes. 1993. 280 f. Dissertação (Mestrado em Medicina Preventiva) Faculdadede Medicina, Universidade de São Paulo, São Paulo, 1993. HACKER, M. A. et al. Highly active antiretroviral therapy in Brazil: the challenge of universal access in a context of social inequality. Revista panamericana de salud publica, Washington, DC, v. 16, n. 2, p. 78-83, Aug. 2004.

HC INICIA este mês tratamento de aids. Folha de S. Paulo, São Paulo, 9 nov. 1983. Primeiro Caderno, Geral, p. 16.

IBGE. Censo demográfico 2010: características gerais da população, religião e pessoas com deficiência. Rio de Janeiro, 2012.

INFECÇÃO hospitalar. Folha de S. Paulo, 17 dez. 1985. Primeiro Caderno, Cidades, p. 18.

INSTITUTO NACIONAL DE CÂNCER (Brasil) - INCA. O câncer como problema de saúde pública. Rio de Janeiro, 2012.

INTERFERON teve seus poderes superestimados. Folha de S. Paulo, São Paulo, 4jun. 1983. Primeiro Caderno, Geral, p. 11.

ITALIAN GLOBAL HEALTH WATCH - OISG. From Alma Ata to the Global Fund: the history of international health policy. Social Medicine, New York, v. 3, n. 1, p. 36-48, Jan. 2008.

KORNIS, M. Ação católica brasileira. In: ABREU, A. A. de et al. (Coord.). Dicionário histórico-biográfico brasileiro: pós 1930. 2. ed. Rio de Janeiro: 
FGV, CPDOC, 2001. Disponível em: <http://www.fgv.br/cpdoc/acervo/ dicionarios/verbete-tematico/acao-catolica-brasileira-acb $>$. Acesso em: 10 jul. 2011.

LAMPIÃO DA ESQUINA. Rio de Janeiro: Lampião, 1978-1981. Disponível em:<http://www.grupodignidade.org.br/projetos/lampiao-da-esquina/>. Acesso em: 26 nov. 2011.

LANDIM, L. "Experiência militante": histórias das assim chamadas ONGs. Lusotopie, Aix-en-Provence, n. 1, p. 215-239, 2002.

LEIA o discurso do presidente. Folha de S. Paulo, São Paulo, 1 dez. 1991. Primeiro Caderno, Brasil, p. 4.

LIMA, S. C. V. S. Avaliação do processo de implementação da política de controle das DST/Aids no Maranhão. 2006. 258 f. Tese (Doutorado em Políticas Públicas) - Universidade Federal do Maranhão, São Luís, 2006.

LOYOLA, M. A. Medicamentos e saúde pública em tempos de aids: metamorfoses de uma política dependente. Ciência \& Saúde Coletiva, Rio de Janeiro, v. 13, p. 763-778, 2008. Suplemento.

MACIEL, L. R.; OLIVEIRA, M. L. W. de; GALLO, M. E. N. Memória e história da hanseníase no Brasil através de seus depoentes (1960-2000). Rio de Janeiro: Casa de Oswaldo Cruz, Departamento de Arquivo e Documentação, 2010.

MACRAE, E. A construção da igualdade: identidade sexual e política no Brasil da "abertura". Campinas: Ed. Unicamp, 1990.

MALTA, M.; BASTOS, F. I. Aids: prevenção e assistência. In: GIOVANELLA, L. et al. (Org.). Políticas e sistema de saúde no Brasil. Rio de Janeiro: Ed. Fiocruz, 2008. cap. 31, p. 1057-1088.

MARQUES, M. C. da C. A história de uma epidemia moderna: a emergência política da Aids/HIV no Brasil. São Carlos: Rima; Maringá: EDUEM, 2003.

MARTINS, L. Ação quer que SP pague droga anti-HIV. Folha de S. Paulo, São Paulo, 20 jul. 1996. Folha São Paulo, $3^{\circ}$ caderno, p. 4.

MARTINS, L.; TOSTA, W. Coquetel 'suaviza' falta de verba para aids. Folha de S. Paulo, São Paulo, 2 dez. 1997. Folha cotidiano, $3^{\circ}$ caderno, p. 1. MATONTI, F.; POUPEAU, F. Le capital militant. Essai de définition. Actes de la recherche en sciences sociales, Paris, n. 155, p. 4-11, 2004. Disponível 
em: $<$ http://www.cairn.info/revue-actes-de-la-recherche-en-sciencessociales-2004-5-page-4.htm>. Acesso em: 5 jun. 2012.

MAYER; J. M.; MONTEIRO; M. C.; ALDÉ, L. Andre Franco Montoro. In: ABREU, A. A. de et al. (Coord.). Dicionário histórico-biográfico brasileiro: pós 1930. 2. ed. Rio de Janeiro: FGV, CPDOC, 2001. Disponível em: $<$ http://www.fgv.br/cpdoc/acervo/dicionarios/verbete-biografico/andrefranco-montoro>. Acesso em: 10 jul. 2011.

MÉDICO diz que detentos internados não apresentam sintomas de aids. Folha de S. Paulo, São Paulo, 8 out. 1986. Primeiro Caderno, Cidades, p. 39.

MENDES, P. H. C. et al. Perfil dos pesquisadores bolsistas de produtividade científica em Medicina no CNPq, Brasil. Revista Brasileira de Educação Médica, Rio de Janeiro, v. 34, n. 4, p. 535-541, out./dez. 2010. MENDONÇA, P. M. E. de; ALVES, M. A.; CAMPOS, L. C. Empreendedorismo institucional na emergência do campo de políticas públicas em HIV/aids no Brasil. RAE eletrônica, São Paulo, v. 9, n. 1, jan./ jun. 2010. Disponível em: <http://www.scielo.br/scielo.php?script=sci arttext\&pid=S1676-56482010000100007\&lng=pt\&nrm=iso\&tlng=pt $>$. Acesso em: 6 out. 2010.

MONTEIRO, A. L. de O. A relação Estado e sociedade civil no processo de formulação e implementação de políticas públicas: análise do programa nacional de DST e Aids (1980-2006). 2006. 140 f. Dissertação (Mestrado em Gestão Social e Trabalho) - Faculdade de Economia, Administração, Contabilidade e Ciência da Informação e Documentação, Universidade de Brasília, Brasília, DF, 2006.

MOTT, L. [Comentários]. Boletim ABIA, Rio de Janeiro, n. 3, p. 12, 1 jul. 1988.

MOTT, L. A aids e os médicos no Brasil. Ciência e Cultura, São Paulo, v. 39, n. 1, p. 4-13, 1987.

MOTT, L. (Ed.). Boletim do Grupo Gay da Bahia: 1981-2005. Salvador: Ed. Grupo Gay da Bahia, 2011.

MOTT, L. Os candomblés da Bahia e a aids: pesquisa em 500 terreiros de Salvador. In: MOTT, L. R. de B; CERQUEIRA, M. (Org.). As religiões afrobrasileiras na luta contra a aids. Salvador: Centro Baiano Anti-Aids, 1998. p. 9-28. 
MOURA, M. Bernardo Galvão: a batalha contra a aids e outras lutas. Pesquisa Fapesp, São Paulo, v. 118, p. 10-15, dez. 2005.

MURRAY, L. R. et al. Strange bedfellows: The Catholic Church and brazilian national Aids program in the response to HIV/aids in Brazil. Social Science \& Medicine, [S.1.], v. 72, n. 6, p. 945-952, Mar. 2011. Disponível em:<https://www.ncbi.nlm.nih.gov/pmc/articles/PMC3080842/>. Acesso em: 2 out. 2012.

NASCIMENTO, D. R. do. As pestes do século XX: tuberculose e aids no Brasil, uma história comparada. Rio de Janeiro: Ed. Fiocruz, 2005.

NATALI, J. B. Há dez anos surgiram os sintomas do $1^{\circ}$ paciente de aids no Brasil. Folha de S. Paulo, São Paulo, 24 abr. 1990. Cidades, p. 5.

NO RIO, congresso de Hematologia debate a doença. Folha de S. Paulo, São Paulo, 9 set. 1985. Primeiro Caderno, Cidades, p. 13.

NUNN, A. The politics and history of Aids treatment in Brazil. New York: Springer, 2009.

O GAPA está precisando de uma sede. Boletim ABIA, Rio de Janeiro, n. 2, p. 8-12, 1 abr. 1988.

OKIE, S. Fighting HIV - Lessons from Brazil. The New England Journal of Medicine, Massachusetts,v. 354, n. 19, p. 1977-1981, May 11, 2006. Disponível em: <http://www.nejm.org/doi/full/10.1056/ NEJMpo68069\#t=article $>$. Acesso em: 5 out. 2010.

OLIVEIRA-CRUZ, V.; KOWALSKI, J.; MCPAKE, B. Viewpoint: the brazilian HIV/aids 'success story' - can others do it? Tropical Medicine and International Health, [S.1.], v. 9, n. 2, p. 292-297, Feb. 2004.

OLIVEIRA, M. F. de.; MORENO, F. V. Negociações comerciais internacionais e democracia: o contencioso Brasil X EUA das patentes farmacêuticas na OMC. DADOS - Revista de Ciências Sociais, Rio de Janeiro, v. 50, n. 1, p. 189-220, 2007.

OLIVEIRA, M. L. W. de. Participação em quatro décadas da política de controle da hanseníase no Brasil: acasos e determinações. Hansenologia Internationalis, Bauru, v. 33, n. 2, p. 45-50, 2008.

ONZE críticas a uma campanha desgovernada. Boletim ABIA, Rio de Janeiro, n. 2, p. 3-5, 1 abr. 1988. 
OPERÁRIOS podem ter trazido aids da África, diz médico. Folha de S. Paulo, São Paulo, 30 out. 1988. Cidades, p. C-5.

PAIM, J. S. Perspectivas do sistema público de saúde no Brasil. In: PAIM, J. S. Saúde: política e reforma sanitária. Salvador: Instituto de Saúde Coletiva, 2002. cap. 22, p. 271-294.

PAIM, J. S. Reforma sanitária brasileira: contribuição para a compreensão e crítica. Salvador: EDUFBA; Rio de Janeiro: Ed. Fiocruz, 2008.

PARKER, R. Building the foundations for the response to HIV/aids in Brazil: the development of HIV/aids policy, 1982-1996. Divulgação em Saúde para Debate, Rio de Janeiro, n. 27, p. 143-183, 2003.

PARKER, R. G. Civil society, political mobilization, and the impact of HIV scale-up on health systems in Brazil. Jaids-Journal of Acquired Immune Deficiency Syndromes, [S.1.], v. 52, p. s49-s51, Nov. 2009.

Disponível em: <https://www.ncbi.nlm.nih.gov/pmc/articles/ PMC3157647/>. Acesso em: 1 set. 2012.

PARKER, R.; TERTO JUNIOR, V. (Org.). Solidariedade: a ABIA na virada do milênio. Rio de Janeiro: ABIA, 2001.

PASTORAL pede clareza na campanha. Folha de S. Paulo, São Paulo, 26 fev. 1987. Primeiro Caderno, Cidades, p. A-16.

PEDROSA, C. Medicamentos e cidadania. Boletim ABIA, Rio de Janeiro, n. 35, p. [17], 19 jan. 1997.

PÉREZ-STABLE, E. J. Cubas response to the Hiv epidemic. American Journal of Public Health, Washington, DC, v. 81, n. 5, p. 563-567, May 1991. Disponível em: <http://ajph.aphapublications.org/doi/abs/10.2105/ AJPH.81.5.563>. Acesso em: 1 out. 2010.

PÉREZ-STABLE, E. J. La epidemia del SIDA en Cuba. Revista Latinoamericana De Psicologia, Bogotá, v. 24, n. 1/2, p. 71-84, 1992. Disponível em: <http://www.redalyc.org/articulo.oa?id=80524206>. Acesso em: 1 out. 2010.

PERLONGHER, N. O que é aids? São Paulo: Brasiliense, 1987.

PINELL, P. Algumas reflexões sobre as políticas de luta contra os flagelos sociais. In: PINELL, P. Análise sociológica das políticas de saúde. Rio de Janeiro: Ed. Fiocruz, 2010. cap. 7, p. 229-250. 
PINELL, P. et al. Une épidémie politique: la lutte contre le sida en France, 1981-1996. Paris: Presses universitaires de France, 2002.

PIOT, P.; SECK, A. M. C. International response to the HIV/aids epidemic: planning for success. Bulletin of the World Health Organization, [S.1.], v. 79, n. 12, p. 1106-1112, 2001. Disponível em: <http://apps.who.int/ iris/handle/10665/71042>. Acesso em: 10 out. 2010.

PONTOS para uma campanha de informação. Boletim ABIA, Rio de Janeiro, n. 2, p. 6-7, 1 abr. 1988.

PREVENÇÃO fatal. Boletim ABIA, Rio de Janeiro, n. 13, p. 1-4, 19 mar. 1991. PROGRAMA anti-aids contesta dados sobre contaminação de hemofílicos. Folha de S. Paulo, São Paulo, 30 dez. 1987. Primeiro Caderno, Cidades, p. A-14.

PROGRAMA NACIONAL DE DST E AIDS (Brasil). A Comissão Nacional de Aids: a presença do passado na construção do futuro. Brasília, DF, 2003 .

PROGRAMA NACIONAL DE DST E AIDS (Brasil). O remédio via justiça: um estudo sobre o acesso a novos medicamentos e exames em HIV/aids no Brasil por meio de ações judiciais. Brasília, DF, 2005.

QUEM SEMEIA pânico, colhe epidemia: caras e mascaras de uma campanha equivocada. Boletim ABIA, Rio de Janeiro, n. 2, p. 1-2, 1 abr. 1988.

RAI, M. A. et al. HIV/aids in Pakistan: the battle begins. Retrovirology, [S.l.], v. 4, n. 22, 2007. Disponível em: <https://retrovirology. biomedcentral.com/articles/10.1186/1742-4690-4-22>. Acesso em: 1 out. 2010.

RECOMENDAÇÕES sobre o uso de AZT no país. In: BRASIL. Ministério da Saúde. Comissão nacional de aids: 1986-1994. Brasília, DF, 1994a. p. 3738. Ata da $4^{\mathrm{a}}$ reunião da Comissão Nacional de Controle e Prevenção da Síndrome da Imunodeficiência Adquirida - CNCSIDA, 1987.

REDE BRASILEIRA DE SOLIDARIEDADE. Declaração dos direitos fundamentais da pessoa portadora do vírus da aids. Boletim ABIA, Rio de Janeiro, n. 9, p. 10-11, 19 nov. 1989. 
RÉDEAS curtas. Folha de S. Paulo, São Paulo, 26 abr. 1990. Primeiro caderno, Política, Painel, p. A-4.

RIBEIRO, E. de S. Gestão estadual do SUS: alternativas e adequação do sistema de informação para a política hospitalar. 2008. 98 f. Dissertação (Mestrado em Saúde Coletiva) - Faculdade de Ciências Médicas da Santa Casa de São Paulo, São Paulo, 2008.

ROCHA, P. “Doença dos homossexuais” atinge o país. Folha de S. Paulo, São Paulo, 8 jun. 1983. Primeiro Caderno, Geral, Interior, p. 15.

RODRIGUES, L. G. de M. [Introdução]. Boletim epidemiológico, Brasília, DF, ano 3, n. 7.p. 1, 1989.

RODRIGUES, M. T. A prostituição no Brasil contemporâneo: um trabalho como outro qualquer? Revista Katálysis, Florianópolis, v. 12, n. 1, p. 68-76, jan./jun. 2009. Disponível em: <http:/www.scielo.br/scielo. php?script=sci_arttext $\&$ pid $=$ S1414-49802009000100009\&nrm $=$ iso $>$. Acesso em: 5 set. 2012.

RODRIGUES, W. C. V.; SOLER, O. Licença compulsória do efavirens no Brasil em 2007: contextualização. Revista Panamericana de Salud Pública, Washington, DC, v. 26, n. 6, p. 553-559, 2009.

SANTOS, E. M. dos; REIS, A. C.; CRUZ, M. M. da. Análise do desempenho do sistema de monitoramento do programa de controle de DST/ Aids e hepatites virais (MONITORaids) como ferramenta de gestão: desafios e possibilidades. Revista Brasileira de Saúde Materno Infantil, Recife, v. 10, p. s173-s185, nov. 2010. Suplemento 1. Disponível em: <http://www.scielo.br/scielo.php?script=sci_arttext\&pid=S151938292010000500015\&nrm=iso >. Acesso em: 2 out. 2012.

SANTOS, L. A. de C.; MORAES, C.; COELHO, V. S. P. Os anos 80: politização do sangue. Physis: Revista de saúde coletiva, Rio de Janeiro, v. 2, n. 1, p. 107-149, 1992.

SANTOS, V. L. dos. Avaliação do grau de implementaçlão do Programa de DSTAids no distrito sanitário especial indígena de Mato Grosso do Sul - Distrito de Dourados. 2009. 106 f. Dissertação (Mestrado em Saúde Pública) - Escola Nacional de Saúde Pública Sergio Arouca, Fundação Oswaldo Cruz, Rio de Janeiro, 2009. 
SÃO NECESSÁRIOS mais R\$ 222 mi. Folha de S. Paulo, São Paulo, 23 dez. 1997. Folha São Paulo, $3^{\circ}$ caderno, p. 9.

SAÚDE recebe primeiro lote de AZT em abril. Folha de S. Paulo, São Paulo, 22 fev. 1991. Cotidiano, Quarto caderno, p. 3.

SBI: consolidação da infectologia no Brasil. In: SOCIEDADE Brasileira de Infectologia - 25 anos. São Paulo: SBI, 2005. p. 7-33.

SCALZO, F. Yes, nós falamos english. Veja, São Paulo, ano 30, n. 14, p. 124-128, 9 abr. 1997.

SCHEFFER, M. C. Aids, tecnologia e acesso sustentável a medicamentos: a incorporação dos anti-retrovirais no Sistema Único de Saúde. 2008. 243 f. Tese (Doutorado em Medicina Preventiva) - Faculdade de Medicina, Universidade de São Paulo, São Paulo, 2008.

SCHWARZSTEIN, J. Projeto do Banco Mundial: uma virada nas epidemias de Aids e DSTs no Brasil? Boletim ABIA, Rio de Janeiro, n. 19, p. 2-7, 19 maio 1993.

SE VOCÊ não se cuidar, a aids vai te pegar. Brasília, DF: Ministério da Saúde, 1991. 1 vídeo online (30 s), son, color. Disponível em: <http://www. aids.gov.br/index.php?q=midia/1991-se-voce-nao-se-cuidar-aids-vai-tepegar>. Acesso em: 22 nov. 2012.

SECRETÁRIA acha “calamitosa” situação sanitária do país. Folha de S. Paulo, São Paulo, 17 dez. 1986. Primeiro Caderno, Cidades, p. A-11.

SELIGMANN, M. et al. Concorde: MRC/ANRS randomised double-blind controlled trial of immediate and deferred zidovudine in symptom-free HIV infection. Lancet, [S.1.], v. 343, n. 8902, p. 871-881, Apr. 9, 1994.

SILVA, C. L. C. da. Ativismo, ajuda mútua e assistência: a atuação das organizações não-governamentais na luta contra a aids. 1999.344f. Tese (Doutorado em Sociologia) - Instituto de Filosofia e Ciências Sociais, Universidade Federal do Rio de Janeiro, Rio de Janeiro, 1999.

SILVA, J. M. D. Projeto Odô-Yá: uma experiência de educação e prevenção da epidemia de HIV/aids nas comunidades de terreiro. In: MOTT, L. R. de B.; CERQUEIRA, M. (Org.). As religiões afro-brasileiras na luta contra a Aids. Salvador: Centro Baiano Anti-Aids, 1998. p. 37-45. 
SILVA, L. L. da. Aids e homossexualidade em São Paulo. 1986. $204 \mathrm{f}$.

Dissertação (Mestrado em Ciências Sociais) - Pontifícia Universidade Católica de São Paulo, São Paulo, 1986.

SOUZA, C. de M. e. Dos estudos populacionais à saúde reprodutiva. In: BROOKE, N.; WITOSHYNSKY, M. (Org.). Os 40 anos da Fundação Ford no Brasil: uma parceria para a mudança social. São Paulo: Ed. USP; Rio de Janeiro: Fundação Ford, 2002. p. 131-164.

SOUZA, H. de. A aids hoje: possibilidades e desafios. Boletim ABIA, Rio de Janeiro, n. 35, p. [2-4], 19 jan. 1997.

SOUZA, H. de. A hora da cobrança. Boletim ABIA, Rio de Janeiro, n. 4, p. 5-7, 1 set. 1988.

SOUZA, H. Herbert de Souza (Betinho): entrevista. In: MEMÓRIA Roda Viva. São Paulo: Fundação Padre Anchieta, 14 dez. 1987. Entrevista concedida ao programa Roda Viva. Disponível em: <http://www.rodaviva. fapesp.br/materia/428/entrevistados/herbert_de_souza_betinho_1987. htm>. Acesso em: 3 jul. 2012.

SOUZA, L. E. P. F. D. S.; VIEIRA-DA-SILVA, L. M.; HARTZ, Z. M. de A. Conferência de consenso sobre a imagem-objetivo da descentralização da atenção à saúde no Brasil. In: HARTZ, Z. M. de A.; VIEIRA-DA-SILVA, L. M. (Org.). Avaliação em saúde: dos modelos teóricos à prática na avaliação de programas e sistemas de saúde. Salvador: EDUFBA; Rio de Janeiro: Fiocruz, 2005. p. 65-102.

STANISE, V. L. Avaliação do grau de institucionalização dos programas municipais de DST/HIV/aids na regional de saúde de Campinas - São Paulo, Brasil. 2008. 114 f. Dissertação (Mestrado em Saúde Pública) - Escola Nacional de Saúde Pública Sergio Arouca, Fundação Oswaldo Cruz, Rio de Janeiro, 2008.

SZWARCWALD, C. L. et al. A disseminação da epidemia da aids no Brasil, no período de 1987-1996: uma análise espacial. Cadernos de Saúde Pública, Rio de Janeiro, v. 16, p. 7-19, 2000. Suplemento 1.

TEIXEIRA refuta obrigatoriedade de teste sobre aids nos bancos de sangue. Folha de S. Paulo, São Paulo, 1 ago. 1985. Primeiro Caderno, Geral, p. 23 . 
TEIXEIRA, P. R. Políticas públicas em aids. In: PARKER, R. (Org.). Políticas, instituições e aids: enfrentando a epidemia no Brasil. Rio de Janeiro: J. Zahar, 1997. p. 43-68.

TEIXEIRA, P. R. et al. Debate aids. In: MEMÓRIA Roda Viva. São Paulo: Fundação Padre Anchieta, 19 jan. 1987. Debate com Paulo Roberto Teixeira, Maria Leide Wan Del Rey de Oliveira, Theodoro Israel Pluciennik, Caio Rosenthal, Valéria Petri, Samuel Koperstych, Vicente Amato Neto,Celso Carmo Mazza, Vera Escobar, Paulo César Bonfim e Enio Mainardi ocorrido no programa Roda Viva. Disponível em: <http:// www.rodaviva.fapesp.br/materia/211/entrevistados/debate_aids_1987. htm>. Acesso em: 7 set. 2012.

THE UNITED STATES PRESIDENT'S EMERGENCY PLAN FOR AIDS RELIEF - PEPFAR.Washington, DC, 2012. Disponível em: $<$ http://www. state.gov/documents/organization/29831.pdf>. Acesso em: 29 out. 2012.

THE WORLD BANK. Aids-SUS project (national Aids program - national health service). Washington, DC, Apr. 2010. Disponível em: < http:// documents.worldbank.org/curated/en/953641468228273906/BrazilAIDS-SUS-National-AIDS-Program-National-Health-Service-Project>. Acesso em: 29 out. 2012.

THE WORLD BANK. Brazil: Aids and STD control project. Washington, DC, Oct. 1993. Disponível em: <http://documents.worldbank.org/ curated/en/374541468740995928/Brazil-AIDS-and-STD-ControlProject>. Acesso em: 29 out. 2012.

THE WORLD BANK. Brazil: endemic disease control project. Washington, DC, June 1997. Disponível em: <http://documents. worldbank.org/curated/en/970241468227669253/Brazil-NortheastEndemic-Disease-Control-Project>. Acesso em: 29 out. 2012.

THE WORLD BANK. Brazil: first and second Aids and STD control projects.Washington, DC, Apr. 2004a. Disponível em: <http://documents. worldbank.org/curated/en/963411468744108959/Brazil-First-andSecond-AIDS-and-STD-Control-Projects>. Acesso em: 29 out. 2012. THE WORLD BANK. Loan $n^{\circ} 7901-B R$ (Brazil AIDS-SUS national AIDS program and national health service project): amendment to the loan agreement. Brasília, DF, 2014. 
THE WORLD BANK. Second Aids and STD control project. Washington, DC, May 2004b. Disponível em: <http://documents.worldbank.org/ curated/en/852271468770374857/Brazil-Second-AIDS-and-STD-ControlProject>. Acesso em: 29 out. 2012.

THE WORLD BANK. Third Aids and STD control project. Washington, DC, Dec. 2008. Disponível em: <http://documents.worldbank.org/curated/ en/641671468016787345/Brazil-Third-AIDS-and-STD-Control-Project>. Acesso em: 29 out. 2012.

UNAIDS. Ata da reunião realizada no dia 24 de outubro de 2001. Brasília, DF, 2001. Disponível em: $<$ http://www.unaids.org.br/quem_somos/2001/ GT\%2OUNAIDS\%2OBrasil\%20Outubro\%202001.pdf $>$. Acesso em: $7 \mathrm{dez}$. 2012.

VAZ, L. Adib Jatene é o mais cotado para assumir a vaga de Alceni. Folha de S. Paulo, São Paulo, 29 jan. 1992. Primeiro Caderno, Brasil, p. 7.

VERONESI, R. HIV-2. Folha de S. Paulo, São Paulo, 29 jun. 1988. Primeiro Caderno, Painel do Leitor, p. A-3. Disponível em: <https://acervo.folha. com.br/leitor.do?numero $=10279 \&$ keyword=Veronesi\&anchor $=4297942$ \&origem=busca>. Acesso em: 20 set. 2011.

VIEIRA-DA-SILVA, L. M.; PINELL, P. The genesis of collective health in Brazil. Sociology of Health \& Illness, [S.1.], v. 36, n. 3, p. 432-446, 2013.

VOEGTLI, M. Emergence, constitution et diversification d'une cause: processus de mobilisation, identités collectives et socialisations militantes dans l'espace associatif homosexuel et de lutte contre le sida en Suisse (1980-2005). 2009. 783 p. Thèse (Doctorat en Sociologie) - Faculté des Sciences Sociales e Politiques, Université de Lausanne, Lausanne, 2009.

WEBER, M. A política como vocação. Brasília, DF: Ed. UnB, 2003.

WEBER, M. Burocracia. In: WEBER, M. Ensaios de sociologia. 5. ed. Rio de Janeiro: Guanabara, 1982. cap. 8, p. 229-282.

WEBER, M. Conceitos sociológicos fundamentais. In: WEBER, M. Economia e sociedade: fundamentos da sociologia compreensiva. 3. ed. Brasília, DF: Ed. UnB, 1994.v. 1, p. 3-35. 
WELLCOME. Comunicado sobre o "Retrovir" (AZT) à classe médica e às autoridades sanitárias. Folha de S. Paulo, São Paulo, 26 nov. 1987. Primeiro Caderno, Política, p. A-5. 1 informe publicitário.

WORLD HEALTH ORGANIZATION - WHO. The 3 by 5 iniciative: treat three million people with HIV/aids by 2005. Geneva, 2012. Disponível em: <http://www.who.int/3by5/about/en/>. Acesso em: 29 out. 2012.

WORLD TRADE ORGANIZATION - WTO. Brazil - measures affecting patent protection: notification of mutually agreed solution. 19 July $2001 \mathrm{a}$. Disponível em: <https://docs.wto.org/dol2fe/Pages/FE_Search/FE_S_ Soo6.aspx?Query=(@Symbol=\%20wt/ds199/*)\&Language=ENGLISH\& Context=FomerScriptedSearch\&languageUIChanged=true $\#>$. Acesso em: 29 out. 2012.

WORLD TRADE ORGANIZATION - WTO. Brazil - measures affecting patent protection: request for consultations by the United States. 8 June 2000. Disponível em: <https://docs.wto.org/dol2fe/ Pages/FE_Search/FE_S_Soo6.aspx?Query=(@Symbol=\%2owt) ds199/*)\&Language=ENGLISH\&Context=FomerScriptedSearch\& languageUIChanged=true\#>. Acesso em: 29 out. 2012.

WORLD TRADE ORGANIZATION - WTO. Brazil - measures affecting patent protection: request for the establishment of a panel by the United States. 9 Jan. 2001b. Disponível em: <https://docs.wto.org/dol2fe/Pages/ FE_Search/FE_S_Soo6.aspx?Query=(@Symbol=\%20wt/ds199/*)\& Language=ENGLISH\&Context=FomerScriptedSearch\&language UIChanged=true\# $>$. Acesso em: 29 out. 2012.

WORLD TRADE ORGANIZATION - WTO. Declaration on the Trips agreement and public health: adopted on 14 november 2001.20 Nov. $2001 \mathrm{c}$. Disponível em: <https://www.wto.org/english/thewto_e/minist_e/ mino1_e/mindecl_trips_e.htm>.Acesso em: 29 out. 2012.

WU, Z. et al. Evolution of China's response to HIV/aids. Lancet, [S.l.], v. 369, p. 679-690, Feb. 24, 2007. Disponível em: <http://www.thelancet. com/journals/lancet/article/PIISO140-6736(07)60315-8/abstract>. Acesso em: 15 abr. 2009. 
WU, Z.; ROU, K.; CUI, H. The HIV/aids epidemic in China: history, current strategies and future challenges. Aids Education and Prevention, [S.l.], v. 16, n. 3, p. 7-17, June 2004. Disponível em: <http://web.bebscohost-com.ez10.periodicos.capes.gov.br/ehost/pdfviewer/ pdfviewer?vid=3\&sid=8bf697d1-edc5-4997-aoab19b2cac1c23c\%40sessionmgr103>. Acesso em: 15 abr. 2009. 


\section{APÊNDICE A \\ Percurso metodológico ${ }^{126}$}

Foi realizado um estudo sócio-histórico da gênese da política nacional de DST/Aids, no período compreendido entre 1981, ano dos primeiros relatos de caso em publicações científicas internacionais, e 2001, quando foi assinado o acordo entre Brasil e EUA no âmbito da Organização Mundial do Comércio acerca da licença compulsória de medicamentos, que assegurou a sustentabilidade da estratégia de acesso universal à terapia ARV.

Para reconstruir a gênese da política de controle da aids no país, foram analisadas as condições históricas para a sua emergência e reconstruída a dinâmica do espaço aids e da participação dos agentes dos campos burocrático, médico e político, bem como do espaço militante, ou associativo, e as relações entre eles.

Foram entrevistados os dirigentes da Política Nacional de DST/Aids entre 1986 e 2001, funcionários de carreira e/ou contratados do Ministério da Saúde do Brasil, relacionados direta ou indiretamente ao Programa Nacional de DST/Aids; o primeiro coordenador do Programa Estadual de São Paulo e um técnico desse programa; membros das principais organizações não governamentais, identificadas a partir das entrevistas com os dirigentes da Política Nacional de DST/Aids, e outros agentes identificados por meio da metodologia de bola de neve.

Foram realizadas 32 entrevistas em profundidade e uma consulta por e-mail, totalizando 33 agentes entrevistados. (Quadro 12) Foram analisados documentos do Ministério da Saúde e do governo federal Boletim Epidemiológico de Aids, portarias ministeriais, leis e decretos--, dos 
movimentos sociais (boletim do Grupo Gay da Bahia - GGB, boletim da Associação Brasileira Interdisciplinar de Aids - Abia, boletim de vacinas), o acervo disponibilizado online dos jornais Lampião da esquina, Folha de São Paulo, e O Estado de São Paulo, e da revista Veja, bem como foi realizada uma ampla revisão da produção bibliográfica e documental existente a respeito.

Todas as entrevistas foram realizadas pela autora e o tamanho da amostra foi delimitado pela saturação de informações.

Foram analisados os agentes e suas trajetórias ao interior do campo burocrático, dos movimentos sociais, do campo científico e do campo médico, bem como suas relações, suas posições e disposições, a partir dos seguintes indicadores (capitais/posições e tomadas de posição/opiniões, escolhas e ações, indicativas das disposições):

- Posição no espaço social, aferida através da profissão dos pais e dos avós e da trajetória profissional;

- Posição no espaço aids, aferida através da trajetória profissional ao interior do espaço aids;

- Indicadores de disposições políticas, filiação ou voto em partido político, participação no movimento sanitário, participação em movimentos profissionais e sociais, militância e participação em partidos;

- Indicadores de disposições sobre a organização do sistema de saúde, concepção sobre a imagem-objetivo do SUS, ${ }^{127}$ ocupação de postos no SUS;

Indicadores de disposições específicas sobre a aids: posição sobre a doença, posição sobre o componente preventivo, posição sobre as estratégias de tratamento, posição sobre o acesso universal aos medicamentos e sobre o termo homens que fazem sexo com homens (HSH). 
QUADRO 12 - Entrevistas realizadas

\begin{tabular}{|c|c|c|c|}
\hline Entrevistado & Relevância para a pesquisa & Cidade & $\begin{array}{l}\text { Data da } \\
\text { entrevista }\end{array}$ \\
\hline E1 & Sociólogo, coordenador do Programa Nacional de DST/Aids & São Paulo, SP & $21 / 06 / 2011$ \\
\hline E2 & Médica sanitarista Sesab/SMS Salvador & Salvador, BA & 06/07/2011 \\
\hline E3 & Advogada, fundadora Gapa-SP & São Paulo, SP & $20 / 06 / 2011$ \\
\hline E4 & Médico patologista, pesquisador da Fiocruz & Salvador, BA & $12 / 07 / 2011$ \\
\hline E5 & Socióloga, diretora do Grupo Pela Vidda-RJ, PN DST/Aids & São Paulo, SP & 04/05/2011 \\
\hline E6 & $\begin{array}{l}\text { Fórum de ONGs/Aids de São Paulo, diretor adjunto do Departamento de } \\
\text { DST, Aids e Hepatites virais-MS }\end{array}$ & Brasília, DF & 02/08/2011 \\
\hline E7 & Médico, coordenador do Programa Nacional de DST/Aids & $\begin{array}{l}\text { Rio de Janeiro, RJ } \\
\text { Skype } \\
\text { Skype }\end{array}$ & $\begin{array}{l}15 / 06 / 2011 \\
07 / 12 / 2011 \\
08 / 12 / 2011\end{array}$ \\
\hline E8 & Antropólogo, ex-integrante do Grupo Somos-SP, fundador Gapa-SP & Salvador, BA & $16 / 05 / 2011$ \\
\hline E9 & $\begin{array}{l}\text { Médico, epidemiologista, assessor do Programa Nacional de DST/Aids, } \\
\text { membro da Cnaids }\end{array}$ & São Paulo, SP & 05/05/2011 \\
\hline E10 & Médica Sanitarista, Secretária Nacional de Programas Especiais de Saúde & Salvador, BA & $14 / 07 / 2011$ \\
\hline E11 & $\begin{array}{l}\text { Médico dermatologista sanitário, Departamento de DST, Aids e Hepatites } \\
\text { virais-MS }\end{array}$ & Brasília, DF & 04/08/2011 \\
\hline $\mathrm{E} 12$ & $\begin{array}{l}\text { Administrador, fundador do Gapa-RS, coordenador do Programa DST/Aids } \\
\text { Porto Alegre }\end{array}$ & Porto Alegre, RS & $16 / 06 / 2011$ \\
\hline E13 & GIV, Técnico do Departamento de DST, Aids e Hepatites virais-MS & Brasília, DF & 02/08/2011 \\
\hline E14 & Administrador, fundador do Gapa-BA & Salvador, BA & $11 / 04 / 2011$ \\
\hline E15 & Secretária do Departamento de DST, Aids e Hepatites virais-MS & Brasília, DF & 04/08/2011 \\
\hline E16 & Médica epidemiologista, pesquisadora & Salvador, BA & 05/09/2011 \\
\hline E17 & Sociólogo, Departamento de DST, Aids e Hepatites virais-MS & Brasília, DF & 04/08/2011 \\
\hline E18 & $\begin{array}{l}\text { Matemático, fundador do Pela Vidda-SP, Membro Abia, Diretor GIV, } \\
\text { Pesquisador Nepaids }\end{array}$ & São Paulo, SP & $18 / 06 / 2011$ \\
\hline E19 & Médico, Comitê de Vacinas do Programa Nacional de DST/Aids & Salvador, BA & $13 / 05 / 2011$ \\
\hline $\mathrm{E} 20$ & Antropólogo, fundador do Grupo Gay da Bahia & Salvador, BA & $23 / 03 / 2011$ \\
\hline E21 & Economista, Departamento de DST, Aids e Hepatites virais-MS & Brasília, DF & 04/08/2011 \\
\hline $\mathrm{E} 22$ & Psicóloga, fundadora do Gapa-BA & Salvador, BA & $27 / 04 / 2011$ \\
\hline E23 & $\begin{array}{l}\text { Médica infectologista, coordenadora do Programa Estadual de DST/Aids } \\
\text { da Bahia }\end{array}$ & Salvador, BA & 07/06/2011 \\
\hline E24 & $\begin{array}{l}\text { Médica dermatologista, diretora da Divisão Nacional de Dermatologia } \\
\text { Sanitária à epoca }\end{array}$ & Correio eletrônico & $01 / 04 / 2012$ \\
\hline $\mathrm{E} 25$ & Antropólogo, realizou primeira pesquisa com usuários de drogas injetáveis & Salvador, BA & $26 / 05 / 2011$ \\
\hline E26 & Médico, $1^{\circ}$ coordenador do Programa Estadual de Aids de São Paulo & São Paulo, SP & 03/05/2011 \\
\hline E27 & Médico sanitarista, PN DST/Aids, Unaids & Brasília, DF & 03/08/2011 \\
\hline E28 & $\begin{array}{l}\text { Tecnólogo em Processamento de dados, Departamento de DST, Aids e } \\
\text { Hepatites virais-MS }\end{array}$ & Brasília, DF & $04 / 08 / 2011$ \\
\hline
\end{tabular}




\begin{tabular}{|c|c|c|c|}
\hline Entrevistado & Relevância para a pesquisa & Cidade & $\begin{array}{l}\text { Data da } \\
\text { entrevista }\end{array}$ \\
\hline E29 & Psicóloga, Fundadora da Abia & Rio de Janeiro, RJ & $15 / 06 / 2011$ \\
\hline E30 & $\begin{array}{l}\text { Médica infectologista, Programa Nacional de DST/Aids, Diretora Ipec/ } \\
\text { Fiocruz }\end{array}$ & Rio de Janeiro, RJ & $14 / 06 / 2011$ \\
\hline E31 & Médica dermatologista, identificou os primeiros casos de Aids no país & São Paulo, SP & $20 / 06 / 2011$ \\
\hline E32 & Psicóloga, pesquisadora e fundadora do Nepaids & São Paulo, SP & $21 / 06 / 2011$ \\
\hline E33 & Psicólogo, diretor da Abia & Rio de Janeiro, RJ & $15 / 06 / 2011$ \\
\hline
\end{tabular}

Nesse sentido, as entrevistas realizadas com agentes situados em lugares diferentes do espaço aids - médico, técnico do ministério, representante de ONG - permitiram o mapeamento das posições, e a identificação de temas polêmicos cujas tomadas de posição implicavam em diferenças ao interior do espaço.

A classificação dos agentes, de acordo com a inserção nos campos sociais, foi realizada de acordo com indicadores de volume de capital científico, burocrático, militante e político:

- Indicadores de capital científico (pós-graduação, publicações);

- Indicadores de capital burocrático (cargos ocupados e recursos mobilizados);

- Indicadores de capital político (participação em partidos políticos, participação em cargos eletivos e ocupação de cargos administrativos que resultam de articulações especificamente políticas);

- Indicadores de capital militante (participação em movimentos sociais - movimento estudantil, movimento sanitário, movimento pela redemocratização, movimentos pela saúde, e em associações específicas de luta contra a aids).

A análise do volume dos diferentes tipos de capital foi realizada para dois períodos distintos: a gênese da política (1983-1986) e o último ano do período estudado (2001). Para a análise do volume de capital burocrático, político e militante foram usados os mesmos critérios para os dois períodos, mas para a análise do volume de capital científico, os critérios foram ajustados à situação do campo científico do referido período, a partir do perfil 
dos pesquisadores bolsistas de produtividade científica do CNPq das áreas de Saúde Coletiva em 2002 (BARATA; GOLDBAUM, 2003) e de Medicina para o triênio 2005-2007. (MENDES et al., 2010) (Quadros 13 e 14)

Sempre que houve necessidade de esclarecimentos e/ou complementações foram utilizados recursos como correio eletrônico e contato telefônico ou Skype. As informações foram confirmadas e complementadas através de consultas a documentos do Ministério da Saúde e seus órgãos, programas e anais dos eventos da área, informações disponíveis em bases como currículo Lattes e outras disponíveis na internet.

Foi feita uma síntese dessas informações a partir do referencial teórico utilizado, buscando reunir elementos capazes de caracterizar a gênese da política nacional de controle da aids, o papel do campo burocrático e a sua relação com o espaço aids, mais especificamente as ONGs.

O projeto foi submetido ao Comitê de Ética em Pesquisa do Instituto de Saúde Coletiva da UFBA e todos os entrevistados assinaram o termo de consentimento informado e manifestaram o acordo com a divulgação do seu nome. Esta estratégia foi adotada por se tratar de informações relacionadas ao exercício de cargos ou posições públicas. O único caso em que não foi possível o contato pessoal, o consentimento escrito e informado do entrevistado foi encaminhado através de correio eletrônico. 
QUADRO 13-Critérios de análise da composição das diferentes espécies de capital no período da gênese do espaço aids no Brasil (1981 a 1986)*

\begin{tabular}{|c|c|c|c|c|}
\hline $\begin{array}{l}\text { Volume do capital } \\
\text { Tipo de Capital }\end{array}$ & Muito Alto (AA) & Alto (A) & Médio (M) & Pequeno (P) \\
\hline Científico & $\begin{array}{l}\text { Reconhecimento } \\
\text { internacional } \\
\text { Prêmios internacionais. } \\
\text { Coordenar projetos } \\
\text { de pesquisa ou } \\
\text { estruturantes financiados } \\
\text { por organismos } \\
\text { internacionais }\end{array}$ & $\begin{array}{l}\text { Reconhecimento } \\
\text { nacional } \\
\text { Prof. Titular } \\
\text { Coordenar projetos } \\
\text { financiados por } \\
\text { organismos nacionais }\end{array}$ & $\begin{array}{l}\text { Reconhecimento local } \\
\text { Doutorado } \\
\text { Participar de projetos de } \\
\text { pesquisa relacionados à } \\
\text { resposta à epidemia }\end{array}$ & Mestrado \\
\hline $\begin{array}{l}\text { Burocrático } \\
\text { Ocupação de } \\
\text { cargos técnicos, }\end{array}$ & $\begin{array}{l}\text { Cargos de direção em org. } \\
\text { Intern. (Unaids, OPAS, } \\
\text { OMS) } \\
\text { Dirigentes do Programa } \\
\text { Nacional de DST/Aids ou } \\
\text { cargos superiores com } \\
\text { interferência sobre a } \\
\text { política de aids }\end{array}$ & $\begin{array}{l}\text { Direção de Programas } \\
\text { Estaduais } \\
\text { Técnicos do Programa } \\
\text { Nacional de DST/Aids } \\
\text { Participação nas } \\
\text { reuniões para definição } \\
\text { da política do MS }\end{array}$ & $\begin{array}{l}\text { Cargos de direção } \\
\text { intermediários em } \\
\text { Secretarias Municipais } \\
\text { de Saúde } \\
\text { (programas municipais) } \\
\text { Técnicos de programas } \\
\text { estaduais }\end{array}$ & $\begin{array}{l}\text { Cargos técnicos } \\
\text { (assessor, consultor) }\end{array}$ \\
\hline $\begin{array}{l}\text { Político } \\
\text { Ocupação } \\
\text { de cargos } \\
\text { administrativos } \\
\text { que resultam } \\
\text { em articulações } \\
\text { especificamente } \\
\text { políticas }\end{array}$ & $\begin{array}{l}\text { Ministro da Saúde, } \\
\text { Presidentes de Agências }\end{array}$ & $\begin{array}{l}\text { Secretários Estaduais } \\
\text { de Saúde }\end{array}$ & $\begin{array}{l}\text { Secretários Municipais } \\
\text { de Saúde }\end{array}$ & $\begin{array}{l}\text { Outros cargos técnicos } \\
\text { de indicação política. }\end{array}$ \\
\hline $\begin{array}{l}\text { Participação em } \\
\text { Partidos Políticos }\end{array}$ & Dirigente Nacional & $\begin{array}{l}\text { Dirigente estadual de } \\
\text { Partido político }\end{array}$ & $\begin{array}{l}\text { Dirigente municipal de } \\
\text { partidos políticos }\end{array}$ & Filiado a partido político \\
\hline $\begin{array}{l}\text { Participação em } \\
\text { cargos eletivos }\end{array}$ & $\begin{array}{l}\text { Senador, Deputado } \\
\text { federal }\end{array}$ & Deputado estadual & Vereador & \\
\hline $\begin{array}{l}\text { Militante } \\
\text { Lideranças } \\
\text { profissionais e } \\
\text { populares }\end{array}$ & $\begin{array}{l}\text { Dirigente com liderança } \\
\text { carismática capaz de } \\
\text { mobilizar e aglutinar } \\
\text { (elevado capital } \\
\text { simbólico) }\end{array}$ & $\begin{array}{l}\text { Dirigente de ONGs ou } \\
\text { movimentos sociais }\end{array}$ & $\begin{array}{l}\text { Quadro intermediário } \\
\text { de ONGs ou movimentos } \\
\text { sociais }\end{array}$ & $\begin{array}{l}\text { Militantes de ONGs ou } \\
\text { movimentos sociais }\end{array}$ \\
\hline
\end{tabular}

Notas:

*Adaptado de VIEIRA-DA-SILVA, L. M. et al. O espaço da saúde coletiva. Salvador: [s.n.], 2010. Relatório de pesquisa.

**Aferido a partir de cargos ocupados, considerando que a ocupação de cargo técnico requer títulos (capital cultural adquirido) adequados ao cargo em questão. 
QUADRO 14 - Critérios de análise da composição do capital científico em 2001

\begin{tabular}{|c|c|c|c|c|}
\hline $\begin{array}{l}\text { Volume do capital } \\
\text { Tipo de Capital }\end{array}$ & Muito Alto (AA) & Alto (A) & Médio (M) & Pequeno (P) \\
\hline Científico & $\begin{array}{l}\text { Doutorado } \\
\text { Produção compatível } \\
\text { com o perfil de bolsista } \\
\text { CNPq 1A } \\
\text { Área Saúde Coletiva - } 13 \\
\text { artigos nos últimos } 3 \\
\text { anos (6 em revista A) } \\
\text { Área Medicina - } 20 \\
\text { artigos em revista A nos } \\
\text { últimos } 3 \text { anos }\end{array}$ & $\begin{array}{l}\text { Doutorado } \\
\text { Produção compatível } \\
\text { com o perfil de bolsista } \\
\text { CNPq } 1 \mathrm{~B} \mathrm{e} 1 \mathrm{C} \\
\text { Área Saúde Coletiva - } 10 \\
\text { artigos nos últimos } 3 \\
\text { anos ( } 6 \text { em revista } A \text { ) } \\
\text { Área Medicina - } 16 \\
\text { artigos em revista A nos } \\
\text { últimos } 3 \text { anos }\end{array}$ & $\begin{array}{l}\text { Doutorado } \\
\text { Produção compatível } \\
\text { com o perfil de bolsista } \\
\text { CNPq } 2 \\
\text { Área Saúde Coletiva - } 9 \\
\text { artigos nos últimos } 3 \\
\text { anos ( } 3 \text { em revista A) } \\
\text { Área Medicina - } 9 \\
\text { artigos em revista A nos } \\
\text { últimos } 3 \text { anos }\end{array}$ & $\begin{array}{l}\text { Doutorado } \\
\text { Integrar equipe de } \\
\text { projeto de pesquisa }\end{array}$ \\
\hline
\end{tabular}




\section{Roteiro para entrevistas em profundidade}

Fale de sua trajetória social: onde nasceu, onde seus pais trabalhavam?

Fale da sua trajetória profissional - onde estudou, formação inicial, escolhas e justificativas.

Qual é e como começou a sua relação com a aids?

Fale sobre como surgiu a política de controle da aids no Brasil.

Qual sua participação e quem foram os principais agentes responsáveis - movimentos sociais, categorias profissionais, instituições, técnicos pelo seu surgimento?

Para você o que é a aids?

Quais as principais estratégias para o enfrentamento da epidemia?

Quais são os principais problemas relacionados ao controle da epidemia da aids hoje?

Na sua opinião, o que é o SUS? Quais seus objetivos?

O que é a reforma sanitária? Quais seus objetivos?

O que significam o SUS e a reforma sanitária para a política de aids no país?

Quais são seus objetivos profissionais hoje? Quais seus objetivos na luta contra a aids hoje?

Você se sente realizado trabalhando/militando na área da aids? Por que deixou de trabalhar/militar na área de aids? 


\section{APÊNDICE B \\ Trajetórias dos principais agentes \\ estudados}

Alexandre Grangeiro

Nasceu em Bragança Paulista, São Paulo. Seu pai era dono de um expresso rodoviário, que tinha uma das sedes na cidade onde nasceu. A mãe não trabalhava, acompanhava o pai, “como uma boa esposa”. O avô paterno também era comerciante na região. A família não tinha prática religiosa, mas acreditava em Deus. Ainda no colégio, se envolveu no movimento estudantil, que, na sua opinião, "era uma desculpa para se ter um ativismo político" ${ }^{128}$ Participou da Convergência Socialista, se envolveu na formação do PT e depois se distanciou. Alexandre cursou o ensino médio em escola pública e, em 1987, iniciou o curso de Ciências Sociais na PUC-SP. Diz que não sabe explicar por que escolheu fazer Sociologia, relata que ficava entre o tentar entender o indivíduo e tentar entender o coletivo. Seu envolvimento com a área da saúde começou praticamente ao mesmo tempo que o curso de graduação, atuando como estagiário em um projeto de cooperação para os 60 anos da hanseníase no Brasil, na Grande São Paulo, que resgatava o arquivo histórico sobre hanseníase do Instituto de Saúde de São Paulo. Permaneceu como estagiário na Divisão de Hansenologia e Dermatologia Sanitária (DHDS) do Instituto de Saúde. Com a epidemia da aids, Alexandre foi para o Disque aids, tendo a função de atender às chamadas telefônicas e dar orientação. Inicialmente eram apenas dois turnos, mas à medida que a demanda do serviço se ampliou, sua carga horária dedicada ao Disque aids também foi aumentando. Quando José Aristodemo Pinotti assumiu a SES-SP, Alexandre foi, seguindo Paulo

128 Declaração obtida em entrevista concedida à autora. 
Roberto Teixeira, que foi destituído do cargo de Diretor da DHDS, para a Vigilância Epidemiológica na SES-SP. Retornou ao Programa de Aids quando Mário Covas assumiu o governo de São Paulo e Paulo Roberto Teixeira voltou a coordenar o CRT de DST/Aids, ficando na prevenção e, mais tarde, na direção adjunta. Foi para o Programa Nacional a convite de Pedro Chequer, quando este era coordenador. Lá, iria trabalhar na Vigilância Epidemiológica, mas terminou indo para a área de planejamento e avaliação, o que considerou mais interessante por trabalhar com estados e municípios, chegando a assumir a direção do setor. Quando Paulo Teixeira assumiu o Programa Nacional, em 2000, Alexandre ficou como seu adjunto. Entre março de 2003 e agosto de 2004, Alexandre foi o diretor do Programa Nacional. Retornou para São Paulo, onde permaneceu como assessor entre 2005 e 2007, quando assumiu a direção do Instituto de Saúde. Após sua saída, permaneceu como pesquisador no Departamento de Medicina Preventiva da USP. Alexandre se sente coparticipe da resposta à epidemia da aids no Brasil.

\section{Referências}

BARROS, S. G. de. A política nacional de luta contra a aids e o espaço aids no Brasil. 2013.274 f. Tese (Doutorado em Saúde Pública) - Instituto de Saúde Coletiva, Universidade Federal da Bahia, Salvador, 2013.

FRANÇA, M. S. J. Ciência em tempos de aids: uma análise da resposta pioneira de São Paulo à epidemia. 2008. 195 f. Tese (Doutorado em História da Ciência) - Pontifícia Universidade Católica de São Paulo, São Paulo, 2008.

GRANGEIRO, A. Currículo do sistema Currículo Lattes. [S.l.], 2011.

Disponível em: $<$ http://buscatextual.cnpq.br/buscatextual/visualizacv. do?id=K4780367P1>. Acesso em: 18 maio 2011. 
Nasceu em Niterói, Rio de Janeiro. Sua mãe era professora do Estado na década de 1960. Seu pai era funcionário concursado do Banco do Brasil, formou-se em Direito, mas só começou a exercer a profissão de advogado quando se aposentou do banco. À época da pesquisa, seu pai, aos 76 anos, exercia a advocacia. $O$ avô paterno era chefe da oficina mecânica do IBGE e o materno, um pequeno comerciante, proprietário de um armazém que comercializava tecidos e produtos alimentícios. De família católica, Ana considera como única atividade política que teve a sua participação no movimento franciscano, que frequentou dos 14 aos 17 anos. Sempre votou no PT. Não gostava do PC do B, que considerava uma "turma irresponsável, faziam uma boa política, mas não eram bons alunos". ${ }^{129}$ Sempre admirou as pessoas com bom desenvolvimento acadêmico, a meritocracia. Cursou o ensino médio no Colégio 2 de Julho, em Salvador. E, em virtude da sua formação cristã, ainda que hoje se declare não católica, a escolha da profissão foi pautada na vontade de querer mudar o mundo sendo médica. Fez Medicina na UFBA, entre 1980-1985, em seguida, fez residência em Medicina Social (1986-1987) na mesma instituição. Sua busca por uma disciplina de excelência, na Faculdade de Medicina da UFBA, a aproximou da Saúde Coletiva, pois os departamentos de excelência eram a imunologia, a patologia, vinculadas à Fiocruz, e a Medicina Preventiva. A decisão veio quando cursou a Disciplina de Saúde Pública e Medidas de Profilaxia, no sexto ano da graduação, pela "possibilidade de correlacionar as condições de vida e saúde com aspectos do contexto político, econômico e social". ${ }^{29}$ Chegou a trabalhar como médica clínica durante um período muito curto - cerca de dois meses -, mas "levava muito tempo conversando com pacientes e não pedia exames”. ${ }^{129}$ Fez concurso para Médico 
Sanitarista na Secretaria de Saúde do Estado da Bahia (SESAB), permanecendo de 1989 a 1992 nessa função, quando fez concurso para médica. Entre 1993 e 1996, foi também assessora técnica da Secretaria Municipal de Saúde de Salvador. Sua relação com a aids se deu quando participou da elaboração do Plano trienal de combate à DST/Aids (1993-1995) do estado da Bahia, indicada pela Diretora da Assessoria de Planejamento, onde era lotada, atuando junto a técnicos do Ministério da Saúde na elaboração do POA relativo ao $1^{\circ}$ acordo de empréstimo do banco Mundial, o AIDS I. Continuou no quadro da Secretaria, mas cedida ao Instituto de Saúde Coletiva da UFBA como docente da Residência Multiprofissional em Medicina Social no período de 1997 até 2009. Foi docente do curso de Medicina da Universidade Estadual de Feira de Santana (UEFS) no período de 2006 a 2009. Desde 2009, quando foi aprovada em concurso público, é professora adjunto do ISC/UFBA. Ana Luiza não continuou trabalhando na área de HIV/aids, acha que cumpriu a sua obrigação, o seu dever profissional, mas que "não teria vontade de trabalhar com uma política mais específica"129 na sua vida profissional.

\section{Referências}

BARROS, S. G. de. A política nacional de luta contra a aids e o espaço aids no Brasil. 2013. 274 f. Tese (Doutorado em Saúde Pública) - Instituto de Saúde Coletiva, Universidade Federal da Bahia, Salvador, 2013.

VILASBÔAS, A. L. Q. Currículo do sistema Currículo Lattes. [S.l.], 2011. Disponível em: $<$ http://buscatextual.cnpq.br/buscatextual/visualizacv. do?id=K4787176H6>. Acesso em: 18 maio 2011. 


\section{Áurea Celeste da Silva Abbade}

Nasceu em 10 de dezembro de 1947. Sua mãe trabalhava na Maternidade Pro Mater Paulista, mas desde seus oito anos a mesma estava em auxílio doença. Seu pai faleceu quando ainda tinha dois meses de idade. $\mathrm{O}$ avô paterno era mascate e o materno fabricante de vinho. Conviveu com diversas tradições religiosas: evangélica, católica, com as diversas religiões afro-brasileiras. Gostava da igreja católica, mas se sentia mais próxima do centro espírita que frequenta. Fez o ensino médio no Liceu Eduardo Prado, um colégio particular, de freiras, onde era bolsista. Queria fazer medicina, mas terminou se formando em Direito na PUC-SP. Durante a faculdade, trabalhava com venda direta (Avon, Christian Gray) ou fazendo cestas de Natal. Refere que como entrou na faculdade já no período do AI-5, não se envolveu no movimento estudantil. Formada, trabalhou em um escritório de advocacia até 1972, quando montou seu escritório próprio com um colega, mas desde a década de 1990 começou a trabalhar sozinha. É filiada ao PPS, mas votou em Lula e Erundina. Considera que não é possível conciliar o Gapa com militância política. Foi como advogada da assistente social do Hospital Emílio Ribas, Otília Simões Janeiro Gonçalves, que casualmente participou da reunião inicial de formação do Gapa. Otília estava precisando de orientações profissionais de Áurea, e como teria uma reunião, agendou com a advogada no próprio hospital. Quando chegou ao hospital, estava havendo uma reunião sobre aids. Ela participou, mas fora do círculo formado pelos participantes, pois havia chegado depois. As pessoas estavam desesperadas. No final da reunião passaram uma lista para saber dos presentes quem poderia ajudar, em que horário etc. Quando lhe entregaram a lista, pediu desculpas e disse que estava "fora da rodinha" e foi questionada se não poderia ajudar. As reuniões seriam realizadas nos sábados às $15 \mathrm{~h}$, horário em que ela podia. Áurea tornou-se fundadora do Gapa, criou o primeiro serviço de apoio 
jurídico a portadores do vírus, participou da elaboração do primeiro cartaz de prevenção à aids produzido no Brasil “Transe numa boa”, redigiu o documento que deu origem à Lei 7.670, de 1989, que libera o FGTS e o PIS/Pasep para portadores do vírus, foi coordenadora do Projeto Previna do Ministério da Saúde (1989), foi advogada da primeira reclamação trabalhista no Brasil que reintegrou um portador de HIV/aids ao trabalho, da primeira medida cautelar contra convênio médico, obrigando a prestar assistência ambulatorial e hospitalar ao portador de HIV/aids e a propor ação contra o Estado para obtenção da terapia combinada para portador de HIV/aids. Atualmente é presidente do Gapa-SP, sente-se realizada em termos pois diz que cada dia faltam mais coisas e que faltam novas lideranças.

\section{Referências}

ABBADE, Á. C. da S.; BAIÃO, F. (Org.). 100 nomes que fizeram a história da luta contra a aids no Brasil. São Paulo: GAPA BR SP, 201O. p. 19.

BARROS, S. G. de. A política nacional de luta contra a aids e o espaço aids no Brasil. 2013. 274 f. Tese (Doutorado em Saúde Pública) - Instituto de Saúde Coletiva, Universidade Federal da Bahia, Salvador, 2013. 
Nasceu em 3 de maio de 1945, em Salvador, Bahia. Seu pai era professor e mantinha um pensionato para jovens de outras cidades que iam estudar em Salvador no Colégio Sofia Costa Pinto. Sua mãe era dona de casa. Cursou o ensino médio no Colégio Central (público). Resolveu fazer medicina porque sempre quis pesquisar e resolver os problemas das pessoas. Fez teste vocacional e o resultado apontava medicina e administração. Foi membro do Partido Comunista. Cursou medicina entre 1964-1969 na UFBA. Fez Residência (1970-1971) e mestrado (1971-1974) em Anatomia Patológica na mesma instituição. Fez o doutorado em Imunologia na Universidade de Genebra, Suiça, sob orientação de Paul Henri Lambert. No mestrado e doutorado Galvão trabalhou com Tripanossomose africana. Quando retornou ao Brasil, foi trabalhar na Fiocruz no Rio de Janeiro, pois a instituição ainda não tinha um centro de pesquisa na Bahia. Conseguiu um grant junto à OMS para a implantação de um laboratório de doenças infecciosas e parasitárias, que se tornou mais tarde o Departamento de Imunologia do Instituto Oswaldo Cruz. Em 1982, mobilizado pelo contato com um jovem portador da doença e considerando a possibilidade de disseminação da aids no país devido a suas características - transmitida pelo sexo, pelo sangue - e a missão da Fiocruz de responder questões de saúde pública, iniciou, com Claudio Ribeiro, os trabalhos sobre aids na Fiocruz. Adaptou a técnica da imunofluorescência usada para Chagas para identificação do anticorpo para HIV, que possibilitou a implantação das triagens nos bancos de sangue do país. Coordenou a equipe que isolou pela primeira vez o HIV no Brasil, em 1987. Implantou o primeiro laboratório $\mathrm{P}_{3}$ do Brasil (Laboratório Avançado de Saúde Pública), no Centro de Pesquisas Gonçalo Muniz/Fiocruz, em Salvador. É pesquisador da Fiocruz desde 1979 e bolsista de produtividade 1B do Conselho Nacional de Desenvolvimento Científico e Tecnológico 
(CNPq), tendo parte de sua carga horária cedida à Fundação Bahiana para o Desenvolvimento da Ciência (FBDC), através de convênio. Membro da Academia Baiana de Medicina (2002), Membro da American Association for the Advencement of Science (2000). Consultor Ad hoc do CNPq (1979), coordenador de diversos projetos de pesquisa junto ao CNPq e ao Programa Nacional de DST/Aids, consultor da OMS (1983). Revisor do periódico Memórias da Fundação Oswaldo Cruz desde 1981, integrando seu corpo editorial a partir de 1988. É também revisor de diversos periódicos nacionais e internacionais como Revista da Sociedade Brasileira de Medicina Tropical (2005), Journal of Medical Virology (2008), Revista do Instituto de Medicina Tropical de São Paulo (2009), Journal of Clinical Virology (2009), The Brazilian Journal of Infectious Diseases (2009), BMC Public Health (2009), Human Immunology (2010), Journal of Virological Methods (2010) e Revista Panamericana de Salud Pública (2010) e a partir de 2008, passou a compor o corpo editorial da Revista Brasileira de Neurologia e Psiquiatria. Recebeu o Prêmio Etienne Gorjux, da Faculdade de Medicina da Universidade de Genebra, Suiça (1977), VI Prêmio Hélio Gelli Pereira da Sociedade Brasileira de Virologia (2002), a medalha Tomé de Souza, da Câmara Municipal de Salvador (2002), entre outros. Foi eleito membro do Conselho de Sociedade Internacional de Sida/Aids para os biênios 1988-1990 e 1990-1992 e do Conselho da Sociedade Internacional de Retrovirologia em 1995. Mais de 150 artigos publicados.

\section{Referências}

ABBADE, Á. C. da S.; BAIÃO, F. (Org.). 100 nomes que fizeram a história da luta contra a aids no Brasil. São Paulo: GAPA BR SP, 2010. p. 23.

BARROS, S. G. de. A política nacional de luta contra a aids e o espaço aids no Brasil.2013.274 f. Tese (Doutorado em Saúde Pública) - Instituto de Saúde Coletiva, Universidade Federal da Bahia, Salvador, 2013.

CASTRO FILHO, B. G. Currículo do sistema Currículo Lattes. [S.1.], 2011. Disponível em: $<$ http://buscatextual.cnpq.br/buscatextual/visualizacv. do?id=K4783667A8>. Acesso em: 17 maio 2011. 
GARCIA, M. A evolução do estudo da aids, por um de seus codescobridores. Instituto Oswaldo Cruz, Rio de Janeiro, 25 maio 2011. Disponível em: <http://www.fiocruz.br/ioc/cgi/cgilua.exe/sys/start. htm?infoid=1174\&sid=32>. Acesso em: 17 nov. 2011.

MOURA, M. Bernardo Galvão: a batalha contra a aids e outras lutas. Pesquisa Fapesp, São Paulo, v. 118, p. 10-15, dez. 2005. 
Nasceu em São João do Meriti, no Rio de Janeiro. A família, natural do Rio Grande do Norte, foi morar em São João do Meriti porque o pai, militar da Marinha, havia sido transferido. Sua mãe era dona de casa. A família sempre quis retornar para Natal, o que aconteceu em 1983, quando iniciou o curso de Ciências Sociais na UFRN, pois queria "entender porque algumas coisas aconteciam”. ${ }^{130}$ No segundo grau, havia feito curso técnico em contabilidade e durante os dois primeiros anos da faculdade trabalhou nas lojas Americanas, de onde saiu já como supervisora de vendas para ser bolsista de iniciação científica, em um projeto que visava organizar uma proposta de conteúdo para o ensino de ciência de $1^{\mathrm{a}}$ a $4^{\mathrm{a}}$ series do primeiro grau, o que foi reprovado pela família, mas para ela significava um investimento na profissão. Cursou uma disciplina de gênero e pela primeira vez se aproximou do universo da homossexualidade quando decidiu trabalhar com prostituição como tema do trabalho da disciplina e foi orientada por um amigo a realizar a pesquisa em um bar gay frequentado por mulheres e onde havia comércio sexual. Nesse período, acompanhou a formação do PT, participou do movimento pelas diretas já e participou de uma chapa que foi eleita para o Diretório Acadêmico, mas não chegou a assumir porque, em 1986, mudou-se para o Rio de Janeiro outra vez, onde concluiu o curso na UFRJ. No Rio conseguiu uma bolsa de apoio técnico, ficando vinculada ao Núcleo de Estudos e Pesquisas sobre a Infância (Nepi). Participou da campanha de Fernando Gabeira para governador do Rio. Ao final da graduação, resolveu seguir a vida acadêmica e em 1989 inscreveu-se no mestrado na própria UFRJ, quando também foi selecionada como docente para a disciplina de Sociologia do curso de jornalismo da Faculdade da Cidade. Na dissertação de mestrado procurou reu- 
nir sexualidade e política através do caso do grupo gay carioca Triângulo Rosa. Foi quando se aproximou do tema da aids. Entre 1989 e 1990, trabalhou em uma das primeiras pesquisas sobre aids no IMS, coordenada por Maria Andreia Loyola. A partir de 1991, começou a se aproximar do Grupo Pela Vidda, tendo aceito um convite para trabalhar no grupo em 1992. Com o doutorado, se afastou da direção do grupo em 1995, mantendo uma participação mais pontual. O doutorado também foi cursado na UFRJ (1995-1999), tendo como tema "Ativismo, ajuda mútua e assistência: a atuação das organizações não governamentais na luta contra a aids”. Tem atuado como docente em diversas instituições particulares, sendo o principal vínculo com a Universidade Estácio de Sá, onde ficou entre 1993-2000. Em 2001, assumiu a Chefia da Unidade de Articulação com ONGs do Programa Nacional de DST/Aids, onde permaneceu até 2003. Saiu do programa para trabalhar como consultora, tendo trabalhado para diversas organizações internacionais na área de aids - Save the Children, Grã-Bretanha; Pact, EUA; PNUD, Angola; Interchurch Coordination Commitee, Holanda; Gesellschaft fur Technische Zusammenarbeit, Alemanha; Schorer, Holanda - e mais recentemente na área de câncer de mama - American Cancer Society, EUA. Não considera que possa retornar à militância depois de ter assumido uma função no Programa Nacional.

\section{Referências}

BARROS, S. G. de. A política nacional de luta contra a aids e o espaço aids no Brasil. 2013. 274 f. Tese (Doutorado em Saúde Pública) - Instituto de Saúde Coletiva, Universidade Federal da Bahia, Salvador, 2013.

CÂMARA, C. Uma trajetória individual e vários percursos. São Paulo: USP, Faculdade de Saúde Pública, 2009. Memorial.

SILVA, C. L. C. da. Currículo do sistema Currículo Lattes. [S.l.], 2011.

Disponível em: <http://lattes.cnpq.br/0335905033138788>. Acesso em: 3 maio 2011. 


\section{Eduardo Jorge Bastos Côrtes}

Natural de Caratinga, Minas Gerais, seu pai era comerciante e sua mãe dona de casa. Seu avô materno era médico. Cursou o ensino médio na sua cidade natal até o segundo ano científico, concluindo essa etapa na capital do estado, Belo Horizonte. Formou-se em Medicina pela UFRJ, onde também cursou Residência Médica em Terapia Intensiva. Eduardo Côrtes refere que se sentia atraído pela profissão, assim como outras. Diz que não consegue apontar um motivo específico para a escolha da medicina. Em 1977, ingressou como médico e docente da UFRJ. Em 1983, optou por fazer mestrado em oncologia na Universidade da Califórnia (UCLA), um dos principais centros de estudo sobre aids, na época, quando estudou as neoplasias da aids. Teve a oportunidade de conhecer, na UCLA, os pesquisadores americanos que primeiro descreveram a aids. Permaneceu ainda um período como Faculty Junior (professor júnior) na UCLA. Côrtes refere que voltou para o Brasil porque sentiu “que alguém precisava mostrar os dados do Brasil de que a epidemia era um problema muito sério e que o governo estava negando" ${ }^{131}$ Côrtes sempre participou de grêmio na época do colégio, foi residente chefe e representante de docentes na associação de docentes na universidade, mas nunca filiou-se a partido político. Considera-se democrático e refere que sua atuação política sempre esteve relacionada à questão científica. Realizou estudo que identificou a introdução do HIV-2 no Brasil. Durante a realização do estudo, teve apoio do jornalista Tim Lopes, que contribuiu para a divulgação da pesquisa, dando visibilidade ao seu trabalho. Em 1990, no governo Collor de Melo, foi convidado pelo Secretário Nacional de Assistência à Saúde, Ricardo Ackel para assumir a Divisão Nacional de Aids. Sua indicação não foi política, segundo Côrtes, ele foi convidado como um técnico respeitado na época, 
cargo que permaneceu até fevereiro de 1992. Côrtes não permaneceu no espaço aids. Após a saída da gestão do Programa Nacional, Côrtes tentou continuar na área, mas se sentia boicotado pelos agentes dominantes do espaço aids, de modo que como é oncologista de formação foi mudando aos poucos a sua linha de pesquisa. Em 2006 concluiu o doutorado em Cirurgia Geral na UFRJ, com a tese Impacto da superexpressão do oncogen HER-2/neu e de outros marcadores clínico-patológicos na sobrevida da mulher com carcinoma de mama, tendo como orientador o Professor Gutemberg Leão Almeida Filho. No final de 2013, foi empossado diretor do Hospital Universitário Clementino Fraga Filho (UFRJ).

\section{Referências}

BARROS, S. G. de. A política nacional de luta contra a aids e o espaço aids no Brasil. 2013. 274f. Tese (Doutorado em Saúde Pública) - Instituto de Saúde Coletiva, Universidade Federal da Bahia, Salvador, 2013.

CORTES, E. J. B. Currículo do sistema Currículo Lattes. [S.1.], 2009.

Disponível em: <http://lattes.cnpq.br/3723963692468488>. Acesso em: 18 maio 2011. 


\section{Eduardo Luiz Barbosa}

Nasceu em 1961, em Chavantes, São Paulo. Sua família materna veio do Líbano para o Brasil, onde conquistaram um bom padrão de vida, tornando-se uma família conhecida e tradicional na cidade. Seu pai, filho de trabalhador rural, teve uma loja, mas não era bom administrador na visão de Eduardo. Elegeu-se vereador e depois assumiu a função de assessor na prefeitura da sua cidade na gestão de diferentes prefeitos, sempre ligado à Arena (Aliança Renovadora Nacional). Sua mãe era dona de casa. Eduardo cursou o ensino médio em uma escola pública no município de Chavantes. Com intenção de se tornar religioso, foi para um seminário católico, ao mesmo tempo em que cursava filosofia na UNESP, em Marília, São Paulo. Cursou três anos do seminário, não chegando a concluir a formação em teologia. Teve atuação em grêmios estudantis e no movimento eclesial de base, o que considera que o motivou para a atuação na área social. Formado em Filosofia, foi para a capital do estado, São Paulo, onde, em 1986, tornou-se professor da rede estadual de ensino, onde, desde aquela época, realizava um trabalho educativo junto aos alunos abordando aspectos da epidemia, formas de prevenção da aids e questões de sexualidade. Apesar disso, não modificou as suas práticas sexuais, acreditando que as características pessoais de seus parceiros (homens e mulheres) não o colocavam em risco. Em 1994, teve diagnóstico positivo para o HIV, e passou a integrar o Grupo de Incentivo à Vida (GIV), no qual, junto com outros soropositivos, aprendeu que era possível ter qualidade de vida apesar da soropositividade e a lutar pela sua vida e a apoiar outras pessoas a superarem as barreiras que o HIV impõe. Foi presidente do GIV e atuou também na Rede Nacional de Pessoas Vivendo com HIV/aids (RNP+).Em 2001 foi eleito presidente do Fórum Estadual de ONGs/Aids de São Paulo. Como desdobramento dessa atuação, em agosto de 2004 foi convidado a trabalhar no Programa Nacional de DST e Aids do Ministério 
da Saúde, onde foi responsável adjunto da Unidade de Articulação com a Sociedade Civil e Direitos Humanos, passando à responsável pelo setor em 2006. Em maio de 2011, Eduardo Barbosa assumiu o cargo de diretor adjunto do Departamento de DST, Aids e Hepatites Virais.

\section{Referências}

BARROS, S. G. de. A política nacional de luta contra a aids e o espaço aids no Brasil. 2013.274 f. Tese (Doutorado em Saúde Pública) - Instituto de Saúde Coletiva, Universidade Federal da Bahia, Salvador, 2013.

NAÇÕES UNIDAS. Escritório contra Drogas e Crime. Eduardo Luiz Barbosa, 44. [S.1., 20--] Texto sobre Eduardo Luiz Barbosa. Disponível em: <http://www.unodc.org/pdf/1dec_05/Eduardo_pt.pdf >. Acesso em: 30 jul. 2011. 
Nasceu em 15 de abril de 1946, em São Paulo, SP. Filho de um escocês e uma brasileira, ele, corretor de seguros, ela, dona de casa. Edward foi criado na Inglaterra, onde cursou o ensino médio e graduou-se em Psicologia Social pela University of Sussex (1965-1968). Como não se identificou muito com a Psicologia, e tinha um interesse em conhecer melhor o Brasil, decidiu fazer o mestrado em Sociologia da América Latina, na University of Essex (1970-1971) e retornou para o Brasil, onde trabalhou como professor de inglês durante alguns anos. Em 1977 retornou para a universidade para fazer um outro mestrado, pois considerava que o mestrado no Brasil, naquela época, era muito mais que na Inglaterra, na sua opinião, quase um doutorado. Iniciou o mestrado em Antropologia na Unicamp, que na época não tinha doutorado, e conseguiu transferir-se para o doutorado da USP, onde concluiu o curso (1980-1986), sob a orientação de Eunice Durant. Sua pesquisa, publicada sob a forma de livro com o título A construção da igualdade: identidade sexual e política no Brasil da abertura, em 1990, versava sobre o primeiro grupo do movimento homossexual do país, o grupo Somos, que, para ele, foi uma "escola de militância”. ${ }^{132}$ Edward MacRae participou da reunião com o médico infectologista e professor da USP, Ricardo Veronesi, e compôs o grupo de militantes que foi à audiência com o Secretário de Saúde de São Paulo, João Yunes. Foi um dos fundadores do Gapa-SP, foi professor substituto da Unicamp (1982), professor titular da Fundação Escola de Sociologia e Política de São Paulo (1986). Com a conclusão da tese de doutorado, a briga do Somos e passada a fase inicial da epidemia da aids, Edward se afastou do grupo e mais tarde da discussão sobre homossexualidade. Mas seu espírito militante o aproximou de um outro tema que considerava ter um tratamento hipócrita: a questão do uso da maconha. Interessado nessa área, buscou o Instituto de Medicina Social e de Criminologia de

132 Declaração obtida em entrevista concedida à autora. 
São Paulo (Imesc), onde existia um grupo de estudos acerca do tema. Foi apresentado ao então superintendente do órgão por uma amiga e terminou conseguindo uma bolsa para realizar um estudo sobre drogas e ficou como diretor desse centro de estudos para prevenção do uso de drogas, entre 1988 e 1989, período em que iniciaram as discussões acerca da questão da aids entre usuários de drogas injetáveis no CRT-SP, e Edward foi indicado como representante do Imesc e participou da formulação da política voltada para esse grupo no estado de São Paulo. Em 1990, seu irmão faleceu vítima da aids. Edward ficou muito desgostoso com o tema da aids, pois, mesmo trabalhando na área, não foi capaz de evitar a contaminação do irmão. Resolveu então se afastar do espaço aids. Mudou-se para Salvador, onde geralmente passava férias, a partir de uma oportunidade de trabalhar no Centro de Estudo e Tratamento do Abuso de Drogas (Cetad). Desde 1995 é professor da Universidade Federal da Bahia e, desde 2003, é colaborador e membro da Câmara Nacional de Assessoramento técnico-científico do Conselho Nacional de Drogas (Conad). É membro do corpo editorial da revista Cadernos de Campo (USP), do qual também é revisor, desde 2006, e do Jornal Brasileiro de Dependências Químicas, desde 2001 e revisor dos periódicos revista Habitus (2007), revista Saúde e Sociedade (2008) e Internacional Journal of Drug Policy (2008-atual). Tem escrito livros sobre sexualidade, movimentos sociais, o uso socialmente integrado de substâncias psicoativas e redução de danos associados ao uso de drogas. Autor de 12 livros e 37 capítulos de livro. Orientador de mestrado e doutorado.

\section{Referências}

ABBADE, Á. C. da S.; BAIÃO, F. (Org.). 100 nomes que fizeram a história da luta contra a aids no Brasil. São Paulo: GAPA BR SP, 2010. p. 41.

BARROS, S. G. de. A política nacional de luta contra a aids e o espaço aids no Brasil. 2013. 274 f. Tese (Doutorado em Saúde Pública) - Instituto de Saúde Coletiva, Universidade Federal da Bahia, Salvador, 2013.

MACRAE, E. J. B. das N. Currículo do sistema Currículo Lattes. [S.1.], 2011. Disponível em: $<$ http://lattes.cnpq.br/3168537231736605>. Acesso em: 18 maio 2011. 
O baiano Euclides Castilho nasceu em Salvador, em 1941. Cursou o ensino médio no Colégio Central da Bahia, unidade da rede estadual de ensino de Salvador. Filho de um telegrafista e de uma dona de casa de origem portuguesa, oriundo de família de classe média-baixa, fez um teste vocacional e baseado no resultado, optou por cursar medicina, na UFBA (19601965). Em seguida fez Residência em Medicina Preventiva (USP Ribeirão Preto) entre 1966 e 1967 e depois foi bolsista da Milbank Fondation na Universidade Valle Cali, na Colômbia (1967-1968). Em 1968, a convite de Guilherme Rodrigues da Silva, seu orientador de doutorado, foi o primeiro docente contratado do Departamento de Medicina Preventiva (DMP) da USP. Doutor em Medicina Preventiva pela USP (1971), entre 1973 e 1975 fez pós-doutorado na Universidade da Califórnia do Norte e tornou-se livre-docente em 1976 (USP). Em 1985 pediu demissão da USP para aceitar o convite de Sérgio Arouca, seu contemporâneo na Medicina Preventiva da instituição - Arouca era interno quando Euclides Castilho fez a Residência -, para criar um centro de formação em saúde na Fiocruz, que hoje é o Instituto de Comunicação e Informação Científica e Tecnológica em Saúde (ICICT). Na Fiocruz iniciou o contato com a epidemia da aids. Foi convidado por Bernardo Galvão Castro Filho para compor a equipe do Laboratório de Imunologia que, naquele momento, buscava se credenciar como referencia para a OMS e precisava de um epidemiologista. É membro nato da Cnaids desde a sua primeira formulação. Em 1993, foi cedido pela Fiocruz ao MS para atuar no Programa Nacional de DST/ Aids. Entre 1996 e 2000, foi coordenador adjunto do Programa. Em 2000, ingressou outra vez na USP, através de concurso público. É professor titular do DMP da USP, pesquisador sênior do CNPq, membro do conselho editorial dos periódicos Revista da Sociedade Brasileira de Medicina Tropical, desde 1985, Revista do Instituto de Medicina Tropical de São Paulo, 
desde 2002, Clinics - São Paulo, desde 2003, Revista de Saúde Pública, desde 2008, Revista Brasileira de Epidemiologia, desde 2008, Ciência \& Saúde Coletiva, desde 2007. Recebeu diversos prêmios e homenagens, de instituições ligadas à área da saúde e à luta contra a aids como CDC (EUA), em 1989; APTA-São Paulo, em 2000; Ministério da Saúde, em 2009; Gapa-SP, em 2010; assim como de instituições, como da Federação de Indústrias de São Paulo (FIESP), em 2007, em reconhecimento às suas atividades relacionadas à epidemia da aids. Possui 107 artigos publicados, além de dois livros e 19 capítulos de livro. É orientador de mestrado e doutorado. Entre 2001 e 2002, participou como chair do Evaluation Supervisory Panel Fiveyear Evaluation of Unaids. Em 2006, 2008 e 2010 foi consultor do Fundo Global de Aids, Tuberculose e Malária.

\section{Referências}

ABBADE, Á. C. da S.; BAIÃO, F. (Org.). 100 nomes que fizeram a história da luta contra a aids no Brasil. São Paulo: GAPA BR SP, 2010. p. 47.

BARROS, S. G. de. A política nacional de luta contra a aids e o espaço aids no Brasil. 2013.274f. Tese (Doutorado em Saúde Pública) - Instituto de Saúde Coletiva, Universidade Federal da Bahia, Salvador, 2013.

CASTILHO, E. A. de. Currículo do sistema Currículo Lattes. [S.1.], 2011.

Disponível em: <http://lattes.cnpq.br/3112674950616014>. Acesso em: 18 abr. 2011. 
Fabíola de Aguiar Nunes

Nasceu em Salvador, Bahia, em 24 de outubro de 1943. Sua mãe era bacharel em Direito e trabalhava como consultora jurídica da Câmara. Bisneta, neta e filha de médico, nunca admitiu outra profissão. Mas nunca pensou em médico como clínico, pois o pai era sanitarista e o tinha como exemplo. Graduou-se em Medicina (1963-1968) pela UFBA. Durante toda a graduação trabalhou como oficial judiciário na justiça do trabalho. Em 1968, ainda estudante de medicina, durante o período de internato, foi para a Costa Rica fazer um curso de registros hospitalares, com bolsa da Opas, indicada por Jorge Novis, então diretor da escola de medicina. Quando retornou, formou-se, pediu demissão da justiça do trabalho e, no início de 1969, já estava como funcionária contratada do Hospital Universitário Professor Edgar Santos (Hupes) com a responsabilidade do arquivo médico. Foi responsável pela reestruturação do serviço de arquivo médico do Hupes até 1971. Entre 1971 e 1973, fez o mestrado em Saúde Pública, com concentração em administração de serviços de saúde, na Escola de Saúde Pública da Universidade da Califórnia, EUA. Retornou ao arquivo do Hupes e ministrava a disciplina de Serviços de Saúde e Epidemiologia para o curso de Farmácia. Chegou a assumir a vice-direção do Hupes (1974) e foi coordenadora do mestrado em Saúde Pública. Fez concursos para bolsa do DDA, para ir à Alemanha, solicitou bolsa ao Conselho Britânico e fez um concurso da Opas. Optou pela Opas. Entre 1980-1981, foi para o Programa de Saúde Pública na Costa Rica, o programa de Planejamento Estratégico Centro América Panamá (Pascap), trabalhar como oficial médico de saúde pública em um programa de atenção primária. Quando retornou para o Brasil, foi trabalhar no Ministério da Educação (MEC), no programa de infecção hospitalar, e ficou também como docente da UnB, ministrando aulas de Administração de Serviços de Saúde para os cursos de medicina, enfermagem e odontologia. Toda a trajetória de Fabíola Nunes se deu no 
serviço público, transitando entre a universidade e o serviço, mas sempre relacionada à gestão. Esposa do também médico e deputado Carlos Sant'Anna, que, em 1985, assumiu o Ministério da Saúde, Fabíola foi indicada pelo então secretário de saúde do estado de São Paulo, João Yunes, para a Secretaria Nacional de Programas Especiais de Saúde (SNPES), onde estavam os programas de controle de agravos como tuberculose e dermatologia sanitária (DST/Aids, hanseníase, leishmaniose tegumentar) e o programa de doenças crônico-degenerativas (diabetes, hipertensão e câncer). Foi durante a gestão de Fabíola na SNPES que foi criado o Programa Nacional de DST/Aids. Permaneceu na SNPES até 1987. Fabíola foi delegada do Ministério da Saúde na 8 a Conferência Nacional de Saúde. Na Assembleia Nacional Constituinte, acompanhou o processo de elaboração do capítulo referente à saúde por indicação do Núcleo de Estudos em Saúde Pública (Nesp) do Departamento de Saúde Coletiva da UnB. Trabalhou no Hospital da UnB, foi aprovada no concurso da Fundação Hospitalar do Distrito Federal, assumiu a coordenação da equipe distrital de controle de infecções e posteriormente a chefia do serviço de controle de infecções hospitalares do Hospital Regional de Sobradinho (DF). À convite do Ministro da Saúde, Adib Jatene, em 1995, assumiu a coordenação do Conselho Nacional de Saúde. Em 1997, retornou ao Hospital de Sobradinho. Entre 2001 e 2003, assumiu a coordenação da Fundação Oswaldo Cruz em Brasília. Retornou às atividades de médica sanitarista da Fundação Hospitalar do DF, aposentando-se em julho de 2005. Em 2008, foi representante do Ministro no Conselho Nacional de Saúde. Em 2009, retornou à Fiocruz Brasília e em 2010 foi Secretária de Saúde do Distrito Federal.

\section{Referências}

BARROS, S. G. de. A política nacional de luta contra a aids e o espaço aids no Brasil. 2013.274f. Tese (Doutorado em Saúde Pública) - Instituto de Saúde Coletiva, Universidade Federal da Bahia, Salvador, 2013.

Entrevista concedida à professora Ligia Maria Vieira da Silva, em 12 de novembro de 2008, para o Projeto Espaço da Saúde Coletiva. 
MACIEL, L. R.; OLIVEIRA, M. L. W. de; GALLO, M. E. N. Memória e história da hanseníase no Brasil através de seus depoentes (1960-2000). Rio de Janeiro: Casa de Oswaldo Cruz, Departamento de Arquivo e Documentação, 2010. p. 61-62. 
Nasceu em 6 de maio de 1960, em Teresina, Piauí. Filho de um servidor público e uma dona de casa, Gerson estudou em colégios públicos e em colégios jesuítas no Piauí. Seu primeiro vestibular foi para Odontologia, no ano seguinte fez novo vestibular para Medicina. Passou a frequentar os dois cursos, mas achava que não tinha condição técnica de fazer odontologia e optou pela Medicina, na UFPB (1977-1983). Fez Residência em Dermatologia, no Sanatório Aimorés, Bauru-SP (1984), Especialização em Saúde Pública, no Centro Universitário de Brasília (CEUB), Especialização em Epidemiologia pela Fiocruz-RJ (1988). Fez mestrado em Epidemiologia entre 1996 e 1999, na Escola Paulista de Medicina, Unifesp. Após a residência, foi convidado por Aguinaldo Gonçalves, seu professor na Residência, para trabalhar na Divisão Nacional de Dermatologia Sanitária (DNDS), onde permaneceu até 1990 e participou de projetos importantes no combate à hanseníase, como a introdução efetiva da poliquimioterapia para todo o Brasil a partir de 1985 e início do controle da aids. Trabalhou nos primeiros anos do Programa Nacional de DST/Aids. Participou da $8^{a}$ Conferência Nacional de Saúde. Era militante do PT, não era filiado ao partido, mas trabalhou no início. Quando o programa foi separado da DNDS, em 1987, optou pelo Programa de Hanseníase, devido à sua formação, só retornando em 2004 ao Programa de DST/Aids. Foi efetivado como servidor do Ministério da Saúde quando exercia o papel de médico da Campanha Nacional de Tuberculose, em 1988. Atuou no Programa Nacional de Controle da Hanseníase entre 1984 e 2003; chefiou a Coordenação Nacional de Dermatologia Sanitária no Centro Nacional de Epidemiologia (Cenepi), da Fundação Nacional de Saúde, em 1994 e 1995, e na Secretaria de Atenção à Saúde, entre 1999 e 2003. Desde 2004 trabalha na área técnica de Epidemiologia do Programa de DST/Aids do Ministério da Saúde. 


\section{Referências}

BARROS, S. G. de. A política nacional de luta contra a aids e o espaço aids no Brasil. 2013.274f. Tese (Doutorado em Saúde Pública) - Instituto de Saúde Coletiva, Universidade Federal da Bahia, Salvador, 2013.

MACIEL, L. R.; OLIVEIRA, M. L. W. de; GALLO, M. E. N. Memória e história da hanseníase no Brasil através de seus depoentes (1960-2000). Rio de Janeiro: Casa de Oswaldo Cruz, Departamento de Arquivo e Documentação, 2010. p. 70-71. 
Nasceu em 1959, em Porto Alegre, Rio Grande do Sul. Seu pai era vendedor, teve uma empresa e trabalhou com alugueis de imóveis e condomínios. Quando tinha 15 anos de idade, Gerson fazia transcrições dos textos em Braile para ONGs que prestavam assistência a portadores de deficiência visual. Na escola sempre participou de centro de estudantes e era voltado para a militância. Foi do "Partidão", 133 e depois migrou para o PT. Em 1983, iniciou a graduação em Serviço Social na Universidade do Vale dos Sinos (Unisinos), mas não chegou a concluir o curso. Em 1986, descobriuse portador do HIV. Era um momento em que ainda não existia tratamento e Gerson refere que "as pessoas morriam como moscas" 133 e que aquele foi um momento de grande rebeldia das pessoas infectadas. Após perder seu companheiro vitimado pela aids em 1988, Gerson procurou pessoas interessadas em fundar a primeira ONG/aids do Rio Grande do Sul. Junto com mais algumas pessoas, fundou o Gapa-RS, do qual foi presidente de 1989 a 1992. Tornou-se o primeiro soropositivo a assumir um programa de controle da aids: entre 1993 a 1998, foi Coordenador do Programa de DST/ Aids do Município de Porto Alegre, RS. Entre 1998 e 2000, trabalhou com direitos humanos na Assembléia Legislativa do Estado, sendo convidado pelo secretário da Justiça e Segurança, José Paulo Bisol, em 2000, para coordenar o Programa Estadual de Proteção a Testemunhas Ameaçadas (Protege). Quando saiu do cargo, por volta de 2003-2004, resolveu montar o seu próprio negócio e abriu uma padaria. Como sentia falta de alguma coisa para administrar o negócio, resolveu retornar para a faculdade. Em 2006 iniciou a graduação em Administração de Empresas, no Centro Universitário Metodista, RS, que concluiu em 2009. Em 2011, assumiu a Coordenação do Programa Estadual de DST/Aids do Rio Grande do 
Sul, cargo no qual permaneceu por 60 dias. Em seguida retornou para a Coordenação do Programa de Aids do Município de Porto Alegre.

\section{Referências}

ABBADE, Á. C. da S.; BAIÃO, F. (Org.). 100 nomes que fizeram a história da luta contra a aids no Brasil. São Paulo: GAPA BR SP, 2010. p. 55.

BARROS, S. G. de. A política nacional de luta contra a aids e o espaço aids no Brasil. 2013.274f. Tese (Doutorado em Saúde Pública) - Instituto de Saúde Coletiva, Universidade Federal da Bahia, Salvador, 2013.

WINKLER, G. B. Currículo do sistema Currículo Lattes. [S.1.], 2011.

Disponível em: <http://lattes.cnpq.br/0744896869738072>. Acesso em: 18 maio 2011. 


\section{Gilvane Casimiro}

Nasceu em 27 de outubro de 1965 no Ceará. Oriundo de uma família de agricultores, desde muito cedo se interessou pela área de educação. Gil dava aulas e chegou a trabalhar na rede de ensino municipal. Fez curso de qualificação de professor de primeiro grau, dentro de um plano educacional do governo. Antes de se mudar para São Paulo, já havia se envolvido com a Comissão Pastoral da Terra, fazendo parte do movimento eclesial de base. Em São Paulo, envolveu-se com um grupo de jovens ligados à igreja, onde permaneceu cerca de dois anos, mas terminou se afastando. Formou-se em hotelaria, na Faculdade Hebraico Brasileira Renascença de São Paulo. Quando terminou os estudos, através de um amigo, começou a se envolver, ainda timidamente, com o Grupo de Incentivo à Vida (GIV). Inicialmente trabalhava como garçom em festas e eventos promovidos pelo grupo, depois passou a se envolver em questões mais administrativas. Nesse ínterim, se descobriu soropositivo. Na época trabalhava no comércio na parte administrativa. Quando a direção da empresa em que trabalhava tomou conhecimento da sua soropositividade, foi afastado. Durante cerca de sete anos em que ficou afastado, dedicou-se exclusivamente ao ativismo no GIV. Quando começou ia dois três dias por semana quando saía do trabalho, aos poucos, passou a ir todos os dias. Foi suplente da tesouraria, foi tesoureiro, e chegou a presidente da instituição, permanecendo por três anos. Seu envolvimento maior com a instituição foi entre 1996 e 2004. Foi inclusive membro da Cnaids e das comissões em nível municipal e estadual, enquanto era representante do GIV. No início de 2005 , afastou-se do GIV. Considerava que não estava crescendo profissionalmente. Quando surgiu uma seleção para uma vaga na Secretaria de Saúde do Município de São Paulo passou então a trabalhar na articulação com a sociedade civil organizada. Assumiu como técnico e, em seis meses, passou à função de responsável pela área. Permaneceu cerca de cinco 
anos, de 2005 ao final de 2009, quando foi para o Ministério da Saúde, também no setor de articulação com a sociedade civil.

\section{Referências}

BARROS, S. G. de. A política nacional de luta contra a aids e o espaço aids no Brasil. 2013. 274 f. Tese (Doutorado em Saúde Pública) - Instituto de Saúde Coletiva, Universidade Federal da Bahia, Salvador, 2013. 
Harley Henriques do Nascimento

Nasceu em 1968, em Campina Grande, Paraíba. Com um ano de idade foi morar em Feira de Santana, Bahia. Filho de um comerciante e uma dona de casa que, com a morte do marido, passou a costurar para fora, chegando, mais tarde, a ter um comércio de roupas. Harley cursou o ensino médio em Feira de Santana. Achava que poderia fazer um curso que o permitisse trabalhar na área de gestão. Foi para a capital do estado, Salvador, cursar Administração de Empresas, na Universidade Católica. Participante do movimento eclesial de base, foi na segunda metade da década de $1980 \mathrm{em}$ que passou a participar mais ativamente do movimento estudantil, momento em que a aids estava bastante presente na mídia. Na sua opinião, a associação entre sexualidade e morte preocupou o grupo de amigos em início da vida sexual. Harley buscou informação sobre a doença na Bahia e não encontrou. De acordo com seu ponto de vista, não havia uma organização não governamental trabalhando com o tema. Havia ações promovidas pelo Grupo Gay da Bahia, mas tendo como alvo a comunidade gay, não existia uma associação que trabalhasse de forma exclusiva e ampla - para toda a sociedade - na área de aids. As ações governamentais ainda eram muito incipientes no estado da Bahia no ano de 1988. Harley tomou conhecimento de que naquele momento já existiam ONGs trabalhando na luta contra a epidemia de aids. Conheceu o Gapa-RJ e o Gapa-SP e resolveu fundar um Gapa em Salvador, junto com um grupo de amigos; todos universitários. Envolvido com o Gapa-BA, do qual se tornou coordenador geral em 1988, Harley adiou a conclusão do curso de Administração, mas considera que sua formação permitiu uma visão profissional de como trabalhar no terceiro setor. Entre 2003 e 2004, concluiu a graduação em Administração de Empresas na Universidade Católica e, em seguida, fez o mestrado (20052008) na mesma área, na UFBA. Harley foi assessor do Projeto Previna, do Programa Nacional de DST/Aids do Ministério da Saúde. 


\section{Referências}

ABBADE, Á. C. da S.; BAIÃO, F. (Org.). 100 nomes que fizeram a história da luta contra a aids no Brasil. São Paulo: GAPA BR SP, 2010. p. 61.

BARROS, S. G. de. A política nacional de luta contra a aids e o espaço aids no Brasil. 2013. 274 f. Tese (Doutorado em Saúde Pública) - Instituto de Saúde Coletiva, Universidade Federal da Bahia, Salvador, 2013. 
Nasceu na década de 1960, em Brasília. Seu pai era policial civil e sua mãe dona de casa. Fez faculdade de turismo. Pensava em trabalhar com a cultura dos países, conhecer o seu país. Estava cursando a faculdade e trabalhava em um banco quando foi aprovada em concurso para o Ministério da Saúde. Dois irmãos já trabalhavam no ministério, tendo sido contratados nas campanhas de tuberculose e febre amarela. Ingressou no ministério da Saúde em outubro de 1984. Ficou um tempo na Secretaria Executiva, trabalhava no apoio administrativo, quando foi para o Programa de Aids em 1986, o mesmo que já havia sido estruturado e precisava de uma secretária que falasse inglês. Ieda diz que vestiu a camisa da aids e permanece como Secretária do Departamento Nacional de DST, aids e hepatites virais até os dias atuais. Ieda só se afastou do Programa Nacional na gestão de Eduardo Côrtes, quando voltou para a Secretaria Executiva. Durante todo o período no Programa Nacional, acompanhou e auxiliou nas demandas de Cnaids. Em 2011, Ieda estava cursando Psicologia. Seu objetivo era concluir o curso e fazer trabalho comunitário.

\section{Referências}

BARROS, S. G. de. A política nacional de luta contra a aids e o espaço aids no Brasil. 2013.274 f. Tese (Doutorado em Saúde Pública) - Instituto de Saúde Coletiva, Universidade Federal da Bahia, Salvador, 2013.

SERVIDOR do mês. Ministério da Saúde Informa, Brasília, DF, ed. 5, mar. 2009. Disponível em: <http://dtr2001.saude.gov.br/ascom/edicao_5/ funcionario_do_mes.html>.Acesso em: 25 mar. 2012. 
Nasceu em 25 de novembro de 1954, em Fortaleza, Ceará. Cursou o ensino médio em São Paulo. Cursou Sociologia na Escola de Sociologia e Política de São Paulo. Relata que, desde o ensino médio, participava do movimento estudantil, tendo sido natural escolher uma área de atuação em que as questões sociais estavam sendo debatidas. Fez especialização no Instituto de Pesquisa Econômica Aplicada e na Faculdade Latino Americana de Ciências Sociais (Flacso). Iniciou o doutorado na UnB, mas não chegou a concluir, apesar de ter cursado todas as disciplinas, priorizando a atuação no campo burocrático em detrimento da vida acadêmica. A aproximação com a área da saúde se deu por intermédio de diversos agentes importantes da reforma sanitária brasileira, como Sérgio Arouca, Sebastião Loureiro, Jairnilson Paim, Naomar de Almeida Filho, pessoas que estavam pensando a saúde pública e a reforma sanitária e estavam constituindo a Abrasco e o Centro Brasileiro de Estudos de Saúde (Cebes). Compôs a diretoria do Cebes entre 1994 e 1995 ( $1^{\circ}$ suplente da tesouraria). O primeiro contato com a aids ocorreu alguns anos antes de se tornar técnico da área de prevenção do Programa Nacional de DST/Aids do Ministério da Saúde, quando foi convidado por Eleutério Rodrigues Neto para participar, junto com Alina Maria A. de Souza, de um artigo sob a perspectiva da saúde internacional, tendo como recorte a aids e a questão da cooperação internacional para um livro da Opas. Antes de ir para a UnB, foi docente da Universidade Federal da Paraíba por cerca de 17 anos, ministrava aulas na disciplina Saúde e Sociedade e integrava um grupo de pesquisa que trabalhava com a questão da saúde pública. Na UnB passou a integrar o Núcleo de Estudos de Saúde Pública (Nesp), lidando principalmente com as questões de análise de políticas públicas. Quando Jamil Haddad assumiu o ministério em outubro de 1992, Ivo Brito trabalhou no desmonte do Inamps. Em 1996, entrou no Programa Nacional de 
DST/Aids como técnico da área de prevenção, onde permanece até hoje. Entre 2002 e 2004, trabalhou na África, junto aos governos de Angola e Moçambique nas ações programáticas para a aids. Foi filiado ao PT, atualmente é filiado ao Partido da Causa Operária (PCO).

\section{Referências}

BARROS, S. G. de. A política nacional de luta contra a aids e o espaço aids no Brasil. 2013.274 f. Tese (Doutorado em Saúde Pública) - Instituto de Saúde Coletiva, Universidade Federal da Bahia, Salvador, 2013. 
Jorge Adrian Beloqui

Nasceu em 1949, em Buenos Aires, Argentina. Filho de um contador e uma enfermeira. Graduou-se (1968-1972) e depois fez mestrado em Matemática na Universidade de Buenos Aires. Lutou contra a ditadura argentina no movimento estudantil em 1969. Participou da corrente socialista do movimento peronista. Foi nomeado professor assistente logo que concluiu o mestrado, mas em 1974 - um ano e meio antes da ditadura -, foi demitido por razões políticas da universidade. Solicitou uma bolsa para fazer o doutorado (1976-1981) no Brasil, no Instituto Nacional de Matemática Pura e Aplicada (Impa). Ingressou no grupo Somos de Afirmação Sexual do Rio de Janeiro. Com o fim do doutorado, mudou-se para São Paulo e passou a frequentar o grupo Somos - SP, até 1983. Em 1981 ingressou como docente do Instituo de Matemática e Estatística da USP (IME). Sua relação com a aids começou em 1986, quando um amigo próximo morreu de aids. Um pouco depois, foi testado, contra a sua vontade, e descobriu-se soropositivo. Jorge Beloqui havia decidido não se testar porque não via sentido em saber o diagnóstico se não havia tratamento. Em 1986, participou da campanha de Herbert Daniel a deputado. Em 1989, conheceu o Pela Vidda, primeiro grupo de pessoas vivendo com HIV/aids, fundado por Herbert Daniel no Rio de Janeiro. Gostou do tom militante do grupo e participou da fundação do Pela Vidda São Paulo, em agosto de 1989. Participou do grupo Pela Vidda até 1995. Em janeiro de 1996, entrou para o Grupo de Incentivo à Vida (GIV). É pesquisador colaborador do Núcleo de Estudos e Prevenção à Aids (Nepaids) da USP. Membro de corpo editorial da HIV Vaccines Bulletin, membro do The Advisory Board da Associação Brasileira Interdisciplinar de Aids (Abia), diretor do Grupo de Incentivo à Vida (GIV), membro da Working Group on Intellectual Property, Working Group on Prevention for PWHIV/AIDS da National STD-AIDS Program, membro de corpo editorial da Cadernos 
pela Vidda, membro de corpo editorial da Boletim pela Vidda, revisor de periódicos da revista Panamericana de Salud Pública/Pan American Journal of Public Health e revisor de periódico da revista Brasileira de Epidemiologia.

\section{Referências}

ABBADE, Á. C. da S.; BAIÃO, F. (Org.). 100 nomes que fizeram a história da luta contra a aids no Brasil. São Paulo: GAPA BR SP, 2010. p. 85.

BARROS, S. G. de. A política nacional de luta contra a aids e o espaço aids no Brasil. 2013. 274f. Tese (Doutorado em Saúde Pública) - Instituto de Saúde Coletiva, Universidade Federal da Bahia, Salvador, 2013.

BELOQUI, J. A. Currículo do sistema Currículo Lattes. [S.1.], 2011.

Disponível em: <http://lattes.cnpq.br/2597867777721638>. Acesso em: 18 maio 2011.

BELOQUI, J. Ter HIV na USP: ou o uso do hífen na língua portuguesa. Revista Adusp, São Paulo, n. 6, p. 19-22, maio 1996. 
Nasceu em 1935, numa família portuguesa que veio para o Brasil no período da guerra. Em São Paulo, seu pai tinha um bar onde trabalhou na adolescência. Estudou no colégio Anglo Latino, um colégio particular. Cursou medicina na USP (1956-1961). Fez especialização em Epidemiologia na mesma instituição (1965-1967), tendo como orientador José Lima Pedreira de Freitas. Entre 1965-1970 fez o doutorado em Medicina, sob a orientação de Astolpho Ferraz de Siqueira, defendendo a tese intitulada Tábuas de vida e capacidade inata de aumento numérico de uma população de Triatoma infestans em condições de laboratório. Em 1963, ingressou como docente da Faculdade de Medicina da USP de Ribeirão Preto. Tornou-se livre docente pela USP (1975). Foi coordenador do campus da USP de Ribeirão Preto, nos anos de 1980, professor colaborador do Instituo de Estudos Avançados (IEA) da USP (1990 a 1992) e professor do Programa de Integração da América Latina (Prolam) da USP - 1995 a 2003. Na Secretaria de Estado da Saúde de São Paulo (SES/SP) foi diretor do Instituto de Saúde entre 1983 e 1985; e entre 1993 e 1999; e coordenador dos Institutos de Pesquisa nos períodos de 1983 a 1985 e 1999 a 2003. Era diretor do Instituto de Saúde e dos institutos de pesquisa quando da emergência da epidemia da aids no estado de São Paulo, quando foi criado o Programa Estadual de Aids. No Ministério de Saúde foi Assessor do ministro Almeida Machado (1975 a 1976) e consultor e membro de diversos comitês. Na Fundação Oswaldo Cruz (Fiocruz) foi diretor do Instituto Nacional de Controle de Qualidade em Saúde (INCQS), na década de 1980, coordenou o Projeto Inovação em Saúde (2003 a 2009) e recentemente foi vice-presidente de Pesquisa e Desenvolvimento Tecnológico (2007 a 2009); atualmente participa do Centro de Desenvolvimento Tecnológico em Saúde (CDTS) e é assessor do presidente da Fiocruz. Assessor da OMS e membro de Comitês Técnicos desde 1999, em especial 
do Comitê de Vacinas de HIV/aids (2000 a 2001) e do Comitê de Registro de Ensaios Clínicos (2006 a 2008). Membro da Associação Brasileira de Pós Graduação em Saúde Coletiva (Abrasco), foi o presidente (2006 a 2009) e, até março de 2007 , editor científico da Revista Brasileira de Epidemiologia. E também foi membro do Cebes.

\section{Referências}

BARROS, S. G. de. A política nacional de luta contra a aids e o espaço aids no Brasil.2013.274f. Tese (Doutorado em Saúde Pública) - Instituto de Saúde Coletiva, Universidade Federal da Bahia, Salvador, 2013.

CARVALHEIRO, J. da R. Currículo do sistema Currículo Lattes. [S.1.], 2011. Disponível em: <http://lattes.cnpq.br/1818832385881541>. Acesso em: 11 maio 2011. 


\section{Luiz Roberto de Barros Mott}

Nasceu em 6 de maio de 1946, em São Paulo capital. Filho de um comerciante atacadista do ramo da papelaria, que depois se tornou fazendeiro e de uma escritora de livros infantis. Cursou o ensino médio em um seminário na Escola Apostólica de São Domingos. Durante sua infância e adolescência queria ser padre da igreja católica. Foi seminarista em Juiz de Fora, Minas Gerais, da Ordem dos Dominicanos que tinha um posicionamento mais de esquerda, criticando a ditadura, inclusive participando do ocultamento do guerrilheiro Carlos Marighela. Aos 17 anos desistiu do sacerdócio e tornou-se "um ateu militante, marxista e sempre preocupado com as causas populares, humanistas" ${ }^{134}$ Graduou-se em Ciências Sociais na USP (1965-1968). Fez mestrado em Antropologia na Universidade Paris V (Sorbonne), entre 1969-1971, com o título: La structure de prodution de Brejo Grande, Sergipe, Brésil, sob a orientação de Jean Guiart. Entre 1972-1975, fez o doutorado em Antropologia Econômica na Unicamp, defendendo a tese A feira do Brejo Grande, Sergipe, tendo como orientadora Verena Martine Zalier. Foi docente da Unicamp (1972-1978). Em 1979, divorciou-se e assumiu publicamente a sua homossexualidade. Como Campinas lhe parecia uma cidade muito provinciana, resolveu vir morar na Bahia, que para Mott representava o “oásis da liberdade”. ${ }^{134}$ Veio como professor visitante do Departamento de Antropologia da UFBA, pensando em largar a universidade, mas com a possibilidade de se estabelecer no quadro permanente, estabeleceu-se como professor. Numa tarde, estava assistindo o pôr do sol no Farol da Barra com seu companheiro quando sofreu um ato de violência homofóbica. Resolveu escrever uma carta para o jornal Lampião da esquina convocando os gays da Bahia a escreverem para ele para formarem um grupo gay. Junto com cerca de 17 gays, entre 
advogados, jornalistas, professores, estudantes, fundou o Grupo Gay da Bahia (GGB) em fevereiro de 1980. O GGB tornou-se um dos pioneiros de importantes conquistas para a cidadania homossexual e na luta contra a aids, fundando grupos, produzindo e publicando inúmeros folhetos, cartazes, fazendo campanhas, participando da Comissão Nacional de Aids e fundando o grupo Vida Feliz de portadores de HIV/aids e o Centro Baiano Anti-Aids (CBAA). Mott destaca que o trabalho de prevenção à aids do GGB nunca se limitou à população homossexual, tendo importante trabalho na prevenção junto a terreiros de candomblé de Salvador, bem como publicou a primeira cartilha em braile para prevenção de deficientes visuais. Em 1999, fez concurso para professor titular da UFBA. Bolsista de produtividade $1 \mathrm{~A}$ do $\mathrm{CNPq}$, tem como linha de pesquisa a Etno-história da sexualidade no Brasil colonial e na atualidade, 64 artigos, 29 livros e 35 capítulos de livros publicados, diversos deles sobre homossexualidade e aids. Orientador de mestrado e doutorado.

\section{Referências}

ABBADE, Á. C. da S.; BAIÃO, F. (Org.). 100 nomes que fizeram a história da luta contra a aids no Brasil. São Paulo: GAPA BR SP, 2010. p. 105.

BARROS, S. G. de. A política nacional de luta contra a aids e o espaço aids no Brasil. 2013. 274f. Tese (Doutorado em Saúde Pública) - Instituto de Saúde Coletiva, Universidade Federal da Bahia, Salvador, 2013.

MOTT, L. R. de B. Currículo do sistema Currículo Lattes. [S.1.], 2010.

Disponível em: <http://lattes.cnpq.br/3331234730616226>. Acesso em: 15 mar. 2011. 
Filho de uma família baiana, Manoel nasceu e se criou em Brasília. Quando tinha 16 anos, era estagiário do gabinete da Secretaria Nacional de Programas Especiais de Saúde e foi para o Programa Nacional de DST/ Aids a convite de Lair Guerra. Seu pai trabalhava com madeiras e sua mãe era dona de casa. Manoel estudou em escola pública em Brasília e nunca se envolveu no movimento estudantil porque "não tinha tempo, trabalhava". ${ }^{135}$ Chegou ao programa quando este já tinha saído da DNDS, por volta de 1987. Em 1988, tornou-se quadro efetivo do Ministério da Saúde, através da realização de concurso público. Sempre trabalhou no Programa de DST/Aids. Afastou-se apenas por um período de cinco meses por volta de 2005 para ser assessor do ministro, mas terminou voltando. Não saiu nem no período em que Eduardo Côrtes foi coordenador, como a maioria dos técnicos. Era responsável pela reprografia e pela entrega de documentos. Manoel graduou-se em contabilidade pela UnB, fez especialização em planejamento e gestão e trabalha atualmente no setor de planejamento, é o ordenador de despesas do Departamento. Em 2011 pretendia fazer mestrado em avaliação na Fiocruz.

\section{Referências}

BARROS, S. G. de. A política nacional de luta contra a aids e o espaço aids no Brasil. 2013.274 f. Tese (Doutorado em Saúde Pública) - Instituto de Saúde Coletiva, Universidade Federal da Bahia, Salvador, 2013. 
Nasceu em 1968 em Salvador, Bahia. Filha de um representante de laboratório farmacêutico, sua mãe era dona de casa. Quando tinha oito anos, seu pai foi transferido para o município de Feira de Santana, onde cursou o ensino médio no colégio Padre Ovídio, da rede particular. Quando criança, sempre quis ser advogada. Fez vestibular com 16 anos, foi aprovada para o curso de Direito na UFBA. Desistiu do curso no final do primeiro ano e fez novo vestibular para Psicologia e migrou para aquele curso em 1985. Formou-se em 1991. Conheceu Harley Henriques do Nascimento em Feira de Santana, quando tinha 11 anos e ficaram amigos. Fez estágio no Detran, na área de recursos humanos, durante a faculdade, o que permitia a sua manutenção em Salvador. Fez estágio em vários locais nessa área. Fundou o Gapa-BA junto com Harley e outros amigos. Achava que era necessário fazer alguma coisa frente àquela epidemia. Nunca se envolveu em movimento estudantil ou com partidos políticos, apenas com o Gapa. Gosta do PT, e sempre votou no PT, mas nunca quis fazer parte do quadro. Fez mestrado (2004-2006) e iniciou o doutorado (2008) em Saúde Pública no ISC-UFBA. O tema da dissertação de mestrado foi Representações da sexualidade do adolescente por profissionais de saúde em unidades básicas e resultou de um trabalho desenvolvido por Márcia com adolescentes no Gapa, o objetivo era entender quais eram as representações sobre sexualidade de profissionais de saúde em uma unidade de atenção básica. O tema do doutorado foi o corpo e cirurgias plásticas femininas, que tinha vinculações com a sexualidade. Refere que a aids já é muito absorvente e que trabalhar outros temas foi uma forma de dialogar com outras áreas. Sua trajetória profissional se dá ao interior do espaço militante, no Gapa. 


\section{Referências}

BARROS, S. G. de. A política nacional de luta contra a aids e o espaço aids no Brasil. 2013.274f. Tese (Doutorado em Saúde Pública) - Instituto de Saúde Coletiva, Universidade Federal da Bahia, Salvador, 2013.

MARINHO, M. C. G. Currículo do sistema Currículo Lattes. [S.1.], 2011.

Disponível em: <http://lattes.cnpq.br/6935010706384693>. Acesso em: 18 maio 2011. 
Márcia Lilian Sampaio e Sampaio Sá

Natural de Valença, Bahia, filha de um eletrotécnico e uma professora de português, Márcia Sampaio estudou no Colégio Maristas, em Salvador. Desde os seis anos de idade dizia que queria ser médica e nunca desistiu. Cursou Medicina na UFBA (1984-1989). Sempre quis trabalhar com doenças crônico-degenerativas. Queria ser cardiologista. Foi aluna de Naomar Almeida Filho na disciplina de Epidemiologia e começou a trabalhar numa pesquisa com ele, mas Márcia não tinha coragem de fazer Saúde Pública ou Medicina Preventiva porque ela achava que deixaria de ser médica. Assim, a área de doenças infecciosas surgiu como estratégia para juntar as duas áreas que gostava de atuar: a clínica e a epidemiologia. Fez Residência em Infectologia no Hospital Espanhol (1990-1992), onde trabalhou com o grupo chefiado pelo infectologista Roberto Badaró, que conduzia estudos de aids na Bahia em parceria com a Unversidade de Cornel. Quando concluiu a Residência, em 1992, fez concurso para a Secretaria de Saúde do Estado da Bahia e foi trabalhar na enfermaria de aids no Hospital Roberto Santos, onde permaneceu até 1997, quando foi para o Programa Estadual de DST/Aids atuar como técnica responsável pela vigilância epidemiológica das DST/Aids. Em 1995, fez um treinamento em São Francisco, EUA, na Universidade da Califórnia em prevenção de HIV/aids. No período de 1999 a 2004, foi coordenadora do Programa Estadual de DST/Aids. Foi exonerada do cargo e desligada do Programa de DST/Aids, sendo transferida para a coordenação de Vigilância Epidemiológica Hospitalar. Fez mestrado em Medicina e Saúde (2001-2003) na UFBA, defendendo a dissertação "Programa de prevenção da Infecção pelo HIV sobre o comportamento sexual de homossexuais masculinos em Salvador, Bahia”, orientada por Carlos Brites e entre 2003 e 2007, fez o doutorado no mesmo programa, defendendo a tese 100\% adesão: oficinas educativas versus sessões de vídeo para promover a adesão à terapia antirretroviral em pacientes com aids sem tratamento prévio em Salvador, Bahia. 


\section{Referências}

BARROS, S. G. de. A política nacional de luta contra a aids e o espaço aids no Brasil. 2013.274f. Tese (Doutorado em Saúde Pública) - Instituto de Saúde Coletiva, Universidade Federal da Bahia, Salvador, 2013.

SÁ, M. L. S. e S. Currículo do sistema Currículo Lattes. [S.1.], 2011. Disponível em: <http://lattes.cnpq.br/8472808968977223>. Acesso em: 24 maio 2011. 
Maria Inês Dourado é natural de Salvador, Bahia. Concluiu o ensino médio em 1975, no Colégio Maristas, tradicional colégio da rede privada de Salvador. Filha de um médico obstetra, professor universitário na área de ginecologia e uma enfermeira. No seu colégio, só era considerado inteligente quem cursava Medicina, Direito e Administração. Mas não houve pressão em casa para a escolha da profissão. Cursou medicina da Escola Baiana de Medicina e Saúde Pública entre 1976 e 1981. Em setembro de 1981 foi selecionada para a residência de Medicina Social, mas abandonou o curso com apenas dois meses para acompanhar o marido que tinha recebido uma bolsa para estudar nos EUA. Fez o mestrado em Saúde Pública na Universidade de Massachussetts, Amherst, EUA (1982-1984). No retorno para o Brasil, ingressou como médica na Secretaria de Saúde do estado da Bahia, permanecendo como técnica do Centro de Informação em Saúde, onde permaneceu de 1984 a 1989, e como médica pesquisadora na UFBA, passando a docente do Instituto de Saúde Coletiva, em 1997. Sua aproximação com a aids se deu a partir do doutorado realizado na Universidade da Califórnia entre 1989-1994, sob orientação de Roger Detels, que coordenava naquele momento um grande projeto de coorte em aids, chamado Multicenter Aids Cohort Study, que começou em 1984. A ideia era trabalhar num projeto sobre urbanização e esquistossomose, mas como não havia orientador, foi com os dados desse estudo de coorte que Inês fez a tese de doutorado. Atua nas seguintes linhas de pesquisa: epidemiologia do HIV, avaliação do impacto de intervenções, doenças imunopreveníveis, epidemiologia de retrovírus, epidemiologia de doenças infecciosas, HIV/aids, avaliação de tecnologia em saúde. Possui 64 artigos publicados e quatro capítulos de livro, vários relacionados à HIV/ aids. É pesquisadora 1C do CNPq, orientadora de mestrado e doutorado. 


\section{Referências}

BARROS, S. G. de. A política nacional de luta contra a aids e o espaço aids no Brasil. 2013.274f. Tese (Doutorado em Saúde Pública) - Instituto de Saúde Coletiva, Universidade Federal da Bahia, Salvador, 2013.

DOURADO, M. I. C. Currículo do sistema Currículo Lattes. [S.1.], 2011.

Disponível em: <http://lattes.cnpq.br/7845852622901449>. Acesso em: 18 maio 2011. 
Nasceu em 21 de abril de 1950, em Mucurici, Espírito Santo. Até os sete anos foi criada e alfabetizada na fazenda de sua família. Em 1968 foi para Vitória, finalizar os últimos anos do ensino médio nos colégios São Vicente de Paulo e o Salesiano. Em 1970 ingressou na Escola de Medicina da Santa Casa de Misericórdia de Vitória (Emescam) e, desde a graduação, manifestou interesse pela dermatologia. Em 1975, após uma tragédia pessoal, foi para o Rio de Janeiro terminar o último ano de graduação na UERJ, período em que foi bolsista de iniciação científica do CNPq no Instituto de Leprologia (IL). Nesse momento, a DNDS localizava-se no mesmo espaço do Instituto. Presenciou a transferência do IL para a Fiocruz, e da DNDS para Brasília. Após a especialização em Dermatologia (1976-1977) na UERJ, foi aprovada no concurso do Inamps como Médica Dermatologista, no município de Duque de Caxias, estado do Rio de Janeiro, onde iniciou seu trabalho com a Saúde Pública em hanseníase. Naquele período, participou do Grupo Popular de Saúde e fundou o primeiro Núcleo do Movimento de Reintegração das Pessoas atingidas pela Hanseníase (Morhan) do Rio de Janeiro. Em 1979 entrou para a UFRJ como auxiliar de ensino. Em 1984, a convite de Zulmira Hartz, foi trabalhar na Gerência Estadual de Dermatologia Sanitária da Secretaria de Saúde do estado do Rio de Janeiro, com os programas de hanseníase e aids. Em 1986, a convite de Fabíola de Aguiar Nunes, Secretária Nacional de Programas Especiais de Saúde, foi para a Divisão Nacional de Dermatologia Sanitária, onde acompanhou o Programa de Aids. Com o governo de Fernando Collor de Melo retornou à UFRJ. Fez mestrado em dermatologia na UFF (1990-1991) e doutorado também em dermatologia na UFRJ (1992-1996). Retornou à Coordenação Nacional de Dermatologia Sanitária entre 1996 e 1998. Coordenou o Departamento de Hanseníase da Sociedade Brasileira de Dermatologia (SBD) entre 2005-2006, quando 
iniciou a estratégia de campanhas municipais de hanseníase em vários estados. Foi novamente para o Ministério da Saúde em 2007-2008.

\section{Referências}

BARROS, S. G. de. A política nacional de luta contra a aids e o espaço aids no Brasil.2013.274f. Tese (Doutorado em Saúde Pública) - Instituto de Saúde Coletiva, Universidade Federal da Bahia, Salvador, 2013.

MACIEL, L. R.; OLIVEIRA, M. L. W. de; GALLO, M. E. N. Memória e história da hanseníase no Brasil através de seus depoentes (1960-2000). Rio de Janeiro: Casa de Oswaldo Cruz, Departamento de Arquivo e Documentação, 2010. p. 101-102.

OLIVEIRA, M. L. W. R. Currículo do sistema Currículo Lattes. [S.l.], 2012. Disponível em: <http://lattes.cnpq.br/8581392578360492>. Acesso em: 4 dez. 2012.

OLIVEIRA, M. L. W. R. Participação em quatro décadas da política de controle da hanseníase no Brasil: acasos e determinação. Hansenologia Internationalis, São Paulo, v.33, n. 2, p. 45-50, 2008. Suplemento 1. 
Nasceu em Santa Maria, São Paulo. Filho de um comerciante e uma professora, cursou o ensino médio no colégio Luiz Queiroz, um colégio particular da cidade de Piracicaba, São Paulo. Queria fazer jornalismo. Entrou na Universidade Estadual de Londrina (UEL) e chegou a cursar um semestre. Como desejava fazer política através da profissão, resolveu cursar Ciências Sociais na UNESP (1984-1987), em Araraquara. Fez mestrado em Ciências Sociais - Antropologia pela Pontifícia Universidade Católica de São Paulo (PUC-SP), entre 1988 e 1993, com a dissertação A Epidemia Clandestina: AIDS e Usuários de Drogas Injetáveis em São Paulo, um dos primeiros estudos sobre AIDS entre usuários de drogas injetáveis. Foi professor de várias faculdades e universidades, como: Instituto de Ciências Aplicadas (ISCA) (1988-1989), Faculdades Teresa MartinSP (1990-1992), Universidade Estadual de Londrina (UEL) (19921994), Fundação Armando Alvares Penteado (FAAP-SP) (1996-2000), Universidade Castelo Branco-SP (1996-1997), Universidade Estadual de Campinas (Unicamp) (1998-2000), Fundação Escola de Sociologia e Política de São Paulo (FESP-SP) (2001-2002), Universidade de Salvador (UNIFACS) (2002) e desde 2002 é docente da Universidade do Estado da Bahia (UNEB). Fez doutorado em Ciências Sociais - Antropologia (20022007), na Universidade Federal da Bahia (UFBA), com a tese denominada Coca light? Usos do corpo, rituais de consumo e carreiras de usuários de cocaína em São Paulo. Fez estágio de pós-doutorado (2009-2010) na Universidade de Columbia, Nova Iorque, EUA.

\section{Referências}

BARROS, S. G. de. A política nacional de luta contra a aids e o espaço aids no Brasil. 2013. 274f. Tese (Doutorado em Saúde Pública) - Instituto de Saúde Coletiva, Universidade Federal da Bahia, Salvador, 2013. 
FERNANDEZ, O. F. R. L. Currículo do sistema Currículo Lattes. [S.1.], 2011.

Disponível em: <http://lattes.cnpq.br/3890948700156466>. Acesso em: 18 maio 2011. 
Nasceu em Álvares Machado, São Paulo. Filho de um contador (nível médio) e de uma dona de casa. Seu avô paterno era fazendeiro, mas faliu antes do casamento de seus pais. O materno era empregado rural. A família era de formação católica, embora seus pais não frequentassem a igreja, ele frequentava por conta de atividades escolares e da comunidade. Cursou o ensino médio na cidade de Dourados e o último ano na capital, São Paulo. Fez Medicina na UNESP-Botucatu entre 1968-1973, uma escola relativamente nova, organizada com uma participação grande de docentes egressos da USP, que participavam do movimento de reforma universitária. O curso foi criado tendo como referência os princípios de organização da Universidade de Brasília, com uma ênfase grande em Medicina Preventiva. A escolha da medicina estava relacionada à imagem de médico herói dos romances, o médico que vai para lugares distantes salvar vidas. Fez Residência em Dermatologia (1974-1977) em convênio entre a Escola Paulista de Medicina e a Fundação Centro Nacional do Trabalho (Fundacentro). Participou do movimento estudantil durante a adolescência e a faculdade, foi preso por duas vezes por questões políticas: em 1968, quando era secretário geral do diretório acadêmico, ficou 30 dias no Dops; e no período de desarticulação da AP, da qual participou até 1974, foi sequestrado e ficou oito dias no DOI-CODI. Participou do movimento geral em torno do MDB e da anistia, em 1976, e se envolveu também no apoio ao movimento sindicalista do ABC. Fez parte do grupo que criou o PT, já na área da saúde, influenciado pelo movimento sanitário. Participou do grupo Somos de afirmação homossexual até 1979. O serviço de dermatoses profissionais em que ficava um dos turnos da Residência era financiado e dirigido pela Fundacentro, que era dirigida por militares. Com a prisão em 1974, foi desligado desse serviço, passando a se concentrar, a partir daquele momento, na dermatologia geral. Em 1978 foi aprovado 
em concurso público para a SES-SP, sendo designado para a Divisão de Hansenologia e Dermatologia Sanitária (DHDS), da qual se tornou diretor. Em 1983, coordenou a criação do Programa Estadual de Aids de São Paulo, sendo seu coordenador nos períodos de 1983-1987, 1990-1991, 1995-1996. Foi consultor da Opas (1994), Consultor técnico do Programa de Aids na ONU - Unaids, para América Central e Cone Sul (1996-1999). Entre 2000 e 2003 assumiu a coordenação do Programa Nacional de DST/ Aids. Na sua gestão foi proposta a "quebra de patentes" e o programa foi agraciado com o Prêmio Bill e Melinda Gates, considerado a ação de saúde pública mais relevante de 2002. Quando saiu do Programa Nacional foi diretor do Programa de Aids da OMS (2003-2004). Se define como um profissional de saúde pública, com área de concentração em aids e diz que fica tão aflito hoje quanto a vinte anos atrás, mas se sente satisfeito com o trabalho que fez e com a perspectiva de continuar.

\section{Referências:}

ABBADE, Á. C. da S.; BAIÃO, F. (Org.). 100 nomes que fizeram a história da luta contra a aids no Brasil. São Paulo: GAPA BR SP, 2010. p. 143.

BARROS, S. G. de. A política nacional de luta contra a aids e o espaço aids no Brasil. 2013. 274 f. Tese (Doutorado em Saúde Pública) - Instituto de Saúde Coletiva, Universidade Federal da Bahia, Salvador, 2013.

FRANÇA, M. S. J. Ciência em tempos de aids: uma análise da resposta pioneira de São Paulo à epidemia. 2008. 195 f. Tese (Doutorado em História da Ciência) - Pontifícia Universidade Católica de São Paulo, São Paulo, 2008. p. 115-125. 
Nasceu em 1951 em Mucugê, Bahia. Filho de um comerciante e uma dona de casa, seus avós paternos vieram da Síria e os maternos tinham origem libanesa. Pedro cursou o ensino médio no Rio de Janeiro e ingressou na faculdade de Medicina da UFRJ em 1972. Diz que decidiu fazer Medicina por sugestão da irmã. Durante a faculdade se filiou ao MDB e participava do Partido Comunista. Fazia parte da ala pró-moscou. Participava de treinamentos, reuniões, simulações. Em 1978 ingressou como médico da Fundação Serviços Especiais de Saúde Pública (FSESP), que considera uma grande escola de Saúde Pública. Chefiava o programa de doenças transmissíveis da FSESP, em 1986, no Rio de Janeiro. O ministério havia delegado ao SESP a função de normalizar notificação, consolidação de dados relativas às doenças transmissíveis no nível nacional, de modo que havia uma boa interação com a SNABS e a SNPES no Ministério da Saúde. A FSESP colaborou para a interiorização do Programa Nacional de DST/ Aids, através do treinamento de suas unidades. Fez especialização em Saúde Pública (USP) e Dermatologia Sanitária (ENSP). Em 1987, Pedro Chequer passou a integrar o PN DST/Aids, permanecendo até 1990, no governo Collor, quando retornou para a FSESP em Brasília. Entre 1991 e 1993, assumiu a Direção do Cenepi. Em 1993, retornou para o Programa Nacional de DST/Aids, assumindo a chefia do serviço de epidemiologia, e posteriormente, tornou-se coordenador substituto. Com o acidente sofrido por Lair Guerra, assumiu a direção do PN, entre 1996 e 2000, quando se tornou representante do Unaids no Cone Sul, entre 2002 e 2004 foi representante do Unaids na Rússia. No período de 2004 a 2006 foi mais uma vez diretor do PN. Desde 2006 é representante do Unaids no Brasil. 


\section{Referências}

ABBADE, Á. C. da S.; BAIÃO, F. (Org.). 100 nomes que fizeram a história da luta contra a aids no Brasil. São Paulo: GAPA BR SP, 2010. p. 149.

BARROS, S. G. de. A política nacional de luta contra a aids e o espaço aids no Brasil. 2013. 274 f. Tese (Doutorado em Saúde Pública) - Instituto de Saúde Coletiva, Universidade Federal da Bahia, Salvador, 2013. 
Renato Girade

Nasceu em 1972, em Brasília. Filho de médico pediatra e de uma pedagoga, cursou o ensino médio em Brasília. É tecnólogo em Processamento de dados, com espacialização em informação e informática em Saúde. Sua relação com a aids iniciou-se quando entrou no Programa Nacional de DST/Aids em 1993, através de um processo seletivo para secretário e fez sua trajetória profissional dentro do Programa Nacional. Um pouco antes de se formar foi para a área de tecnologia da informação. Trabalhou em quase todas as áreas do setor, assistência técnica, programador, analista de rede. Em seguida foi para a área de planejamento, onde permaneceu por cerca de dois anos e meio, três anos. Retornou para área de tecnologia da informação (TI) e atualmente está na coordenação geral, que abrange orçamento, governança de TI, administração, logística. Atualmente também é consultor no Unaids.

\section{Referências}

BARROS, S. G. de. A política nacional de luta contra a aids e o espaço aids no Brasil. 2013. 274f. Tese (Doutorado em Saúde Pública) - Instituto de Saúde Coletiva, Universidade Federal da Bahia, Salvador, 2013. 
Nasceu em 1954, em São Paulo. Filha de um administrador de empresas de uma multinacional, e de uma professora, Silvia cursou o ensino médico em escola particular. Em 1973 iniciou a graduação em Psicologia na PUC-RJ, concluída em 1978. Em seguida fez o mestrado (1979-1982) em Psicologia Clínica na mesma instituição, com o trabalho "A psicologia sobe o morro: psicólogos trabalhando em favelas no Rio de Janeiro", sob a orientação de Ana Maria Ribeiro Coutinho. Estava cursando o doutorado em Ciência Política no Instituto Universitário de Pesquisa do Rio de Janeiro (IUPERJ) quando recebeu a proposta de Betinho para colocar em pé uma instituição de luta contra a aids. Naquela época, ainda não tinha um nome definido. A ideia era fundar uma fundação que seria uma sucursal da International Interdisciplinary Aids Foundation (IIAF). Devido às dificuldades impostas pela legislação brasileira, resolveram criar uma associação, a Abia. Silvia ficou responsável pela formalização da instituição, através de um contrato de risco com Betinho: a mesma seria remunerada a partir do primeiro financiamento. Silvia tornou-se um quadro intermediário da associação, foi diretora executiva, de modo que fez uma trajetória profissional ao interior do subespaço militante, permanecendo na associação entre 1986 e 1990. Saiu porque achava que havia cumprido um ciclo, mas também devido a uma briga com outros membros da Abia. Foi coordenadora do convênio Fiocruz-Faperj na Fundação Carlos Chagas Filho de Amparo à Pesquisa do Estado do Rio de Janeiro (Faperj) entre 1994 e 2000. Entre 1999 e 2000, foi subsecretária adjunta de Segurança Pública do estado do Rio de Janeiro. Desde 2000 é pesquisadora do Centro de Estudos de Segurança e Cidadania da Universidade Cândido Mendes. Fez doutorado em Saúde Pública (2004-2007) na ENSP-Fiocruz, defendendo a tese Respostas brasileiras à violência no campo da segurança pública os movimentos sociais e as organizações não governamentais sob aorientação 
de Maria Cecília Minayo. Tem 22 artigos publicados, 11 livros publicados ou editados, 18 capítulos de livros, principalmente relacionadas ao tema violência urbana e segurança.

\section{Referências}

BARROS, S. G. de. A política nacional de luta contra a aids e o espaço aids no Brasil. 2013.274 f. Tese (Doutorado em Saúde Pública) - Instituto de Saúde Coletiva, Universidade Federal da Bahia, Salvador, 2013.

SOUZA, S. R. de. Currículo do sistema Currículo Lattes. [S.1.], 2011. Disponível em: <http://lattes.cnpq.br/0112749042532967>. Acesso em: 8 jun. 2011. 
Natural da cidade do Rio de Janeiro, filha de um contador e uma professora primária, cursou o ensino médio no Colégio Aplicação da UERJ, era um curso profissionalizante. Entre as possibilidades que tinha, resolveu fazer análises clínicas. Foi durante o curso que se decidiu pela medicina, sob a influência de um professor cujo grande sonho era ter sido médico e que convidava seus ex-alunos médicos para dar aulas, de modo que Valdiléa foi se encantando pela medicina. Fez a graduação em medicina na UERJ (1980-1985). No segundo ano da faculdade, em 1981, gostou da disciplina de Parasitologia e permaneceu como monitora, quando começou a se envolver com pesquisa. O coordenador da Parasitologia era Homero Salazar, mas Valdiléa trabalhava principalmente com Nilceia Freire, José Roberto Machado e Hércules de Moura. Foi a partir dessa experiência que resolveu seguir a infectologia. Fez Residência médica em Doenças Infecciosas e Parasitárias no Instituto de Infectologia Emílio Ribas (19861988). Quando decidiu seguir infectologia, não queria trabalhar com doenças crônicas, queria trabalhar com doenças curáveis, diz que, com a aids, caiu no oposto. Fez mestrado em Doenças Infecciosas e Parasitárias (1992-1995) na UFRJ, e Doutorado (2000-2008) em Saúde Pública na ENSP-Fiocruz, em ambos os cursos os trabalhos de conclusão estavam relacionados a HIV/aids. No mestrado trabalhou com tuberculose em pacientes HIV positivos e no doutorado com a prevenção da transmissão vertical. De 1989 a 1993, foi médica do serviço de DIP da UFRJ. Desde 1989 é pesquisadora da Fiocruz. Desde 1996 é membro do Comitê técnico assessor para terapia antirretroviral em adultos do Ministério da Saúde. Entre 1996 e 2000, participou também do Comitê técnico assessor para terapia antirretroviral em crianças. De 1997 a 2000 foi chefe da Unidade de Assistência do PN DST/Aids. Entre 2000 e 2003 foi Coordenadora do Programa Estadual de DST/Aids do Rio de Janeiro. Em 2006 assumiu a 
direção do Instituto de Pesquisa Clínica Evandro Chagas (IPEC/Fiocruz). É consultora do Ministério da Saúde. Tem 48 artigos publicados e três capítulos de livro.

\section{Referências}

BARROS, S. G. de. A política nacional de luta contra a aids e o espaço aids no Brasil. 2013. 274f. Tese (Doutorado em Saúde Pública) - Instituto de Saúde Coletiva, Universidade Federal da Bahia, Salvador, 2013.

SANTOS, V. G. V. dos. Currículo do sistema Currículo Lattes. [S.1.], 2011. Disponível em: <http://attes.cnpq.br/6266684004174408>. Acesso em: 17 maio 2011. 


\section{Valéria Petri}

Nasceu em $1^{\circ}$ de dezembro de 1947. O pai era funcionário da limpeza do Banco de Brasil e vendia materiais de encanamento. A mãe era dona de casa. Cursou o ensino médio em sistema de internato, no Colégio Koelle, em Rio Claro. Cursou Medicina na Escola Paulista de Medicina, entre 1968 e 1973. Em 1976, obteve o título de especialista em Dermatologia pela Sociedade Brasileira de Dermatologia. Fez mestrado em microbiologia e imunologia (1980-1981) e doutorado (1981-1982) em Dermatologia na mesma instituição. É livre-docente pela Unifesp (1992) e professora titular da Unifesp desde 1996. Identificou os primeiros casos de aids no país. Fez parte do grupo que participou da reunião com o Secretário de Saúde do estado de São Paulo, João Yunes, que demandou a atuação do Estado frente à epidemia de aids. Foi representante do Ministério da Saúde no primeiro meeting de aids, na OPAS, em Washington (EUA). Sua participação política sempre foi de bastidores, fazendo cartazes, escrevendo textos, por implicância do marido que não deixava que participasse mais ativamente. Desde 1975, é docente da Unifesp. Afastou-se da área de aids e hoje dedica-se à dermatologia. Realiza pesquisa clínico-dermatológica vinculada às áreas de Bioquímica, Farmacologia e Biofísica. É orientadora de mestrado e doutorado.

\section{Referências:}

ABBADE, Á. C. da S.; BAIÃO, F. (Org.). 100 nomes que fizeram a história da luta contra a aids no Brasil. São Paulo: GAPA BR SP, 2010. p. 187.

BARROS, S. G. de. A política nacional de luta contra a aids e o espaço aids no Brasil. 2013.274 f. Tese (Doutorado em Saúde Pública) - Instituto de Saúde Coletiva, Universidade Federal da Bahia, Salvador, 2013.

PETRI, V. Currículo do sistema Currículo Lattes. [S.1.], 2011. Disponível em: $<$ http://lattes.cnpq.br/8894929595866495>. Acesso em: 17 maio 2011. 
Vera é filha de Rubens Paiva, engenheiro civil e político desaparecido durante o regime militar. Sempre estudou em colégio de freiras. Vera queria mudar o mundo. Pensou em fazer diversos cursos: Ciências Sociais, Antropologia, História. Não queria medicina, pois achava que não aguentaria o curso e nem estava disposta aos sacrifícios para entrar em um curso de medicina de uma universidade pública, nem poderia pagar, visto a difícil situação da família, com seu pai desaparecido e sua mãe tendo que sustentar a casa e os cinco filhos. Para cursar a universidade tinha que ser em uma universidade pública e tinha que ser rápido. Decidiu fazer Psicologia. Fez a graduação na USP (1973-1977). Vera lutou contra a ditadura, era militante estudantil, foi fundadora do movimento brasileiro pela anistia. Participou ativamente de uma ONG feminista no início da década de 1970. Fundou o primeiro DCE no Brasil. Participou da reconstrução da União Nacional dos Estudantes em 1979. Participou do movimento da reforma sanitária brasileira, mais relacionada à luta pela reforma antimanicomial. Passou a trabalhar como terapeuta. Fez especialização em Saúde Mental pela Faculdade de Saúde Pública da USP (1980) e mestrado em Psicologia Social (1983-1984). Vera era psicóloga, hippie, morava em comunidade e tinha vários amigos gays, que começaram a morrer. Começou a atender pessoas vivendo com HIV/aids e que tratavam pessoas vivendo com HIV/ aids, em 1984. Desde 1988 é docente do Departamento de Psicologia Social do Instituto de Psicologia da USP. Coordena estudos que abordam as relações de gênero, as sexualidades e a dimensão psicossocial de tecnologias para promoção da saúde, com foco na prevenção primária e secundária ao HIV e da aids. Fundou e é coordenadora do Núcleo de Estudos para a Prevenção da Aids (Nepaids-USP), grupo interdisciplinar que congrega professores de diversos departamentos da USP, de outras universidades e instituições públicas de pesquisa, alunos de graduação e pós graduação. 
Em 1991, coordenou o primeiro congresso da repercussão psicossocial da aids no Brasil na USP (Impacto psicossocial da epidemia da AIDS). Tem 59 artigos, quatro livros e 25 capítulos de livro publicados, além de diversos textos em jornais e trabalhos apresentados em congressos. Bolsista de Produtividade em Pesquisa do CNPq - Nível 1C.

\section{Referências}

BARROS, S. G. de. A política nacional de luta contra a aids e o espaço aids no Brasil. 2013. 274 f. Tese (Doutorado em Saúde Pública) - Instituto de Saúde Coletiva, Universidade Federal da Bahia, Salvador, 2013.

PAIVA, V. S. F. Currículo do sistema Currículo Lattes. [S.1.], 2011. Disponível em: <http://lattes.cnpq.br/8100923258337993>. Acesso em: 9 jun. 2011. 
Nasceu em Teresina, no Piauí, em 1961. Filho de militar, muito cedo saiu de Teresina e foi morar no Rio de Janeiro. De lá foi para o Rio Grande do Sul, onde morou em uma cidade pequena, perto da fronteira do país e sua vida foi praticamente dentro do quartel, morando em vila militar. Retornou na pré-adolescência para o Rio de Janeiro, de onde não saiu mais. Cursou o ensino médio no Colégio Militar no Rio de Janeiro. Em 1980, ingressou no curso de Psicologia da UERJ (1980-1985). Veriano era militante do movimento homossexual pela afirmação e liberação sexual, atuando no grupo Somos e Auê, no Rio de Janeiro. Com o início da epidemia da aids, vários amigos começaram a ficar doentes. Em 1984, um de seus amigos se contaminou e foi a óbito em 1986. Vários outros depois seguiram a mesma trajetória. Fez mestrado em Psicologia Clínica (19861989), na PUC-RJ, com uma dissertação sobre homossexualidade. Sua aproximação com a Abia começou através de Carmita, que estava fazendo um estudo sobre homossexualidade e aids e sabia que Veriano tinha muitos relatos etnográficos. Quando chegou na Abia, Herbert Daniel estava fundando o grupo Pela Vidda, um grupo de pessoas soropositivas, não exclusivamente, e Veriano se aproximou. Em maio de 1989 iniciou como funcionário da Abia, onde continua atuando e desde 2001 é coordenador geral. Coordenou diversos projetos na Abia. Fez doutorado em Saúde Coletiva na UERJ (1993-1997), abordando a homossexualidade e a aids, sob a orientação de Richard Parker. Entre 2002 e 2004 foi professor visitante na UFRGS.

\section{Referências}

ABBADE, Á. C. da S.; BAIÃO, F. (Org.). 100 nomes que fizeram a história da luta contra a aids no Brasil. São Paulo: GAPA BR SP, 2010. p. 189. 
BARROS, S. G. de. A política nacional de luta contra a aids e o espaço aids no Brasil. 2013. 274 f. Tese (Doutorado em Saúde Pública) - Instituto de Saúde Coletiva, Universidade Federal da Bahia, Salvador, 2013.

TERTO JUNIOR, V. de S. Currículo do sistema Currículo Lattes. [S.1.], 2011. Disponível em: <http://lattes.cnpq.br/9164291927172325>. Acesso em: 9 jun. 2011. 


\section{APÊNDICE C \\ Concepções acerca do conceito de homens que fazem sexo com homens}

Continua

\begin{tabular}{|c|c|c|}
\hline $\begin{array}{l}\text { Campo/ } \\
\text { Espaço }\end{array}$ & Agente & Conceito HSH \\
\hline \multirow[t]{3}{*}{ Científico } & E16 & $\begin{array}{l}\text { Esse é um termo que vem dos Estados Unidos e é muito da saúde pública, por entender que vários } \\
\text { homens que se identificam nas suas práticas sexuais como héteros, eles têm relações com outros } \\
\text { homens e não se identificam nem como homo, nem como bi, eles se identificam como hétero. Então, } \\
\text { como incluir essas pessoas na prevenção? [...] Se a gente esta fazendo políticas públicas de saúde, } \\
\text { se a gente esta falando de saúde coletiva, temos que ampliar a base para prevenção. [...] e que hoje } \\
\text { algumas pessoas falam em chamar de "gays, bissexuais, e outros HSH". Até isso tem sido usado, } \\
\text { porque o movimento gay afirma que a identificação gay [...], ela é política e ela é importante [...] E } \\
\text { para prevenção [...], a mensagem seria um pouco diferente. }\end{array}$ \\
\hline & E19 & $\begin{array}{l}\text { [...] eu aprendi que não é só politicamente correto dizer homens que fazem sexo com homens ao } \\
\text { invés de homo ou bissexuais e sim porque eu recrutava caminhoneiros por exemplo. Vai dizer para } \\
\text { um caminhoneiro, ele é tão macho que come até viado na estrada, vai dizer para ele que ele é } \\
\text { homossexual. Então, homem que faz sexo com homem, não necessariamente entrar na sigla de ser } \\
\text { um gay. Eram só homo e bissexuais. }\end{array}$ \\
\hline & E25 & $\begin{array}{l}\text { Eu acho que ele tem potencialidade que ele inclui pessoas que não se vêem como homossexuais. Por } \\
\text { outro lado ele tem limitações, porque as seletivas não se incluem nesses temas.[...] Eu não sei quem } \\
\text { desenvolveu, mas quem traz para cá é o pessoal da Abia, em geral. Que é tudo fruto dos estudos sobre } \\
\text { homossexuais do Peter Fry e do Edward [MacRae]que vai ver essas relações no Brasil, como é que a } \\
\text { cultura popular daqui lida com isso. }\end{array}$ \\
\hline \multirow[t]{2}{*}{ Médico } & $E 23$ & $\begin{array}{l}\text { [...] são pessoas que não tem a identidade com o movimento homossexual, com a identidade gay, } \\
\text { mas tem relações homoeróticas. E o problema dessas pessoas é que elas não se enxergam sob risco. } \\
\text { Na medida em que você só coloca homossexual e você não fala de homem que faz sexo com homem, } \\
\text { você está tirando do grupo de risco, do comportamento de risco, essa relação sem identificação. } \\
\text { Então eu acho que o benefício que tem essa nomenclatura é isso, é colocar pessoas que não se auto- } \\
\text { identificam como passíveis de se contaminar. }\end{array}$ \\
\hline & E31 & $\begin{array}{l}\text { [...] eu acho que às vezes se perde muito tempo nessas questões. Mas no final elas tem a questão } \\
\text { da identificação. Se você refere com o termo errado, faz uma pergunta... principalmente quando a } \\
\text { gente está estudando comportamento. Eu acho que é um desafio hoje, na questão da prevenção, você } \\
\text { conseguir mapear isso [...] Se você faz a pergunta errada pode ser um problema. }\end{array}$ \\
\hline Burocrático & E2 & $\begin{array}{l}\text { [...] o machão brasileiro acha que o homem só é considerado homossexual se ele for passivo durante a } \\
\text { relação sexual, [...] então essa ideia de homens que fazem sexo com homens,[...] é para desconstruir } \\
\text { essa ideia que é muito forte no imaginário, por exemplo, um homem casado que se relaciona com } \\
\text { outro homem, mas que sempre assume digamos, sei lá, que ele acha que está assumindo uma } \\
\text { posição muito, entre aspas, ativa na relação sexual, ele acha que não é homossexual e acha que não } \\
\text { tem risco e acha que não precisa usar preservativo com a mulher. }\end{array}$ \\
\hline
\end{tabular}




\begin{tabular}{|c|c|c|}
\hline $\begin{array}{l}\text { Campo/ } \\
\text { Espaço }\end{array}$ & Agente & Conceito HSH \\
\hline \multirow[t]{4}{*}{$\begin{array}{l}\text { Espaço } \\
\text { Militante }\end{array}$} & E12 & $\begin{array}{l}\text { Tem-se muita dificuldade em fazer campanhas especificas para gay, porque começou a partir daí a } \\
\text { ter uma compreensão muito grande que tu não fala apenas para o gay, você fala para o gay, para } 0 \\
\text { travesti, para o transexual, para o homem que faz sexo com homem que se diz não gay. Isso abriu } \\
\text { um leque de linguagens entre o movimento. No momento falava viado, bicha e hoje você fala HSH, } \\
\text { que engloba tudo. [...] que são homens que fazem sexo com homens mas [...] que não se auto } \\
\text { denominam gays. [...] que poderia ser até bissexual, no caso, que não se define como homossexual, } \\
\text { mas que teria práticas homossexuais. }\end{array}$ \\
\hline & E14 & $\begin{array}{l}\text { A gente passou por um período no movimento de aids, que a gente começou a entrar nessa dinâmica } \\
\text { de querer mudar as terminologias, as palavras, porque as palavras poderiam carregar consigo o } \\
\text { preconceito, o estigma e também fechar determinados grupos quando você não se sentia parte } \\
\text { daquele grupo, você poderia também não se sentir vulnerável e não exercer a sexualidade mais } \\
\text { segura, responsável e com a prevenção. Então, para os homossexuais foi HSH, para as prostitutas } \\
\text { trabalhadoras sexuais, e população que antes era só gays agora é LGBTs que é enorme... Com tantas } \\
\text { siglas, tantas letras, e depois houve todo um retrocesso, um retrocesso não, um repensar nisso e a } \\
\text { população gay passou a deixar de lado, os profissionais que trabalham com aids deixaram de lado o } \\
\text { HSH e voltaram a falar população gay. As prostitutas não queriam usar mais o termo trabalhadoras } \\
\text { sexuais e sim prostitutas, porque há uma força política nisso também, construção de identidade }\end{array}$ \\
\hline & E20 & $\begin{array}{l}\text { [...] uma despolitização da homossexualidade. Nós consideramos que mesmo aqueles indivíduos, } \\
\text { eu já escrevi isso: HSH, um conceito equivocado epidemiologicamente e politicamente, porque o } \\
\text { machão, o bissexual que transa com o travesti ou com a bicha, ele não considera que seu parceiro } \\
\text { é um homem. É uma bicha ou uma travesti. E ele próprio, embora não se considere homossexual, } \\
\text { ele tem a consciência de que ele está praticando um ato homossexual. A categoria HSH não ajuda } \\
\text { ninguém, nem a prevenção junto aos próprios bissexuais, nem aos próprios bichas e travestis que } \\
\text { não se consideram homens muitas delas, de modo que nós protestamos e que até hoje ainda existe } \\
\text { alguém que defenda, mas é uma forma equivocada como a experiência demonstrou. }\end{array}$ \\
\hline & E33 & $\begin{array}{l}\text { A gente aqui da Abia foi acusada de embates e confusões com o Mott como se a gente quisesse } \\
\text { desmobilizar a identidade política proposta pelos grupos gays organizados. E na verdade não tem } \\
\text { nada disso porque a gente usa em geral HSH e gay indiscriminadamente. A gente usa até HSH, gay, } \\
\text { homossexuais, depende de como as pessoas se identifiquem. A gente não pode negar que existe um } \\
\text { mundo de homens que tem uma prática homossexual e que não tem uma identidade homossexual. } \\
\text { Não somos nós que vamos dizer que eles são gays não assumidos. Se o movimento homossexual } \\
\text { queira classificar assim é legítimo. Eu mesmo pessoalmente posso achar isso, mas eu não posso } \\
\text { dentro de um programa de prevenção da aids achar essas coisas. Eu tenho que trabalhar com essas } \\
\text { diferenças e com um relato do que as pessoas falam. É uma categoria complicada, eu admito, } \\
\text { politicamente [...], mas por outro lado dá conta de uma série de diferenças que existem dentro } \\
\text { das relações homossexuais e que precisam ser consideradas no trabalho de prevenção. Mas é uma } \\
\text { categoria complicada, sem dúvida. }\end{array}$ \\
\hline
\end{tabular}




\section{APÊNDICE D}

Concepções dos agentes acerca do significado dos acordos de empréstimo junto ao Banco Mundial para a política nacional de controle da aids 


\begin{tabular}{|c|c|c|c|}
\hline SE & Agente & Concepções & Trecho \\
\hline & E1 & $\begin{array}{l}\text { Estruturação do PN } \\
\text {-melhoria } \\
\text { da gestão } \\
\text { (transferência } \\
\text { de recursos } \\
\text { para Estados e } \\
\text { municípios); } \\
\text { - inquéritos } \\
\text { - Financiamento de } \\
\text { projetos de 0NGs }\end{array}$ & $\begin{array}{l}\text { "[...] já tem uma capacidade normativa, de conhecimento, já começam a adquirir capacidade } \\
\text { normativa e vai dar o salto final com o acordo de empréstimo que começa em } 92 \text {. Aí com } \\
\text { isso o programa nacional também adquire capacidade de indução de política por meio de } \\
\text { financiamento. [...] Melhora muito a interlocução com a sociedade civil. [...] Sinceramente, } \\
\text { eu acho que não existira na configuração que existe hoje programa nacional, se não tivesse o } \\
\text { acordo de empréstimo [...] Não é pelo volume de recurso, mas é pelo papel que esses recursos } \\
\text { desempenham na política nacional. A primeira questão [...] é a contratação de uma equipe } \\
\text { técnica de alto nível [...] A segunda questão é que ele permite financiar áreas que não eram } \\
\text { financiadas regularmente pelo sistema de saúde. [...] o financiamento da melhoria da gestão } \\
\text { no âmbito dos estados e municípios. [...] E ao mesmo tempo ele financia as ONGs. [...] E tem } \\
\text { um terceiro aspecto, [...] que é da produção do conhecimento, especialmente, na área da } \\
\text { Vigilância Epidemiológica. Então começam a se desenvolver os primeiros inquéritos nacionais, } \\
\text { quando se começa a dimensionar efetivamente e conhecer a epidemia que existe no país." }\end{array}$ \\
\hline & E15 & $\begin{array}{l}\text { Estruturação do PN } \\
\text { - Pesquisa } \\
\text { - Financiamento de } \\
\text { projetos de ONGS } \\
\text { Financiamento do } \\
\text { tratamento com } \\
\text { recursos da união }\end{array}$ & $\begin{array}{l}\text { "Nossa foi um avanço muito grande, foi uma coisa muito grande, porque o custo hoje de } \\
\text { tudo que se trabalha com DST/Aids é muito caro. Então, o recurso que a gente tem hoje } \\
\text { do ministério da saúde, recursos da união, é praticamente para compra de medicamentos, } \\
\text { e quando você tem um acordo de empréstimo, você passa a financiar projetos. Teve } \\
\text { financiamento de projetos de vacina, projetos de pesquisa, ações que movimentos sociais } \\
\text { fazem." }\end{array}$ \\
\hline & E17 & $\begin{array}{l}\text { Estruturação do PN } \\
\text { - Consolidou } \\
\text { uma estrutura } \\
\text { programática } \\
\text { - Priorização } \\
\text { de populações } \\
\text { vulneraveis } \\
\text { Registro da } \\
\text { manutenção } \\
\text { da autonomia } \\
\text { nacional }\end{array}$ & $\begin{array}{l}\text { "[...] você consolidou uma estrutura programática no país com os dois primeiros } \\
\text { financiamentos do Banco Mundial." } \\
\text { "Antes disso tem um debate importante que é o debate provocado pelo Banco Mundial } \\
\text { que tenta induzir as políticas públicas dos países. E induzir sob a perspectiva que se deva } \\
\text { centrar e se concentrar as ações da prevenção, não olhar pra questão do investimento em } \\
\text { tratamento[...] E, dentro da prevenção, se concentrar nos grupos e populações de maior } \\
\text { risco. Essa era a tese do Banco Mundial que prevaleceu durante os anos noventa, do qual } \\
\text { o Brasil refutou. } 0 \text { Brasil não concordava. Concordava com a necessidade de aportar mais } \\
\text { recursos pra prevenção, mas não dissociar essas ações do campo do tratamento. Então, } \\
\text { tratamento e prevenção tinham que caminhar de braço dados, juntos como uma estratégia } \\
\text { pra enfrentamento da epidemia." }\end{array}$ \\
\hline & E21 & $\begin{array}{l}\text { Viabilidade do PN } \\
\text { - Consolidação das } \\
\text { ONGs } \\
\text { - Expansão do } \\
\text { número de ONGs }\end{array}$ & $\begin{array}{l}\text { "Tudo. [...] o primeiro foi a manutenção do programa, o segundo que foi a questão do sangue } \\
\text { [...] E também a questão de consolidar as ONGs, os repasses para as ONGs. Foi o boom de } \\
\text { repasse para as ONGs. Eu lembro que eu que tomava conta da unidade, eu já trabalhei em } \\
\text { tudo aqui. A questão dos projeto, das ONGs era comigo, então tinha cerca de } 3 \text { mil projetos } \\
\text { firmados com ONGs. Então foi o boom de criação de ONG do país, tanto da parte de prevenção } \\
\text { como de assistência, também de drogas injetáveis, essas coisas, que era uma das populaçôes } \\
\text { que mais se contaminavam. Então, esses dois acordos de empréstimos propiciaram vários } \\
\text { convênios com ONGs. [...]" }\end{array}$ \\
\hline & E23 & $\begin{array}{l}\text { Estruturação do PN } \\
\text { - Controle da } \\
\text { epidemia }\end{array}$ & $\begin{array}{l}\text { "Eles foram fundamentais na época. Não acompanho hoje, mas se realmente se a gente não } \\
\text { tivesse tido esse dinheiro extra, esse aporte de recurso, a gente não teria o controle que a } \\
\text { gente tem hoje, mesmo que a gente não tenha o controle total, mas não pode se comparar } \\
\text { com os países como a África e tudo, que eu tive oportunidade de ver. Era uma calamidade } \\
\text { pública mesmo, [...] então eu acho que os acordos e tal foram fundamentais mesmo. Eu acho } \\
\text { que o Brasil soube aplicar bem nesse particular. Realmente as estatísticas que mostravam as } \\
\text { projeções na realidade de que se não houvesse } 0 \text { acordo os números seriam absurdos..." }\end{array}$ \\
\hline 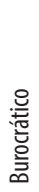 & E28 & $\begin{array}{l}\text { Estruturação do PN } \\
\text { - Estruturação } \\
\text { material do } \\
\text { programa } \\
\text { (aquisição } \\
\text { equipamentos) }\end{array}$ & $\begin{array}{l}\text { "[...] a gente não tinha quase nada, computador tinha muito poucos, aí já com o acordo } \\
\text { que a gente começou a ter a possibilidade de comprar, fora Ministério. Aí era a questão de } \\
\text { equipar, estruturar mesmo, na época o programa era coordenação nacional. Aí começou toda a } \\
\text { questão estrutural mesmo de infra estrutura tecnológica, comprar computador, ver a questão } \\
\text { de impressora[...] começou a estruturar e aí depois de começar a estruturar aqui, a gente } \\
\text { começou a estruturar também a questão dos estados e municípios." }\end{array}$ \\
\hline
\end{tabular}




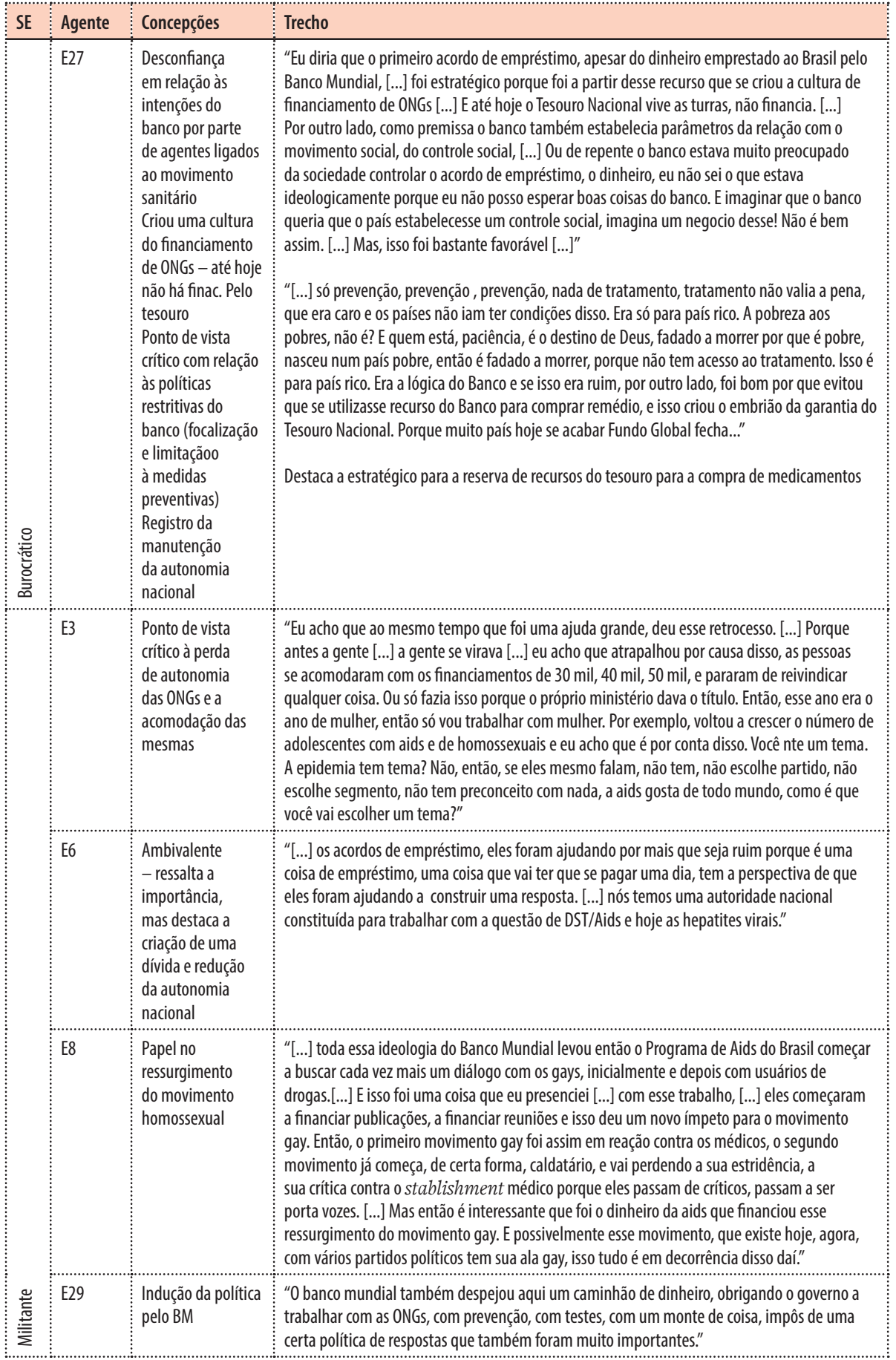




\begin{tabular}{|c|c|c|c|}
\hline SE & Agente & Concepções & Trecho \\
\hline & E12 & $\begin{array}{l}\text { Indução do } \\
\text { crescimento do } \\
\text { número de 0NGs } \\
\text { Crítica à forma de } \\
\text { financiamento das } \\
\text { ONGs (projeto) }\end{array}$ & $\begin{array}{l}\text { "Eu acompanhei bem essa chegada do Bird o que modificou todo o panorama da epidemia } \\
\text { da aids sem sombra de duvidas, o financiamento internacional. [...] ele representou o grande } \\
\text { crescimento das ONGs como um todo no país. [...] Se trabalha por projeto. Se tem uma } \\
\text { ditadura do projeto nessa época." }\end{array}$ \\
\hline & E13 & $\begin{array}{l}\text { Estruturação do PN } \\
\text { - melhoria da rede } \\
\text {-melhoria da } \\
\text { governança } \\
\text { Fortalecimento } \\
\text { das ONGs, } \\
\text { possibilitando } \\
\text { controle social }\end{array}$ & $\begin{array}{l}\text { "Hoje nós temos o último acordo, que é de } 200 \text { milhões de dólares, grande parte desse } \\
\text { recurso é do tesouro nacional, então, eu acho que na medida que você tiver isso garantido } \\
\text { com recursos do fundo, mas sem dúvida nenhuma, eles são importantes, são importantes } \\
\text { acho que pra você melhorar a rede, pra você melhorar a governança, pro fortalecimento das } \\
\text { organizações não governamentais, o terceiro setor passa por uma crise de desfinanciamento, } \\
\text { isso é fato, e a gente precisa, e eu acho que esses acordos eles tem contribuído muito pra que a } \\
\text { gente continue passando esses recursos que são fundamentais, pra que as organizações atuem } \\
\text { de fato no seu papel que é o de fazer o controle social. Então eu acho que são de extrema } \\
\text { importância." }\end{array}$ \\
\hline & E14 & $\begin{array}{l}\text { Estruturação do PN } \\
\text { - Possibilidade de } \\
\text { captação de bons } \\
\text { profissionais } \\
\text { Financiamento de } \\
\text { ONGs } \\
\text { Fragilização das } \\
\text { ONGs }\end{array}$ & $\begin{array}{l}\text { "[...] quando o acordo de empréstimo cria o departamento de uma forma com uma } \\
\text { magnitude maior, um grupo maior de profissionais trabalhando, o Estado termina } \\
\text { aproveitando e trazendo para si, muitos profissionais que estavam dentro das ONGs. Então não } \\
\text { só por essas, não sei se a palavra mais apropriada é essa, cooptação, mas as ONGs se sentiram } \\
\text { fragilizadas porque tinham o Estado financiando, mas também, porque perderam seus líderes } \\
\text { para o plano federal o Programa Nacional de aids que chamavam eles oferecendo cargos } \\
\text { políticos no Programa Nacional." }\end{array}$ \\
\hline & E18 & $\begin{array}{l}\text { Estruturação do PN } \\
\text { - melhoria relativa } \\
\text { da gestão } \\
\text { Indução do } \\
\text { crescimento do } \\
\text { número de ONGs }\end{array}$ & $\begin{array}{l}\text { "Eu acho, que digamos para o Brasil inteiro, significou alguma coisa. Porque era a } \\
\text { disponibilidade de um dinheiro de gerenciamento mas... Veja só, a maior parte do dinheiro, } \\
\text { maior em si, pelo menos } 80 \% \text {, às vezes até mais, era para a gestão pública. Isso permitia uma } \\
\text { espécie de "azeitamento" da gestão pública que de outra forma não conseguiria, então para } \\
\text { conseguir mais rapidamente, para conseguir fazer reuniões, para fazer viagens ou inclusive } \\
\text { para projetos de prevenção. Isso facilitou a gestão. Apesar de que, segundo os gestores, era } \\
\text { um dinheiro que facilitou, mas não substituiu. Não é que substituiu a gestão no sentido de } \\
\text { pagamento de enfermeiros, de leito de pessoal, de remédios [...]" } \\
\text { "[...] teve uma facilidade de acesso a fundos por parte das ONGs brasileiras, que antes não } \\
\text { tinha. Isso também levou à fundação de várias ONGs." }\end{array}$ \\
\hline & E22 & $\begin{array}{l}\text { Ruptura - nova } \\
\text { fase da PN } \\
\text { Articulação entre } \\
\text { governo e ativistas }\end{array}$ & $\begin{array}{l}\text { "[...] mudou a face do trabalho em aids no Brasil todo, é um marco divisor. [...] se não } \\
\text { houvesse essa proposta e de também trazer recursos humanos e militantes ativistas para } \\
\text { dentro do da estrutura ministerial a epidemia hoje podia estar sendo tratada de uma forma } \\
\text { completamente diferente. Então eu acho que também não é uma decisão fácil para o gestor } \\
\text { trazer propostas chaves se por um lado facilita o diálogo, complica todas essas coisas, mas } \\
\text { por outro lado também você traz um arsenal de pessoas que de alguma forma também tem } \\
\text { comprometimento ainda com suas origens de movimentos, então você cria um campo de } \\
\text { tensão permanente no seu ambiente de trabalho, produtivo, mais um campo de tensões } \\
\text { permanente." }\end{array}$ \\
\hline 壱 & E33 & $\begin{array}{l}\text { Ruptura - nova } \\
\text { fase da PN } \\
\text { Estruturação do PN } \\
\text { Financiamento de } \\
\text { ONGs, levando a } \\
\text { uma atenuação da } \\
\text { crítica } \\
\text { Articulação entre } \\
\text { governo e ativistas }\end{array}$ & $\begin{array}{l}\text { "0 empréstimo do banco mundial realmente foi a mudança mesmo. Não que não tivesse } \\
\text { um programa de aids no Brasil, mas o que estrutura mesmo é o empréstimo com o banco } \\
\text { mundial. É se preparar para esse empréstimo e o próprio impacto do empréstimo na } \\
\text { organização do programa. Entende. É o grande divisor de águas. [...] Foi o que permitiu } \\
\text { estruturar o programa. [...] } 0 \text { banco exige que nesses projetos sociais tenha um dialogo com } \\
\text { a sociedade civil. E isso, talvez por pressão do próprio banco, o governo muda sua posição } \\
\text { de fechamento com a sociedade civil e procura abrir diálogo. [...] Esse projeto do banco ele } \\
\text { inaugura, um canal sistematizado, organizado de financiamento da sociedade civil. Aquela } \\
\text { relação de oposição frontal, só de crítica em relação ao governo federal pelo menos, ela muda } \\
\text { para ser uma relação de, sim ainda crítica mas muito mais companheira, de uma certa forma, } \\
\text { de mais colaboração." }\end{array}$ \\
\hline
\end{tabular}




\begin{tabular}{|c|c|c|c|}
\hline SE & Agente & Concepções & Trecho \\
\hline & E9 & $\begin{array}{l}\text { Estruturação do PN } \\
\text { - contratação de } \\
\text { técnicos } \\
\text { Registra a } \\
\text { manutenção } \\
\text { da autonomia } \\
\text { nacional no } \\
\text { que toca aos } \\
\text { medicamentos } \\
\text { Financiamento de } \\
\text { pesquisas } \\
\text { Financiamento } \\
\text { proj. ONGs }\end{array}$ & $\begin{array}{l}\text { "Foi um aporte para o programa muito grande. Poder contratar técnicos, financiar pesquisas } \\
\text { etc. E tudo. E para as ONGs, um componente importante é o de apoio para projetos de ONGs, } \\
\text { não só de auxilio para encontros, mas para casas de apoio e muito mais. Por sinal, tinha } \\
\text { técnicos do Banco que dizia que era uma tentativa da Lair querer cooptar a sociedade civil, } \\
\text { não sabiam eles que seria com prestação de contas, processo competitivo e tudo." } \\
\text { "[...] o Banco Mundial nunca aceitou a gente comprar medicamento, e, quando a gente } \\
\text { começou a usar antirretroviral, antes da lei chamada Lei Sarney, membros do staff da OMS } \\
\text { disseram que nós não íamos manter a distribuição gratuita e que íamos criar cepas circulantes } \\
\text { resistentes aos antirretrovirais. Já no Banco Mundial, o discurso era de que não iríamos } \\
\text { conseguir manter essa distribuição universal e gratuita, e iríamos focalizar, em fazendo assim, } \\
\text { mais no tratamento do que na prevenção. O Banco Mundial sempre foi contra. Atualmente } \\
\text { eles reconhecem que deu certo" }\end{array}$ \\
\hline & E16 & $\begin{array}{l}\text { Viabilidade de } \\
\text { execução da } \\
\text { política } \\
\text { Financiamento de } \\
\text { projetos } \\
\text { Sustentabilidade } \\
\text { das ONGs } \\
\text { Destaca a criação } \\
\text { de uma dívida } \\
\text { como ponto } \\
\text { negativo }\end{array}$ & $\begin{array}{l}\text { "Eles representaram e representam ainda hoje a execução da política. Eles representaram } \\
\text { a possibilidade de ter financiamento de projetos de diversas áreas, eles representaram a } \\
\text { sustentabilidade de ONGs e a criação de ONGs e de movimentos sociais durante muitos anos. } \\
\text { [...] eu acho que o recurso do acordo, há muita crítica porque o país paga, o país de fato tem } \\
\text { que pagar essa divida [...] os empréstimos vem diminuindo ao longo do tempo, mas eu acho } \\
\text { que existe indicadores de que ele de fato foi usado de uma forma, que hoje a gente tem } \\
\text { resultados positivos em varias áreas: capacidade instalada, formação de recurso, formação } \\
\text { de recursos humanos, no Brasil inteiro, nas mais diversas áreas, desde a área do cuidado, da } \\
\text { epidemiologia, a prevenção." }\end{array}$ \\
\hline & $\mathrm{E} 25$ & $\begin{array}{l}\text { Financiamento de } \\
\text { ONGs } \\
\text { Redução do papel } \\
\text { político das ONGs } \\
\text { - cooptaçãoo }\end{array}$ & $\begin{array}{l}\text { "[...] o movimento inicialmente era altamente contestador do Estado. Quando veio o } \\
\text { financiamento, quando eles compraram um fax. É uma coisa que muda! Um movimento que } \\
\text { tem um fax, naquela época não tinha muito e-mail assim, era uma forma de fazer política. } \\
\text { Aí aquele lado mais ácido da crítica da sociedade, das críticas das políticas do Estado mais } \\
\text { contestador, em } 92 \text { começa a fazer um realinhamento, uma cooptação das ONGs e elas perdem } \\
\text { essa capacidade, porque elas vivem se tornam co-responsáveis pela política. [...] Não quero } \\
\text { falar que é meramente uma cooptação porque teve um toma lá da cá, mas houve uma perda } \\
\text { de uma crítica mais ácida." }\end{array}$ \\
\hline & $\mathrm{E} 30$ & $\begin{array}{l}\text { Registro da } \\
\text { influência da } \\
\text { Reforma Sanitária } \\
\text { na manutenção } \\
\text { da autonomia } \\
\text { nacional }\end{array}$ & $\begin{array}{l}\text { "[...] a recomendação era prevenção, prevenção, prevenção. E o Brasil se descolou em parte, } \\
\text { quer dizer, em grande parte. Pela reforma sanitária, pela nossa constituição, pelos ideais de ter } \\
\text { um sistema de acesso universal e que se mostrou uma decisão mais do que acertada, não é?" }\end{array}$ \\
\hline 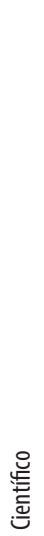 & $\mathrm{E} 32$ & $\begin{array}{l}\text { Registro da } \\
\text { manutenção } \\
\text { da autonomia } \\
\text { nacional em } \\
\text { diversos pontos } \\
\text { contrários à } \\
\text { política do BM } \\
\text { Reconhecimento } \\
\text { da importância da } \\
\text { contrapartida }\end{array}$ & $\begin{array}{l}\text { "[...] Eu participei do debate, da construção do primeiro acordo Brasil-Banco Mundial. } \\
\text { Participei do debate: [...] Para terceiro mundo só prevenção. Cuidado não, quer dizer, } \\
\text { tratamento não. [...] Eu acho que a interlocução com o Banco Mundial é importante num } \\
\text { padrão de autonomia, dignidade e liberdade do que é nossa política. E a defesa dos princípios } \\
\text { do SuS. Isso foi importante pra nós. Claro que por outro lado trouxe um monte de dinheiro } \\
\text { a mais, que obriga o Estado brasileiro a dar contrapartida. Mas do ponto de vista simbólico, } \\
\text { produção de política ideológica, etc. Eu acho que essa noção de autonomia nunca se perdeu. } \\
\text { Porque a gente enfrentou o Banco direto. Eu sei porque viajo muito, a maior parte dos países } \\
\text { 'abre as pernas' pra ter o dinheiro. Entendeu? E gente foi pescoçudo. [...] A coisa de centrar } \\
\text { na questão da discriminação, a coisa de apoiar a luta e as políticas anti-homofóbicas. A } \\
\text { questão de transitar do grupo de risco, da noção de risco para a vulnerabilidade, a questão de } \\
\text { trabalhar a prevenção em acordo, e trabalhando com as ONGs, a noção de participação do SUS } \\
\text { informando as políticas o tempo inteiro. Qualquer congresso de aids que você vai é assim, mas } \\
\text { no Brasil especialmente tem sempre assim: a academia, o governo e as ONGs. Isso se construiu } \\
\text { ali, isso estava presente ali. [...] A gente dependia de dinheiro externo, não tinha dinheiro } \\
\text { de orçamento. Foi difíil convencer os governos a incorporar a questão da aids. Então esse } \\
\text { dinheiro de financiamento externo é um dinheiro importante." }\end{array}$ \\
\hline
\end{tabular}




\section{APÊNDICE E \\ Concepções sobre a Comissão Nacional de Aids}

Continua

\begin{tabular}{|c|c|c|c|}
\hline Agente & Subespaço & Concepções & Trecho \\
\hline E1 & Burocrático & $\begin{array}{l}\text { Instância dotada de } \\
\text { representatividade e legitimidade, } \\
\text { com influência na tomada de } \\
\text { decisão na } 1^{\circledR} \text { fase }\end{array}$ & $\begin{array}{l}\text { "No momento inicial, a Cnaids desempenha um papel fundamental. } \\
\text { Talvez seja o maior limite de controle externo que tem o Ministério } \\
\text { da Saúde em relação à aids. Ele é dado não pelo papel de controle } \\
\text { social, que é dos Conselhos [de Saúde], mas ele é dado pela } \\
\text { excelência de seus membros. Então, consegue uma composição } \\
\text { no rol da Cnaids de muita legitimidade, de muito reconhecimento } \\
\text { político e consegue exercer uma influência, um limite, embora ele } \\
\text { nunca tenha sido um órgão de controle efetivamente." }\end{array}$ \\
\hline E3 & Militante & 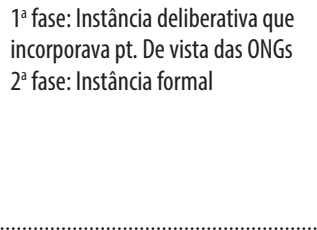 & $\begin{array}{l}\text { "Para ser sincera eu posso te dizer antes que a gente tinha voz. } \\
\text { Tinha voz e tinha propostas. Todas as vezes que ia para uma reunião } \\
\text { da Cnaids, o Gapa sentava antes, discutia os temas, o que ia ser } \\
\text { falado, como ia ser falado, a gente mesmo se questionava dias e } \\
\text { dias naquilo, então se levava quase que um documento pronto com } \\
\text { vários pontos já discutidos e debatidos. Agora, pelo que eu sei, a } \\
\text { coisa já vem pronta para você assinar. Aíjá não é o que era.[...]" }\end{array}$ \\
\hline E5 & Militante & Instância de assessoria técnica & $\begin{array}{l}\text { "[...] A Cnaids é uma instância importante como assessoria } \\
\text { técnica ao Programa de Aids, o Departamento agora, mas ela não } \\
\text { tem poder decisório, então, se você quiser interferir, tem uma } \\
\text { normativa, portaria do Ministério da Saúde ou não sei o que, } 0 \\
\text { Programa de Aids não tem autoridade pra fazer [...] a instância } \\
\text { formal é o Conselho Nacional de Saúde." }\end{array}$ \\
\hline E6 & Militante & $\begin{array}{l}\text { Instância consultiva com influência } \\
\text { na tomada de decisão }\end{array}$ & $\begin{array}{l}\text { "A Cnaids, eu acho que é a estrutura que a gente tem aqui como se } \\
\text { fosse o Conselho Nacional de Saúde. [...] Ela é o nosso maior canal } \\
\text { de escuta, e é o nosso canal maior de possibilidade de pactuações. } \\
\text { [...] Então, ela representa pra gente um espaço de consulta porque } \\
\text { lá é um espaço consultivo mas que ajuda na deliberação. [...] Ela é } \\
\text { consultiva, mas com grande potencial de influência dessas decisões } \\
\text { que são tomadas pelo departamento. [...] Então eu acho que ela } \\
\text { representa esse marco de referendo da comunidade e das políticas } \\
\text { que querem ser implementadas [...] ela funciona mesmo como se } \\
\text { fosse um controle social, muito semelhante a estrutura que a gente } \\
\text { tem no Conselho Nacional de Saúde." }\end{array}$ \\
\hline E9 & Científico & Instância de assessoria técnica & $\begin{array}{l}\text { "[...] A Comissão Nacional de Aids é a principal comissão } \\
\text { assessora..." }\end{array}$ \\
\hline E12 & Militante & Instância normalizadora na $1^{\text {a }}$ fase & $\begin{array}{l}\text { "Eu não sei nem como ela está funcionando hoje, mas era um } \\
\text { fórum de deliberações muito mais normativas do que propriamente } \\
\text { discutir a política. A partir daí se normatizava vários procedimentos, } \\
\text { a questão do teste, a questão dos medicamentos, a questão do } \\
\text { aconselhamento. Todas as questões passavam pela Cnaids. As } \\
\text { questões políticas, técnicas, passavam pela Cnaids. Era um fórum } \\
\text { planejado." }\end{array}$ \\
\hline
\end{tabular}




\begin{tabular}{|c|c|c|c|}
\hline Agente & Subespaço & Concepções & Trecho \\
\hline E11 & Burocrático & Instância consultiva & $\begin{array}{l}\text { "[...] a Cnaids é um fórum consultivo do Ministério Saúde onde } \\
\text { você engloba os vários elementos da sociedade: sociedade civil, } \\
\text { sociedade científica, sociedade médica, farmacêutica, forças } \\
\text { armadas. E que eles têm como função discutir, não aprovar. É } \\
\text { consultiva. E dar sugestões a política geral que se desenvolve } \\
\text { dentro do Programa de DST/Aids e hepatite virais. Então, é um } \\
\text { conselho consultivo no qual a gente apresenta a proposta e eles } \\
\text { sugerem, corrigem, modificam, mas sendo a última palavra sempre } \\
\text { do diretor do departamento, do Ministro." }\end{array}$ \\
\hline E13 & Militante & $\begin{array}{l}\text { Instância de validação, referendo } \\
\text { da política, com maior importância } \\
\text { na 1ª fase }\end{array}$ & $\begin{array}{l}\text { "[...] ela tem um papel fundamental porque ela é composta } \\
\text { não só de representantes da sociedade civil, mas de membros } \\
\text { da academia, de outros seguimentos do governo e eu acho que } \\
\text { ela teve, tem ainda, mais eu acho muito mais naquela época, é } \\
\text { uma comissão extremamente significativa até porque você tava } \\
\text { discutindo uma política e sendo referendada por essa comissão, } \\
\text { envolvendo outros setores da sociedade, como academia, conselho } \\
\text { de igrejas, enfim, outros ministérios e ela tentar segurar essa pauta } \\
\text { que extrapola as questões da saúde. A aids perpassa várias outras } \\
\text { questões, e eu acho que na medida que você tinha ali pessoas, } \\
\text { formadoras de opiniões, se posicionando a favor da manutenção } \\
\text { de uma política, que vem responder a uma epidemia, é ainda } \\
\text { muito calcada na questão do estigma, da discriminação, eu } \\
\text { acho que a Comissão Nacional de Aids é um marco importante, } \\
\text { referencial dessa história. Ela continua tendo esse papel, mas eu } \\
\text { acho que naquele momento, ela foi de extrema relevância pra } \\
\text { ser assegurado, pra avalizar tudo que tava sendo colocado, as } \\
\text { demandas trazidas pela sociedade civil, pela comunidade cientifica, } \\
\text { e eu acho que a comissão, ela tem um papel muito importante, que } \\
\text { é de validar. }\end{array}$ \\
\hline E15 & Burocrático & Instância de debate da política & $\begin{array}{l}\text { "[...] a Cnaids é minha comissão do coração. Ela começou porque } \\
\text { o programa nunca trabalhou sozinho, então a gente sempre } \\
\text { teve o trabalho em parceria com os Estados, com os municípios } \\
\text { e com movimento social, [...]. Então começou a fazer discussões, } \\
\text { a fazer reuniões para discutir metas e planos de ações do } \\
\text { departamento.[...] Ela começou acho que com } 10 \text { pessoas, com } \\
\text { infectologistas, dermatologistas, representação do movimento } \\
\text { social sempre tivemos, pessoas envolvidas com a causa. E cada } \\
\text { situação epidemiológica, você vai renovando e buscando o perfil } \\
\text { de composição. Hoje, ela está composta por } 40 \text { membros. Você } \\
\text { tem desde ministérios, sociedades civis, [...] ela é bem ampla. Ela } \\
\text { pega todos os pontos de interesse de toda uma ação conjunta. } \\
\text { [...] quem preside essa comissão, é a diretoria do departamento. } \\
\text { [...] a gente sempre teve autonomia para escolher os membros da } \\
\text { Cnaids. Muitos deles, por exemplo, de instituições, de sociedades de } \\
\text { saúde, são indicação das presidências. A gente solicita a indicação. } \\
0 \text { movimento social, a gente, naquela época, como ainda não tinha } \\
\text { um movimento fortalecido, o nível de escolha pela diretoria, eram } \\
\text { aquelas pessoas que tinham um trabalho social e de luta contra a } \\
\text { aids junto à comunidade, junto a sociedade civil com um ênfase e } \\
\text { um destaque maior." }\end{array}$ \\
\hline
\end{tabular}




\begin{tabular}{|c|c|c|c|}
\hline Agente & Subespaço & Concepções & Trecho \\
\hline E16 & Científico & $\begin{array}{l}\text { Instância de debate da política } \\
\text { Instância de controle social }\end{array}$ & $\begin{array}{l}\text { "Eu acho que ela tem um papel extremamente importante no } \\
\text { controle social, em poucas ocasiões você pode de fato visualizar um } \\
\text { comitê com tanta diversidade. Não são só acadêmicos, inclusive são } \\
\text { poucos acadêmicos, porque são indicados pelas suas instituições, } \\
\text { o movimento social tem um papel importante. [...] A fase inicial } \\
\text { [...] eram discussões muito diferentes das discussões que hoje a } \\
\text { gente tem com um Programa completamente consolidado, é muito } \\
\text { mais fácil. [...] Então, o diretor é assessorado, todas as decisões são } \\
\text { discutidas na Cnaids e muito discutidas, até a exaustão, às vezes." }\end{array}$ \\
\hline E21 & Burocrático & Instância consultiva & $\begin{array}{l}\text { "Ela é consultiva mesmo. Consultiva e propositiva também. [...] } \\
\text { Quando foi instituída ela foi importantíssima porque norteou } \\
\text { muita coisa. A questão dos medicamentos, a própria política } \\
\text { de medicamentos, que é o coquetel, e hoje tem um papel } \\
\text { importantíssimo ainda. Se reúne de três em três meses." }\end{array}$ \\
\hline E27 & Burocrático & $\begin{array}{l}\text { Instância de assessoria técnica e } \\
\text { política } \\
\text { Maior peso político na } 1^{\text {a }} \text { fase }\end{array}$ & $\begin{array}{l}\text { "A Comissão Nacional de Aids foi estabelecida em 1986. Isso foi } \\
\text { um logro importante e continua até hoje, eu diria que ela já foi } \\
\text { mais uma referência política do que é hoje, eu tenho a impressão } \\
\text { que perdeu um pouco o peso político. E também o nível técnico } \\
\text { de representatividade. [...] A Cnaidsfoi sempre uma referência } \\
\text { importante política e técnica. Eu acho que hoje, eu não sei, se a } \\
\text { Cnaids é mais política ou técnica, ou técnica e menos política não } \\
\text { sei, um detalhe que não tenho acompanhado. Até poderia estar } \\
\text { lá na Cnaids, mas quando eu voltei como diretor do programa em } \\
\text { 2004, a primeira coisa que fiz foi reformular a portaria e tirar a } \\
\text { Unaids da membresia, porque eu falei "não isso aqui é um corpo } \\
\text { nacional, é nacional não tem que ter agência sentada discutindo } \\
\text { coisas..." A agência pode ser convidada a opinar, a aportar algum } \\
\text { assunto, mas não como membro [...]. Eu acho que tem que ter } \\
\text { espaços específicos que tem que ser garantidos para preservar } \\
\text { a autonomia e inclusive a consistência, a sustentabilidade das } \\
\text { instituições nacionais." }\end{array}$ \\
\hline E28 & Burocrático & $\begin{array}{l}\text { Instância de assessoria técnica, } \\
\text { orientadora da política }\end{array}$ & $\begin{array}{l}\text { "Ela é orientadora mesmo, qualquer política nova, a gente não faz } \\
\text { nada se não mostrar primeiro na Cnaids." }\end{array}$ \\
\hline E33 & Militante & $\begin{array}{l}\text { Transformação em instância } \\
\text { inoperante na sua } 2^{\mathrm{a}} \text { fase }\end{array}$ & $\begin{array}{l}\text { "[...] Ela não conseguia influenciar mais as políticas de aids, não } \\
\text { se dava ouvidos e atenção ao que se propunha, e então a Abia } \\
\text { efetivamente resolve se afastar como uma maneira de denunciar } \\
\text { essa inoperância, vamos dizer assim, da comissão. Então, mas } \\
\text { também tinha o caso de estar muitos anos nesse tipo de comissão e } \\
\text { que isso... E também tinha que dar espaço para outras entrarem." }\end{array}$ \\
\hline
\end{tabular}




\section{APÊNDICE F Realização profissional e/ou militante}

\begin{tabular}{|c|c|}
\hline SE & Realização profissional/militante \\
\hline Burocrático & $\begin{array}{l}\text { "Me sinto realizado, me sinto copartícipe, eu me reconheço nesse processo. Mas acho que são sentimentos do } \\
\text { passado, porque do presente e pro futuro é uma certa inquietação." (E1) }\end{array}$ \\
\hline Burocrático & $\begin{array}{l}\text { "[...] eu acho que eu cumpri minha obrigação vamos dizer assim. Cumpri o meu dever profissional. Eu fiquei } \\
\text { muito satisfeita [...] E foi muito bom eu também ter participado disso porque foi quando eu tive contato com } \\
\text { grupos ativistas dos movimentos sociais, foi a primeira vez que profissionalmente eu comecei a lidar com } \\
\text { digamos a sociedade civil organizada dentro do sistema. [...] Para mim foi muito importante, fiz boas amizades } \\
\text { também do ponto de vista pessoal [...] apesar de toda confusão que era isso, nas reuniões de trabalho a gente } \\
\text { aprendia muito, a gente tinha possibilidade de conhecer as experiências e isso para mim profissionalmente, foi } \\
\text { muito importante." (E2) }\end{array}$ \\
\hline Militante & $\begin{array}{l}\text { "Realizada em termos. Mas sei que, aquela coisa, não é completo. Você sabe que dia a dia faltam mais coisas, } \\
\text { [...], você estando no meio você vê que falta isso, falta aquilo. } 0 \text { que atualmente me angustia é falta de...[...] } \\
\text { E eu não vejo uma pessoa... Eu estou com } 63 \text { anos e eu estou cansada [...] eu não tenho mais pique... Antes, ali } \\
\text { no carnaval por exemplo, em uma noite a gente desfilava em } 8,10 \text { escolas de samba. Ficava com o pé deste } \\
\text { tamanho, com a perna toda inchada mas no dia seguinte estava lá de novo. E hoje eu estou pensando, fazer o } \\
\text { quê? Por isso que eu estou amando esse pessoal jovem. E cada hora que chega, chega mais um, chega mais um, } \\
\text { então eles estão adorando isso. A minha esperança é que daí saia um ou dois. Porque não sai mais que isso." (E3) }\end{array}$ \\
\hline Científico & $\begin{array}{l}\text { "[...] eu me lembro perfeitamente que quando eu disse a minha mulher se ela queria casar comigo, mas que } \\
\text { ela iria ser pobre a vida toda, ela topou. E eu acho que eu não fiquei pobre, ao contrario, eu tive uma vida muito } \\
\text { rica porque as oportunidades que a pesquisa, a medicina me deram foi muito grande. De conhecer o mundo, } \\
\text { de participar de reuniões [...] eu acho que a aids deu essa oportunidade, mas eu acho que também pela própria } \\
\text { trajetória que eu tive antes da aids, eu acho que não teria talvez muita oportunidade. Eu acho que teria também } \\
\text { porque quando eu decidi, decidimos, não fui eu somente, fui eu e minha mulher, decidimos sair do país para ter } \\
\text { uma experiência fora, porque achávamos que era extremamente importante." (E4) }\end{array}$ \\
\hline $\begin{array}{l}\text { Militante/ } \\
\text { Burocrático }\end{array}$ & $\begin{array}{l}\text { "[...] acho que minha experiência no programa de aids foi a das melhores para mim, provavelmente, uma } \\
\text { grande experiência de trabalho e me sinto realizada, acho que eu fiz o melhor que eu pude e acho que eu deixei } \\
\text { muitas coisas lá de marca, de referência, não só as publicações, que eu tentei registrar alguma coisa, mas o } \\
\text { trabalho que a gente fez, por exemplo, com sustentabilidade que foi dois anos isso, eu acho que foi um trabalho } \\
\text { importante [...]" (E5) }\end{array}$ \\
\hline $\begin{array}{l}\text { Militante/ } \\
\text { Burocrático }\end{array}$ & $\begin{array}{l}\text { "[...] hoje essa militância, esse trabalho, acho que representa para minha vida pessoal representa uma } \\
\text { possibilidade de vida mesmo. Eu acho que eu não sei o que eu seria se eu não estivesse trabalhando nessa } \\
\text { questão. As vezes a gente trabalha demais até, mas trabalha contente, às vezes você briga, você faz, extrapola, } \\
\text { mas a gente faz exatamente porque a gente acredita na proposta do que está aí colocado." (E6) }\end{array}$ \\
\hline $\begin{array}{l}\text { Científico/ } \\
\text { Burocrático }\end{array}$ & $\begin{array}{l}\text { "Sentir realizado, eu não sei como responder isso, porque é um troço difícil. Mas eu faria tudo de novo, até } \\
\text { melhor um pouco, com mais experiência, mas eu não me arrependo não, sabe, eu passei maus momentos } \\
\text { respondendo aos inquéritos do TCU, pessoalmente, [...] isso foi muito ruim mesmo. Perdi dinheiro, tempo, } \\
\text { qualidade de vida, anos de vida. Eu que sempre procurei fazer as coisas corretas, aquilo foi muito difícil pra mim. } \\
\text { Mas, eu teria feito tudo de novo [...] a gente ter deixado isso, dando todos os remédios, organizado, um sistema } \\
\text { nacional, eu me sinto bem... Foi bom. Paguei um preço, mas, foi bom. [...] Me faz bem isso. Realmente foram } \\
\text { milhares de pessoas que não morreram. [...]" (E7) }\end{array}$ \\
\hline Militante & $\begin{array}{l}\text { "[...] eu acho que a gente tomou uma série de caminhos corretos. Eu acho que eu tenho um certo orgulho da } \\
\text { resposta brasileira à aids. E fico feliz por ter podido cooperar um pouco com isso. Mas a aids para mim é uma } \\
\text { grande tragédia, que assim, até hoje me dá vontade de chorar. Perdi muitos amigos e meu irmão." (E8) }\end{array}$ \\
\hline
\end{tabular}




\begin{tabular}{|c|c|}
\hline SE & Realização profissional/militante \\
\hline Burocrático & $\begin{array}{l}\text { "Eu trabalhei minha vida toda nisso. Nunca trabalhei no setor privado. [...] eu acho que eu procurei dar a minha } \\
\text { contribuição. Fiz o melhor que pude pelo menos. E só me dediquei a isso. Agora, se eu me sinto realizada? Não. } \\
\text { Queria o SUS implantado, atendendo a necessidade de saúde da população. Mas acho que está no caminho. } \\
\text { [...." (E10) }\end{array}$ \\
\hline $\begin{array}{l}\text { Militante/ } \\
\text { Burocrático }\end{array}$ & $\begin{array}{l}\text { - Você se sente realizado por ter militado na área de aids? } \\
\text { E12"- Com certeza." } \\
\text { - E trabalhando com aids? } \\
\text { E12"- Mais ainda. [...] Porque na militância, tu provoca, tu provoca, mas tu não faz. Aqui eu posso fazer." }\end{array}$ \\
\hline Burocrático & $\begin{array}{l}\text { "Eu gosto daqui [do Departamento Nacional de DST, aids e hepatites virais], acho que é um programa muito } \\
\text { importante de se trabalhar. [...] Gosto, me empenho como técnico, mas o meu trabalho sempre foi na área de } \\
\text { dermatologia. [...] Meu sonho sempre foi ver a eliminação da hanseníase. Não da forma que a OMS queria, por } \\
\text { isso que eu sai de lá. Mas eu gosto de trabalhar, sim. Acho que eu me empenho bastante. Acho que, depois } \\
\text { que eu cheguei aqui, a gente aumentou o leque das doenças de notificação compulsória. Principalmente, eu } \\
\text { gosto de trabalhar com doenças negligenciadas. [...] eu acho que tenho uma contribuição importante dentro do } \\
\text { ponto de vista da epidemiologia aqui." (E11) }\end{array}$ \\
\hline $\begin{array}{l}\text { Militante/ } \\
\text { Burocrático }\end{array}$ & $\begin{array}{l}\text { "Eu me sinto fazendo o que eu gosto, realizado, completamente realizado, às vezes. E eu quero continuar assim, } \\
\text { ainda quero continuar me indignando com algumas coisas, então, não totalmente realizado, mas eu acho que } \\
\text { nada melhor do que um dia após o outro, mas eu gosto muito do que faço, e procuro fazer com responsabilidade } \\
\text { [...." (E13) }\end{array}$ \\
\hline Militante & $\begin{array}{l}\text { "Sem dúvida eu não seria a pessoa que sou, se não tivesse feito minha trajetória de vida no enfrentamento à } \\
\text { epidemia de aids. [...] eu devo muito à causa da aids, a pessoa que sou, meus princípios, minha ética, minha } \\
\text { relação com a vida. [...] me sinto bem satisfeito pelo que fiz e que tenho feito pela causa da aids. Foi difíiil no } \\
\text { começo [...] Era um tema em que as pessoas não queriam se envolver. [...] Muitos pensam que eu me envolvi } \\
\text { porque eu era contaminado, que isso para mim não importa em nada, já que para mim, estar contaminado } \\
\text { ou não estar contaminado, somos todos iguais. [...] trabalhar com aids e que me trouxe muitos ensinamentos. } \\
\text { Ensinamentos que eu estou carregando para o resto da minha vida." (E14) }\end{array}$ \\
\hline Burocrático & $\begin{array}{l}\text { "Olha, como profissional sim, eu me sinto realizada [...], porque você acaba sendo um referencial aqui dentro. } \\
\text { Então, eu sou uma secretária... mas eu sou, para mim hoje, para o departamento, independente das pessoas } \\
\text { reconhecerem ou não, sou muito mais do que uma secretária, porque você acaba assessorando outras pessoas, } \\
\text { você acaba dando uma assessoria aos técnicos, aos diretores, aos que estão chegando, aos que estão indo, e que } \\
\text { aonde eles vão, eles acabam me ligando [...] Então, de aids, eu sei por onde a gente deve ir, os caminhos que a } \\
\text { gente deve começar, eu queria ter tido o êxito financeiro que tenho no êxito profissional mas não tive o êxito } \\
\text { financeiro. Ainda é minha grande luta. [...]" (E15) }\end{array}$ \\
\hline Científico & $\begin{array}{l}\text { "Completamente. Pra mim foi um grande aprendizado. Eu aprendo todo dia trabalhando com HIV/aids. Nunca } \\
\text { imaginei ir pra congressos internacionais onde você vê representações de toda sociedade civil organizada: de } \\
\text { travestis, de homossexuais, de você vê o governo de fato financiando a participação de mulheres profissionais } \\
\text { do sexo, [...] de termos jovens, ex-usuários e usuários de droga falando em um congresso de prevenção. Meu } \\
\text { colega de mesa era um jovem do Pará, dividiu a mesa comigo para falar da proteção de crianças com HIV/aids. } \\
\text { Então, isso é muito rico na nossa prática de pesquisa e na produção de conhecimento." (E16) }\end{array}$ \\
\hline Burocrático & $\begin{array}{l}\text { "Sim. Totalmente. Isso ai é uma coisa que me satisfaz muito tá lidando e trabalhando nesses diferentes } \\
\text { contextos, diferentes situações." (E17) }\end{array}$ \\
\hline $\begin{array}{l}\text { Científico/ } \\
\text { Burocrático }\end{array}$ & $\begin{array}{l}\text { "Foi umas das melhores experiências profissionais que eu tive. Até por conta do significado da pandemia, do } \\
\text { sucesso brasileiro em ter conseguido fazer um programa... Quer dizer, eu internacionalmente até faturo nisso, } \\
\text { quando me questionam do SUS, eu sempre menciono, o PNI, não é? E o Programa de Aids e anuncio que tive } \\
\text { presença ativa tanto em um como em outro. Enfim, foi uma das coisas que mais satisfação me deram na vida de } \\
\text { sanitarista." (E19) }\end{array}$ \\
\hline
\end{tabular}




\begin{tabular}{|c|c|}
\hline SE & Realização profissional/militante \\
\hline Militante & $\begin{array}{l}\text { "Na verdade, eu aos } 65 \text { anos, mais de } 30 \text { anos de militância pelos direitos humanos, seja com minorias } \\
\text { sexuais seja com DST/Aids, eu considero que o meu papel como pioneiro, muitas vezes, único interlocutor da } \\
\text { sociedade civil representando o movimento gay junto ao governo, eu tive um papel fundamental e já cumpri, } \\
\text { formando, capacitando inúmeras outras pessoas seja na área acadêmica onde eu consegui aprovar resoluções } \\
\text { seja na sociedade brasileira para o progresso da ciência, seja na associação brasileira de antropologia e outras } \\
\text { associaçóes acadêmicas, moções contra a discriminação aos portadores de HIV/aids, estimulando pesquisas } \\
\text { nessas áreas. [...] A minha contribuição foi, sobretudo nas duas primeiras décadas, minha e do GGB e Centro } \\
\text { Baiano Anti-AIDS." (E20) }\end{array}$ \\
\hline Militante & $\begin{array}{l}\text { "[...] eu acho que é muito difícil e tem horas que a gente se sente muito esgotada inclusive para a gente que } \\
\text { começou a muitos anos atrás e que não só militou mas teve que fazer com que essa organização se tornasse } \\
\text { essa referência que é nacional e até internacional, foram muitos anos de esforço, entre um pensamento e uma } \\
\text { prática organizativa, militante, profissional, então são diferentes articulações que você tem que fazer da sua } \\
\text { vida cotidiana e na sua prática profissional que as vezes são muito complexas, lidando com tudo isso, com } \\
\text { morte , com um monte de coisas, dores, escândalos, tudo isso, mas eu me sinto muito feliz [...]" (E22) }\end{array}$ \\
\hline Burocrático & $\begin{array}{l}\text { "Sim, porque na realidade são pessoas que de alguma forma ainda hoje sofrem preconceito. Então, quando elas } \\
\text { se sentem acolhidas, elas tem uma resposta muito positiva. } 0 \text { médico, hoje, ou a equipe de saúde que assiste } 0 \\
\text { paciente tem uma importância muito grande no sucesso mesmo da evolução do paciente." (E23) }\end{array}$ \\
\hline Científico & $\begin{array}{l}\text { "Eu me sinto realizado, acho que foi uma grande conquista do movimento. Um movimento que eu ajudei a criar. } \\
\text { Eu me sinto feliz porque a gente aprendeu que consegue mudar a opinião pública, a gente consegue sensibilizar } \\
\text { governo e os poderes para agir, desenvolver uma política de saúde para os usuários de drogas, estou vendo os } \\
\text { resultados agora de crimes homofóbicos [...]" (E25) }\end{array}$ \\
\hline Burocrático & $\begin{array}{l}\text { "Ah, sim, bastante. Na verdade acho que a vida tem várias etapas, acho que eu me sinto realizado quando eu } \\
\text { estava no serviç̧o de epidemiologia também. Foi muito gostoso. Acho que nós contribuímos um pouco. Demos } \\
\text { alguma contribuição para saúde pública, para epidemiologia fortalecendo os mecanismos que epidemiologia } \\
\text { usa como instrumental para existir na sua análise e tal. Eu acho que foi legal. E na aids também, acho que } \\
\text { minha contribuição não é a que deveria ter sido, mas a que foi possível pela limitação do contexto e a sua } \\
\text { própria limitação." (E27) }\end{array}$ \\
\hline Burocrático & $\begin{array}{l}\text { Ah, sim! [...] alguns lugares eu deixei de aceitar uma proposta justamente por que era uma coisa muito } \\
\text { comercial. [...] e você não tem essa possibilidade de saber, que, sei lá, alguma portaria que você faça aqui ou } \\
\text { algum sistema ou alguma coisa que você faça aqui vai interferir na vida de uma pessoa que tá lá na bancada, } \\
\text { que tá ali pegando seu medicamento, que tá precisando daquilo, se você conseguir tirar uma burocracia aqui, } \\
\text { você melhora, [...]. Se você conseguir deixar que ela saia do local dela, ande } 50 \text { km pra pegar um medicamento, } \\
\text { conseguir trazer um pouco mais perto dela, isso realiza muito mais do que comercialmente... (E28) }\end{array}$ \\
\hline Militante & $\begin{array}{l}\text { "[...] eu olho assim para essa história, como já faz muito tempo, e eu iniciei uma trajetória em outro campo } \\
\text { onde eu criei uma identidade muito forte, e tenho muitas realizações e tudo, eu olho para esse momento como } \\
\text { tendo sido uma missão cumprida." (E29) }\end{array}$ \\
\hline Científico & $\begin{array}{l}\text { "E me sinto bem confortável hoje, bem satisfeita com tudo que foi construído. Agora por ocasião desses } 30 \text { anos, } \\
\text { que a gente olha para trás, olha a história, vê que a gente fez parte de um movimento, de uma coisa nova, um } \\
\text { enfrentamento e consegui construir alguma coisa, é muito gratificante, muito estimulante também." (E30) }\end{array}$ \\
\hline Científico & $\begin{array}{l}\text { "Olha, acho que por causa disso eu acho que não. Eu tenho esse sentimento de realização com muita frequiência, } \\
\text { porque todos os objetivos que eu estabeleci, eu fui cumprindo e me sinto compensada neles. [...] eu acho } \\
\text { que eu fiz o meu dever, sabe? Não fiquei assim amedrontada, então já que esse negócio é perigoso, eu posso } \\
\text { me comprometer, [...] eu posso ser desvalorizada por isso. Então não aconteceu. [...] No dia que você fica } \\
\text { completamente realizada, vai sobrar o quê? Estou frustrada, todo dia estou frustrada. [...] Todo dia eu sinto } \\
\text { uma frustração, uma perda, uma sensação de que alguma coisa está precisando ser feita, de que eu não soube } \\
\text { fazer, de que eu precisava. Mas eu nem consigo saber direito o que é. Então eu não fiquei realizada. Porque eu } \\
\text { acho que se tiver que me sentir realizada, não sou eu. Eu acho que foi a política de obtenção de medicamento } \\
\text { independentemente do poder econômico. Isso sim. No dia que isso aconteceu pela primeira vez e que eu vi que } \\
\text { aquele sujeito, não ia precisar gastar mundos e fundos para salvar a própria vida, aí eu pensei'Puxa, o mundo } \\
\text { realmente está melhorando."' (E31) }\end{array}$ \\
\hline
\end{tabular}




\begin{tabular}{|c|c|}
\hline SE & Realização profissional/militante \\
\hline Científico & $\begin{array}{l}\text { "Muito, muito. [...] nós do Nepaids fizemos diferença nessa colaboração. Fizemos diferença. Produzimos teoria, } \\
\text { produzimos técnicas, produzimos práticas. Aprendemos com os erros, fomos interpelados pelos movimentos } \\
\text { sociais. Eas pessoas que trabalham com aids, por incrivel que pareça, que a desgraceira inicial é muito grande, } \\
\text { são pessoas que trabalham com muita alegria. É divertido. [...] a noção de solidariedade atravessa o trabalho } \\
\text { com aids, e ele funda o trabalho da resposta brasileira. Então essa noção da solidariedade acho que ajuda a } \\
\text { gente a celebrar cada vitória, celebrar memória de um jeito positivo, sem desfazer da memória, daqueles que a } \\
\text { gente perdeu..." (E32) }\end{array}$ \\
\hline Militante & $\begin{array}{l}\text { "Do ponto de vista profissional eu acho que sim, eu acho que nesses anos todos foram anos de completa } \\
\text { aprendizagem, eu nunca poderia ter visto o mundo como eu vi se não fosse a aids. Claro que a gente guarda } \\
\text { uma série de cicatrizes, eu estou cansado, não vou dizer que não, } 20 \text { poucos anos depois... [...] A gente também } \\
\text { vive uma questão, como a gente falou no início da entrevista, para quem trabalha com aids, é essa mistura } \\
\text { entre as nossas carreiras pessoais, profissionais, de saúde, tudo se mistura. Para quem é soropositivo, vira seu } \\
\text { trabalho, vira sua carreira profissional, é teu vírus, enfim... Para que trabalha com a questão é a tua profissão, é } \\
\text { a tua vida. Essa mistura tem um preço mas não deixa de trazer realizações." (E33) }\end{array}$ \\
\hline
\end{tabular}




\section{ANEXO A \\ Declaração dos direitos fundamentais do portador de HIV/aids ${ }^{136}$}

Rede Brasileira de Solidariedade (ONGs/AIDS) Porto Alegre, 1989

\section{Considerando}

que a AIDS, do ponto de vista de medicina, é uma doença como as outras; que a AIDS é uma epidemia mundial e é preciso um esforço coletivo mundial para detê-la;

que não existe perigo de contágio da AIDS exceto através das relações sexuais, de transfusão sanguínea e da passagem da mãe ao feto ou bebê; que do ponto de vista planetário é a Humanidade que se encontra soropositiva, não existindo uma "minoria" de doentes

que contra o pânico, os preconceitos e a discriminação a prática da solidariedade é essencial.

Proclamamos que:

I - Todas as pessoas têm direito à informação clara, exata, cientificamente fundada sobre a AIDS, sem nenhum tipo de restrição. Os portadores do vírus têm direito a informações específicas sobre sua condição.

II - Todo portador do vírus da aids tem direito à assistência e ao tratamento, dados sem qualquer restrição, garantindo sua melhor qualidade de vida.

III - Nenhum portador do vírus será submetido a isolamento, quarentena ou qualquer tipo de discriminação.

136 Documento aprovado durante o $1^{\circ}$ Encontro Nacional de ONG/Aids, realizado em Porto Alegre, em 10 outubro de 1989. Ver Rede Brasileira de Solidariedade (1989). 
IV - Ninguém tem o direito de restringir a liberdade ou os direitos das pessoas pelo único motivo de serem portadoras do HIV/aids, qualquer que seja sua raça, nacionalidade, religião, sexo ou orientação sexual.

$\mathrm{V}$ - Todo portador do vírus da aids tem direito à participação em todos os aspectos da vida social. Toda ação que visar a recusar aos portadores do HIV/aids um emprego, um alojamento, uma assistência ou a privá-los disso, ou que tenda a restringi-los à participação em atividades coletivas, escolares e militares, deve ser considerada discriminatória e ser punida por lei.

VI - Todas as pessoas têm direito de receber sangue e hemoderivados, órgãos ou tecidos que tenham sido rigorosamente testados para o HIV.

VII - Ninguém poderá fazer referência à doença de alguém, passada ou futura, ou ao resultado de seus testes para o HIV/aids, sem o consentimento da pessoa envolvida. A privacidade do portador do vírus deverá ser assegurada por todos os serviços médicos e assistenciais.

VIII - Ninguém será submetido aos testes de HIV/aids compulsoriamente, em caso algum. Os testes de aids deverão ser usados exclusivamente para fins diagnósticos, controle de transfusões e transplantes, estudos epidemiológicos e nunca qualquer tipo de controle de pessoas ou populações. Em todos os casos de testes, os interessados deverão ser informados. Os resultados deverão ser transmitidos por um profissional competente.

IX - Todo portador do vírus tem direito a comunicar apenas às pessoas que deseja seu estado de saúde e o resultado dos seus testes.

X - Toda pessoa com HIV/aids tem direito à continuação de sua vida civil, profissional, sexual e afetiva. Nenhuma ação poderá restringir seus direitos completos à cidadania.

VIVA A VIDA!

Rede Brasileira de Solidariedade (ONGs/AIDS)

Porto Alegre

Outubro de 1989 
- ABIA - Associação Brasileira Interdisciplinar de Aids (RJ)

- ALIA - Associação Londrinense Interdisciplinar de Aids (PR)

- ARCA - Apoio Religioso contra a AIDS (RJ)

- Associação de Voluntários do Hospital Emílio Ribas (SP)

- ATOBÁ - Movimento de Emancipação Homossexual (RJ)

- Centro de Controle e Investigação Imunológica Dr. Alfredo Corsini (SP)

- DIALOGUEI (SE)

- GAPA - Grupo de Apoio e Prevenção à AIDS

GAPA - Baixada Santista (SP)

GAPA - Belém (PA)

GAPA - Belo Horizonte (MG)

GAPA - Fortaleza (CE)

GAPA - Florianópolis (SC)

GAPA - Porto Alegre (RS)

GAPA - Recife (PE)

GAPA - Ribeirão Preto (SP)

GAPA - Rio de Janeiro (RJ)

GAPA - Salvador (BA)

GAPA - São Paulo (SP)

GAPA - Taubaté (SP)

- GETAIDS - Grupo de Estudos e Tratamento da AIDS (DF)

- GGB - Grupo Gay da Bahia (BA)

- Grupo Asa Branca (CE)

- Projeto Nomes - Coordenação Nacional

- Núcleo Santos (SP)

- Núcleo Salvador (BA)

- Núcleo Florianópolis (SC)

- Grupo Pela VIDDA (Pela Valorização, Integração e Dignidade do Doente de AIDS)

Pela VIDDA - RJ

Pela VIDDA - SP

Pela VIDDA - RS

- LAMBDA - Centro de Apoio ao Paciente com AIDS (SP)

- MAPA - Movimento de Apoio ao Paciente de AIDS (SP)

- PRADIS - Associação Evangélica de Apoio ao Paciente de AIDS e Familiares (SP)

- Programa Prostituição e Direitos Civis (RJ)

- Solidariedade (MG) 


\section{ANEXO B \\ Projeto de lei no ${ }^{\circ}$ 158, de 1996}

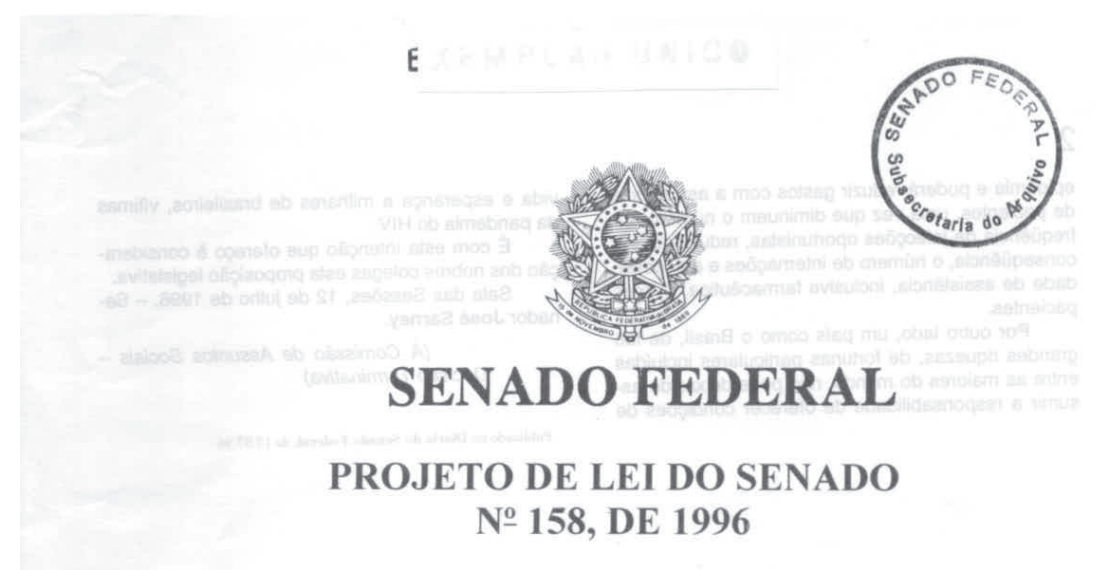

Dispōe sobre a distribuição gratuita de medicamentos aos portadores do HIV e doentes de Aids.

O Congresso Nacional decreta:

Art. $1^{2}$ Os portadores do HIV (vírus da imunodeficiência humana) e doentes de Aids (Síndrome da Imunodeficiência Adquirida) receberāo gratuitamente, do Sistema Único de Saúde, toda a medicação necessária a seu tratamento.

$\S 1^{\circ} \mathrm{O}$ Poder Executivo, através do Ministério da Saúde, padronizará os medicamentos a serem utilizados em cada estágio evolutivo da infecção e da doença, com vistas a orientar a aquisição dos mesmos pelos gestores do Sistema Único de Saúde.

$\S 2^{\circ} \mathrm{A}$ padronização deverá ser revista e republicada anualmente, para se adequar ao conhecimento cientifico atualizado e à disponibilidade de novos medicamentos no mercado.

Art. $2^{\circ}$ As despesas decorrentes da implementação desta Lei correrão à conta de dotação orçamentária própria do Ministério da Saúde e das oriundas da arrecadaçāo da Contribuiçāo Provisória sobre Movimentação Financeira.

Art. $3^{\circ}$ Esta Lei entra em vigor na data de sua publicação.

Art. $4^{\circ}$ Revogam-se as disposições em contrário. Justificação

Está na nossa Constituiçāo (art. 196) que a saúde é um direito de todos e que é dever do Estado garanti-la.

O acesso à assistência farmacêutica por parte de alguns grupos vulneráveis - como é o caso dos portadores do HIV e pacientes de Aids - é um dos elementos desse direito de cidadania que, apesar do dispositivo constitucional, nāo se concretizou integraimente.

As notícias que nos chegam da XI Conferência Internacional sobre Aids, realizada em Vancouver, no Canadá, sobre os novos esquemas terapêuticos para o tratamento da Aids, ao mesmo tempo em que oferecem esperanças para milhares de pessoas, trazem o desafio de encontrar meios para disponibilizar esses medicamentos para todus que deles necessitam, em razāo de seu custo elevado, tanto para pacientes individualmente como para os programas governamentais de controle e assistência à Aids.

Preocupados com a relevância de outros problemas de saúde, as autoriuades sanitárias podem considerar que esta não seja uma ação prioritária. A aprovação recente da Contribuição Provisória sobre Movimentações Financeiras aportará ao setor saúde recursos com os quais poderá fazer frente a essa nova despesa.

A proposição que apresento aos nobres colegas desta Casa visa, assim, nāo apenas a garantir a concretização do dispositivo constitucional como, também, ao cumprimento de um dever de humanidade para com os brasileiros acometidos pela Aids.

A adoçăo desses novos esquemas terapêuticos - que a imprensa passou a denominar "coquetel de drogas" ou "esquema tríplice", talvez influenciada pela denominação do esquema clássico de tratamento da tuberculose, utilizado por muitos anos deverá ter um impacto significativo na evolução da 
2 epidemia e poderá reduzir gastos com a assistência freqüência de infeccõos oportunistas, reduzindo, em conseqüência, o número de internaçōes e a necessidade de assistência, inclusive farmacêutica, desses pacientes.

Por outro lado, um país como o Brasil, de tão grandes riquezas, de fortunas particulares incluídas entre as maiores do mundo, não pode deixar de assumir a responsabilidade de oferecer condições de vida e esperança a milhares de brasileiros, vítimas da pandemia do HIV.

É com esta intenção que ofereço à consideração dos nobres colegas esta proposição legislativa.

Sala das Sessões, 12 de julho de 1996. - Senador José Sarney.

(À Comissão de Assuntos Sociais Decisão Terminativa)

Publicado no Diário do Senado Federal, de 13.07.96

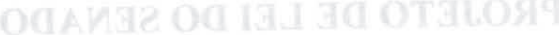

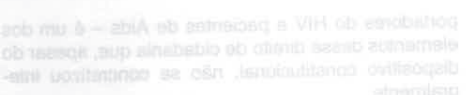

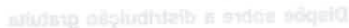

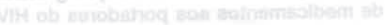
Qbila tab athingh

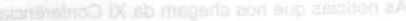

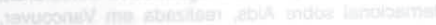

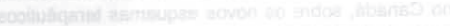

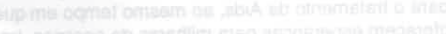

-

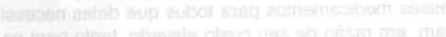

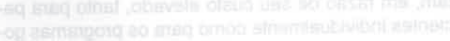

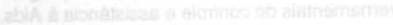

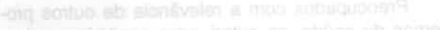

-

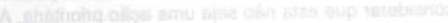

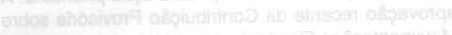

y

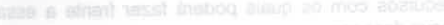

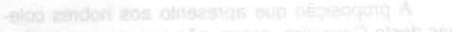

$-4$

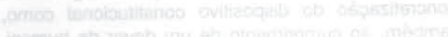

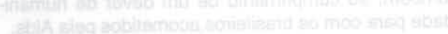

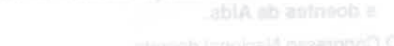

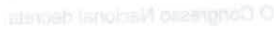

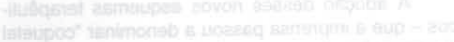
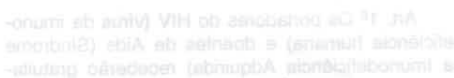

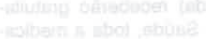
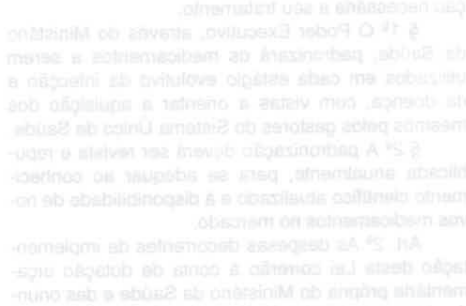

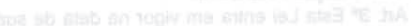

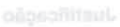

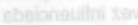

- 2 Centro Gráfico do Senado Federal - Brasilia - DF

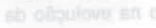




\section{ANEXO C \\ Discurso do presidente Fernando Collor de Melo em cadeia nacional de rádio e TV}

Leia o discurso do Presidente ${ }^{137}$

Esta é a integra do pronunciamento programado para ser apresentado ontem à noite, em cadeia de rádio e tv pelo presidente Collor.

Boa noite.

Hoje venho falar à família brasileira sobre um assunto de extrema importância par todos nós: a Aids.

O que pretendo como pai de família é informar o Senhor e a Senhora sobre essa doença que não tem cura, mas que pode ser prevenida.

Mas para isso, precisamos agir rapidamente para conter seu avanço, evitando dramáticas consequências.

Há uma guerra a ser vencida.

A Aids é uma emergência médica que justifica ações urgentes do governo em todos os níveis: não é uma doença que possa ser tratada com meias verdades ou meias medidas.

A falta de informação é o primeiro obstáculo que temos que vencer.

Nenhum brasileiro, rico ou pobre, velho ou moço, homem ou mulher, pode recusar-se, sob qualquer pretexto, a buscar informações sobre a questão.

Texto extraído da Folha de São Paulo, de $1^{\circ}$ de dezembro de 1991, Primeiro Caderno, seção Brasil, p. 4. O discurso foi distribuído na manhã do dia 30/11/1991 e o pronunciamento aconteceu à noite desse mesmo dia. O texto foi digitado exatamente como no original. A autora tentou localizar o referido pronunciamento na Biblioteca da Presidência da República, sem sucesso. 
Os primeiros casos de aids no Brasil apareceram no começo da década passada, com o registro de alguns poucos doentes em São Paulo e no Rio de Janeiro.

A partir de 1985, esses casos passaram a crescer de forma acelerada, como mostram essas colunas em vermelho.

Existem hoje, em todo o País, espalhados por 900 municípios, 21 mil casos de Aids.

Não se trata, vejam bem, de uma doença que só atinge as grandes cidades: é um problema que está crescendo no país inteiro.

O Ministério da Saúde estima que haja, atualmente, no País, entre 500 e 700 mil pessoas infectadas pelo vírus, o que indica um crescimento acelerado da doença na última década.

Isso não significa que esses milhares de infectados já tenham os sintomas e nem sequer saibam estar doentes.

O período de incubação da doença é de 9 anos em média: isso quer dizer que todas essas pessoas, que não têm qualquer sintoma, podem transmitir o vírus para os outros.

Pensem no que isso significa em perdas de vidas humanas.

Precisamos agir já, para evitar uma verdadeira tragédia.

Este gráfico é impressionante.

Vejam: ele indica a necessidade de agirmos, Governo e Sociedade, de forma urgente; porque se nada fizermos, no ano 2000 serão 8 milhões, repito 8 milhões o número de brasileiros infectados pela doença, se não houver campanha visando educar, adotar medidas de prevenção.

Mesmo assim é possível que cheguemos ao ano 2000 com dois milhões de doentes.

Como evitar isso?

É preciso saber que a doença é causada por um tipo de micróbio, um vírus, o HIV, o vírus da Aids, que destrói a capacidade do corpo de resistir a infecções comuns.

O vírus é transmitido da seguinte forma: por relações sexuais com pessoas infectadas, por agulhas e seringas contaminadas, por transfusões de sangue contaminado, e da mulher infectada ao recém-nascido, durante a gravidez ou o parto. 
Essas são as formas de transmissão reconhecidas pela ciência.

Felizmente não se transmite no trabalho, nas escolas, no ônibus, trem, metrô ou outros tipos de transportes.

Não se transmite pelo aperto de mão, pelo abraço, pela convivência normal nas casas; não se transmite em banheiros, piscinas, pela mordida de insetos, nem pela comida.

Sobretudo, não se transmite pela solidariedade, pelo amor e carinho ao próximo.

Minha gente,

Temos que lutar contra o preconceito e contra a discriminação aos doentes de Aids.

Primeiro, porque esta é uma atitude cristã que nos deve guiar.

Segundo, porque há hoje 10 milhões de portadores do vírus em todo o mundo, e centenas de pessoas contraem a doença diariamente, o que em menos de uma década fará com que todos nós conheçamos alguém de nosso círculo mais íntimo de relacionamento contaminado como vírus, caso não sejam tomadas as medidas preventivas necessárias.

Terceiro, porque o portador da Aids está perfeitamente habilitado a exercer a maioria das profissões, sem oferecer risco ao próximo.

Quarto, porque a ignorância é a única justificativa para a discriminação e o preconceito.

Estigmatizar os portadores da doença apenas agrava o profundo drama que vivem essas pessoas, que merecem a nossa compreensão e sobretudo solidariedade.

Relembro as sábias palavras do Evangelho: "Felizes os que têm misericórdia dos outros, pois Deus terá misericórdia deles também".

Há poucos dias um grande jogador de basquete norte-americano veio a público para revelar a sua condição de portador do vírus.

Vários brasileiros têm agido da mesma forma.

Essas atitudes demonstram coragem heróica, despertando a atenção do mundo para um fato de extrema importância: a Aids não é uma doença que atinge os chamados grupos de risco, como erroneamente têm pensado algumas pessoas.

Ninguém que tenha vida sexualmente ativa está livre do risco da doença. 
Hoje, segundo dados da Organização Mundial de Saúde, 75\% dos portadores do vírus da Aids, no mundo, são heterossexuais.

Este gráfico nos mostra como isso vem acontecendo.

Em 1985, quando a incidência da doença começava a crescer mais aceleradamente no Brasil, 60\% das vítimas eram homossexuais.

Hoje são pouco mais de $40 \%$.

A série em vermelho mostra que também o número de bissexuais que contraíram a doença vem diminuindo.

Pensem nisso com cuidado!

Há outro dado fundamental: o aumento de casos por uso de drogas é assustador.

De 1980 a 1986, apenas 3\% dos casos no Brasil eram relacionados com usos de drogas injetáveis.

Vejam vocês nete gráfico que a partir de 1986 a Aids passou a contaminar mais e mais pessoas que fizeram o uso dessas drogas.

Esse número em 1991, subiu para 29\%.

O pior, o maior crescimento desse tipo de contaminação no Brasil ocorreu em adolescentes, na população de 13 a 19 anos de idade.

Como sabemos, ainda não há cura, mas a epidemia é evitável, porque sabemos a causa da doença: a transmissão do vírus HIV.

Ouçam com atenção as maneiras de prevenir a doença; ouçam e transmitam esses conselhos a seus amigos, amigos, filhos, filhas e parentes.

Você está se prevenindo contra a Aids:

- se não trocar de parceiros sexuais com frequencia e se tiver um relacionamento sexual seguro;

- se exigir teste anti-Aids nos bancos de sangue: saiba que a doação em locais apropriados é segura e um ato de amor ao próximo;

- se exigir agulhas e seringas descartáveis ou esterilizadas em farmácias, hospitais, postos de saúde e laboratório, bem como material esterilizado nos dentistas;

- se exigir, em cabelereiros, barbeiros, casas de tatuagem e acupuntura, esterilização dos objetos que cortam ou perfuram, como agulhas, alicates, giletes, navalhas. 
Vejam como tomando providências muito simples, você pode se ajudar a evitar o pior, porque cuidando de si próprio, você estará cuidando também do seu próximo.

Minha gente,

Apenas listar as maneiras de previnir não basta.

Precisamos ir mais além: pertenço a uma geração que prefere encarar os problemas de frente, sem moralismos falsos ou intolerâncias inaceitáveis para com o comportamento alheio.

A liberdade indivudual de agir é uma das maiores conquistas da civilização a que pertencemos, e de modo algum podemos usar a Aids como um pretexto para tolher ou qualificar a liberdade das pessoas.

Mas é preciso também fazer uma ressalva: a liberdade, nas sociedades modernas e justas, não existe dissociada de deveres e obrigações de parte de cada cidadão.

A liberdade tem que estar associada à idéia de responsabilidade, de respeito e, principalmente, de amor ao próximo.

Esses são valores universalmente aceitos.

E esses valores são tanto mais importantes quando tratamos da liberdade sexual: a promiscuidade é uma forma de comportamento que atenta para a própria vida; assim silenciar sobre o tema, por mais polêmico que possa ser, seria contraproducente.

Quando tratamos dessas questões que pertencem ao campo da moral, não estamos falando de algo que possa ser identificado como a moda, ou que possa ser considerado ultrapassado.

É preciso que todos se conscientizem da importância de se tratar a sexualidade humana, uma das mais belas e profundas manifestações da vida, com respeito e reponsabilidade.

Respeito e responsabilidade que são ainda maiores quando há uma epidemia que tem causado tanta dor, tantas perdas.

Minha gente,

Como pai de dois adolescentes e como Presidente da República, cumpro um dever inadiável em alertar a Nação e de liderar uma ampla campanha ampla, objetiva e corajosa de combate à Aids.

O Governo, consciente da sua obrigação moral e dever cívico, precisa agir rapidamente, combatendo a epidemia em várias frentes. 
Assim, estamos iniciando uma nova fase de trabalho em prevenção e assistência.

Já existe um amplo programa de distribuição de medicamentos, incluindo o AZT, que está sendo implementado pelo Ministério da Saúde.

Mas o principal papel do Governo é o de ajudar a prevenir a doença.

Estou determinado a constituição de uma Comissão Nacional de Aids, presidida pelo senhor Edson Arantes do Nascimento, o Pelé, que vai procurar mobilizar a sociedade para essa importante missão de combate à epidemia.

O Ministério da Saúde já está implantando um grande programa de descentralização do combate à doença, com a criação de programas municipais em 3.000 cidades brasileiras.

Em cada uma dessas cidades estão sendo criadas Comissões específicas, coordenadas pelas Secretarias Municipais de Saúde.

Esse esforço, porém, não será completo sem a mobilização de todos os cidadãos, das igrejas, escolas, empresas, sindicatos, associações comerciais, profissionais de saúde, organizações não governamentais, enfim, qualquer pessoa ou grupo que queira dedicar-se a essa tarefa.

O Senhor e a Senhora que estão assistindo a este pronunciamento ajudem a criá-la junto aos Prefeitos de suas cidades, ou procurem engajar-se no trabalho que já está sendo feito nas localidades onde morem.

Não podemos perder tempo.

Amanhã, um programa sobre esse tema e sobre o Programa de Descentralização do combate à Aids será levado ao ar em rede nacional de televisão e rádio.

É preciso que todos os brasileiros se engajem nessa luta: se falharmos, não poderemos culpar ninguém por nossa omissão, a senão a nós mesmos.

Lembre-se: pode acontecer com qualquer pessoa; não acredite nessa história do "comigo não acontece".

Há uma guerra a ser vencida.

Vamos vencê-la, minha gente, com a ajuda e o empenho de todos e de cada um dos brasileiros, e, acima de tudo, com a ajuda de Deus. Boa noite. 
9

Este livro foi publicado no formato $17 \times 24 \mathrm{~cm}$ utilizando as fontes Freight e Myriad Pro Miolo em papel Off-Set $90 \mathrm{~g} / \mathrm{m}^{2}$

Capa em Cartão Duo Design $300 \mathrm{~g} / \mathrm{m}^{2}$ Impresso na Gráfica Santa Marta, na Paraíba

500 exemplares 